\title{
Catalog of Earthquake Hypocenters at Alaskan Volcanoes: January 1 through December 31, 2009
}

Data Series 531 



\section{Catalog of Earthquake Hypocenters at Alaskan Volcanoes: January 1 through December 31, 2009}

By James P. Dixon, U.S. Geological Survey, Scott D. Stihler, University of Alaska Fairbanks, John A. Power, U.S. Geological Survey, and Cheryl K. Searcy, U.S.

Geological Survey

Data Series 531 


\section{U.S. Department of the Interior \\ KEN SALAZAR, Secretary \\ U.S. Geological Survey \\ Marcia K. McNutt, Director}

\section{U.S. Geological Survey, Reston, Virginia: 2010}

For more information on the USGS - the Federal source for science about the Earth, its natural and living resources, natural hazards, and the environment, visit http://www.usgs.gov or call 1-888-ASK-USGS.

For an overview of USGS information products, including maps, imagery, and publications, visit http://www.usgs.gov/pubprod

To order this and other USGS information products, visit http://store.usgs.gov

Any use of trade, product, or firm names is for descriptive purposes only and does not imply endorsement by the U.S. Government.

Although this report is in the public domain, permission must be secured from the individual copyright owners to reproduce any copyrighted materials contained within this report.

Suggested citation:

Dixon, J.P., Stihler, S.D., Power, J.A., and Searcy, Cheryl, 2010, Catalog of earthquake hypocenters at Alaskan volcanoes: January 1 through December 31, 2009: U.S. Geological Survey Data Series 531, 84 p. 


\section{Contents}

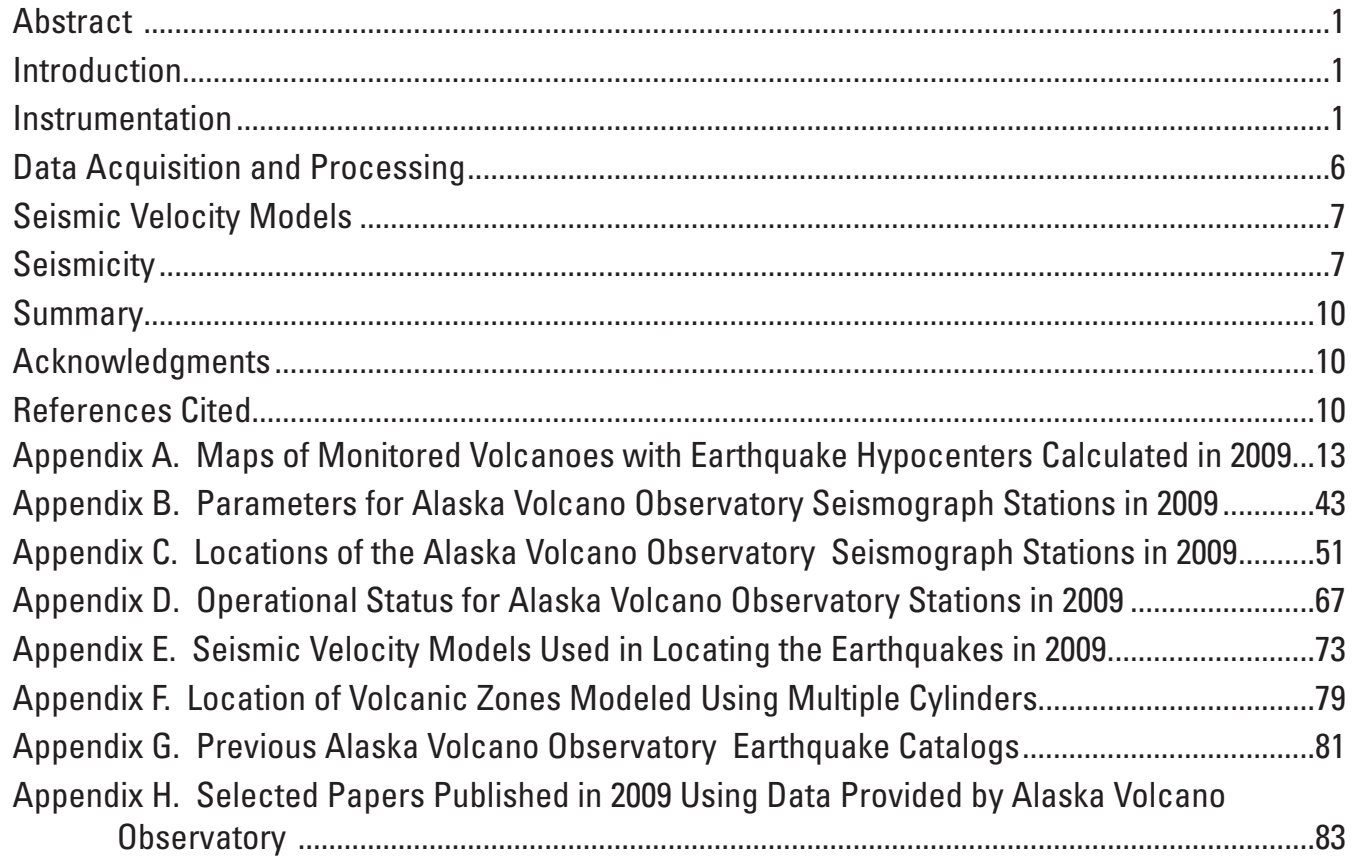

\section{Figures}

Figure 1. Map showing location of volcanoes mentioned in this report $\ldots \ldots \ldots \ldots \ldots \ldots \ldots .2$

Figure 2. Graph showing number of AVO seismograph stations by type and year. ......... 4

Figure 3. Log-log plot of representative displacement response curves for AVO short-period stations using a L4 (black), S13 (red), or L22 (green) seismometer $\ldots \quad 5$

Figure 4. Log-log plot of representative displacement response curves for the AVO broadband stations using a CMG-6TD (black) or CMG-40T (red) seismometer ..... 5

Figure 5. Graph showing number of earthquakes located per year in the AVO catalog (black line) and number of monitored volcanoes per year (green bars)

\section{Tables}

Table 1. Number of permanent AVO seismograph stations by type and network in $2009 \quad \ldots \quad 3$

Table 2. Number of Alaska Volcano Observatory seismograph stations by type and year ... 4

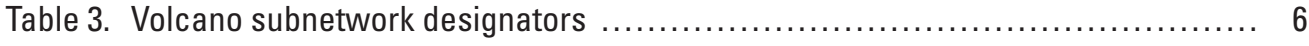

Table 4. Alaska Volcano Observatory event description codes ........................ 6

Table 5. Number of earthquakes located for each seismograph subnetwork in 2009 within $20 \mathrm{~km}$ of the volcanic centers in each subnetwork $\ldots \ldots \ldots \ldots \ldots \ldots \ldots . \ldots$

Table 6. Number of earthquakes located per year in the Alaska Volcano Observatory earthquake catalog 


\section{Conversion Factors and Datum}

Conversion Factors

\begin{tabular}{lll}
\hline Multiply & By & To obtain \\
\hline kilometer $(\mathrm{km})$ & 0.6214 & mile $(\mathrm{mi})$ \\
meter $(\mathrm{m})$ & 3.281 & foot $(\mathrm{ft})$ \\
\hline
\end{tabular}

Datum

Horizontal coordinate information is referenced to North American Datum of 1927 (NAD 27). 


\title{
Catalog of Earthquake Hypocenters at Alaskan Volcanoes: January 1 through December 31, 2009
}

\author{
By James P. Dixon ${ }^{1}$, Scott D. Stihler ${ }^{2}$, John A. Power ${ }^{3}$, and Cheryl Searcy ${ }^{3}$
}

\section{Abstract}

Between January 1 and December 31, 2009, the Alaska Volcano Observatory (AVO) located 8,829 earthquakes, of which 7,438 occurred within 20 kilometers of the 33 volcanoes with seismograph subnetworks. Monitoring highlights in 2009 include the eruption of Redoubt Volcano, as well as unrest at Okmok Caldera, Shishaldin Volcano, and Mount Veniaminof. Additionally severe seismograph subnetwork outages resulted in four volcanoes (Aniakchak, Fourpeaked, Korovin, and Veniaminof) being removed from the formal list of monitored volcanoes in late 2009. This catalog includes descriptions of: (1) locations of seismic instrumentation deployed during 2009; (2) earthquake detection, recording, analysis, and data archival systems; (3) seismic velocity models used for earthquake locations; (4) a summary of earthquakes located in 2009; and (5) an accompanying UNIX tar-file with a summary of earthquake origin times, hypocenters, magnitudes, phase arrival times, location quality statistics, daily station usage statistics, all files used to determine the earthquake locations in 2009, and a dataless SEED volume for the AVO seismograph network.

\section{Introduction}

The Alaska Volcano Observatory (AVO), established in 1988 as a cooperative program of the U.S. Geological Survey, the Geophysical Institute at the University of Alaska Fairbanks, and the Alaska Division of Geological and Geophysical Surveys, monitors historically active volcanoes in Alaska (fig. 1). The primary objectives of the AVO seismic program are the real-time seismic monitoring of active, potentially hazardous, Alaskan volcanoes and the investigation of seismic processes associated with active volcanism.
This catalog describes the location of seismic instrumentation deployed in the field, the earthquake detection, recording, analysis, and data archival systems, the seismic velocity models used for earthquake locations, and a summary of earthquakes located in 2009. A summary of earthquake origin times, hypocenters, magnitudes, phase arrival times, location quality statistics, daily station usage statistics, all files used to determine the earthquake locations in 2009, and a dataless SEED volume for the AVO seismograph network are included in a data supplement to this report.

\section{Instrumentation}

The permanent AVO seismograph network is composed of 24 subnetworks each with 4 to 20 seismograph stations and 10 regional seismograph stations for a total of 197 stations (tables 1 and 2; fig. 2). Three seismograph stations, all in the Redoubt subnetwork, were added to the AVO seismograph networks in 2009. Two were installed with a broadband sensor (RDJH and RDWB) and a third was installed with a short-period sensor by Drift River (RDDR). The Drift River seismograph station was initially installed in February and named RDE. In the following July, the station was moved and subsequently renamed RDDR. In addition to the permanent network, temporary broadband stations were set up in the Katmai Volcanic Cluster and on Kasatochi Volcano.

Six volcanoes out of the 33 volcanic centers with seismograph networks were not on the formal list of permanently monitored volcanoes in the AVO weekly update at the end of 2009. To be included in the list of monitored volcanoes in the AVO weekly update, the seismic subnetwork on the volcano must be in place long enough so that the background seismicity is known and have no prolonged station outages that prevent AVO from locating earthquakes.

\footnotetext{
${ }^{1}$ U.S. Geological Survey, Volcano Science Center, 903 Koyukuk Drive, Fairbanks, AK 99775

${ }^{2}$ University of Alaska Fairbanks, Geophysical Institute, 903 Koyukuk Drive, Fairbanks, AK 99775

${ }^{3}$ U. S. Geological Survey, Volcano Science Center, 4210 University Drive, Anchorage, AK 99508
} 


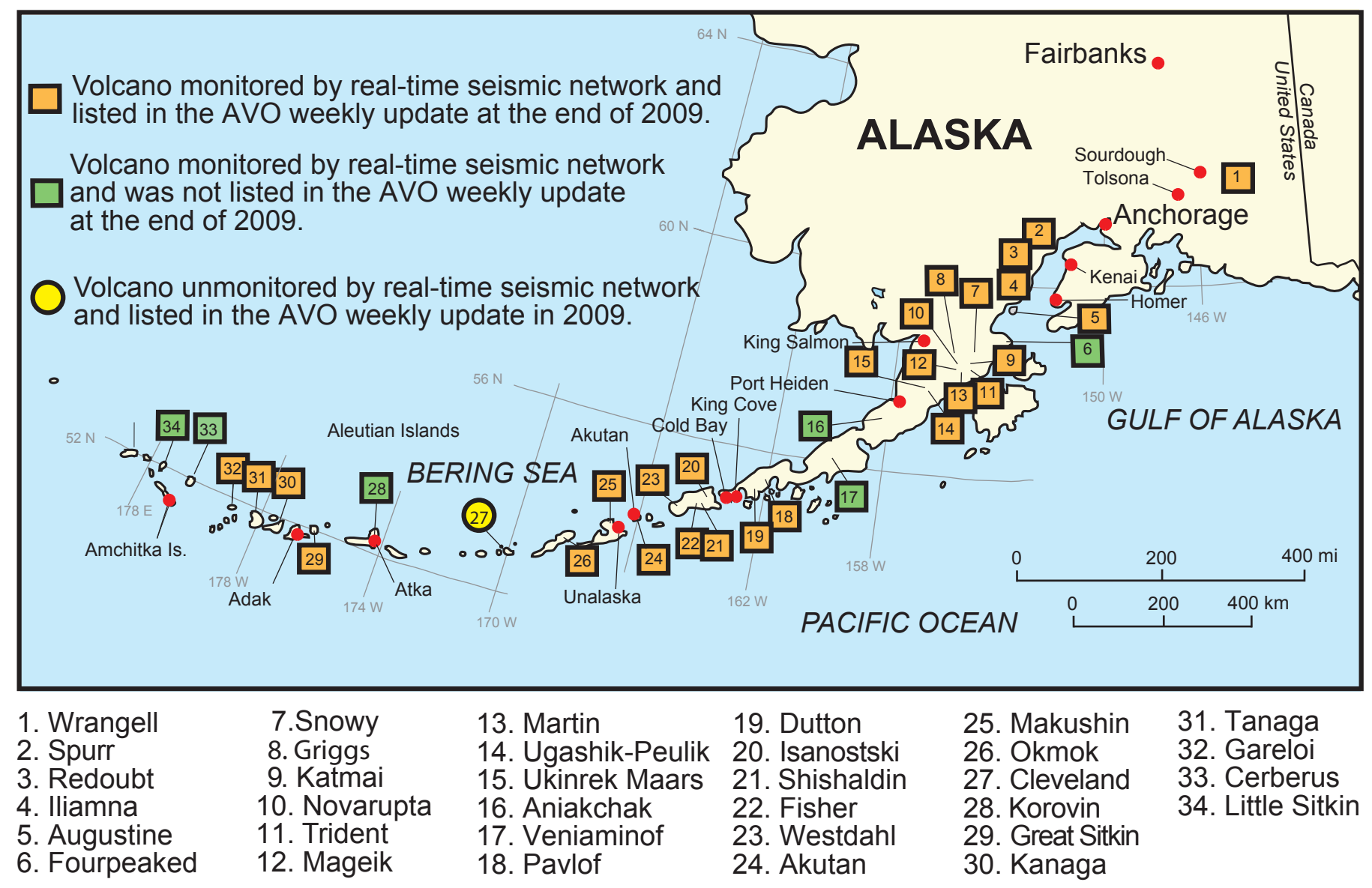

Figure 1. Location of volcanoes mentioned in this report. Red dots show locations that are referred to in this report.

Loss of data due to telemetry failures since their installation has prevented Little Sitkin and Mount Cerberus, the active vent on Semisopochnoi Island, from being added to list of permanently monitored volcanoes. Four volcanoes: Aniakchak, Fourpeaked, Korovin, and Veniaminof were delisted on November 17, 2009. AVO could no longer seismically monitor these volcanic centers because of seismograph station outages and as such were designated as being unassigned with respect to their Volcano Alert Level.

The 154 single-component short-period seismograph stations were equipped with either Mark Products L4 or Teledyne-Geotech S13 seismometers with a natural period of $1 \mathrm{~Hz}$. AVO also operated 22 three-component, short-period instruments during 2009. The instruments used at sites with three component sensors were either Mark Products L22, L4, or S13 seismometers. The L22 seismometer has a natural period of $2 \mathrm{~Hz}$. Nineteen broadband stations were operated with either a Guralp CMG-40T seismometer (frequency range: 0.033-50 Hz), Guralp CMG-6TD seismometer (frequency range: $0.033-50 \mathrm{~Hz}$ ), or Nanametrics Trillium 40 seismometer (frequency range: $0.025-50 \mathrm{~Hz}$ ). The Augustine strong motion station (AU22) used a REFTEK 130-ANSS/02 strong motion sensor (frequency range: $\mathrm{DC}-500 \mathrm{~Hz}$ ).
The majority of the short-period stations were digitized at 100 samples per second (sps). The Cerberus and Little Sitkin subnetworks were recorded at $50 \mathrm{sps}$ due to limitations in data rates using very small aperture terminal telemetry between the recording hub located on Amchitka Island and Anchorage. Broadband stations were digitized at 50 sps with the exception of AUL, which is recorded at 100 sps. Each seismograph station is individually set to record above the noise level at each site and the range of calibration curves for short-period and broadband seismometers used in the AVO network are shown in figures 3 and 4 . Calibration information for each station is found in a dataless SEED volume included in a data supplement to this report.

Data from short-period seismograph stations were telemetered using voltage-controlled oscillators (VCOs) to transform the signals generated by the seismometer (in response to ground velocity) from a voltage to a frequencymodulated carrier suitable for transmission over a radio link or telephone circuit. AVO used VCOs developed by McChesney (1999) to modulate signals in the field with one exception. Seismograph station NCG used an A1VCO, which is expected to be replaced when possible. Signals were transmitted via UHF and VHF radio to communication hubs located in Adak, 
Table 1. Number of permanent AVO seismograph stations by type and network in 2009.

\begin{tabular}{|c|c|c|c|c|c|c|}
\hline Subnetwork & $\begin{array}{c}\text { Number of } \\
\text { seismograph } \\
\text { stations in each } \\
\text { subnetwork }\end{array}$ & $\begin{array}{c}\text { Number } \\
\text { of station } \\
\text { components } \\
\text { in each } \\
\text { subnetwork }\end{array}$ & $\begin{array}{c}\text { Number } \\
\text { of single- } \\
\text { component } \\
\text { short-period } \\
\text { stations }\end{array}$ & $\begin{array}{c}\text { Number } \\
\text { of three- } \\
\text { component } \\
\text { short-period } \\
\text { stations }\end{array}$ & $\begin{array}{l}\text { Number } \\
\text { of three- } \\
\text { component } \\
\text { broadband } \\
\text { stations }\end{array}$ & $\begin{array}{c}\text { Number } \\
\text { of three- } \\
\text { component } \\
\text { strong motion } \\
\text { stations }\end{array}$ \\
\hline Akutan & 12 & 26 & 5 & 1 & 6 & 0 \\
\hline Aniakchak & 6 & 8 & 5 & 1 & 0 & 0 \\
\hline Augustine & 9 & 18 & 6 & 1 & 1 & 1 \\
\hline Cerberus & 6 & 8 & 5 & 1 & 0 & 0 \\
\hline Dutton & 5 & 5 & 5 & 0 & 0 & 0 \\
\hline Fourpeaked & 4 & 7 & 4 & 0 & 0 & 0 \\
\hline Gareloi & 6 & 8 & 5 & 1 & 0 & 0 \\
\hline Great Sitkin & 6 & 8 & 5 & 1 & 0 & 0 \\
\hline Iliamna & 6 & 8 & 5 & 1 & 0 & 0 \\
\hline Kanaga & 6 & 6 & 6 & 0 & 0 & 0 \\
\hline Katmai & 20 & 30 & 15 & 3 & 2 & 0 \\
\hline Korovin & 7 & 9 & 6 & 1 & 0 & 0 \\
\hline Little Sitkin & 4 & 6 & 3 & 1 & 0 & 0 \\
\hline Makushin & 7 & 9 & 6 & 1 & 0 & 0 \\
\hline Okmok & 12 & 18 & 9 & 0 & 3 & 0 \\
\hline Pavlof & 7 & 9 & 6 & 1 & 0 & 0 \\
\hline Peulik & 7 & 9 & 6 & 1 & 0 & 0 \\
\hline Redoubt & 10 & 19 & 6 & 2 & 2 & 0 \\
\hline Regional & 11 & 15 & 9 & 0 & 1 & 0 \\
\hline Shishaldin & 7 & 11 & 5 & 1 & 1 & 0 \\
\hline Spurr & 15 & 23 & 11 & 1 & 3 & 0 \\
\hline Tanaga & 6 & 8 & 5 & 1 & 0 & 0 \\
\hline Veniaminof & 9 & 9 & 9 & 0 & 0 & 0 \\
\hline Westdahl & 6 & 8 & 5 & 1 & 0 & 0 \\
\hline Wrangell & 4 & 6 & 3 & 1 & 0 & 0 \\
\hline Totals & 197 & 291 & 155 & 22 & 19 & 1 \\
\hline
\end{tabular}

Akutan, Amchitka Island, Anchorage, Atka, Cold Bay, Homer, Kenai, King Cove, King Salmon, Port Heiden, Sourdough, Tolsona, and Unalaska (fig. 1). Data were then digitized at the Adak, Amchitka Island, Homer, Kenai, King Salmon, and Unalaska communication hubs and directed to AVO offices via high-speed digital circuits. From all other hubs (Akutan, Cold Bay, Port Heiden, Sourdough, and Tolsona), analog signals were relayed via leased telephone circuits to AVO offices in Anchorage or Fairbanks where the signals were subsequently digitized. Data from broadband seismograph stations were digitized at the station site and transmitted digitally using spread spectrum radios to communication hubs in Akutan,
Anchorage, Homer, and King Salmon, and Unalaska. These data were forwarded to AVO offices in Fairbanks and Anchorage via high-speed digital circuits.

Earthquakes located in 2009 with the AVO seismograph network are shown in appendix A. Locations and descriptions for all AVO stations operated during 2009 are contained in appendix B. Maps showing the locations of stations with respect to individual volcanoes are contained in appendix C. Estimates of each station's operational status for the catalog period are shown in appendix D. Other station information are available as part of the data supplement to this report. 
Table 2. Number of Alaska Volcano Observatory seismograph stations by type and year.

\begin{tabular}{ccccccc}
\hline Year & $\begin{array}{c}\text { Number of } \\
\text { stations in } \\
\text { the AV0 } \\
\text { seismograph } \\
\text { network }\end{array}$ & $\begin{array}{c}\text { Number of } \\
\text { components } \\
\text { in the AV0 } \\
\text { seismograph } \\
\text { network }\end{array}$ & $\begin{array}{c}\text { Number } \\
\text { of single- } \\
\text { component } \\
\text { short-period } \\
\text { stations }\end{array}$ & $\begin{array}{c}\text { Number } \\
\text { of three- } \\
\text { component } \\
\text { short-period } \\
\text { stations }\end{array}$ & $\begin{array}{c}\text { Number } \\
\text { of three- } \\
\text { component } \\
\text { broadband } \\
\text { stations }\end{array}$ & $\begin{array}{c}\text { Number } \\
\text { of three- } \\
\text { component } \\
\text { strong motion } \\
\text { stations }\end{array}$ \\
\hline 1988 & 25 & 29 & 23 & 2 & 0 & 0 \\
1989 & 28 & 32 & 26 & 2 & 0 & 0 \\
1990 & 42 & 49 & 39 & 3 & 0 & 0 \\
1991 & 36 & 42 & 33 & 3 & 0 & 0 \\
1992 & 39 & 46 & 36 & 3 & 0 & 0 \\
1993 & 44 & 51 & 41 & 3 & 0 & 0 \\
1994 & 47 & 58 & 42 & 5 & 0 & 0 \\
1995 & 57 & 67 & 52 & 5 & 0 & 0 \\
1996 & 60 & 79 & 49 & 10 & 1 & 0 \\
1997 & 96 & 125 & 83 & 12 & 2 & 0 \\
1998 & 109 & 142 & 94 & 14 & 2 & 0 \\
1999 & 122 & 156 & 106 & 14 & 2 & 0 \\
2000 & 126 & 162 & 108 & 16 & 2 & 0 \\
2001 & 139 & 177 & 120 & 17 & 3 & 0 \\
2002 & 141 & 179 & 124 & 16 & 2 & 0 \\
2003 & 161 & 217 & 135 & 18 & 9 & 0 \\
2004 & 183 & 255 & 149 & 20 & 15 & 0 \\
2005 & 189 & 266 & 151 & 23 & 15 & 0 \\
2006 & 191 & 275 & 154 & 23 & 15 & 1 \\
2007 & 194 & 281 & 154 & 22 & 17 & 1 \\
2008 & 194 & 281 & 154 & 22 & 17 & 1 \\
2009 & 197 & 288 & 155 & 22 & 19 & 1 \\
\hline
\end{tabular}

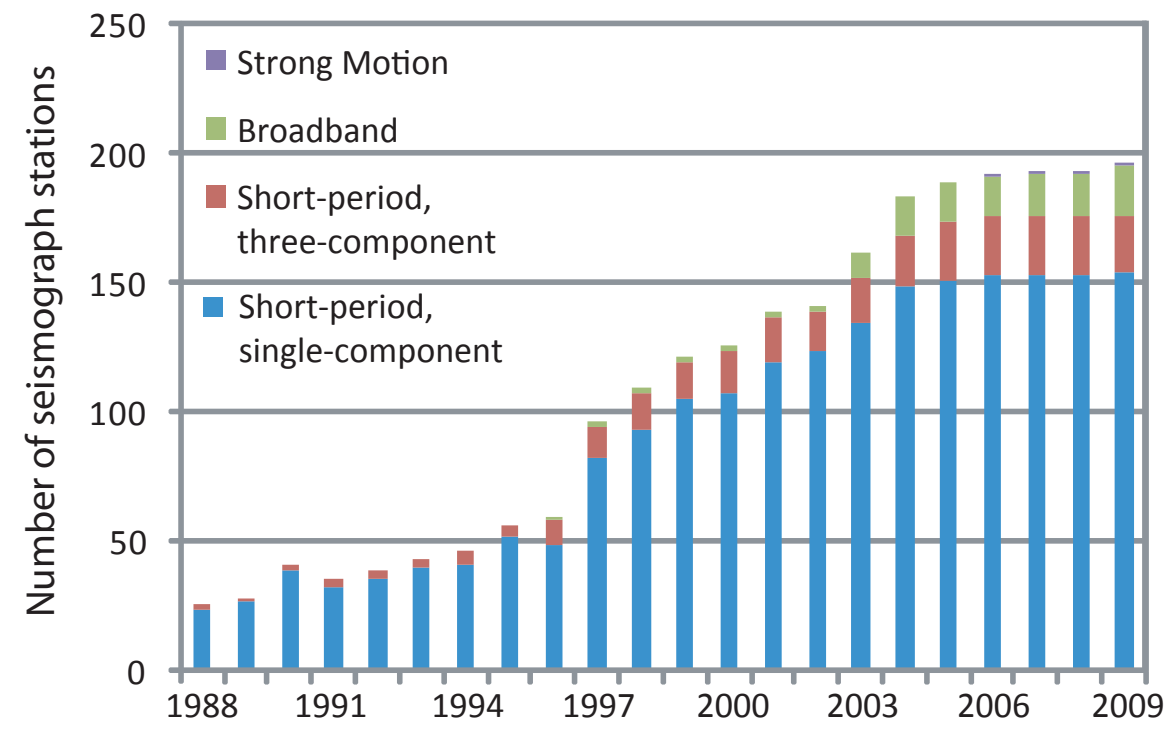

Figure 2. Number of AVO seismograph stations by type and year. 


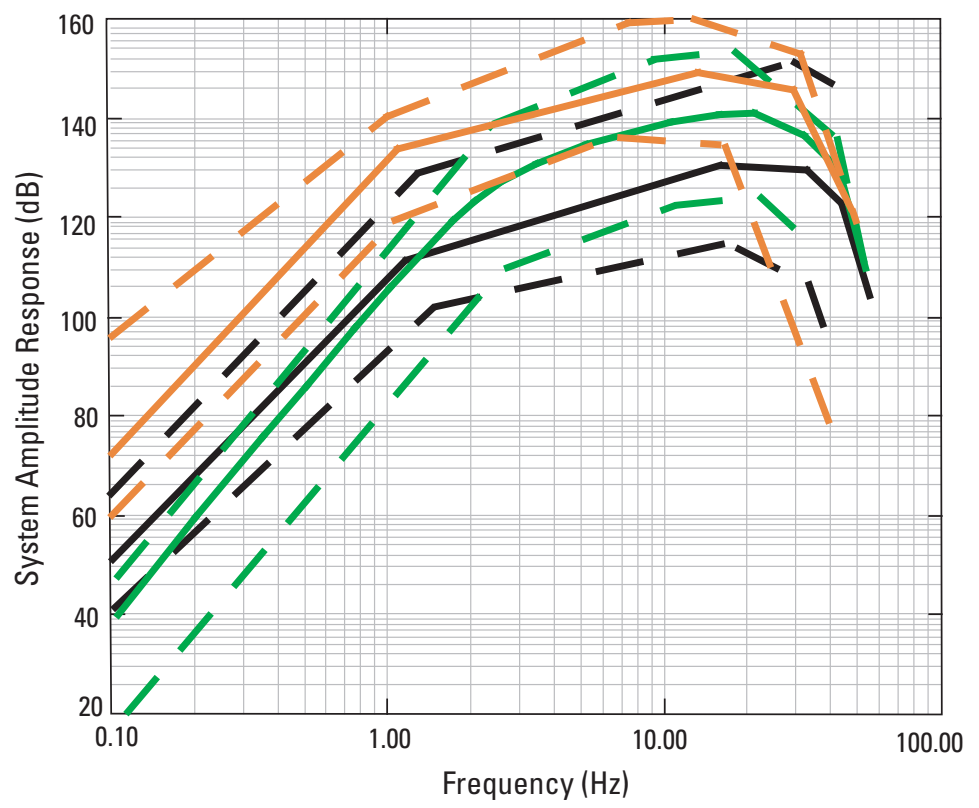

Figure 3. Log-log plot of representative displacement response curves for AVO short-period stations using a L4 (black), S13 (red), or L22 (green) seismometer. Solid lines indicate the typical curves and dashed lines show the range of curves for all AVO stations using the same seismometer.

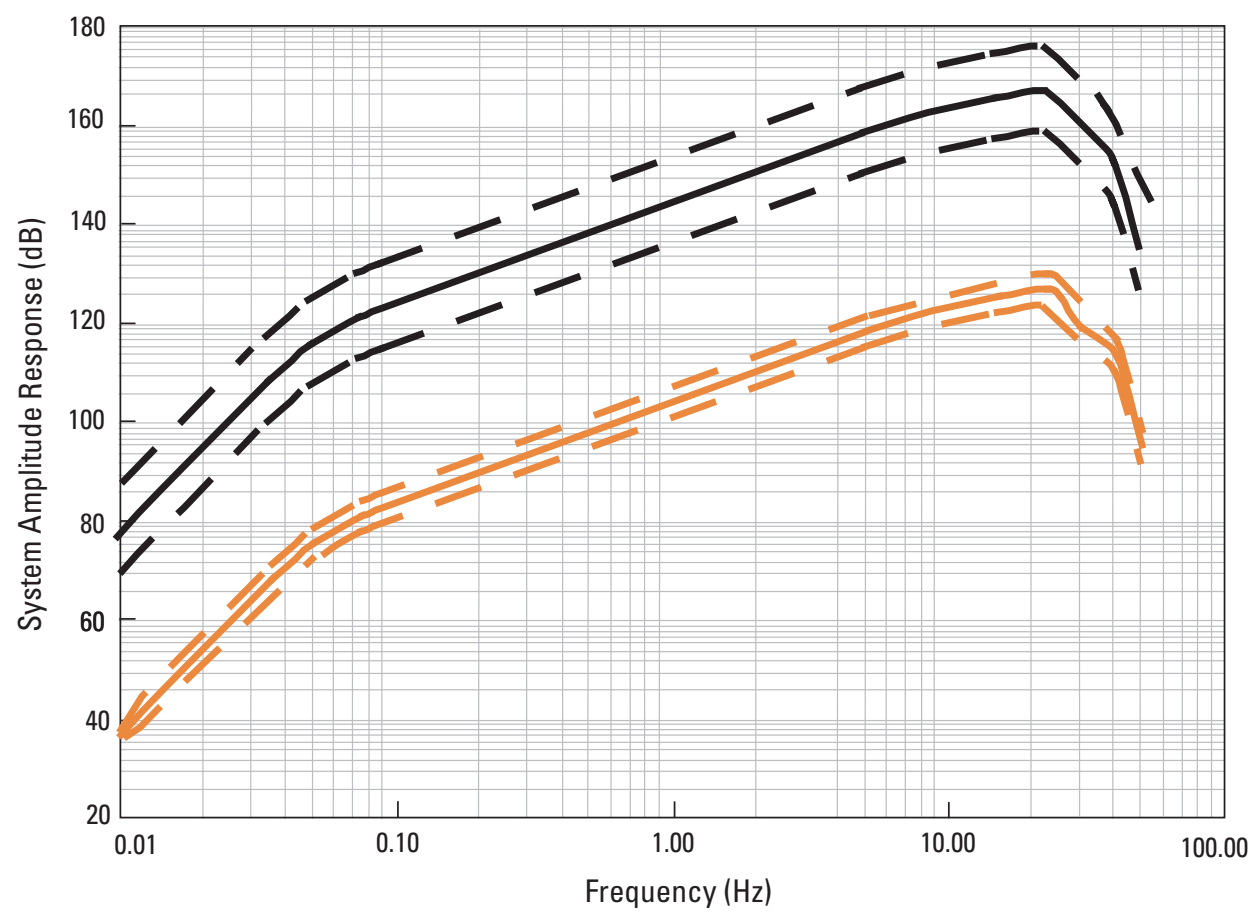

Figure 4. Log-log plot of representative displacement response curves for the AVO broadband stations using a CMG-6TD (black) or CMG-40T (red) seismometer. Solid lines indicate the typical curve and dashed lines show the range of curves for all AVO stations using the same seismometer. 


\section{Data Acquisition and Processing}

Data acquisition for the AVO seismograph network was accomplished with duplicate EARTHWORM systems (Johnson and others, 1995) located in Anchorage and Fairbanks. Data were recorded in both continuous and event detection modes. Event detected data were collected using the EARTHWORM modules Carlstatrig and Carlsubtrig, with the Carlstatrig parameters set as follows: Long-termaverage $($ LTA) time $=8$ seconds, Ratio $=2.3$, and Quiet $=4$. Three station triggers from the Carlstatrig module are required for an event to trigger Carlsubtrig to create an event record. Carlsubtrig was modified such that a two-letter code (table 3) was appended to the filename of each trigger to identify the first subnetwork that triggered. If four or more subnetworks triggered on the same event, all data were saved in a single trigger and tagged as a regional event. All data are saved in Seismic Analysis Code format (Goldstein and others, 1999).

Event triggers were processed daily using the interactive seismic data analysis program XPICK (Robinson, 1990) and the earthquake location program HYPOELLIPSE (Lahr, 1999). Each event trigger was visually inspected and false triggers were deleted. Each subsequent event was identified by a description code (table 4 ) modified after Lahr and others (1994) and stored as a comment in the event location pick file. Earthquakes with a P-wave and S-wave separation of greater than 5 seconds on the closest station were assumed to come from non-volcanic sources and typically were not located. Each hypocenter was checked using a computer algorithm that identified events that did not meet the following minimum parameters: three P-phases, two S-phases, and standard hypocentral errors less than $15 \mathrm{~km}$, as defined by Lahr (1999). If upon reevaluation, the minimum parameters could not be met, the event was removed from the final catalog listing. For the 8,829 earthquakes appearing in the 2009 AVO catalog, the average root-mean-square travel-time error was 0.12 seconds and the average vertical and horizontal hypocentral errors were 1.38 and $2.18 \mathrm{~km}$, respectively. At the time of this report's publication, all hypocentral locations of earthquakes in the AVO seismic catalog have been made available as part of the Advanced National Seismic System (ANSS) catalog. AVO earthquake hypocentral locations are currently being added on a monthly basis to the ANSS catalog after a quality check is performed.

Additional data from seismograph stations operated by the Alaska Earthquake Information Center (AEIC), Global Seismograph Network, and West Coast and Alaska Tsunami Warning Center (WCATWC) were routinely utilized in event detection and location. Station parameters for the WCATWC and AEIC stations used by AVO in 2009 are provided in appendix B.
Table 3. Volcano subnetwork designators.

\begin{tabular}{lcl}
\hline \multicolumn{1}{c}{$\begin{array}{c}\text { Volcano } \\
\text { subnetwork }\end{array}$} & $\begin{array}{c}\text { Network } \\
\text { code }\end{array}$ & Volcanoes monitored \\
\hline Akutan & ak & Akutan Volcano \\
Aniakchak & an & $\begin{array}{l}\text { Aniakchak Crater } \\
\text { Augustine }\end{array}$ \\
Cerberus & au & Augustine Volcano \\
Dutton & Mo & Mount Cerberus \\
Iliamna & dt & Mount Dutton \\
Fourpeaked & fl & Iliamna Volcano \\
Gareloi & ga & Fourpeaked Mountain \\
Great Sitkin & gs & Great Sitkin Volcano \\
Kanaga & ki & Kanaga Volcano \\
Katmai & ka & Mount Griggs, Mount Katmai, \\
& & Mount Mageik and Mount \\
& & Martin, Novarupta, Snowy \\
Korovin & ko & Korovin Volcano \\
Little Sitkin & ls & Little Sitkin Volcano \\
Makushin & ma & Makushin Volcano \\
Okmok & ok & Okmok Caldera \\
Pavlof & pv & Pavlof Volcano \\
Peulik & pl & Ugashik-Peulik and Ukinrek Maars \\
Redoubt & rd & Redoubt Volcano \\
Regional Event & rg & none \\
Shishaldin & sh & Fisher Caldera, Isanotski Peaks, and \\
& & Shishaldin Volcano \\
Spurr & sp & Mount Spurr \\
Tanaga & ta & Tanaga Volcano \\
Veniaminof & vn & Mount Veniaminof \\
Westdahl & we & Fisher Caldera, and Westdahl Peak \\
Wrangell & wa & Mount Wrangell \\
\hline & &
\end{tabular}

Table 4. Alaska Volcano Observatory event description codes.

[Lower case letters refer to triggered events that are located. Upper case letters are used for triggered events that are not typically located]

\begin{tabular}{lc}
\hline \multicolumn{1}{c}{ Event classification } & Classification code \\
\hline Volcano-Tectonic (VT) & $\mathrm{a}$ \\
Low-Frequency (LF) & $\mathrm{b}$ \\
Hybrid & $\mathrm{h}$ \\
Shore-Ice & $\mathrm{i}$ \\
Cause unknown & $\mathrm{x}$ \\
Regional-Volcanic & $\mathrm{R}$ \\
Regional-Tectonic & $\mathrm{E}$ \\
Teleseismic & $\mathrm{T}$ \\
Glacier & $\mathrm{G}$ \\
Calibrations & $\mathrm{C}$ \\
Other non-seismic & $\mathrm{O}$
\end{tabular}




\section{Seismic Velocity Models}

During 2009, AVO used 12 local volcano-specific seismic velocity models and a regional seismic velocity model to locate earthquakes at Alaskan volcanoes. All velocity models were one-dimensional models utilizing horizontal layers to approximate the local seismic velocity structure. Each model, with one exception, assumed a series of constant velocity layers. The single exception was the Akutan velocity model (Power and others, 1996), which had a velocity gradient in a layer overlying a half-space of constant velocity.

One or more vertical cylindrical volumes were used to model the volcanic source zones for all volcanoes where a local velocity model was used. Earthquakes within these cylindrical volumes were located with a local model and earthquakes outside of the cylindrical volumes were located with the regional model. The top of each cylinder was set at $3 \mathrm{~km}$ above sea level and the bottom was set at a depth of 50 $\mathrm{km}$ below sea level. All cylindrical volumes had a radius of 20 $\mathrm{km}$ with the exception of the cylinders centered on Shishaldin and Mount Veniaminof. The cylinder centered on Shishaldin had a radius of $30 \mathrm{~km}$ in order to encompass Fisher Caldera and Isanotski Peaks. The cylinder centered on Veniaminof also had a radius of $30 \mathrm{~km}$ because of the large size of the volcanic edifice.

The Akutan, Augustine (Power, 1988), Iliamna (Roman and others, 2001), Okmok (Masterlark and others, 2010), Tanaga (J.A. Power, written commun., 2005), Veniaminof (Sánchez, 2005) and Westdahl (Dixon and others, 2005) velocity models were used to locate hypocenters that fell within cylindrical volumes described above, centered on each respective volcano. The Cold Bay velocity model (McNutt and Jacob, 1986) was used to locate earthquakes that fell within cylindrical volumes centered on Mount Dutton and Pavlof Volcano. Earthquakes at Fisher, Isanotski, and Shishaldin that fell within the cylindrical regions centered on Shishaldin Volcano also were located using the Cold Bay velocity model. Five overlapping cylinders defined the volume in which the Spurr velocity model (Jolly and others, 1994) was used, four overlapping cylinders defined the volume for the Redoubt velocity model (Lahr and others, 1994), and four overlapping cylinders defined the volume for the Katmai model (Searcy, 2003). The Andreanof velocity model, modified from that in Toth and Kisslinger (1984), was used to locate earthquakes within a volume defined by three cylinders centered on Kanaga Volcano, Mount Moffet, and Great Sitkin Volcano. Specific velocity models for Aniakchak Crater, Mount Cerberus, Mount Gareloi, Korovin Volcano, Little Sitkin Volcano, Makushin Volcano, Mount Peulik, and Mount Wrangell were not available in 2009 and the regional velocity model (Fogleman and others, 1993) was used to locate earthquakes near these volcanoes. The cylindrical model parameters, regional velocity model, and volcanospecific models used to locate earthquakes in this report are summarized in appendix E. Figures showing the volcanic source zones modeled by multiple cylinders are shown in appendix F.

\section{Seismicity}

In 2009, the AVO located 8,829 earthquakes at the 33 volcanic centers with seismograph subnetworks (fig. 5 , appendix A). The 8,829 earthquakes located in 2009 represent a 24 percent increase from the 7,097 earthquakes located in 2008 (Dixon and Stihler, 2009). Of the earthquakes located in 2009,84 percent $(7,438$ earthquakes) were located within $20 \mathrm{~km}$ of a monitored volcanic center. The numbers of located earthquakes associated with volcanic centers during the last 2 years are shown in table 5 . The number of located earthquakes in the AVO catalog by year are shown in table 6 .

Using the 2009 earthquake catalog, the magnitude of completeness (Mc) for each subnetwork was calculated with the exception of seven subnetworks (table 5). Mc is the magnitude threshold above which we are reasonably certain that an event of Mc or greater was detected. The Mc was determined using a maximum likelihood estimate of the inflection point in the frequency magnitude distribution using the seismology analysis software ZMAP (Weimer, 2001). The Aniakchak, Cerberus, Gareloi, Great Sitkin, Pavlof, Veniaminof, and Wrangell subnetworks had insufficient numbers of located earthquakes to calculate a Mc. The Mc ranged from -0.1 to 1.5 for the individual subnetworks.

In 2009, the Volcanic Alert Level was raised at four monitored volcanic centers, Okmok, Redoubt, Shishaldin, and Veniaminof, with only the unrest at Redoubt accompanied by an increase in the number of located earthquakes when compared to previous years. The number of located earthquakes at Westdahl also showed a significant increase in 2009.

Mount Redoubt started the year with the Volcano Alert Level at Advisory. On January 23, 2009, seismic activity consisting of numerous discrete small earthquakes and periods of nearly continuous volcanic tremor increased at the stations closest to Redoubt's summit. The Volcano Alert Level was raised to Watch 2 days later when this seismicity intensified. For the next month, seismicity waxed and waned but remained well above background levels. Following approximately 60 hours of elevated seismicity in the form of discrete earthquakes under the volcano, the eruption of Mount Redoubt began at 06:38 UTC on March 23, 2009, accompanied with a Volcano Alert Level change to Warning. 


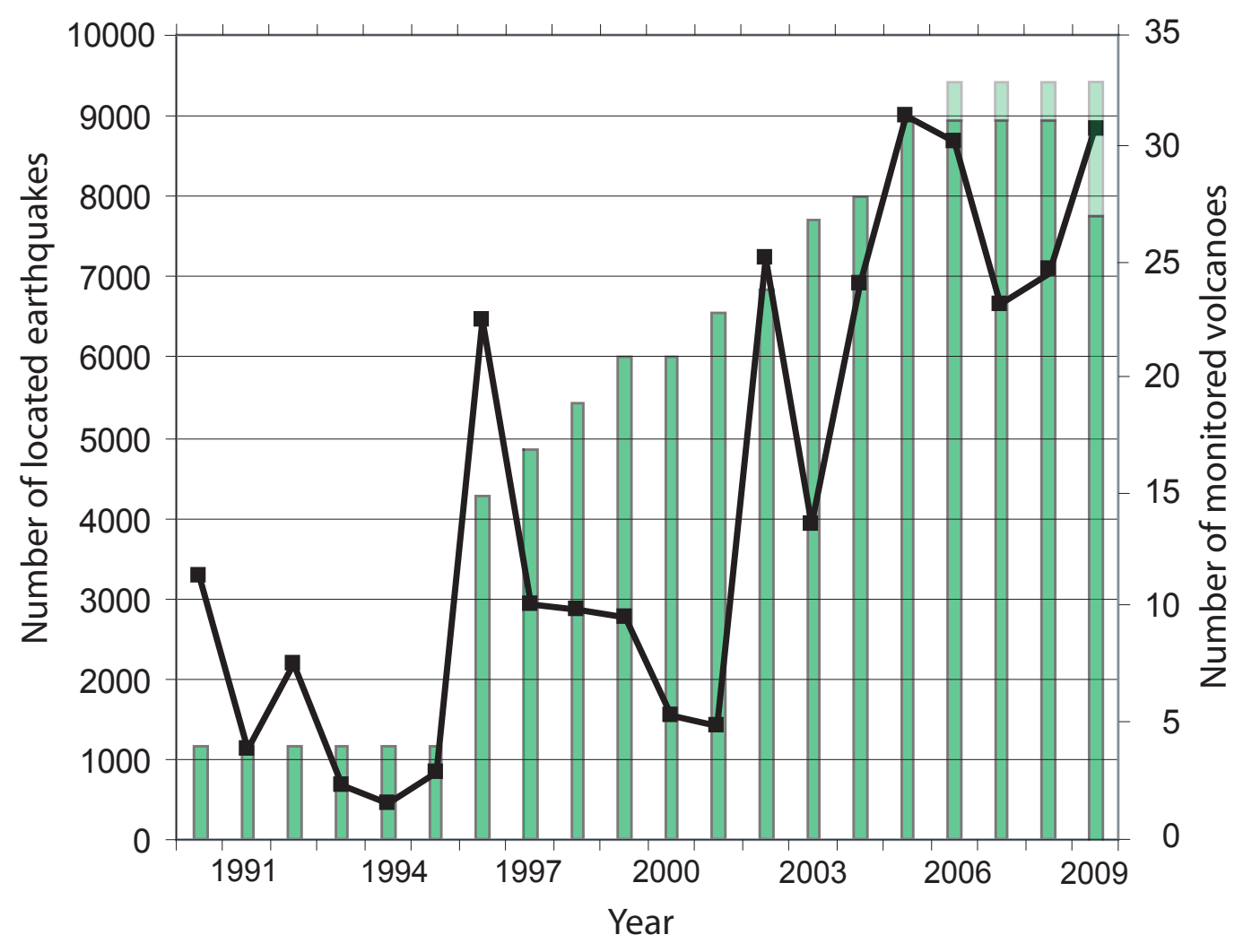

Figure 5. Number of earthquakes located per year in the AVO catalog (black line) and number of monitored volcanoes per year (green bars). The lighter green color indicates the number of volcanoes with seismic networks and not included on the formal list of monitored volcanoes.

A rich variety of seismic signals have been recorded at Redoubt throughout the eruption and in the preceding months of unrest. These seismic events included volcanictectonic earthquakes, volcanic tremor, signals resulting from the volcanic explosions, ground shaking from lahars and pyroclastic flows, and small, repetitive, multiplets associated with the slow extrusion of lava and dome growth.

Seismic activity at Mount Redoubt from mid-April through September was characterized by numerous small volcanic earthquakes and signals from small rock avalanches. On September 29, the Volcano Alert Level was moved to Normal because the volcano appeared to have returned to its normal background condition, posing no immediate threat of eruptive activity. In late December, a series of small repetitive earthquakes occurred in the vicinity of the volcano's summit prompting a raise in the Volcano Alert Level to Watch. The swarm quickly decreased after a few days and the Volcano Alert Level was returned to Normal shortly thereafter.
The number of located earthquakes near Westdahl Peak was well above average in 2009 compared to that in 2008. The increased seismicity was accompanied by an increase in the proportion of located deep long-period earthquakes compared to all located earthquakes. Along with the increase in deep, long-period earthquakes there was an observation from continuous GPS sensors of inflation at Westdahl in late 2009 (Dr. Jeff Freymueller, oral commun., University of Fairbanks, December 12, 2009). A similar pattern was seen in 2002-03 and was followed by an inferred intrusion in 2004 (Dixon and others, 2005).

At three volcanic centers, Okmok, Shishaldin, and Veniaminof, the periods of unrest were not accompanied by an increase in the yearly count of located earthquakes. At Okmok, the Volcanic Alert Level was raised to Advisory between March 2 and March 20 in response to short bursts of volcanic tremor occurring at an average rate of one per hour. 
Table 5. Number of earthquakes located for each seismograph subnetwork in 2009 within $20 \mathrm{~km}$ of the volcanic centers in each subnetwork.

[The totals for 2009 are broken into three event types: volcanic-tectonic (VT), low-frequency (LF) and other (all other possible event types shown in table 4). Magnitude of completeness (Mc) for AVO seismograph subnetworks used the 2009 data]

\begin{tabular}{|c|c|c|c|c|c|c|}
\hline Volcano subnetwork & $\begin{array}{l}\text { Earthquakes } \\
\text { located in } 2008\end{array}$ & $\begin{array}{l}\text { Earthquakes } \\
\text { located in } 2009\end{array}$ & $\begin{array}{c}2009 \\
\text { VT }\end{array}$ & $\begin{array}{c}2009 \\
\text { LF }\end{array}$ & $\begin{array}{l}2009 \\
\text { Other }\end{array}$ & $\begin{array}{c}2009 \\
\text { Mc }\end{array}$ \\
\hline Akutan & 105 & 45 & 41 & 4 & 0 & 0.8 \\
\hline Aniakchak & 1 & 22 & 4 & 18 & 0 & $\left({ }^{1}\right)$ \\
\hline Augustine & 116 & 34 & 29 & 0 & 5 & -0.1 \\
\hline Cerberus & 21 & 11 & 11 & 0 & 0 & $\left({ }^{1}\right)$ \\
\hline Dutton & 19 & 32 & 28 & 0 & 4 & 0.8 \\
\hline Fourpeaked & 11 & 16 & 16 & 0 & 0 & 1.0 \\
\hline Gareloi & 87 & 30 & 28 & 0 & 2 & $(1)$ \\
\hline Great Sitkin & 33 & 36 & 35 & 0 & 1 & $(1)$ \\
\hline Iliamna & 102 & 173 & 159 & 13 & 1 & 0.3 \\
\hline Kanaga & 478 & 28 & 26 & 0 & 2 & 1.5 \\
\hline Katmai Cluster & 1,987 & 1,338 & 1,327 & 11 & 0 & 0.4 \\
\hline Korovin & 47 & 78 & 72 & 6 & 0 & 0.3 \\
\hline Little Sitkin & 235 & 57 & 57 & 0 & 0 & 0.7 \\
\hline Makushin & 117 & 141 & 141 & 0 & 0 & 0.7 \\
\hline Okmok & 635 & 151 & 148 & 3 & 0 & 1.2 \\
\hline Pavlof & 9 & 7 & 7 & 0 & 0 & $\left({ }^{1}\right)$ \\
\hline Peulik & 21 & 10 & 10 & 0 & 0 & 0.9 \\
\hline Redoubt & 107 & 4,246 & 3,860 & 386 & 0 & 0.4 \\
\hline Shishaldin & 290 & 257 & 227 & 30 & 0 & 0.6 \\
\hline Spurr & 599 & 411 & 381 & 28 & 2 & 0.1 \\
\hline Tanaga & 401 & 250 & 241 & 0 & 9 & 1.2 \\
\hline Veniaminof & 17 & 4 & 3 & 1 & 0 & $\left({ }^{1}\right)$ \\
\hline Westdahl & 11 & 56 & 37 & 19 & 0 & 1.0 \\
\hline Wrangell & 83 & 5 & 5 & 0 & 0 & $\left({ }^{1}\right)$ \\
\hline Totals & 5,318 & 7,438 & 6,893 & 519 & 26 & $\left({ }^{1}\right)$ \\
\hline
\end{tabular}

${ }^{1}$ Insufficient number of located earthquakes and therefore an Mc could not be computed.

This increase above typical background activity quickly died away and by March 20 was back to background levels. The Volcanic Alert Level for Shishaldin was raised to Advisory for two time periods. On January 6, AVO seismic networks recorded a small but significant number of earthquakes below the volcano that was accompanied by a thermal anomaly observed in satellite imagery. This anomalous activity decreased to background by February 11 when the Volcanic Alert Level was lowered to Normal. There was no appreciable change in seismicity detected in the unrest at Shishaldin when the Volcanic Alert Level was raised to Advisory between July 10 and October 19 based on changes in observed satellite imagery. The unrest at Veniaminof began on May 7 when increased low level earthquake activity was detected and continued for 2 weeks. On May 26, when the seismic activity had diminished, the Volcano Alert Level was returned to Normal.
Six subnetworks (Akutan, Augustine, Cerberus, Gareloi, Pavlof, and Peulik), saw a decrease in the number of located earthquakes in 2009 compared to the number of earthquakes located in 2008. The remaining five subnetworks have an apparent decrease in located seismicity in 2009 compared to 2008 that is explained by station outages. The number of located earthquakes at the Aktuan, Aniakchak, Dutton, Fourpeaked, Great Sitkin, Iliamna, Little Sitkin, Kanaga Island, Makushin, Okmok, Shishaldin, Spurr, Tanaga, Veniaminof, and Wrangell subnetworks were similar to that in preceding years. 
Table 6. Number of earthquakes located per year in the Alaska Volcano Observatory earthquake catalog.

\begin{tabular}{cccc}
\hline Year & $\begin{array}{c}\text { Number of } \\
\text { earthquakes } \\
\text { located } \\
\text { per year }\end{array}$ & $\begin{array}{c}\text { Number of } \\
\text { earthquakes } \\
\text { located per } \\
\text { year within } \\
\text { 20 km of } \\
\text { a volcano }\end{array}$ & $\begin{array}{c}\text { Volcanoes with } \\
\text { an AVO } \\
\text { seismograph } \\
\text { network }\end{array}$ \\
\hline 1989 & & 892 & \\
1990 & 3,285 & 3,148 & 4 \\
1991 & 1,119 & 1,064 & 4 \\
1992 & 2,184 & 2,104 & 4 \\
1993 & 697 & 592 & 4 \\
1994 & 441 & 407 & 4 \\
1995 & 850 & 760 & 4 \\
1996 & 6,466 & 4,259 & 14 \\
1997 & 2,930 & 1,783 & 17 \\
1998 & 2,873 & 1,886 & 20 \\
1999 & 2,769 & 2,343 & 22 \\
2000 & 1,551 & 1,225 & 22 \\
2001 & 1,427 & 1,122 & 23 \\
2002 & 7,242 & 6,578 & 24 \\
2003 & 3,911 & 3,264 & 27 \\
2004 & 6,928 & 6,105 & 30 \\
2005 & 9,012 & 8,146 & 32 \\
2006 & 8,666 & 7,782 & 33 \\
2007 & 6,664 & 5,660 & 33 \\
2008 & 7,097 & 5,318 & 33 \\
2009 & 8,829 & 7,438 & \\
\hline
\end{tabular}

\section{Summary}

Between January 1 and December 31, 2009, AVO located 8,829 earthquakes, of which 7,438 occurred at or near volcanoes in Alaska. Monitoring highlights in 2009 include the eruption of Redoubt Volcano, as well as increased unrest at Mount Veniaminof, Shishaldin Volcano, and Okmok Caldera.

Available for download with this report is a compressed Unix tar-file containing a summary listing of earthquake hypocenters and all necessary HYPOELLIPSE input files to recalculate the hypocenters including station locations and calibrations, seismic velocity models, and phase information. A dataless SEED volume for the AVO Seismograph network is included in the data supplement. The reader should refer to Lahr (1999) for information on file formats and instructions for configuring and running the location program
HYPOELLIPSE. Continuous waveform data for selected AVO seismograph stations are archived and available through the Incorporated Research Institutions for Seismology (IRIS) (www.iris.edu). Archives of waveform data are maintained on DVD-ROM at AVO offices in Fairbanks and Anchorage.

AVO earthquake catalogs for 1989-2008 are listed in appendix G. Selected papers published in 2009 that utilized AVO seismic data are listed in appendix H.

\section{Acknowledgments}

The contents of this report reflect a great deal of hard work by a large number of people including AVO, Alaska Earthquake Information Center (AEIC), and USGS personnel and various students, interns, and volunteers. We thank the AEIC and the West Coast and Alaska Tsunami Warning Center for the use of their data. We thank Wes Thelen of the U.S Geological Survey and Matt Gardine of the University of Alaska Fairbanks for formal reviews of the text and figures.

\section{References Cited}

Dixon, J.P., Power, J.A., and Stihler, S.D., 2005, Seismic observations of Westdahl Volcano and Western Unimak Island, Alaska: 1999-2005 [abs.]: American Geophysical Union Transactions, v. 86, Fall Meeting Supplement, Abstract S11b-0169.

Dixon, J.P., and Stihler, S.D., 2009, Catalog of earthquake hypocenters at Alaskan Volcanoes: January 1 through December 31, 2008: U.S. Geological Survey Data Series 467, 88 p. (Also available at http://pubs.usgs.gov/ds/467/.)

Fogleman, K.A., Lahr, J.C., Stephens, C.D., and Page, R.A., 1993, Earthquake locations determined by the southern Alaska seismograph network for October 1971 through May 1989: U.S. Geological Survey Open-File Report 93-309, $54 \mathrm{p}$.

Goldstein, P., Dodge, D., and Firpo, M., 1999, SAC2000: Signal processing and analysis tools for seismologists and engineers, in Lee, W.H.K., Kanamori, H., Jennings, P.P., Kisslinger, C., eds., International Handbook of Engineers and Engineering Seismology, v. 81B, San Diego, CA, Academic Press, p. 1613-1614. 
Johnson, C.E., Bittenbinder, A., Bogaert, D., Dietz, L., and Kohler, W., 1995, EARTHWORM: A flexible approach to seismograph network processing: Incorporated Research Institutions for Seismology Newsletter, v. 14, no. 2, p. 1-4.

Jolly, A.D., Page, R.A., and Power, J.A., 1994, Seismicity and stress in the vicinity of Mt. Spurr volcano, south-central Alaska: Journal of Geophysical Research, v. 99, p. 1530515318.

Lahr, J.C., 1999, HYPOELLIPSE: A computer program for determining local earthquake hypocentral parameters, magnitude, and first motion pattern: U.S. Geological Survey Open-File Report 99-23, 116 p.

Lahr, J.C., Chouet, B.A., Stephens, C.D., Power, J.A., and Page, R.A., 1994, Earthquake classification, location, and error analysis in a volcanic environment: Implications for the magmatic system of the 1989-90 eruptions at Redoubt Volcano, Alaska: Journal of Volcanology and Geothermal Research, v. 62, p. 137-152.

Masterlark, T., Haney, M., Dickinson, H., Fournier, T., and Searcy, C., 2010, Rheological and structrual controls on the deformation of Okmok Volcano, Alaska: FEM's InSAR, and ambient noise tomography: Journal of Geophysical Research ,v. 115, B02409, doi:10.1029/2009JB006324, accessed August 13, 2010, at http://www.agu.org/journals/ ABS/2010/2009JB006324.shtml.

McChesney, P.J., 1999, McVCO Handbook 1999: U.S. Geological Survey Open-File Report 99-361, 48 p. (Also available at http://geopubs.wr.usgs.gov/open-file/of99$\underline{361 / .)}$

McNutt, S.R., and Jacob, K.H, 1986, Determination of largescale velocity structure of the crust and upper mantle in the vicinity of Pavlof Volcano, Alaska: Journal of Geophysical Research, v. 91, p. 5013-5022.
Neal, C.A., Larsen, J.F., and Schaefer, Janet, 2009, The July-August 2008 hydrovolcanic eruption of Okmok Volcano, Umnak Island, Alaska: Alaska Geological Society Newsletter, v. 39, no. 5.

Power, J.A., 1988, Seismicity associated with the 1986 eruption of Augustine Volcano, Alaska: Fairbanks, University of Alaska Fairbanks, Masters Thesis, 149 p.

Power, J.A., Paskievitch, J.F., Richter, D.H., McGimsey, R.G., Stelling, P., Jolly, A.D., and Fletcher, H.J., 1996, 1996 seismicity and ground deformation at Akutan Volcano: American Geophysical Union Transactions, v. 77, p. F514.

Robinson, M., 1990, XPICK users manual, version 2.7: University of Alaska Fairbanks, Seismology Lab, Geophysical Institute, 93 p.

Roman, D.C., Power, J.A., Moran, S.C., Cashman, K.V., and Stihler, S.D., 2001, Unrest at Iliamna Volcano, Alaska in 1996, Evidence for a magmatic intrusion [abs.]: American Geophysical Union Transactions, v. 82, p. F1329.

Sánchez, J.J., 2005, Volcano seismology from around the World: Case studies from Mount Pinatubo (Philippines), Galeras (Columbia), Mount Wrangell and Mount Veniaminof (Alaska): Fairbanks, University of Alaska Fairbanks, Ph.D. dissertation, 208 p.

Searcy, C.K., 2003, Station corrections for the Katmai Region seismograph network: U.S. Geological Survey Open-File Report 03-403, 16 p.

Toth, T., and Kisslinger, C., 1984, Revised focal depths and velocity model for local earthquakes in the Adak seismic zone: Bulletin of the Seismological Society of America, v. 74 , p. 1349-1360.

Wiemer, S., 2001, A software package to analyze seismicity: ZMAP: Seismological Research Letters, v. 72, p. 373-382. 
This page left intentionally blank 


\section{Appendix A. Maps of Monitored Volcanoes with Earthquake Hypocenters Calculated in 2009.}
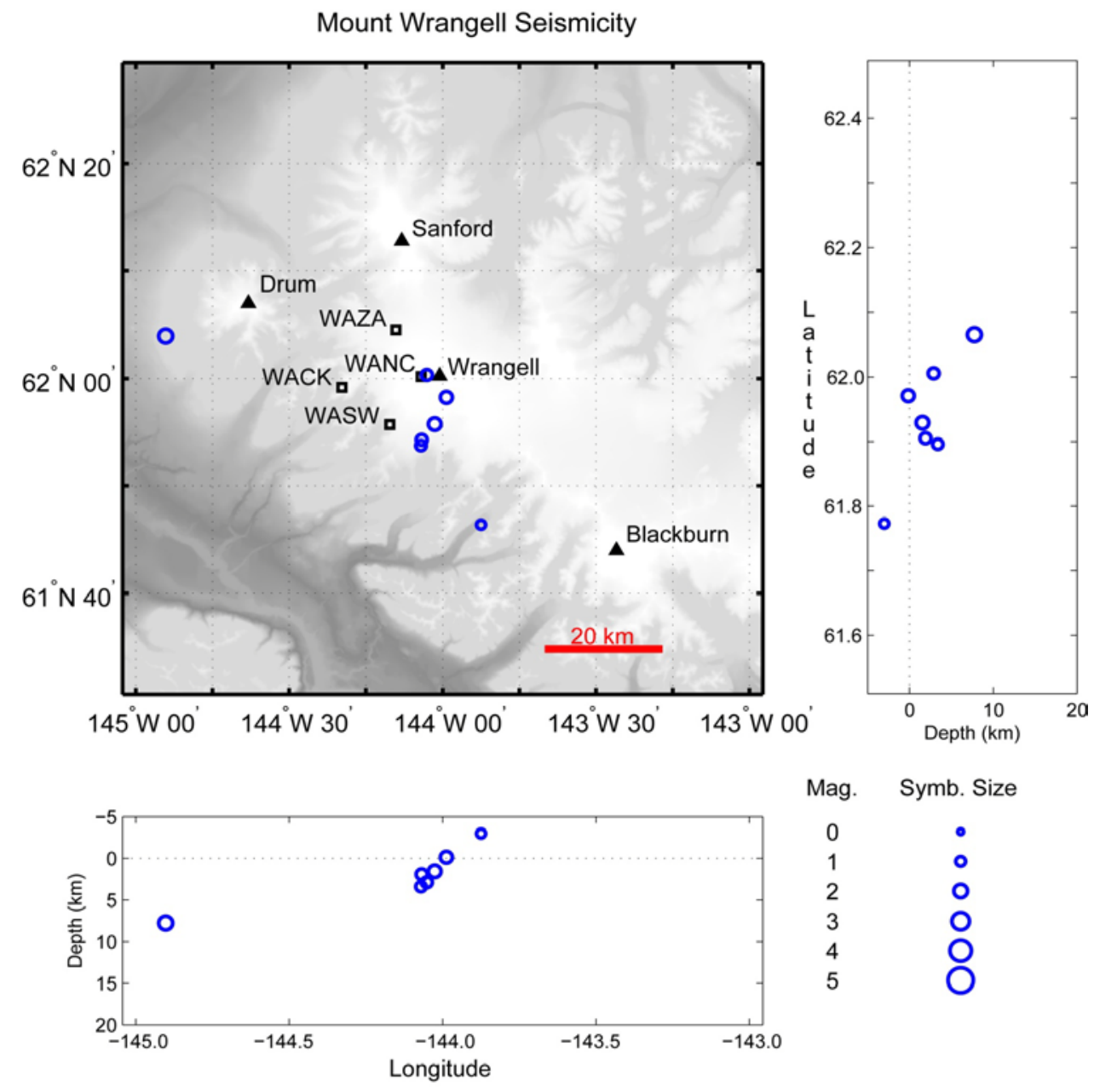

Mag. Symb. Size
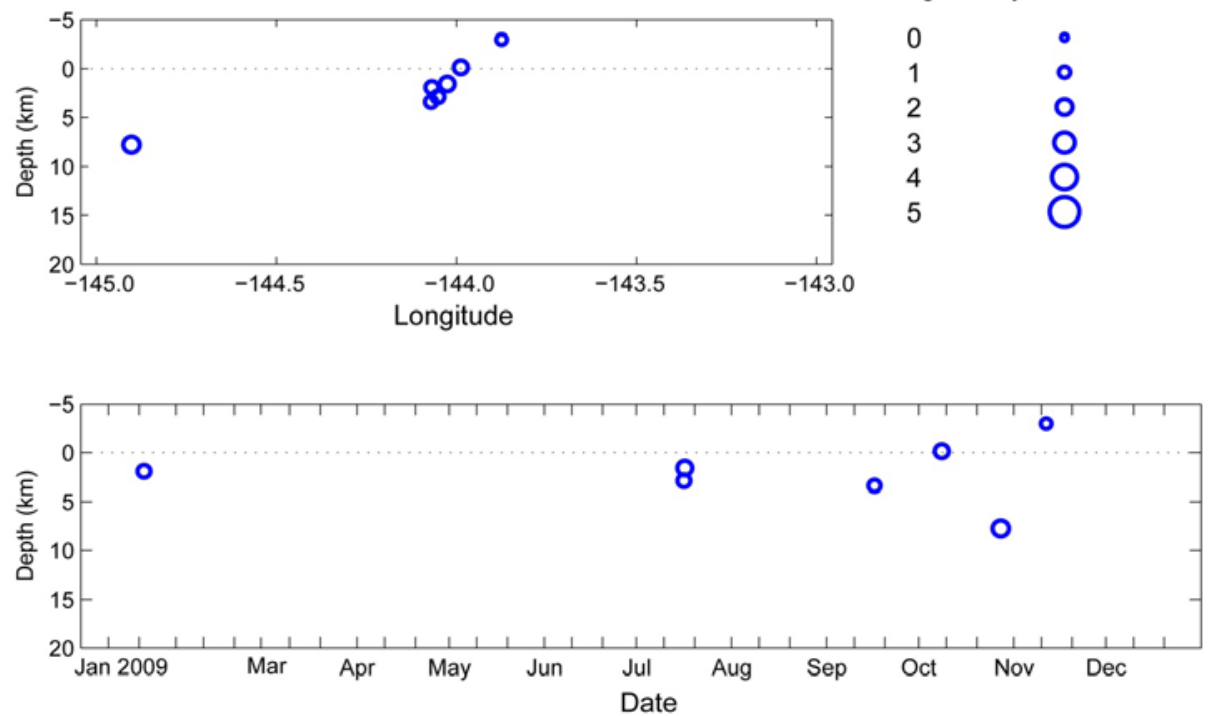

Figure A1. Summary plots of earthquakes located near Mount Wrangell in 2009. Open circles indicate hypocenters shallower than $20 \mathrm{~km}$ with symbols scaled with magnitude. Permanent seismograph stations are shown by open squares and labeled by station code. Solid triangles are used to show volcanic centers. Vertical exaggeration is $x \times 1.5$. See appendix $B$ for station information. 

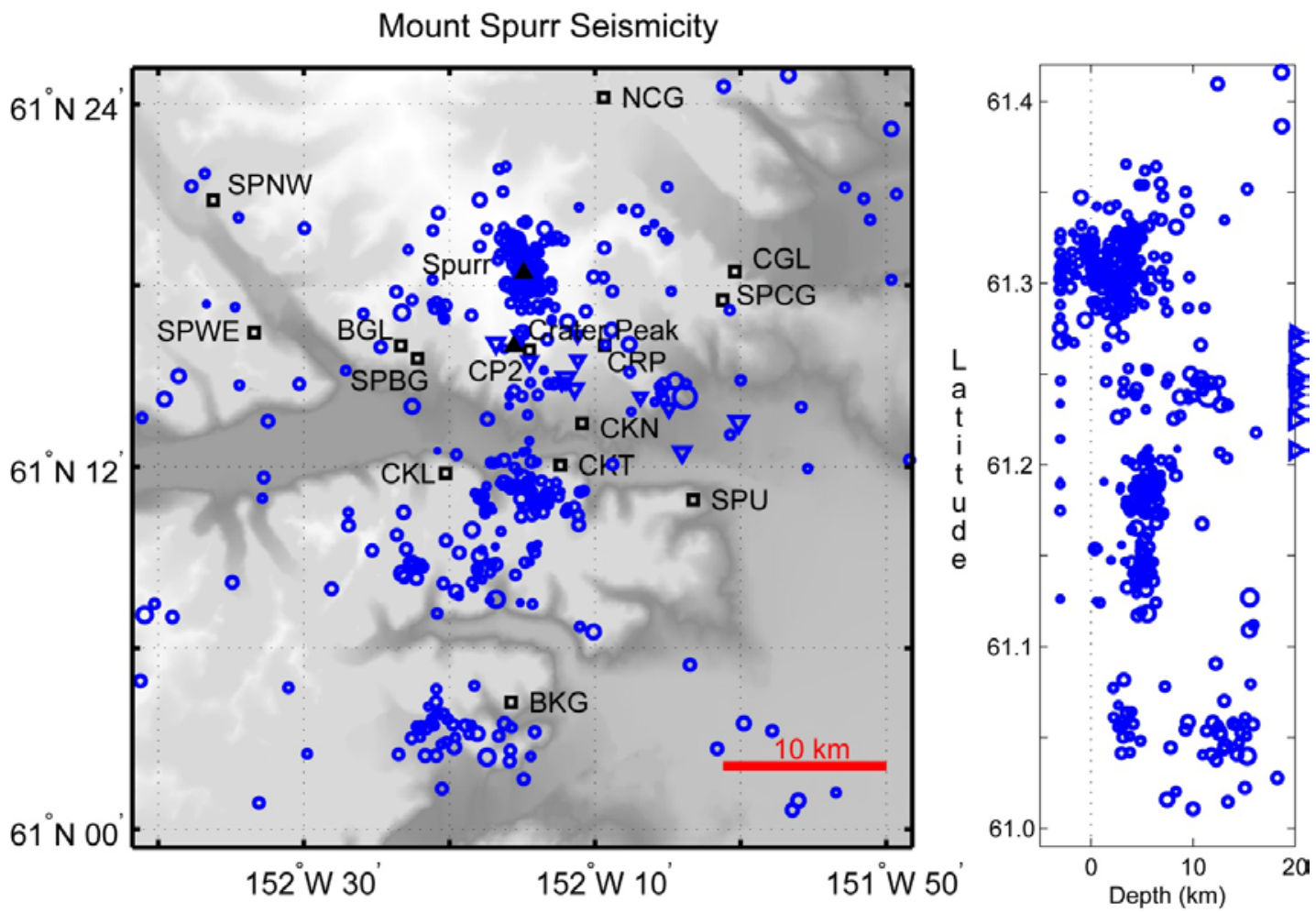

Mag. Symb. Size
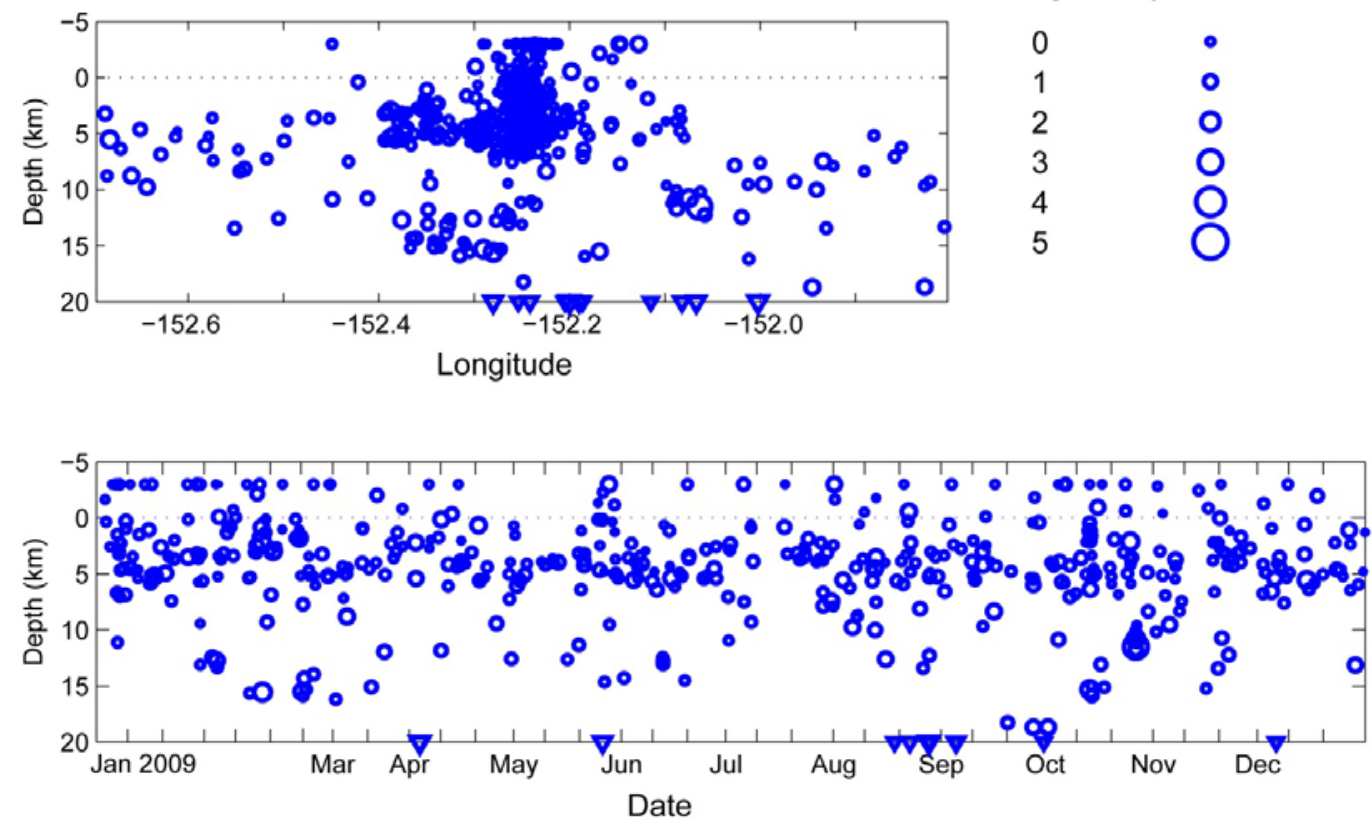

Figure A2. Summary plots of earthquakes located near Mount Spurr in 2009. Open circles indicate hypocenters shallower than $20 \mathrm{~km}$ and open triangles indicate hypocenters with depths of $20 \mathrm{~km}$ and deeper. Hypocenter symbols are scaled with magnitude. Permanent seismograph stations are shown by open squares and labeled by station code. Solid triangles are used to show volcanic centers. Vertical exaggeration is $\mathrm{x} 0.6$. See appendix B for station information. 

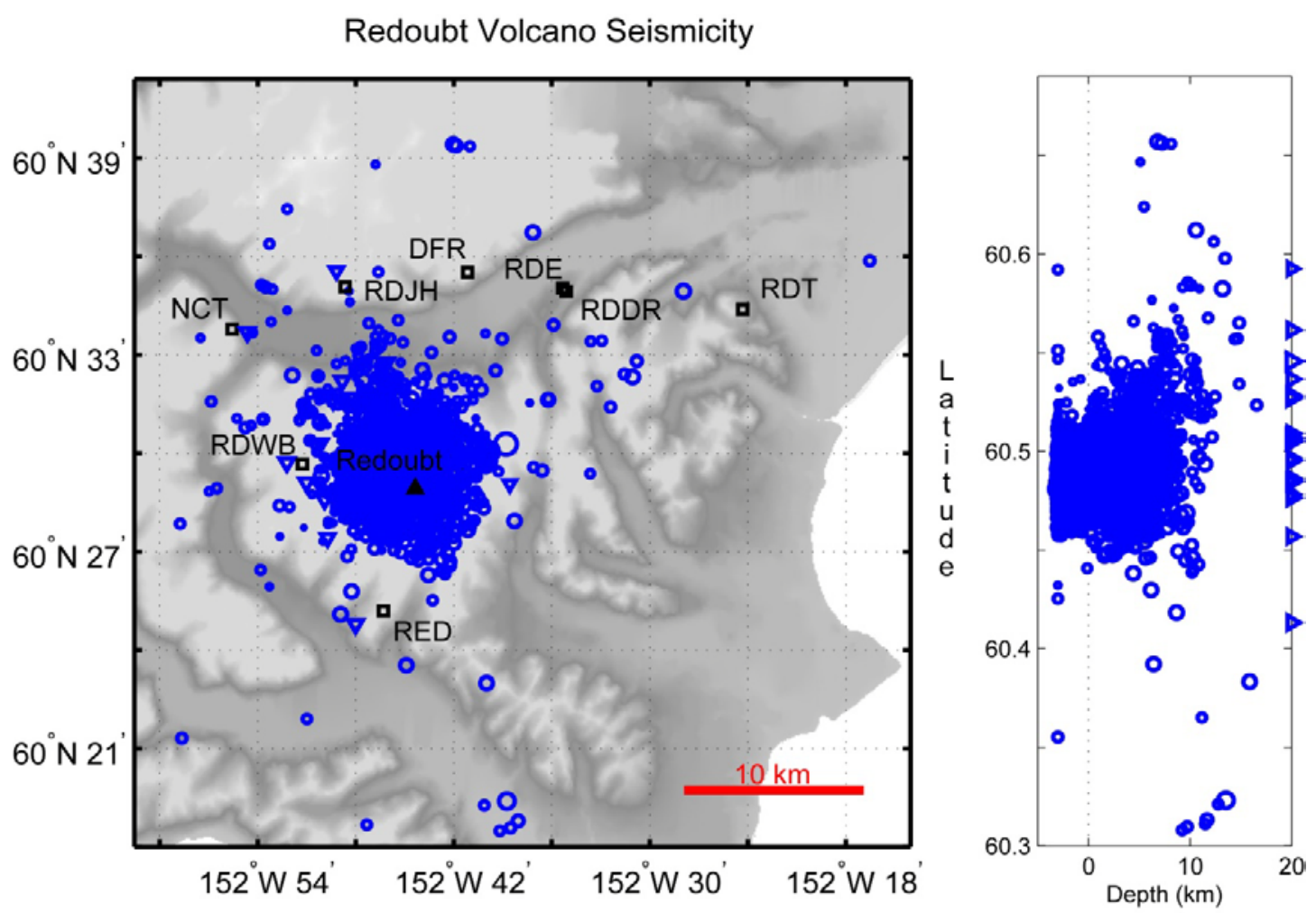

Mag. Symb. Size

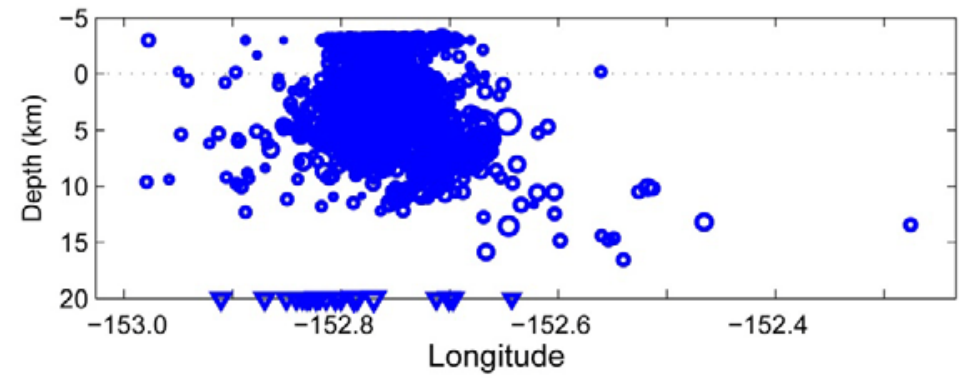

$\begin{array}{ll}0 & 0 \\ 1 & \circ \\ 2 & 0 \\ 3 & 0 \\ 4 & \bigcirc \\ 5 & \bigcirc\end{array}$

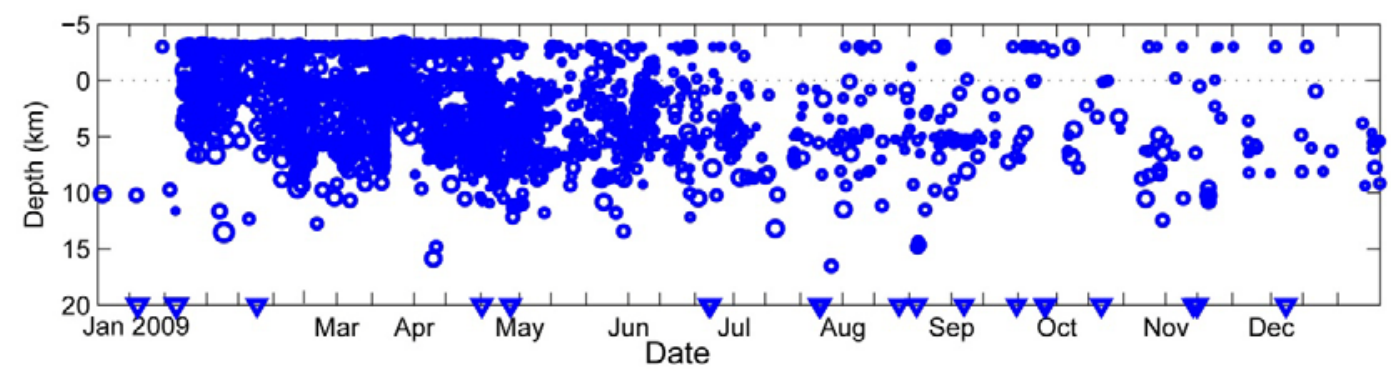

Figure A3. Summary plots of earthquakes located near Redoubt Volcano in 2009. Open circles indicate hypocenters shallower than $20 \mathrm{~km}$ and open triangles indicate hypocenters with depths of $20 \mathrm{~km}$ and deeper. Hypocenter symbols are scaled with magnitude. Permanent seismograph stations are shown by open squares and labeled by station code. Solid triangles are used to show volcanic centers. Vertical exaggeration is $\mathrm{x} 0.6$. See appendix B for station information. 

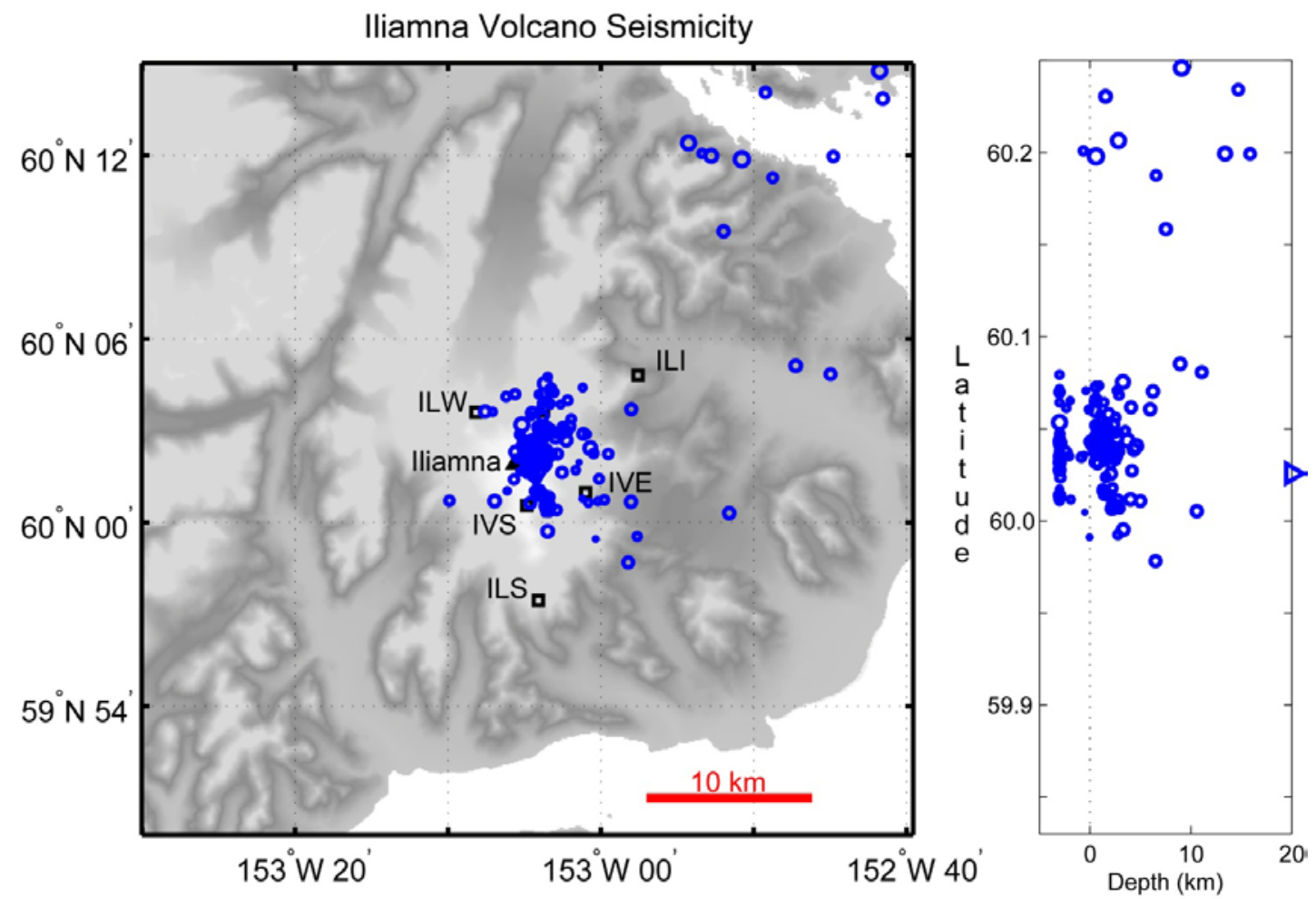

Mag. Symb. Size

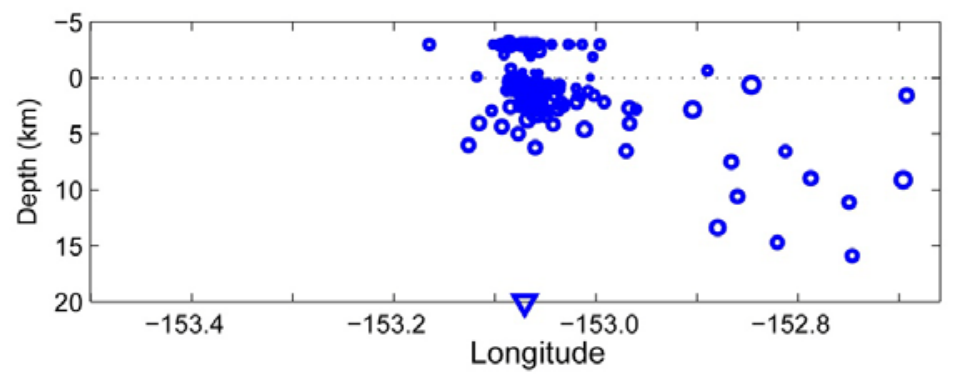

$\circ$
$\circ$
0
0
0
0

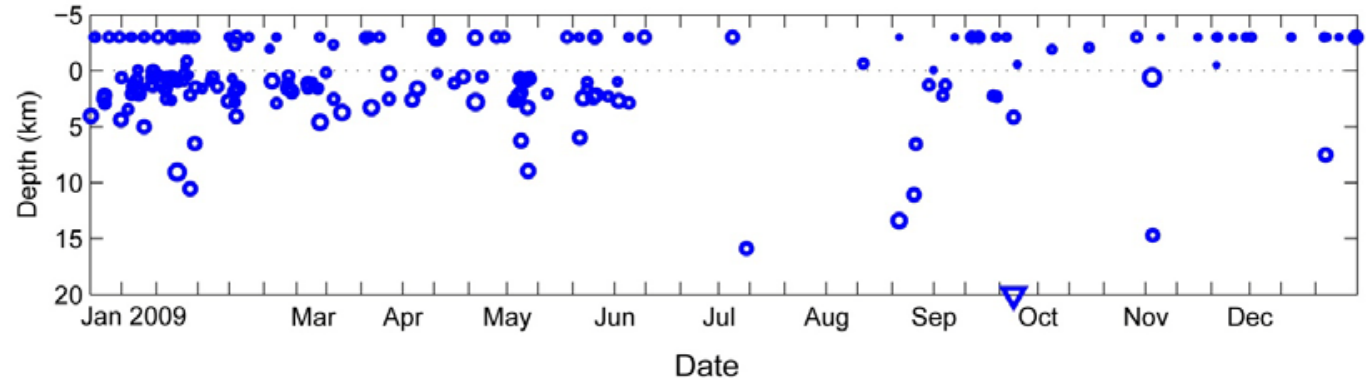

Figure A4. Summary plots of earthquakes located near lliamna Volcano in 2009. Open circles indicate hypocenters shallower than $20 \mathrm{~km}$ and open triangles indicate hypocenters with depths of $20 \mathrm{~km}$ and deeper. Hypocenter symbols are scaled with magnitude. Permanent seismograph stations are shown by open squares and labeled by station code. Solid triangles are used to show volcanic centers. Vertical exaggeration is $\mathrm{x} 0.6$. See appendix $\mathrm{B}$ for station information. 

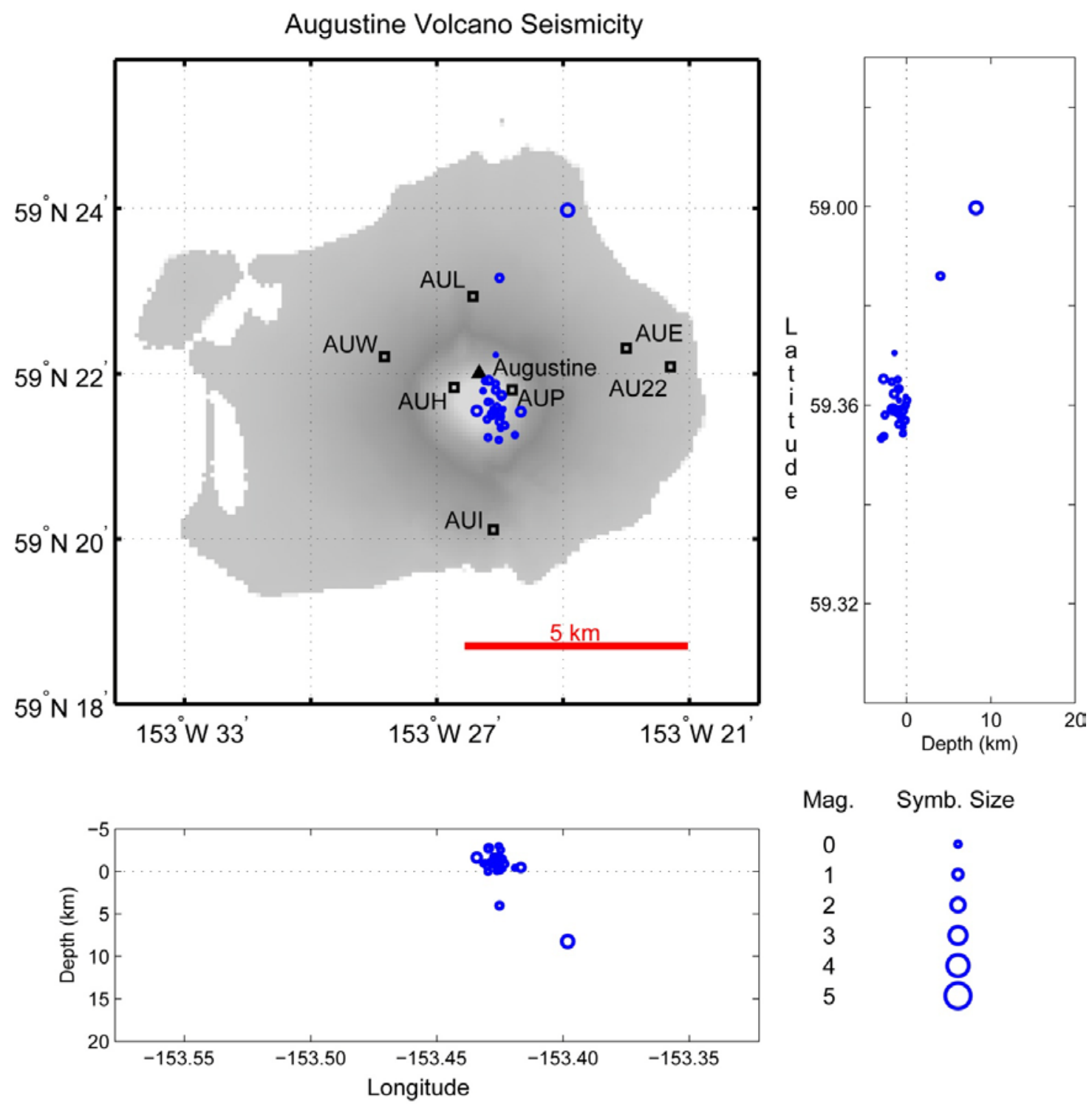

Mag. Symb. Size
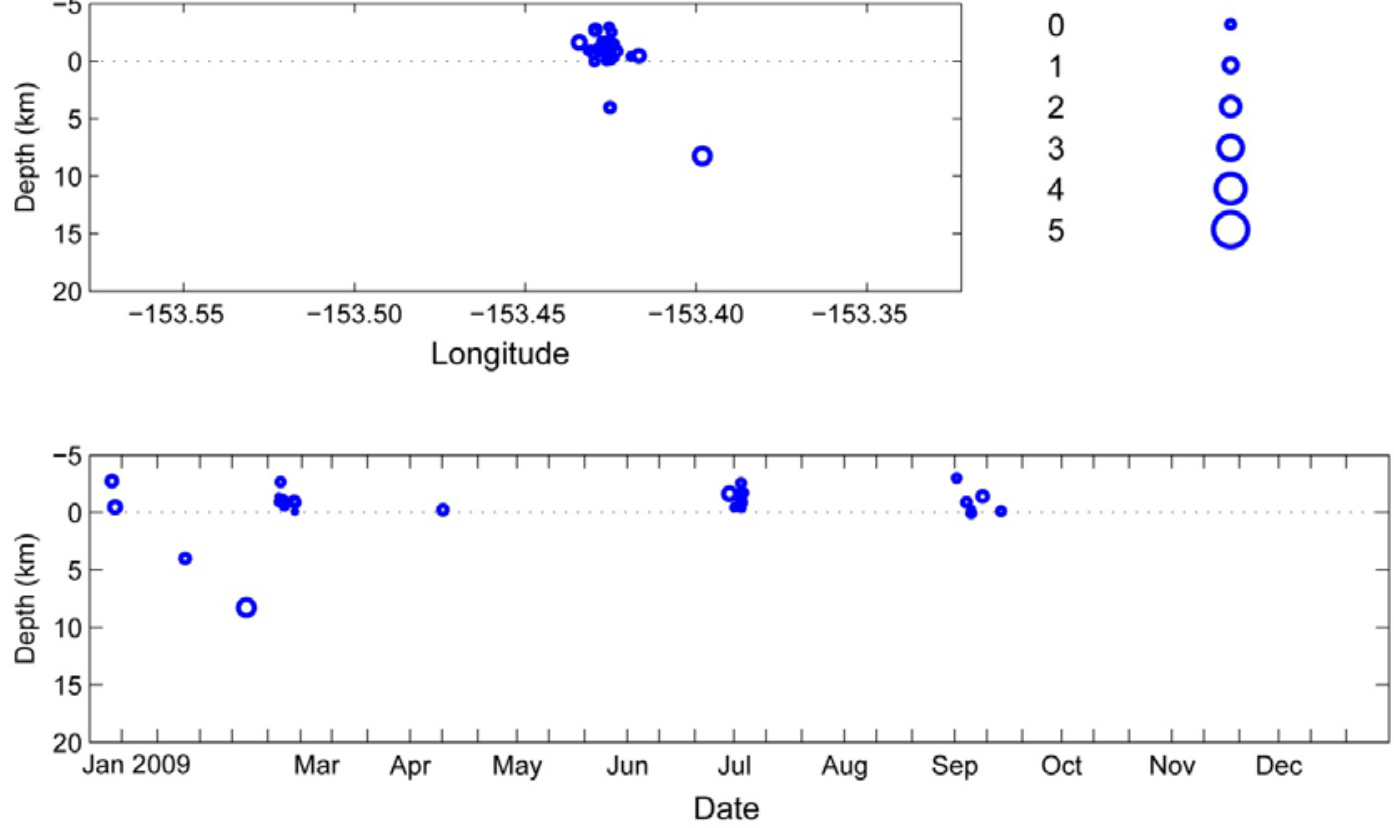

Figure A5. Summary plots of earthquakes located near Augustine Volcano in 2009. Open circles indic ate hypocenters shallower than $20 \mathrm{~km}$ with symbols scaled with magnitude. Permanent seismograph stations are shown by open squares and labeled by station code. Solid triangles are used to show volcanic centers. Vertical exaggeration is $x 0.2$. See appendix $B$ for station information. 

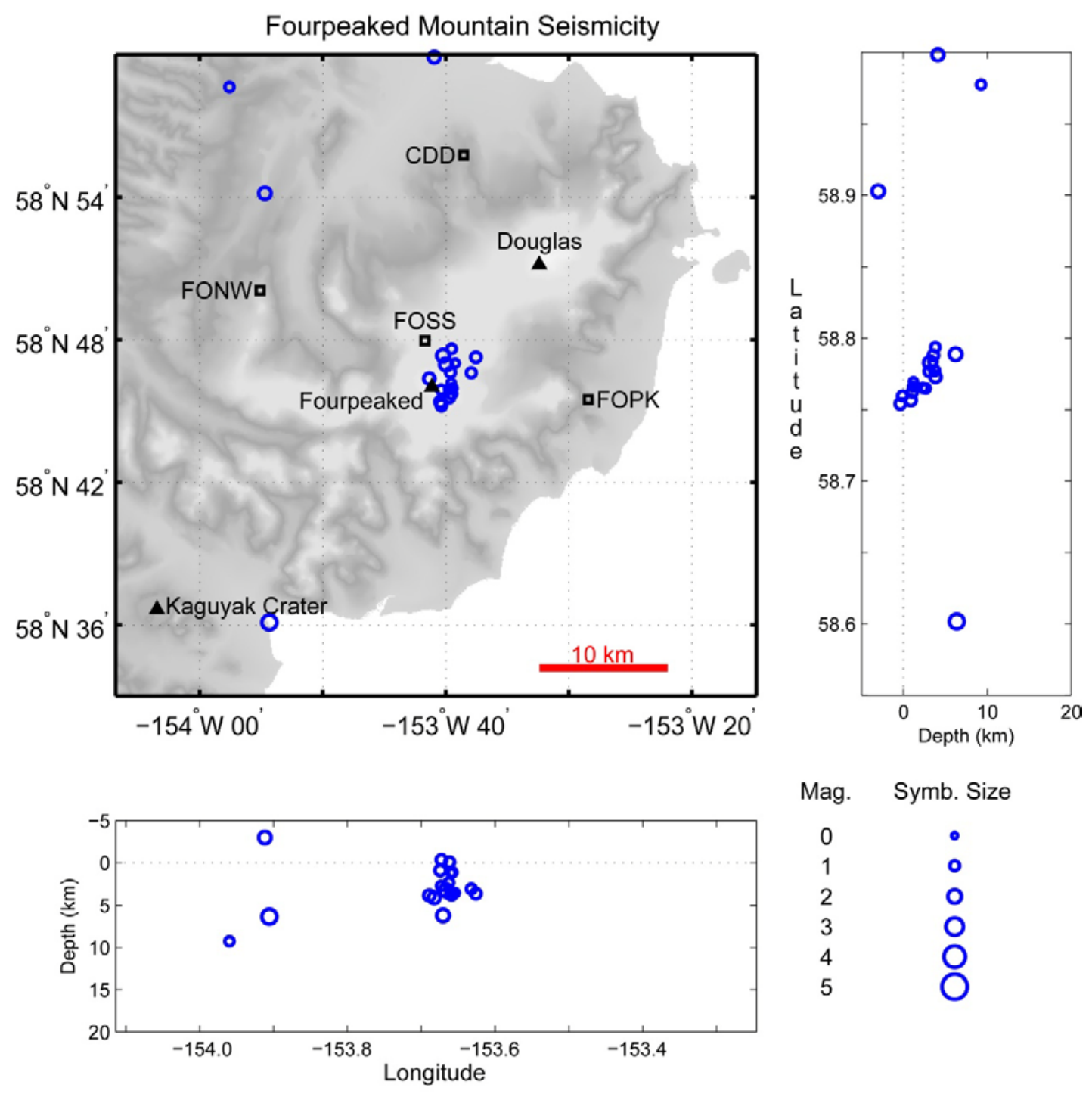

Mag. Symb. Size

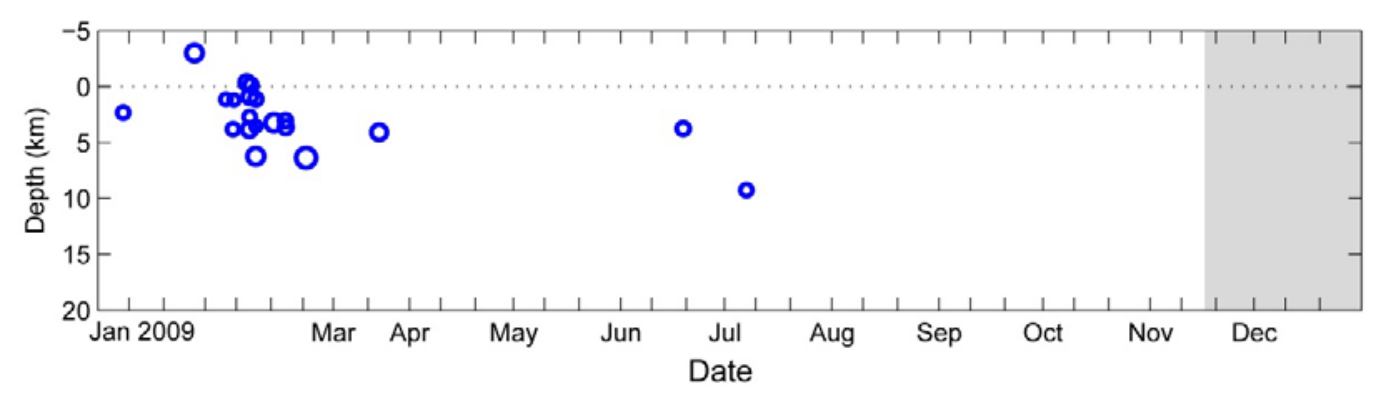

Figure A6. Summary plots of earthquakes located near Fourpeaked Mountain in 2009. Open circles show hypocenter locations shallower than $20 \mathrm{~km}$. Hypocenter symbols are scaled with magnitude. Permanent seismograph stations are shown by open squares and labeled by station code. The gray shaded area in time depth plot shows the time frame the subnetwork was not on the monitored volcano list. Solid triangles are used to show volcanic centers. Vertical exaggeration is $x 0.7$. See appendix B for station information. 
Katmai Volcanic Cluster Seismicity
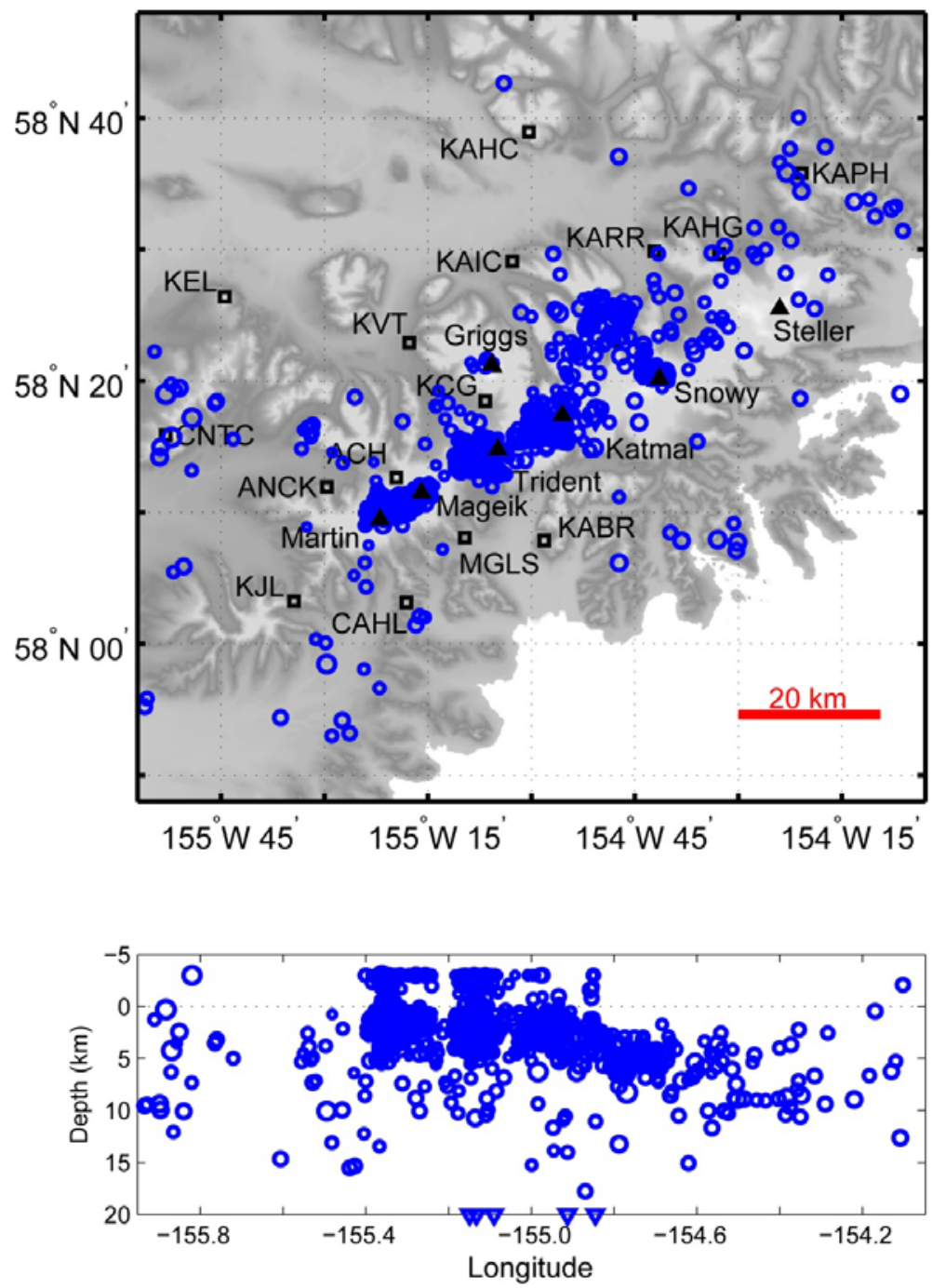

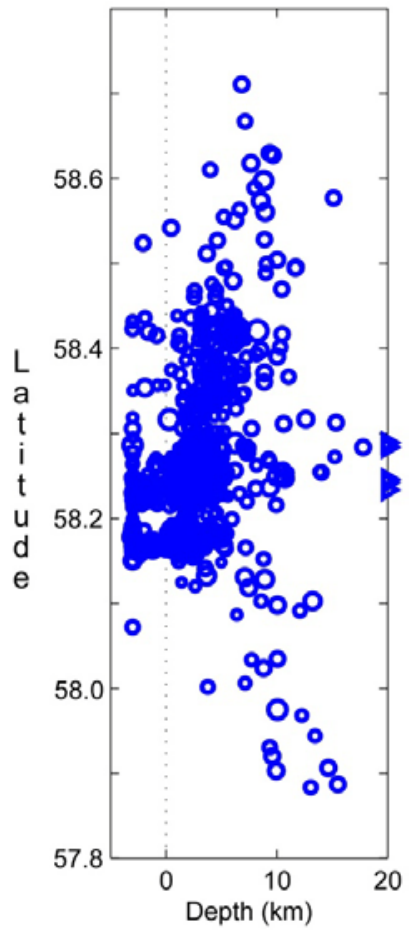

Mag. Symb. Size

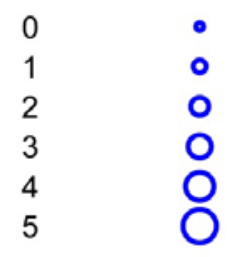

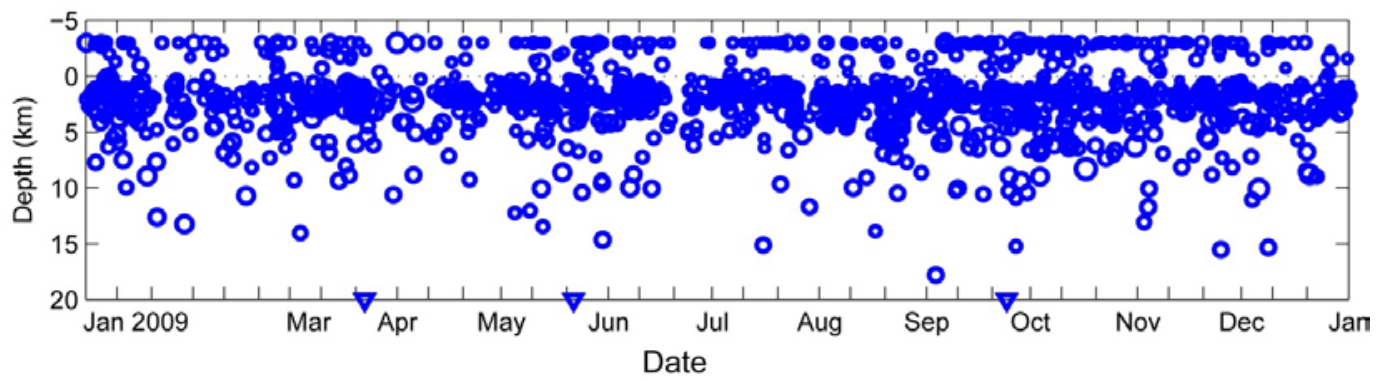

Figure A7. Summary plots of earthquakes located within the Katmai volcanic cluster in 2009. Open circles indicate hypocenters shallower than $20 \mathrm{~km}$ and open triangles indic ate hypocenters with depths of $20 \mathrm{~km}$ and deeper with symbols scaled with magnitude. Permanent seismograph stations are shown by open squares and labeled by station code. Solid triangles are used to show volcanic centers. Vertical exaggeration is x1.4. See appendix B for station information. 

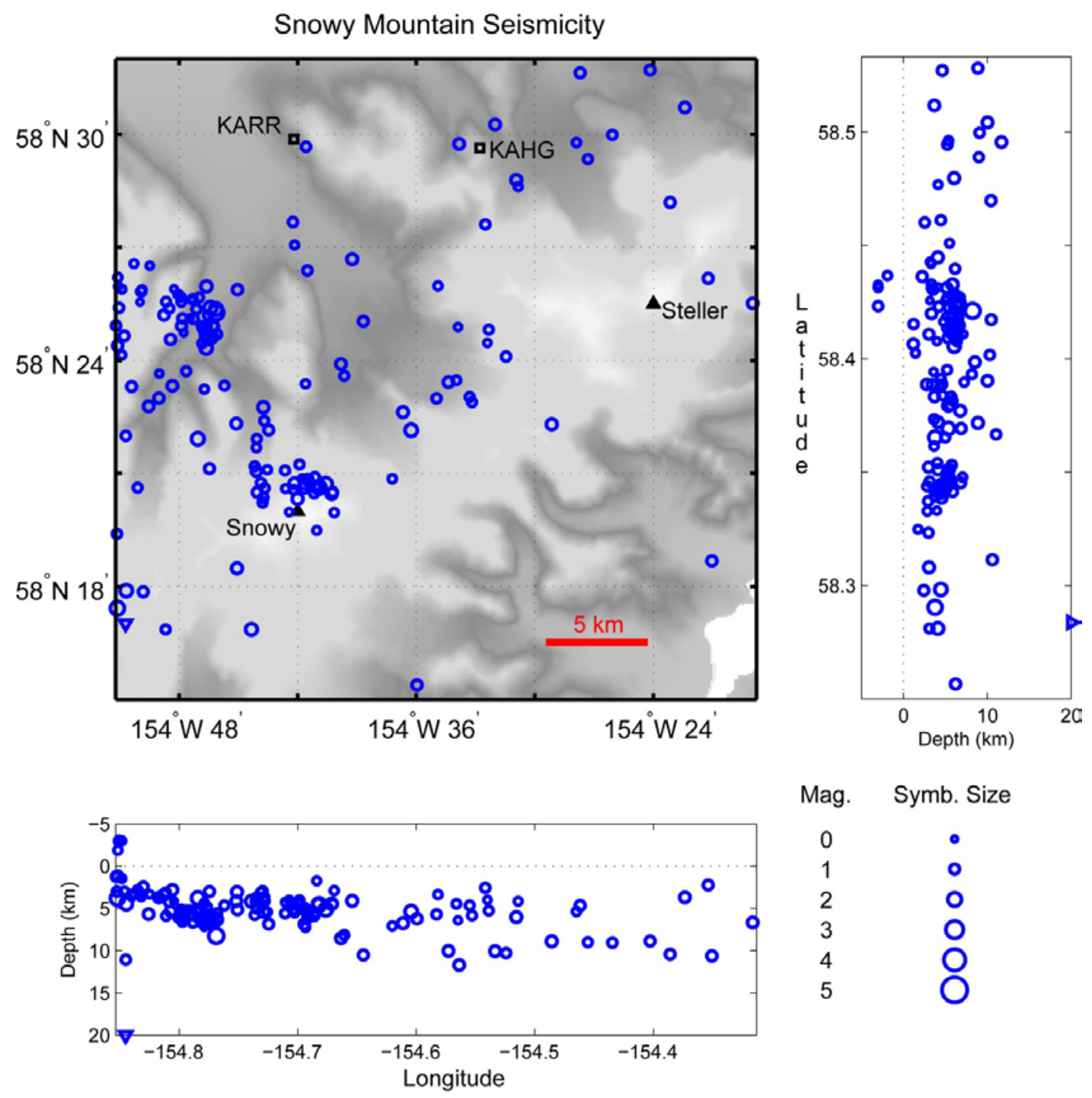

Mag. Symb. Size

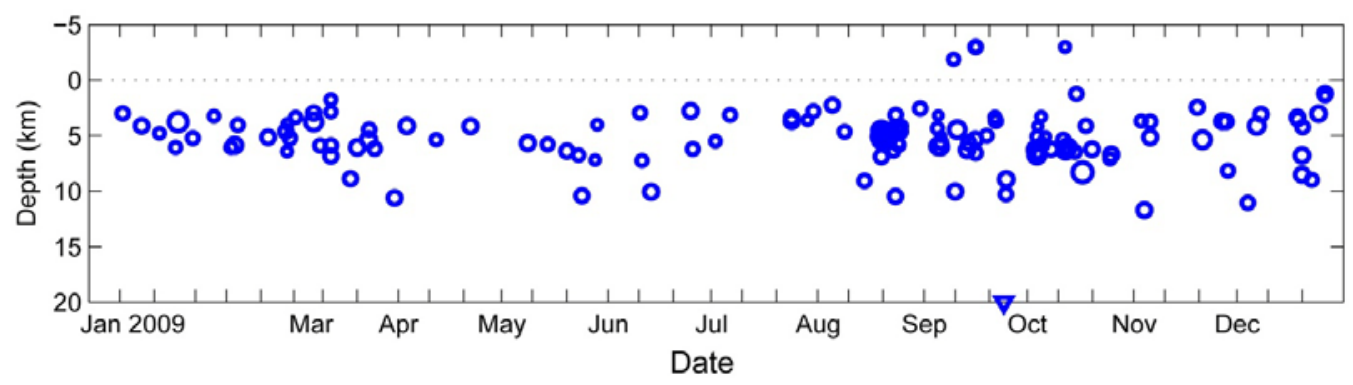

Figure A8. Summary plots of earthquakes located near Snowy Mountain in the Katmai volcanic cluster in 2009. Open circles show hypocenter locations shallower than $20 \mathrm{~km}$ and open triangles indicate times of hypocenters with depths of $20 \mathrm{~km}$ and deeper. Hypocenter symbols are scaled with magnitude. Permanent seismograph stations are shown by open squares and labeled by station code. Solid triangles are used to show volcanic centers. Vertical exaggeration is $\times 0.4$. See appendix B for station information. 
Mount Griggs Seismicity
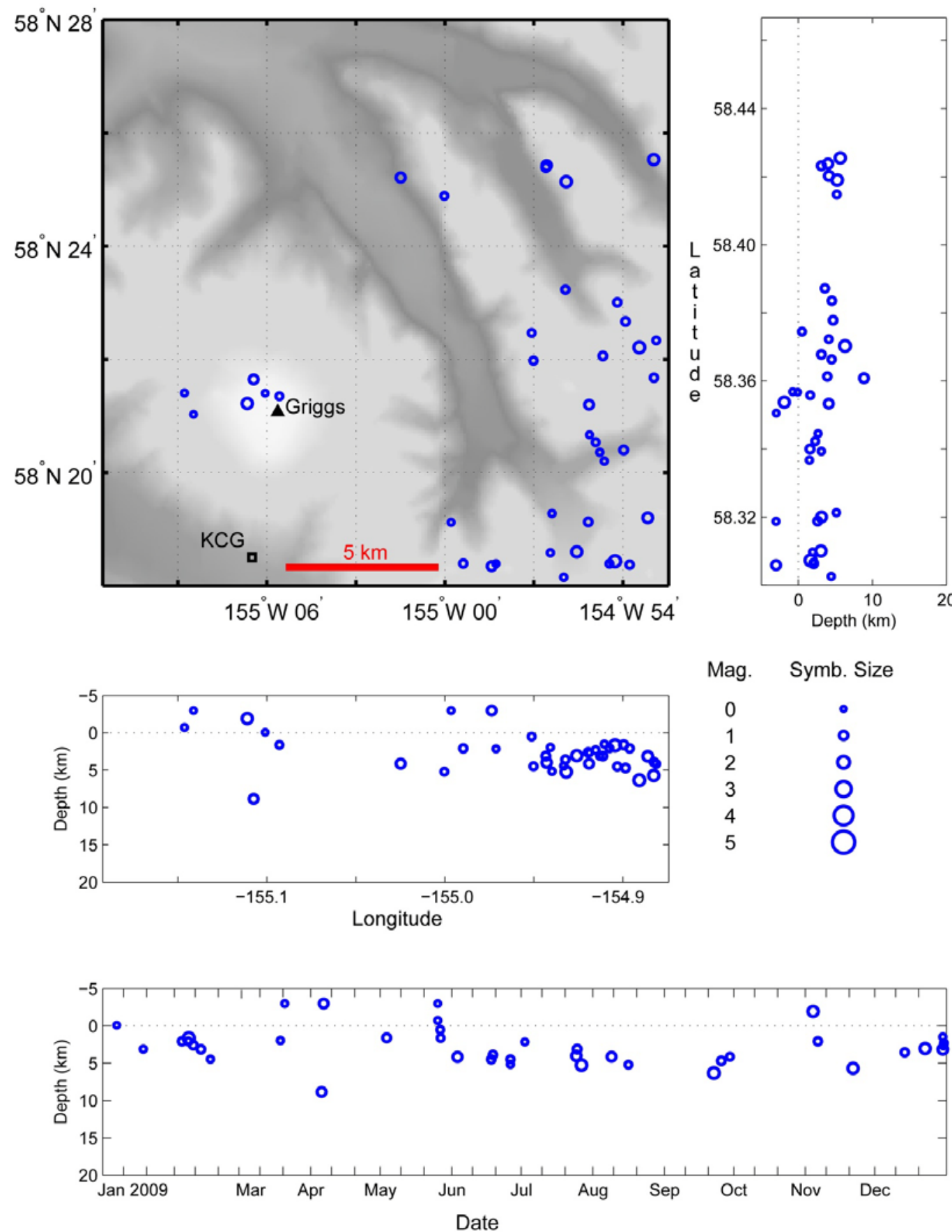

Figure A9. Summary plots of earthquakes located near Mount Griggs in the Katmai volcanic cluster in 2009. Open circles show hypocenter locations shallower than $20 \mathrm{~km}$. Hypocenter symbols are scaled with magnitude. Permanent seismograph stations are shown by open squares and labeled by station code. Solid triangles are used to show volc anic centers. Vertical exaggeration is $x 0.25$. See appendix $B$ for station information. Several earthquakes that appear on this figure appear on other figures. 

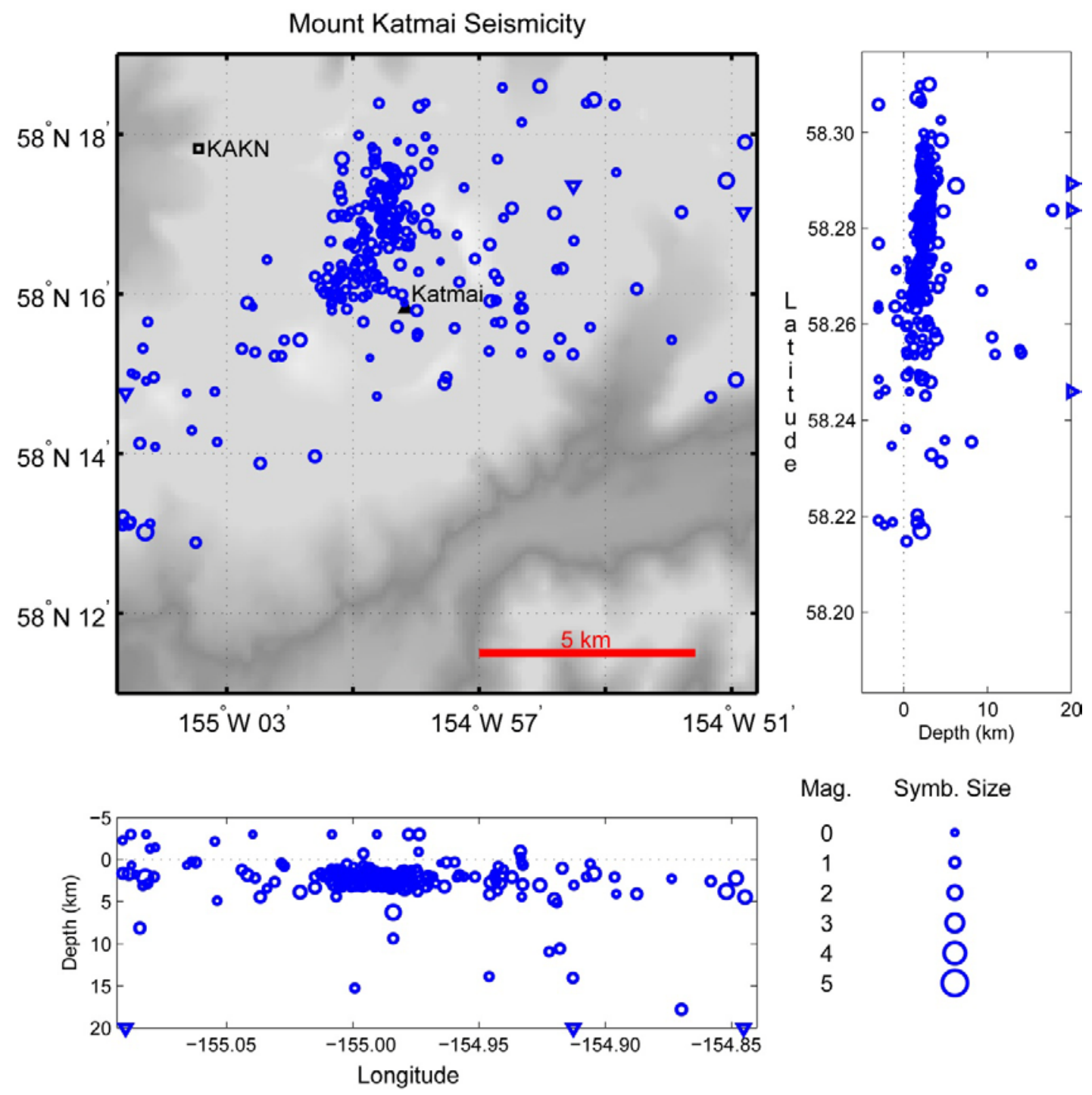

Mag. Symb. Size

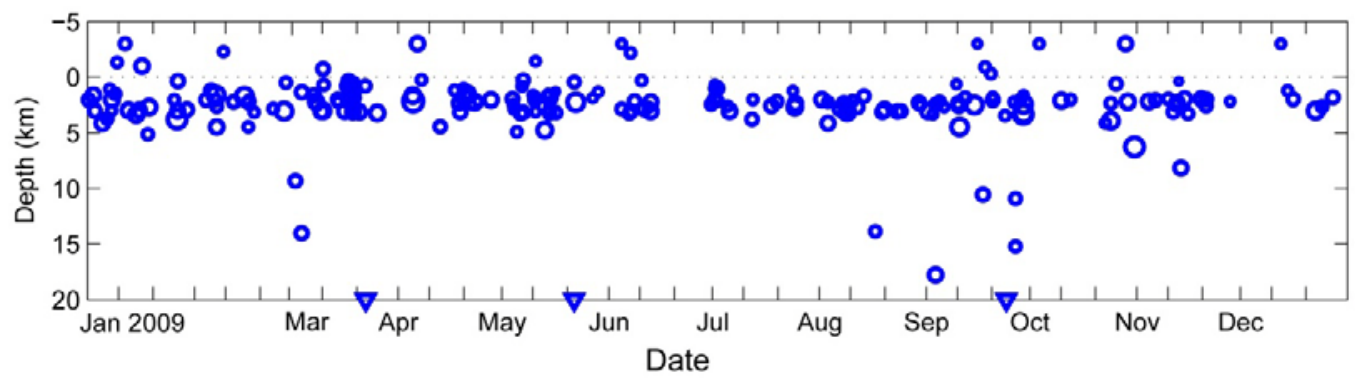

Figure A10. Summary plots of earthquakes located near Mount Katmai in the Katmai volcanic cluster in 2009. Open circles show hypocenter locations shallower than $20 \mathrm{~km}$ and open triangles indicate hypocenters with depths of $20 \mathrm{~km}$ and deeper. Hypocenter symbols are scaled with magnitude Permanent seismograph stations are shown by open squares and labeled by station code. Solid triangles are used to show volcanic centers. Vertical exaggeration is $\times 0.2$. See appendix $B$ for station information. Several earthquakes that appear on this figure appear on other figures. 

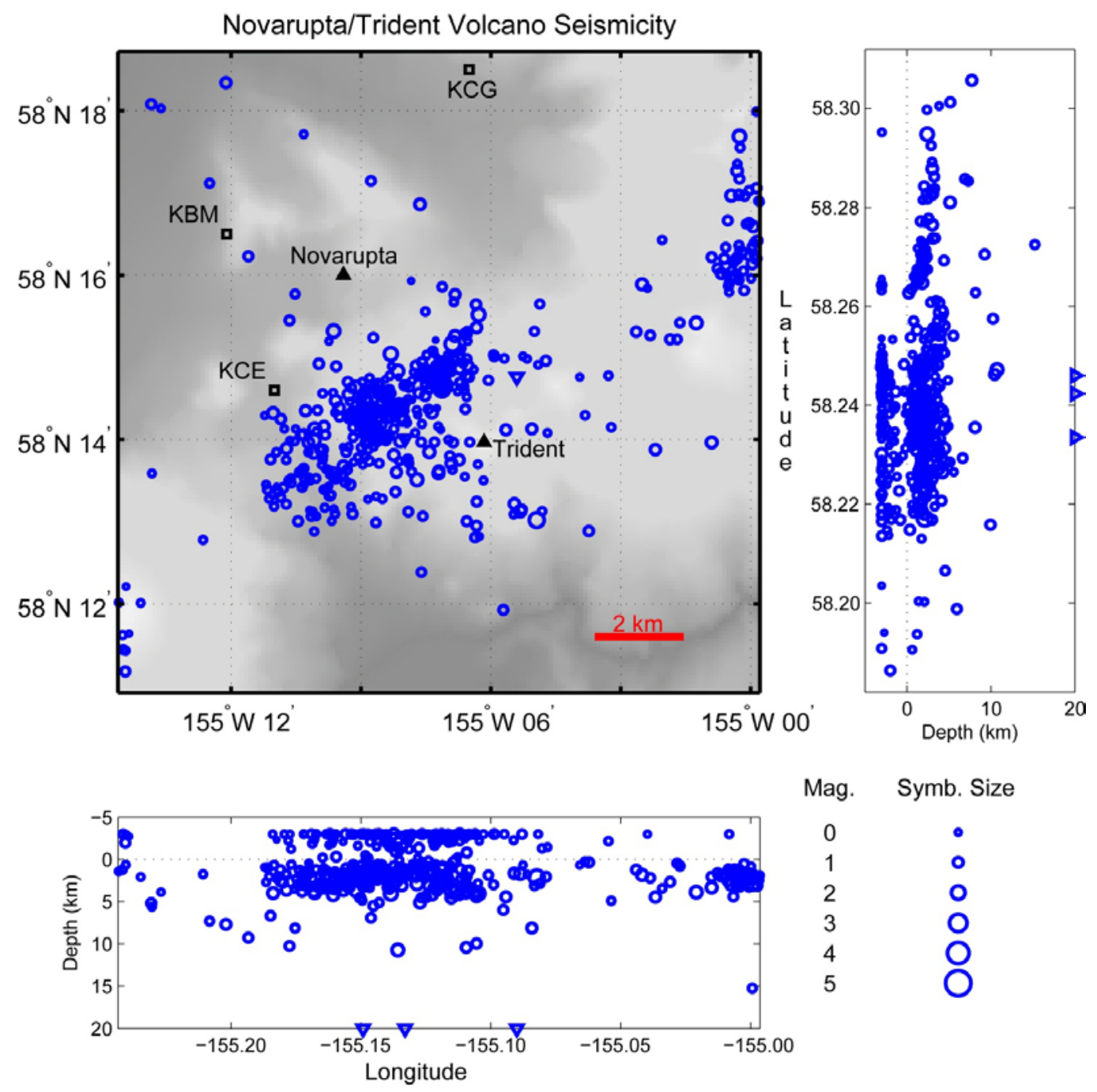

Mag. Symb. Size

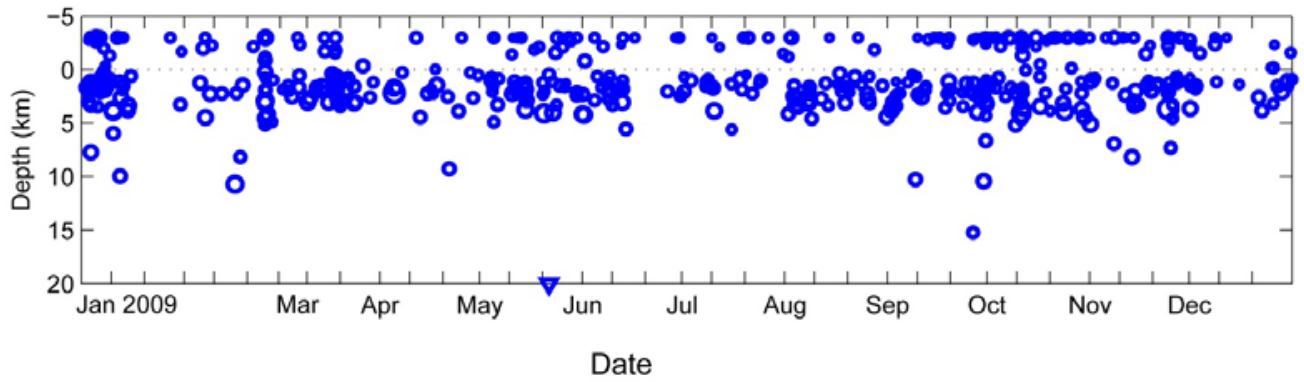

Figure A11. Summary plots of earthquakes located near Novarupta and Trident Volcano in the Katmai volcanic cluster in 2009. Open circles show hypocenter locations shallower than $20 \mathrm{~km}$ and open triangles indicate hypocenters with depths of $20 \mathrm{~km}$ and deeper. Hypocenter symbols are scaled with magnitude. Permanent seismograph stations are shown by open squares and labeled by station code. Solid triangles are used to show volc anic centers. Vertical exaggeration is $x 0.2$. See appendix B for station information. Several earthquakes that appear on this figure appear on other figures. 


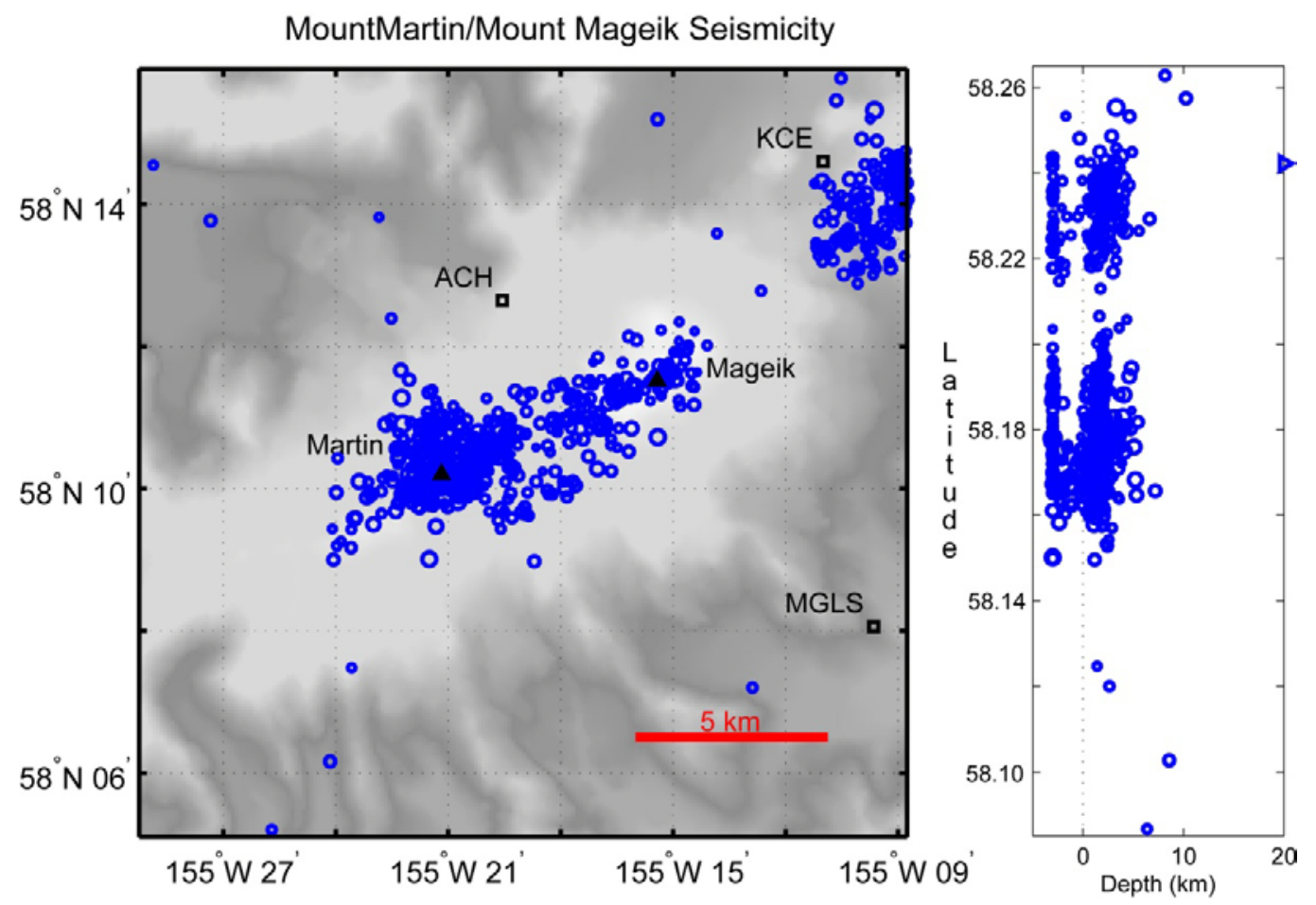

Mag. Symb. Size

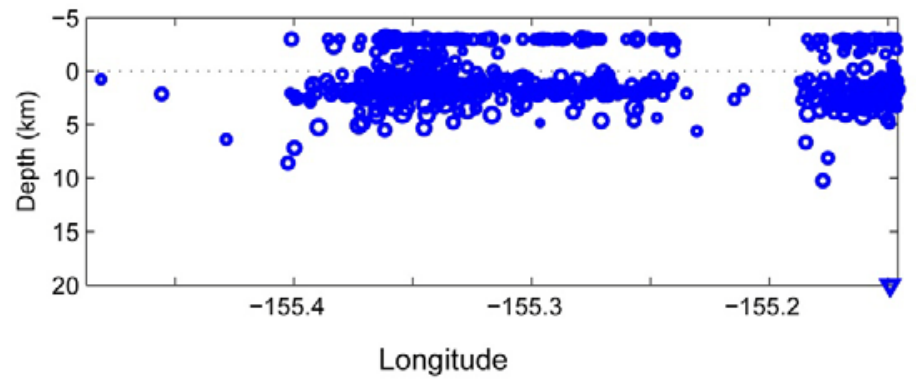

$\circ$
$\circ$
0
0
0
0

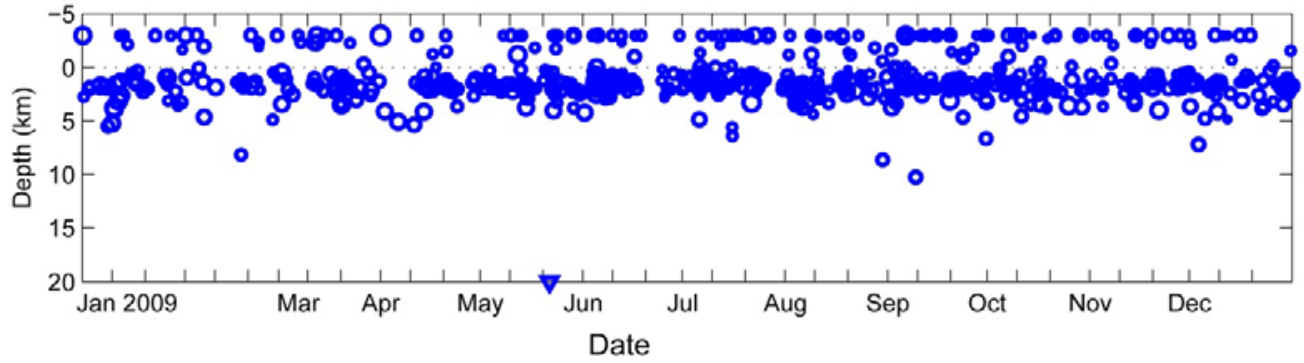

Figure A12. Summary plots of earthquakes located near Mount Mageik and Mount Martin in the Katmai volcanic cluster in 2009. Open circles show hypocenter locations shallower than $20 \mathrm{~km}$ and open triangles indicate hypocenters with depths of $20 \mathrm{~km}$ and deeper. Hypocenter symbols are scaled with magnitude. Permanent seismograph stations are shown by open squares and labeled by station code. Solid triangles are used to show volc anic centers. Vertical exaggeration is $x 0.25$. See appendix $B$ for station information. Several earthquakes that appear on this figure appear on other figures. 

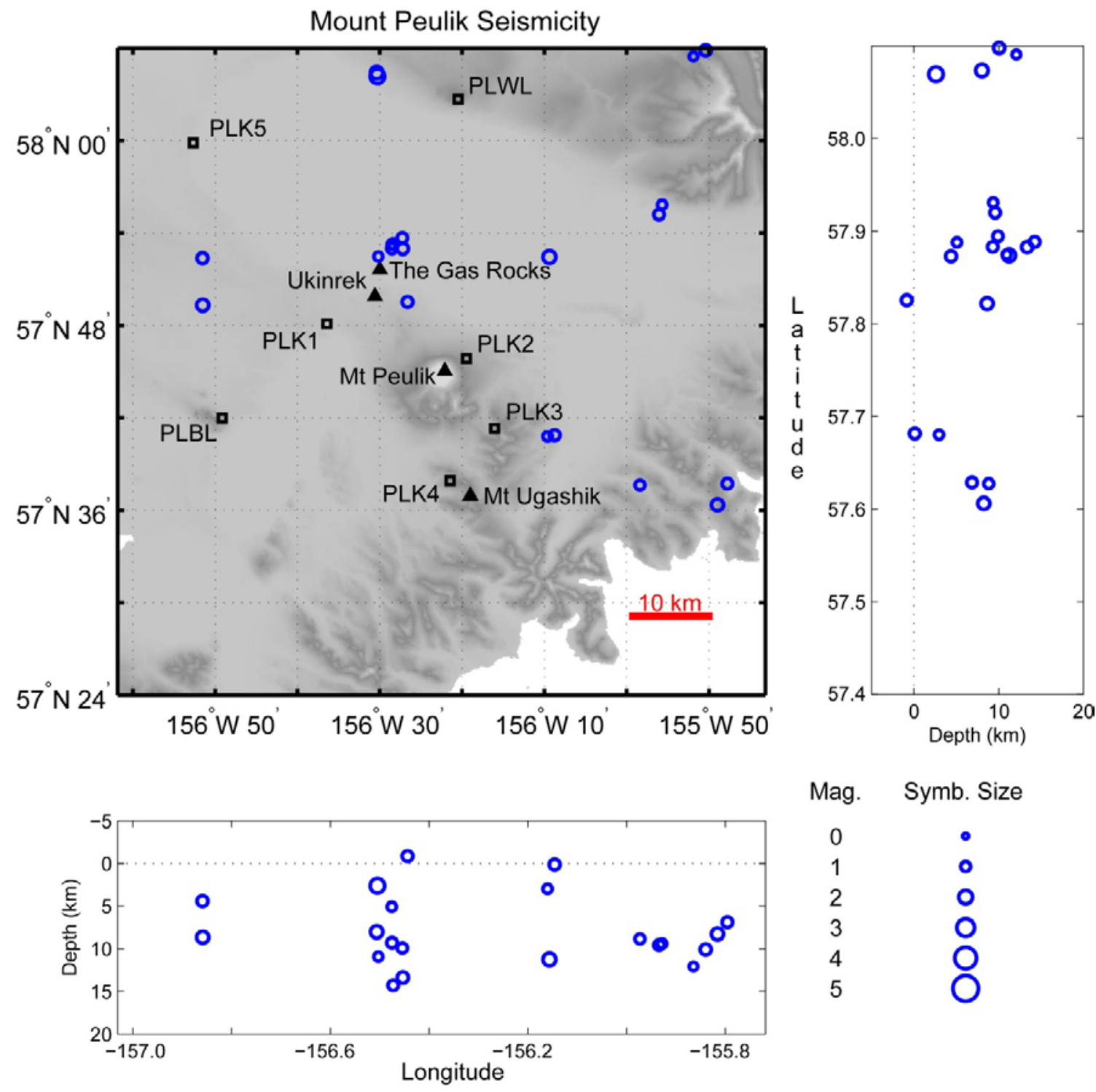

Mag. Symb. Size
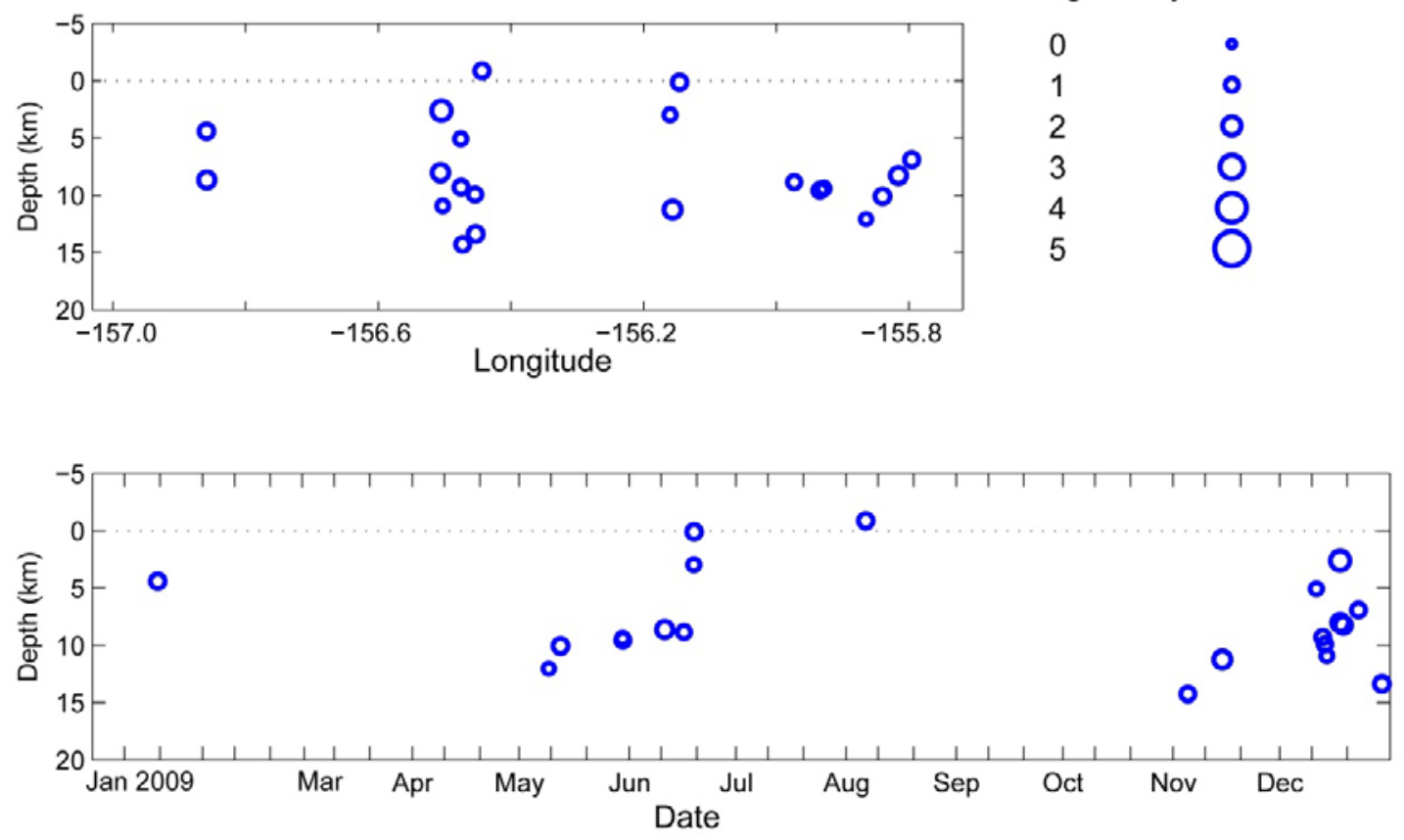

Figure A13. Summary plots of earthquakes located near Mount Peulik in 2009. Open circles indicate hypocenters shallower than $20 \mathrm{~km}$ with symbols scaled with magnitude. Permanent seismograph stations are shown by open squares and labeled by station code. Solid triangles are used to show volcanic centers. Vertical exaggeration is $\mathrm{x1.0}$. See appendix B for station information. 

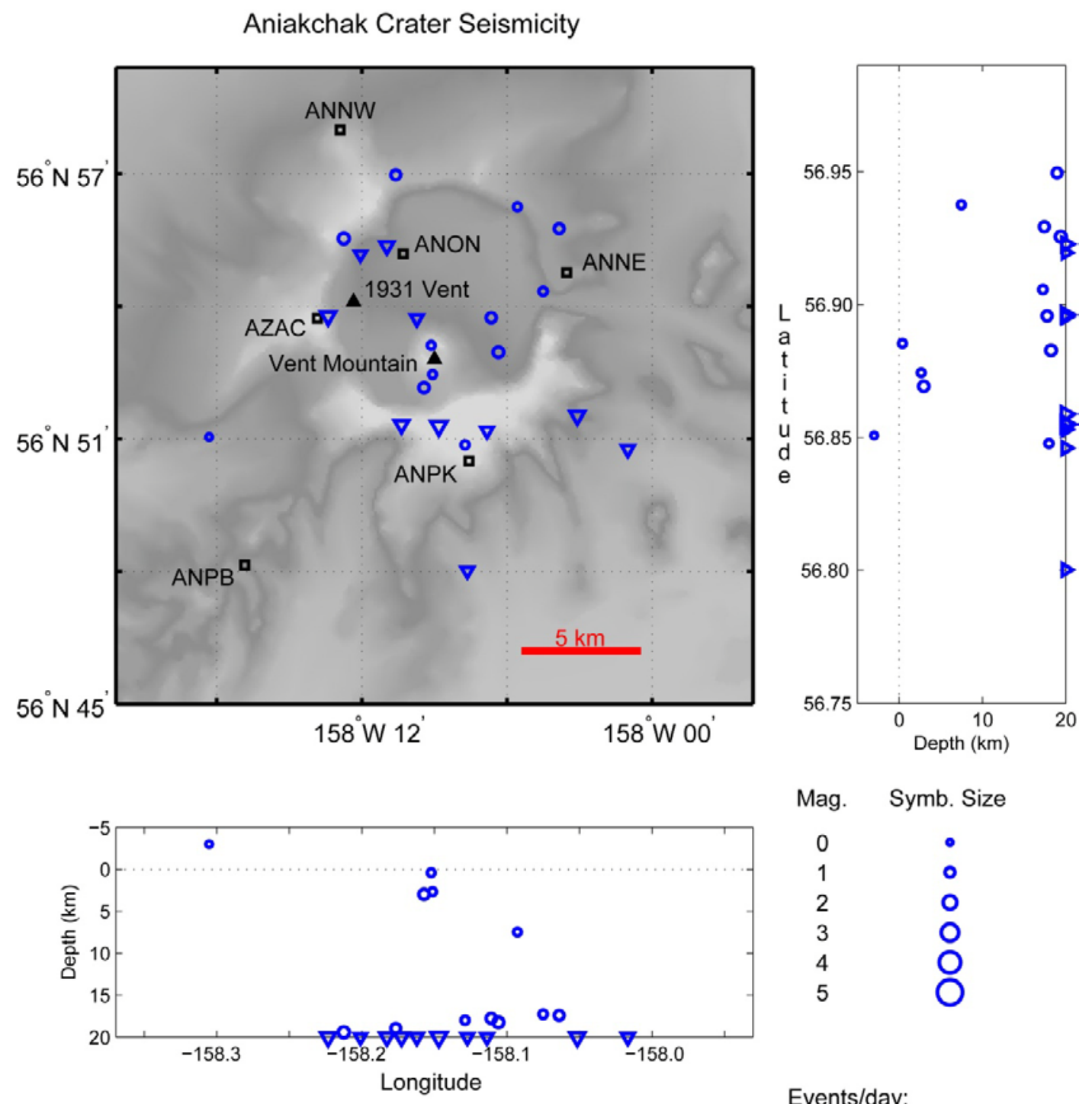

Mag. Symb. Size

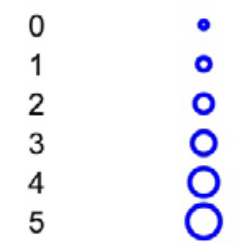

Events/day:

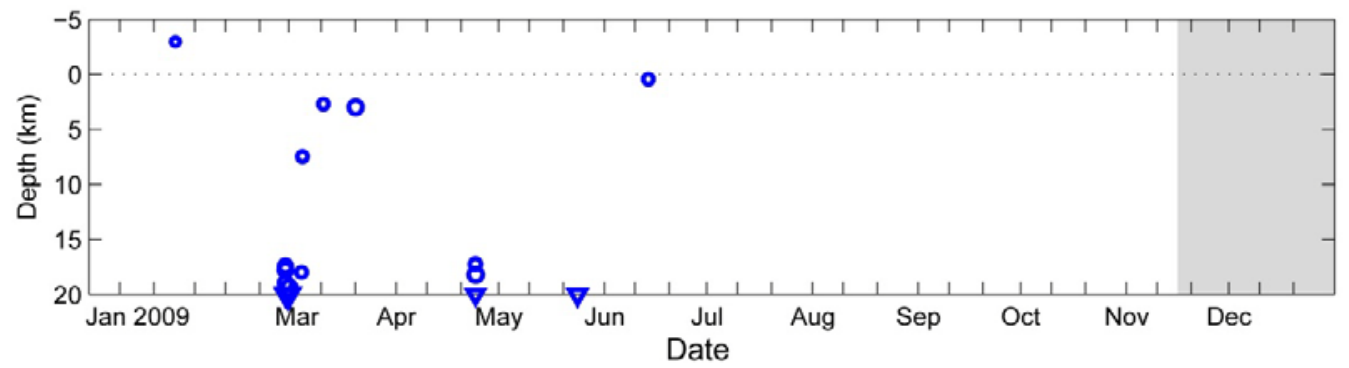

Figure A14. Summary plots of earthquakes located near Aniakchak Crater in 2009. Open circles indicates hypocenters shallower than $20 \mathrm{~km}$ and open triangles indicate hypocenters with depths of $20 \mathrm{~km}$ and deeper with symbols scaled with magnitude. Permanent seismograph stations are shown by open squares and labeled by station code. The gray shaded area in time depth plot shows the time frame the subnetwork was not on the monitored volcano list. Solid triangles are used to show volcanic centers. Vertical exaggeration is $\times 0.35$. See appendix B for station information. 

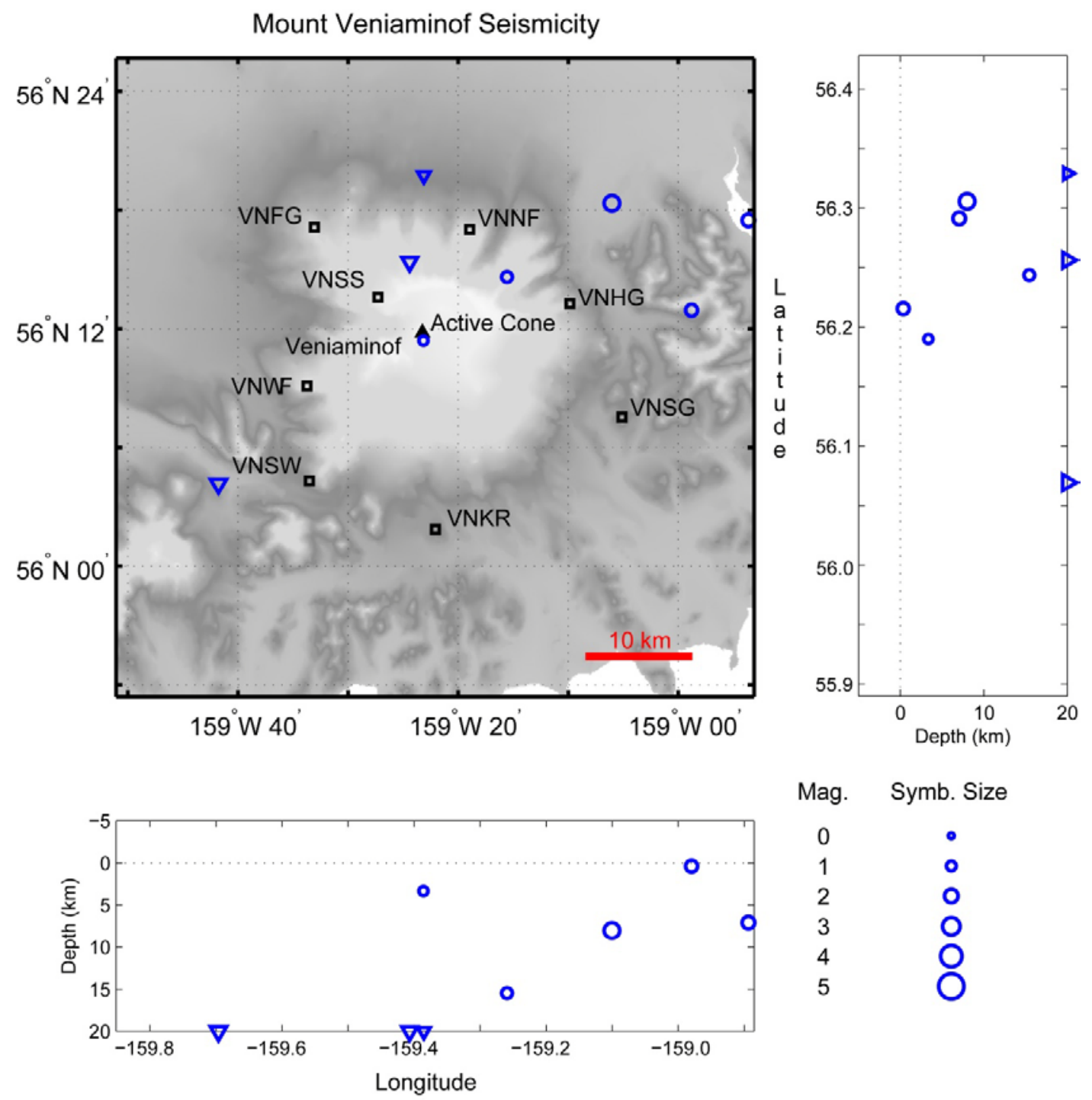

Mag. Symb. Size
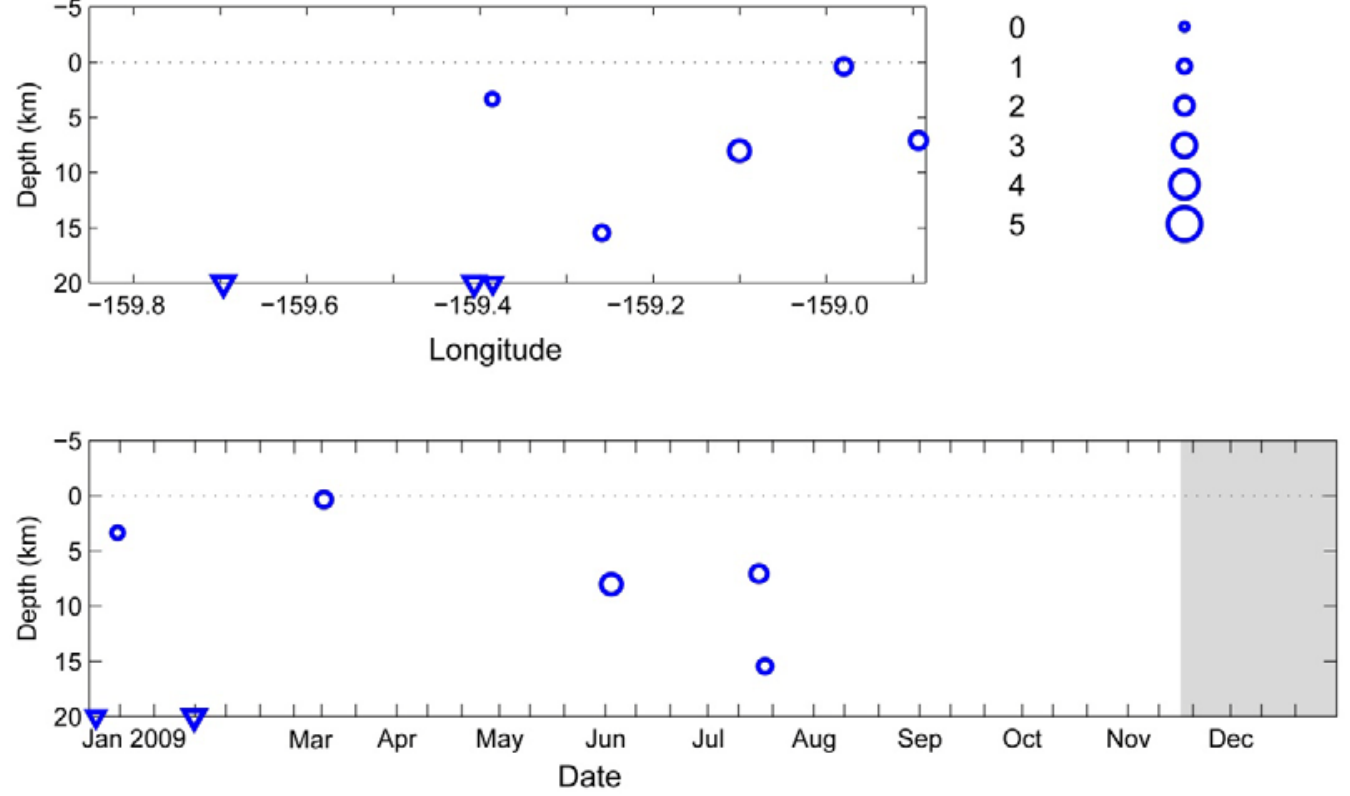

Figure A15. Summary plots of earthquakes located near Mount Veniaminof in 2009. Open circles show hypocenter locations shallower than $20 \mathrm{~km}$ and open triangles indicates hypocenters with depths of $20 \mathrm{~km}$ and deeper. Permanent seismograph stations are shown by open squares and labeled by station code. The gray shaded area in time depth plot shows the time frame the subnetwork was not on the monitored volcano list. Solid triangles are used to show volcanic centers. Vertical exaggeration is $\mathrm{x} 0.8$. See appendix $B$ for station information. 

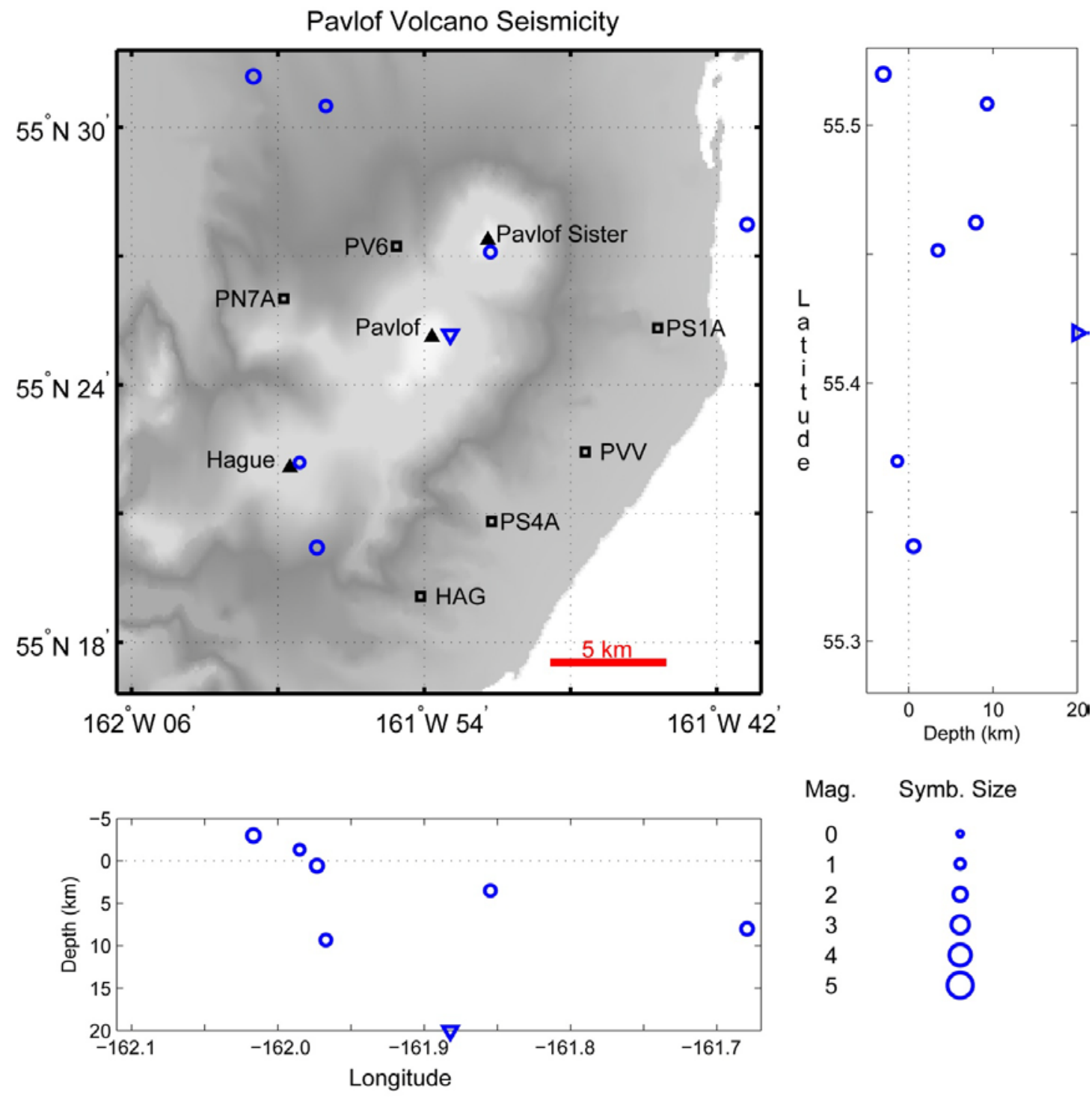

Mag. Symb. Size

$\begin{array}{ll}0 & \circ \\ 1 & 0 \\ 2 & 0 \\ 3 & \bigcirc \\ 4 & \bigcirc \\ 5 & \bigcirc\end{array}$

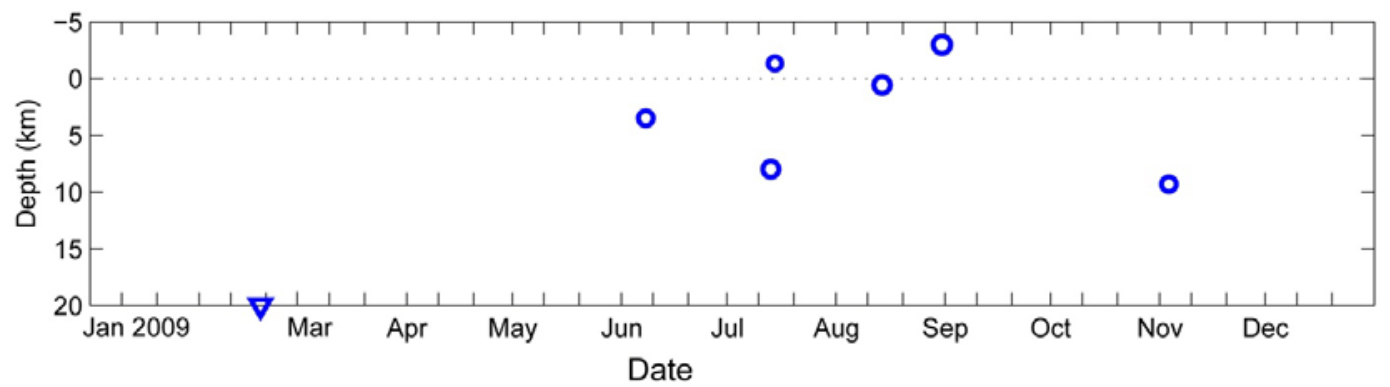

Figure A16. Summary plots of earthquakes located near Pavlof Volcano in 2009. Open circles indicate hypocenters shallower than $20 \mathrm{~km}$ and open triangles indicate hypocenters with depths of $20 \mathrm{~km}$ and deeper with symbols scaled with magnitude. Permanent seismograph stations are shown by open squares and labeled by station code. Solid triangles are used to show volcanic centers. Vertical exaggeration is $\mathrm{x} 0.35$. See appendix $\mathrm{B}$ for station information. 
Mount Dutton Seismicity

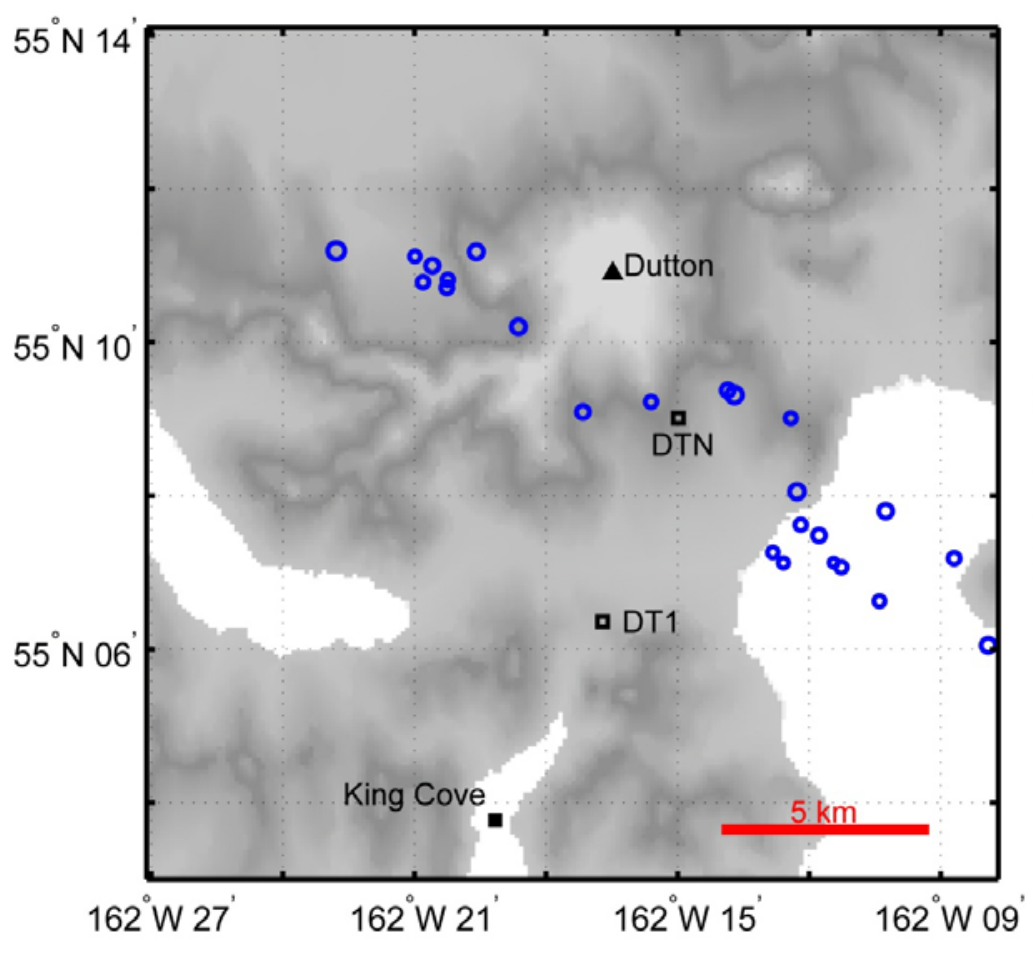

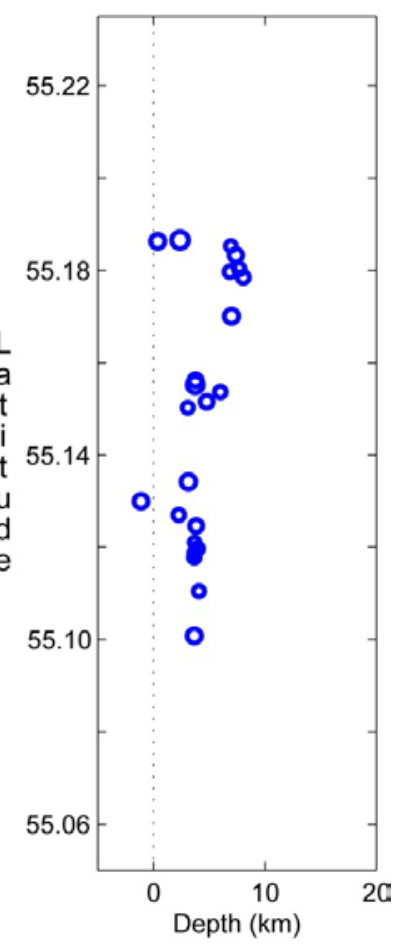

Mag. Symb. Size
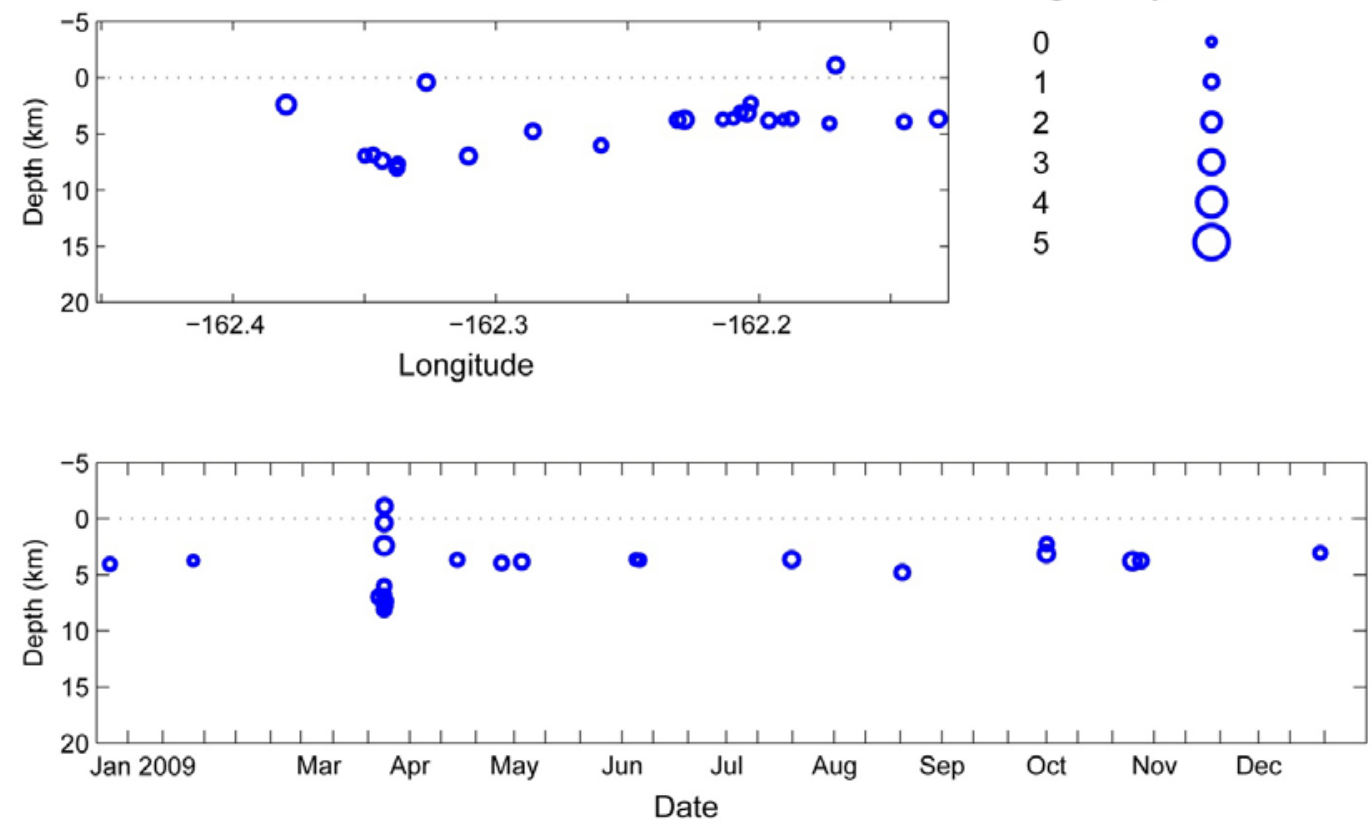

Figure A17. This summary plot shows earthquakes located near Mount Dutton in 2009. Open circles show hypocenter locations shallower than $20 \mathrm{~km}$. Hypocenter symbols are scaled with magnitude. Permanent seismograph stations are shown by open squares and labeled by station code. Solid triangles are used to show volcanic centers and solid squares are used to show other points of interest. Vertical exaggeration is $\mathrm{x} 0.3$. See appendix B for station information. 
Unimak Island Seismicity
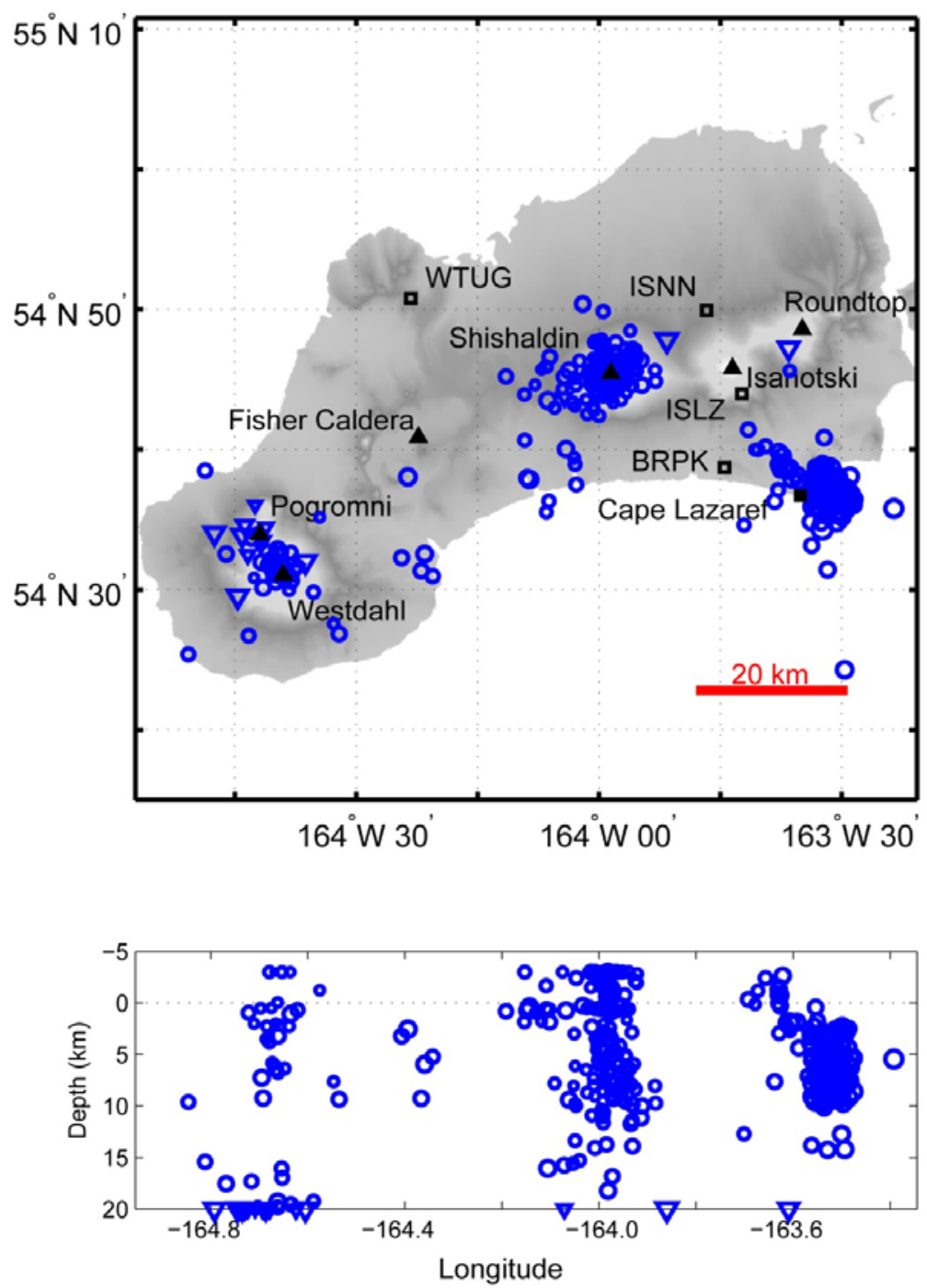

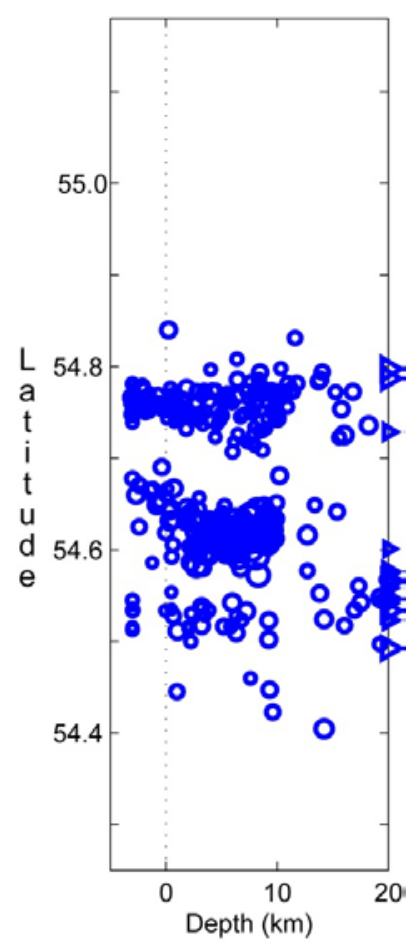

Mag. Symb. Size

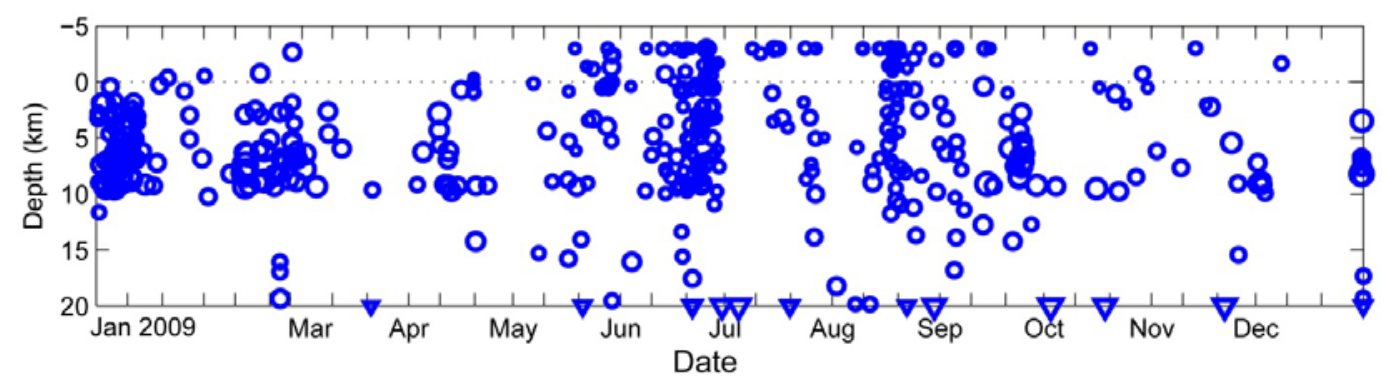

Figure A18. Summary plots of earthquakes located near Unimak Island in 2009. Open circles indicates hypocenters shallower than $20 \mathrm{~km}$ and open triangles indicates hypocenters with depths of $20 \mathrm{~km}$ and deeper with symbols scaled with magnitude. Permanent seismograph stations are shown by open squares and labeled by station code. Solid triangles are used to show volcanic centers. Vertical exaggeration is $\times 1.4$. See appendix B for station information. 

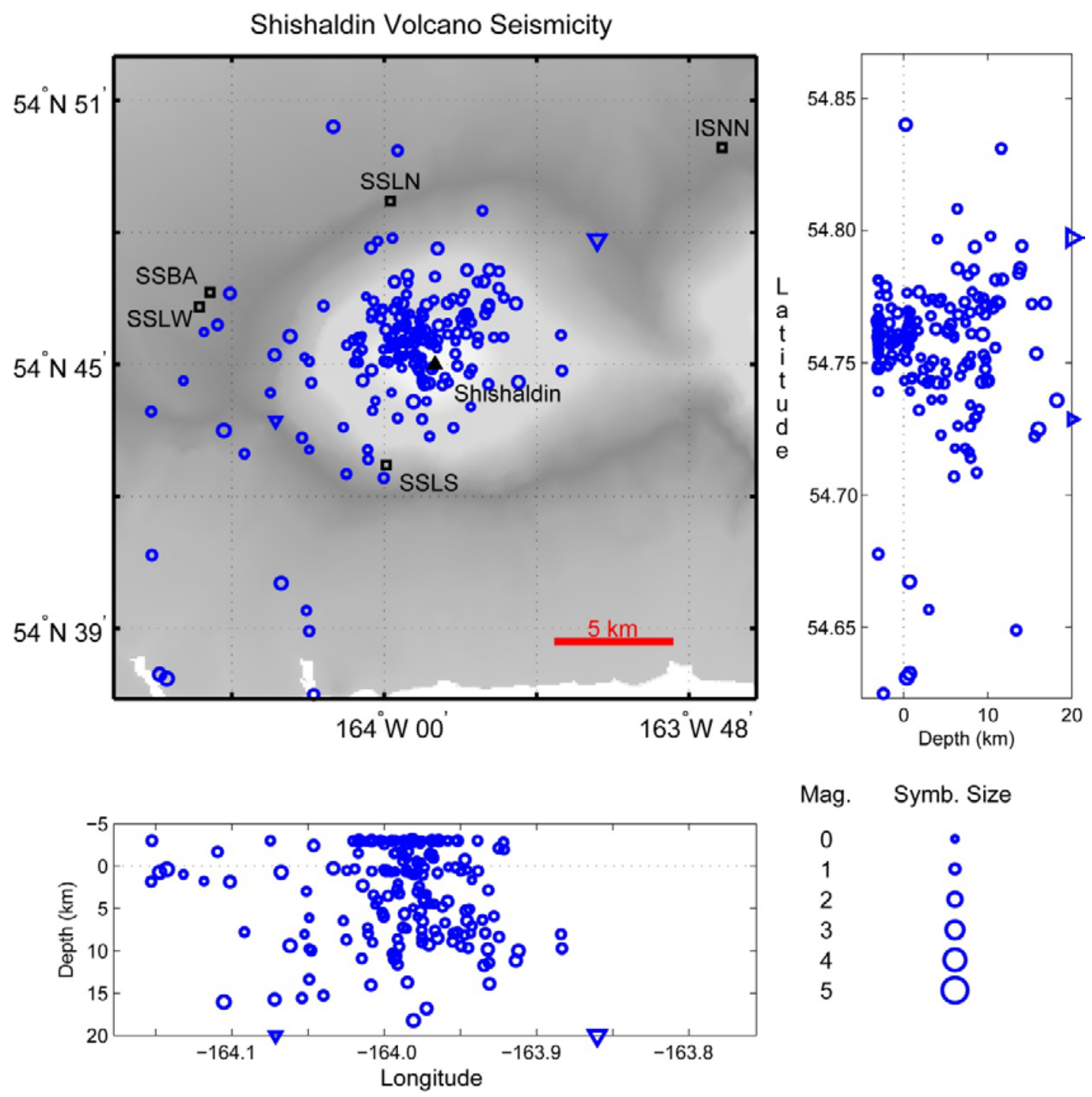

Mag. Symb. Size

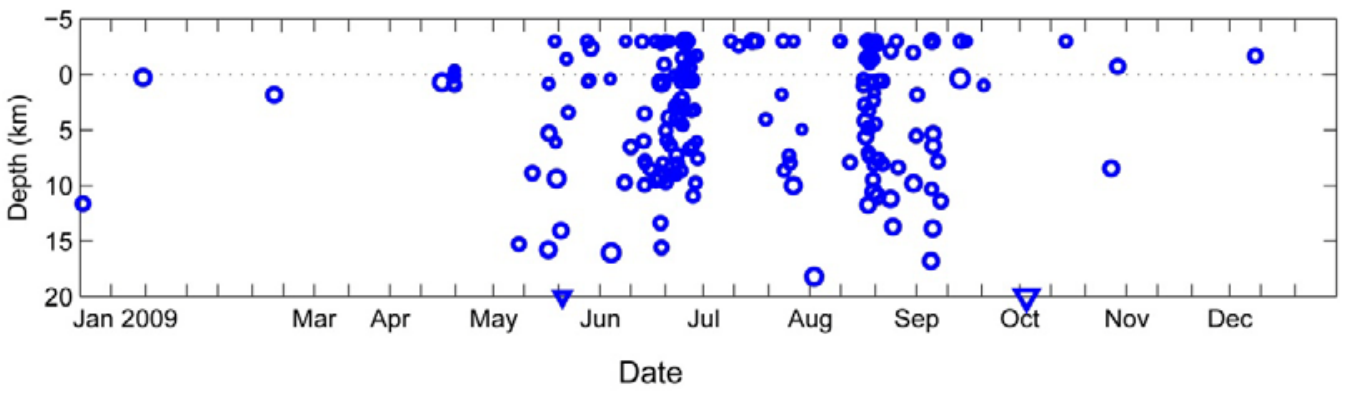

Figure A19. Summary plots of earthquakes located near Shishaldin Volcano in 2009. Open circles indicate hypocenters shallower than $20 \mathrm{~km}$ and open triangles indicate hypocenters with depths of $20 \mathrm{~km}$ and deeper with symbols scaled with magnitude. Permanent seismograph stations are shown by open squares and labeled by station code. Solid triangles are used to show volcanic centers. Vertical exaggeration is $\mathrm{x} 0.35$. See appendix $\mathrm{B}$ for station information. 

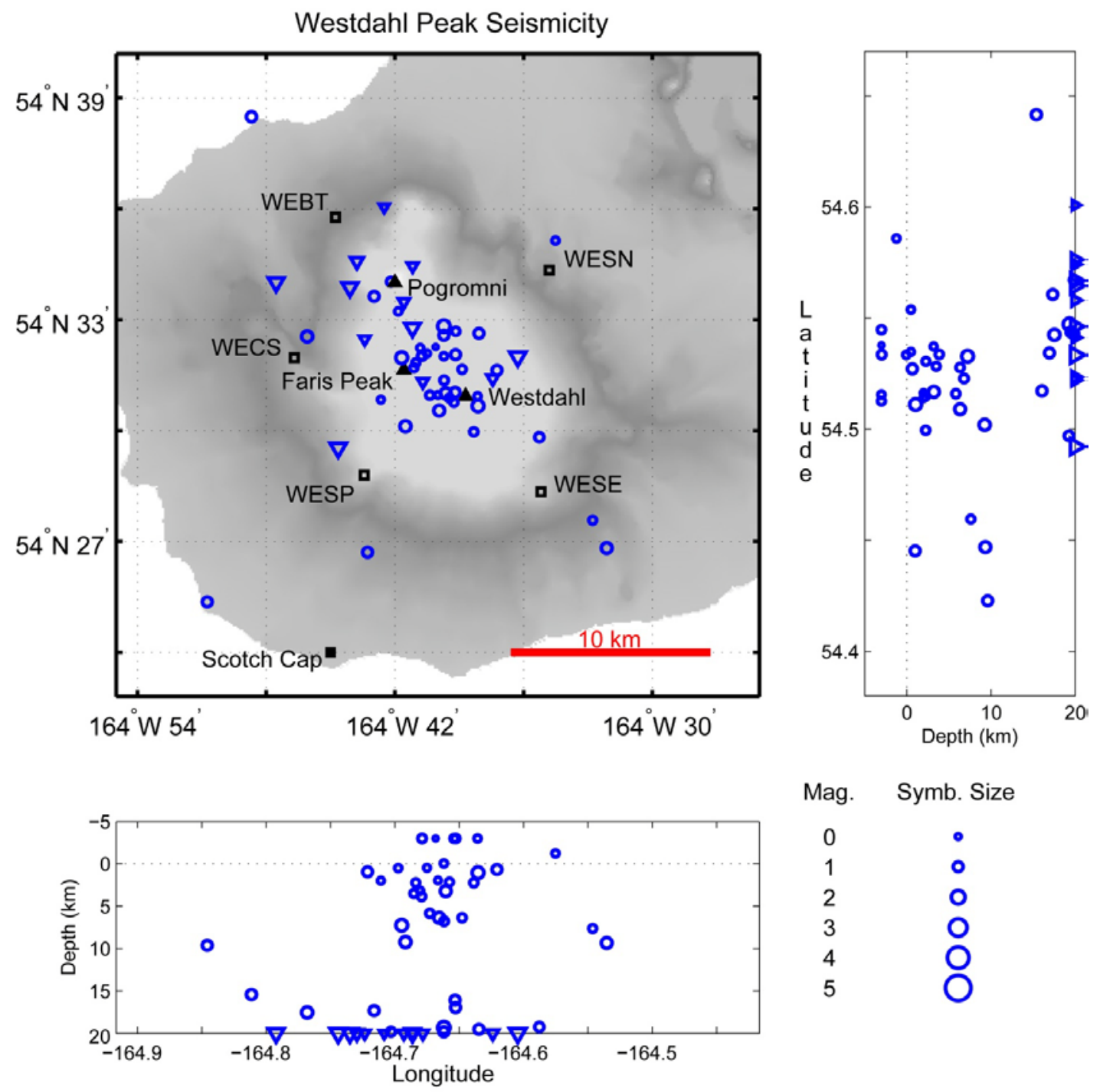

Mag. Symb. Size

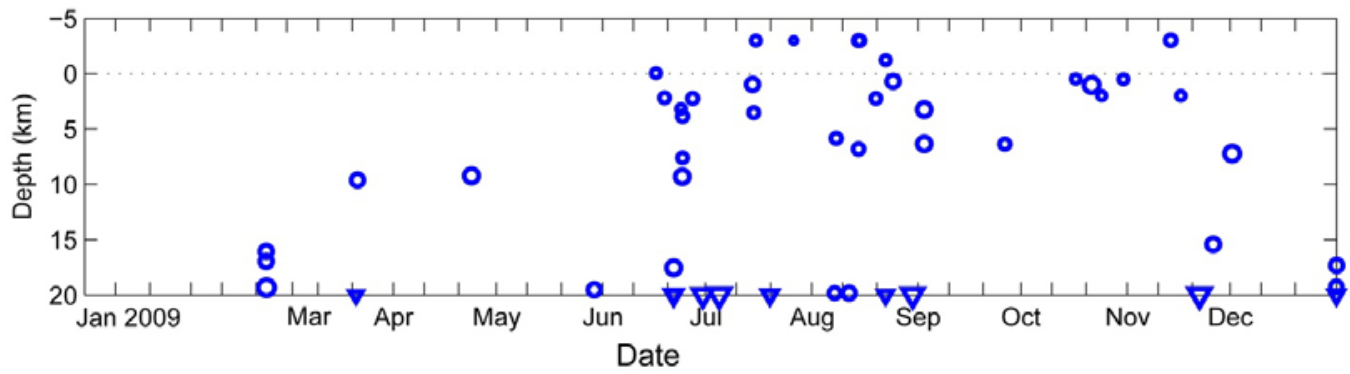

Figure A20. Summary plots of earthquakes located near Westdahl Peak in 2009. Open circles show hypocenter locations shallower than $20 \mathrm{~km}$ and open triangles indicate hypocenters with depths of $20 \mathrm{~km}$ and deeper. Hypocenter symbols are scaled with magnitude. Permanent seismograph stations are shown by open squares and labeled by station code. Solid triangles are used to show volcanic centers and solid squares are used to show other points of interest. Vertical exaggeration is $x$.4. See appendix $B$ for station information. 

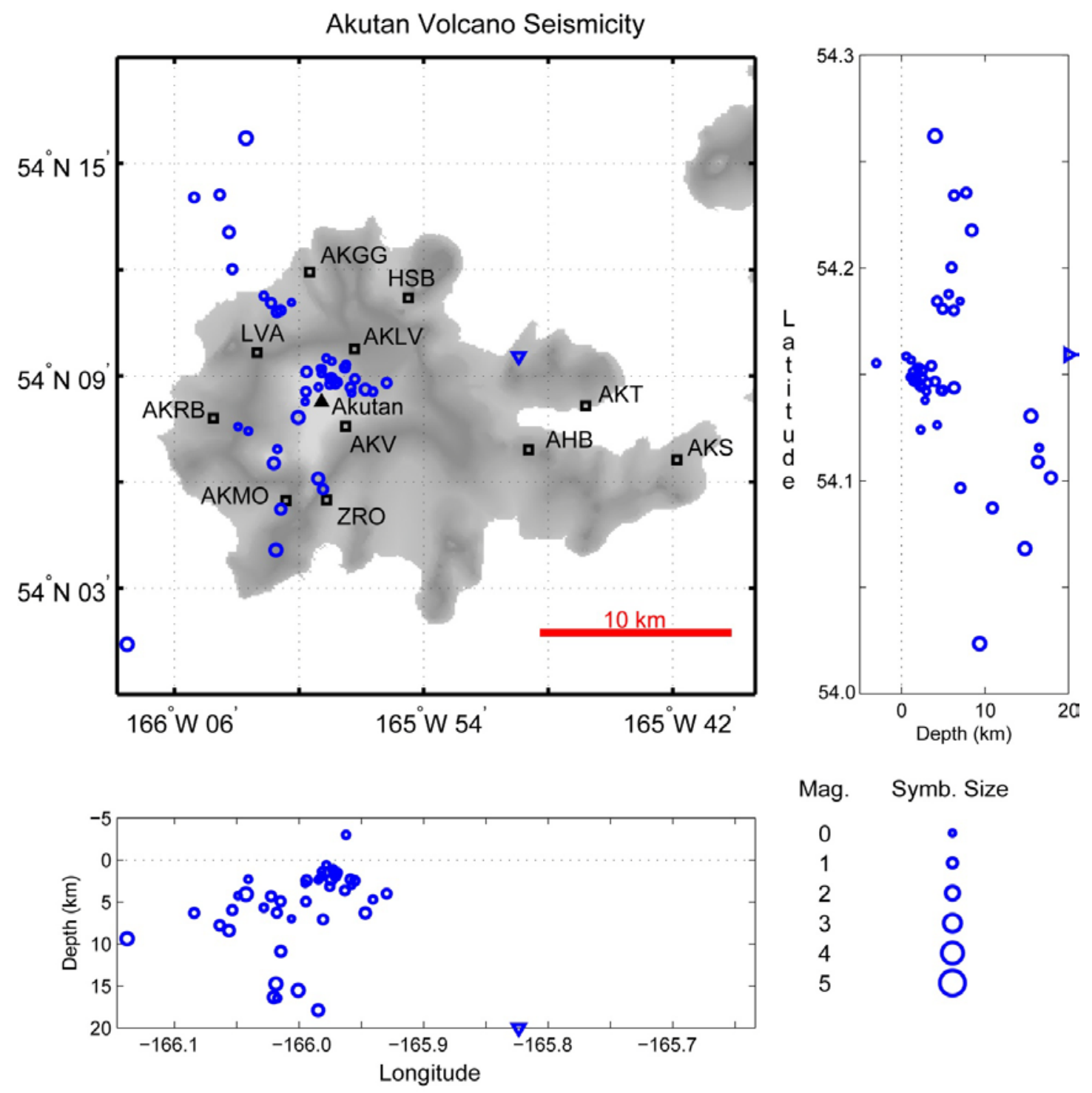

Mag. Symb. Size
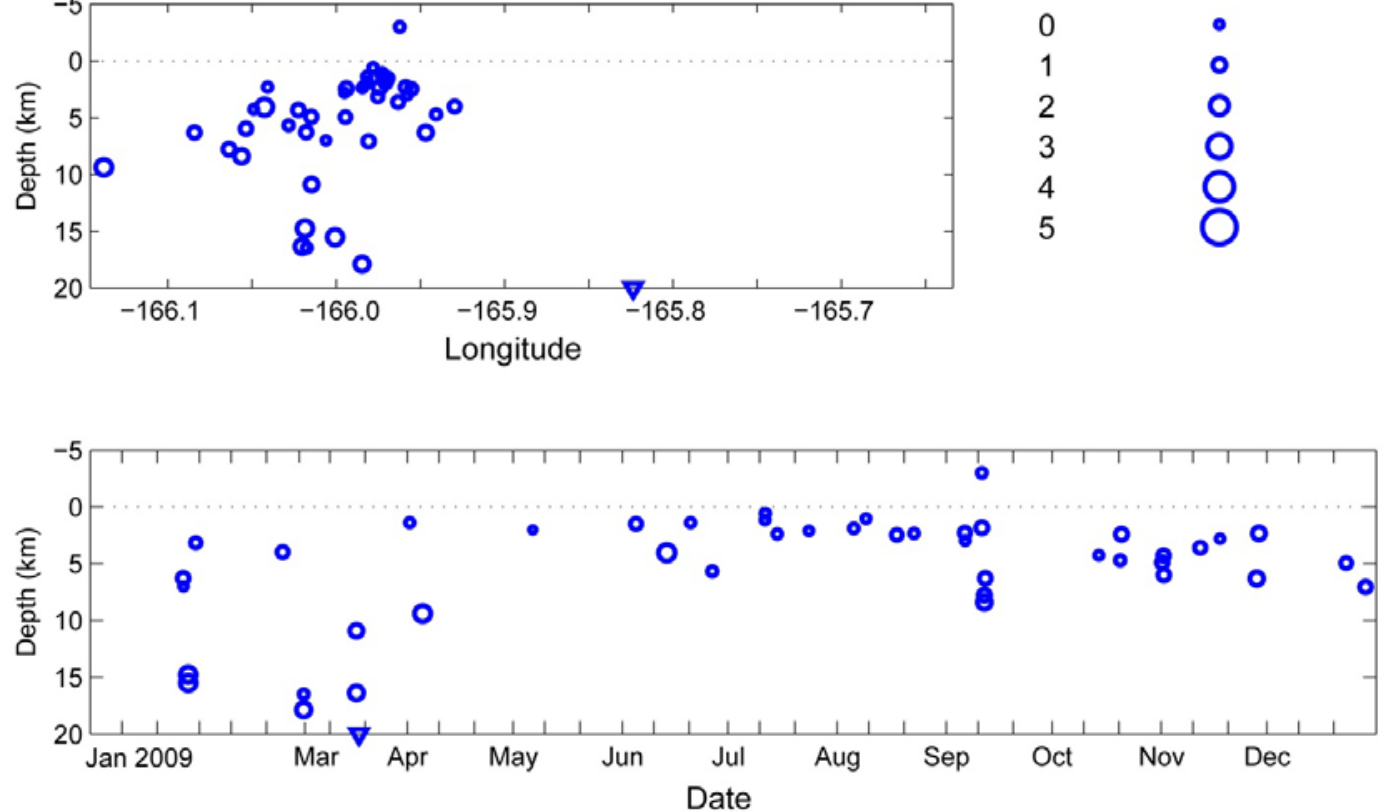

Figure A21. Summary plots of earthquakes located near Akutan Peak in 2009. Open circles indicate hypocenters shallower than $20 \mathrm{~km}$ and open triangles indicates hypocenters with depths of $20 \mathrm{~km}$ and deeper with symbols scaled with magnitude. Permanent seismograph stations are shown by open squares and labeled by station code. Solid triangles are used to show volcanic centers. Vertical exaggeration is $x 0.45$. See appendix $B$ for station information. 

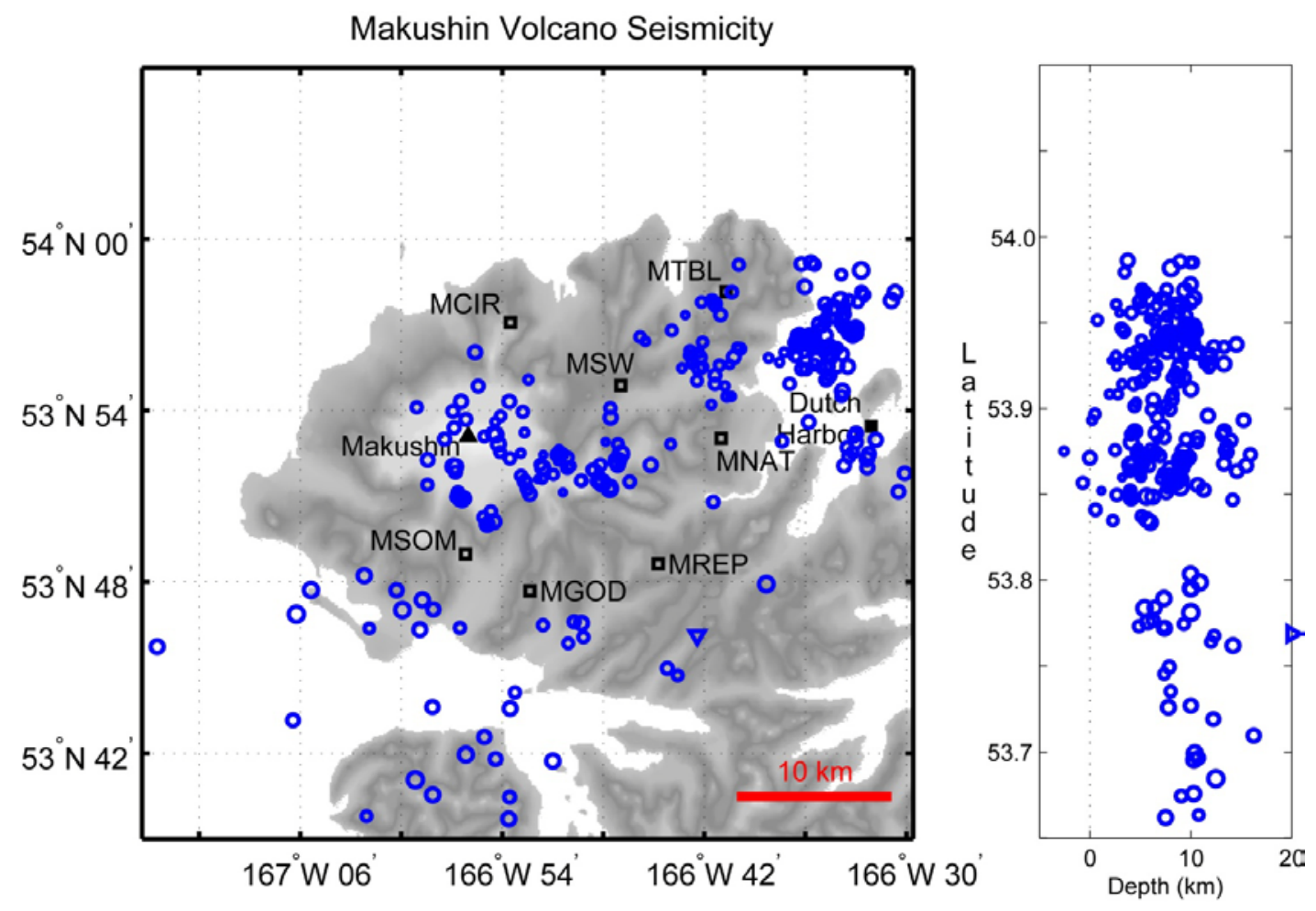

Mag. Symb. Size
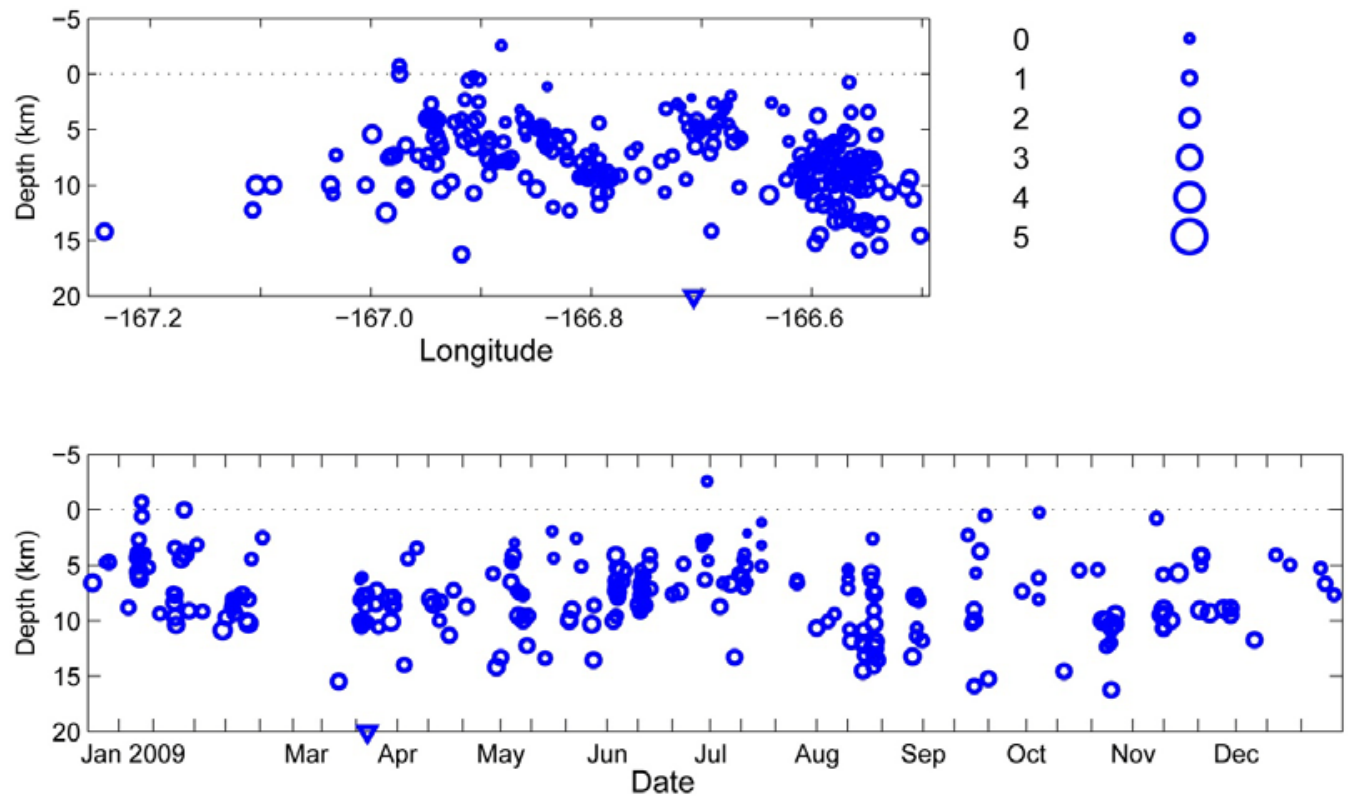

Figure A22. Summary plots of earthquakes located near Makushin Volcano in 2009. Open circles show hypocenter locations shallower than $20 \mathrm{~km}$ and open triangle indicate hypocenters with depths of $20 \mathrm{~km}$ and deeper. Hypocenter symbols are scaled with magnitude. Permanent seismograph stations are shown by open squares and labeled by station code. Solid triangles are used to show volcanic centers and solid squares are used to show other points of interest. Vertical exaggeration is $\mathrm{x} 0.7$. See appendix $\mathrm{B}$ for station information. 

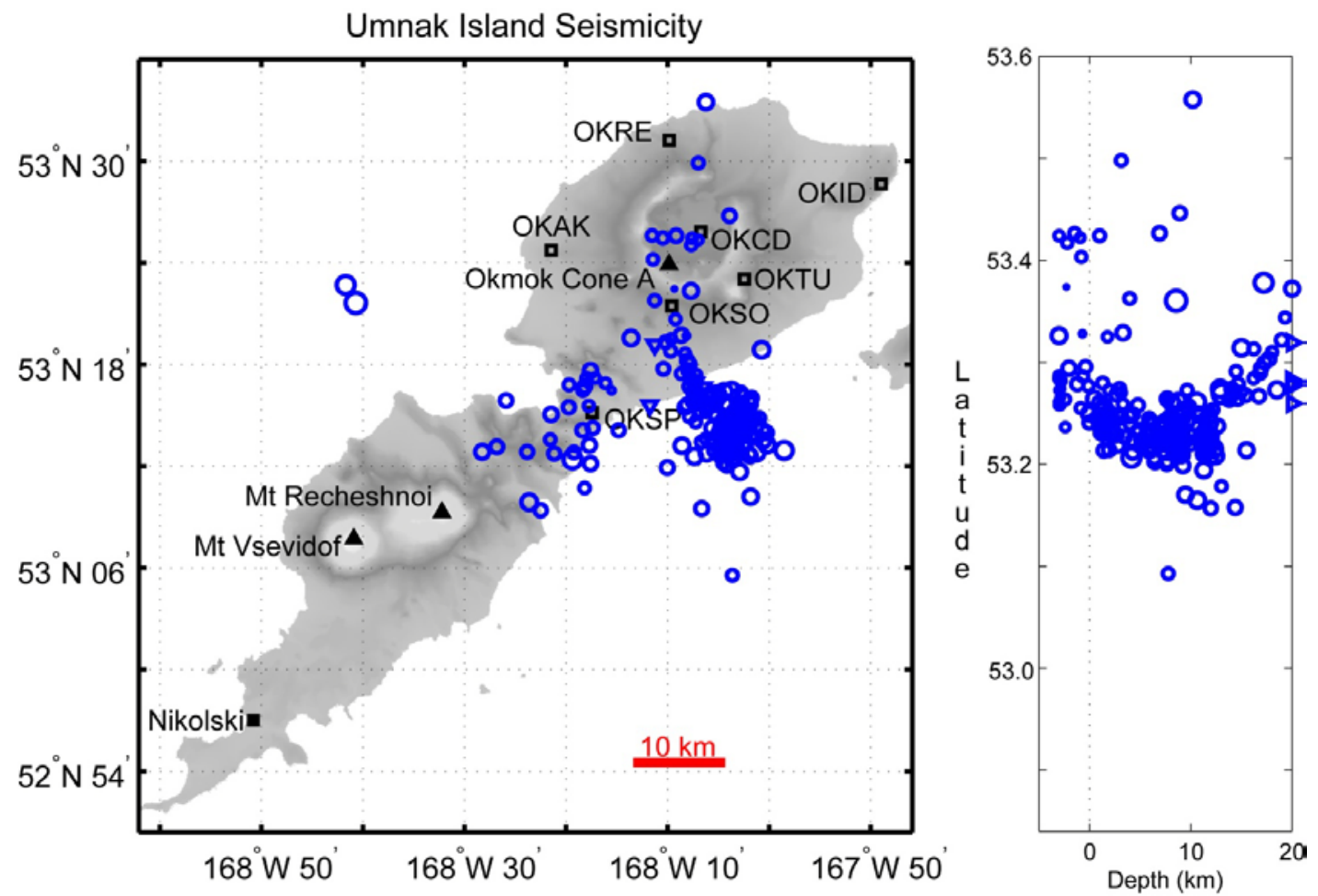

Mag. Symb. Size

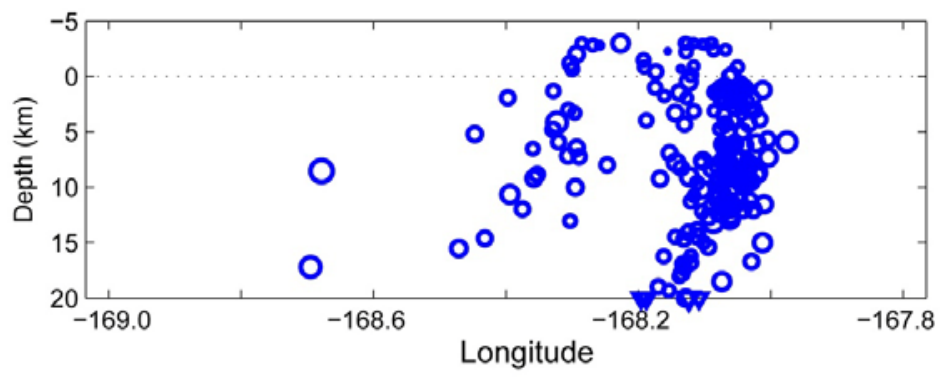

$\begin{array}{ll}0 & 0 \\ 1 & 0 \\ 2 & 0 \\ 3 & 0 \\ 4 & \bigcirc \\ 5 & \bigcirc\end{array}$

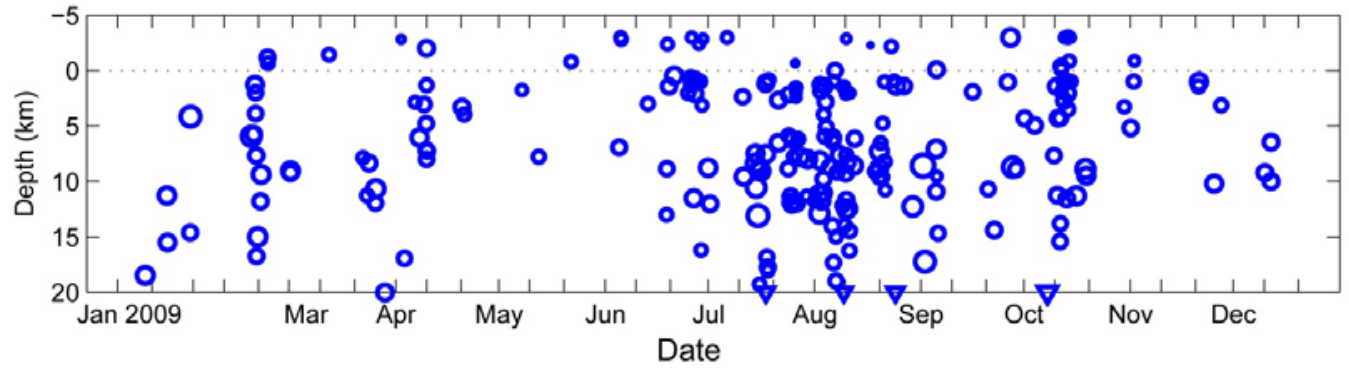

Figure A23. Summary plots of earthquakes located on Umnak Island in 2009. Open circles show hypocenter locations shallower than $20 \mathrm{~km}$ and open triangles indicate hypocenters with depths of $20 \mathrm{~km}$ and deeper. Hypocenter symbols are scaled with magnitude. Permanent seismograph stations are shown by open squares and labeled by station code. Solid triangles are used to show volcanic centers and solid squares are used to show other points of interest. Vertical exaggeration is $x 1.1$. See appendix B for station information. 

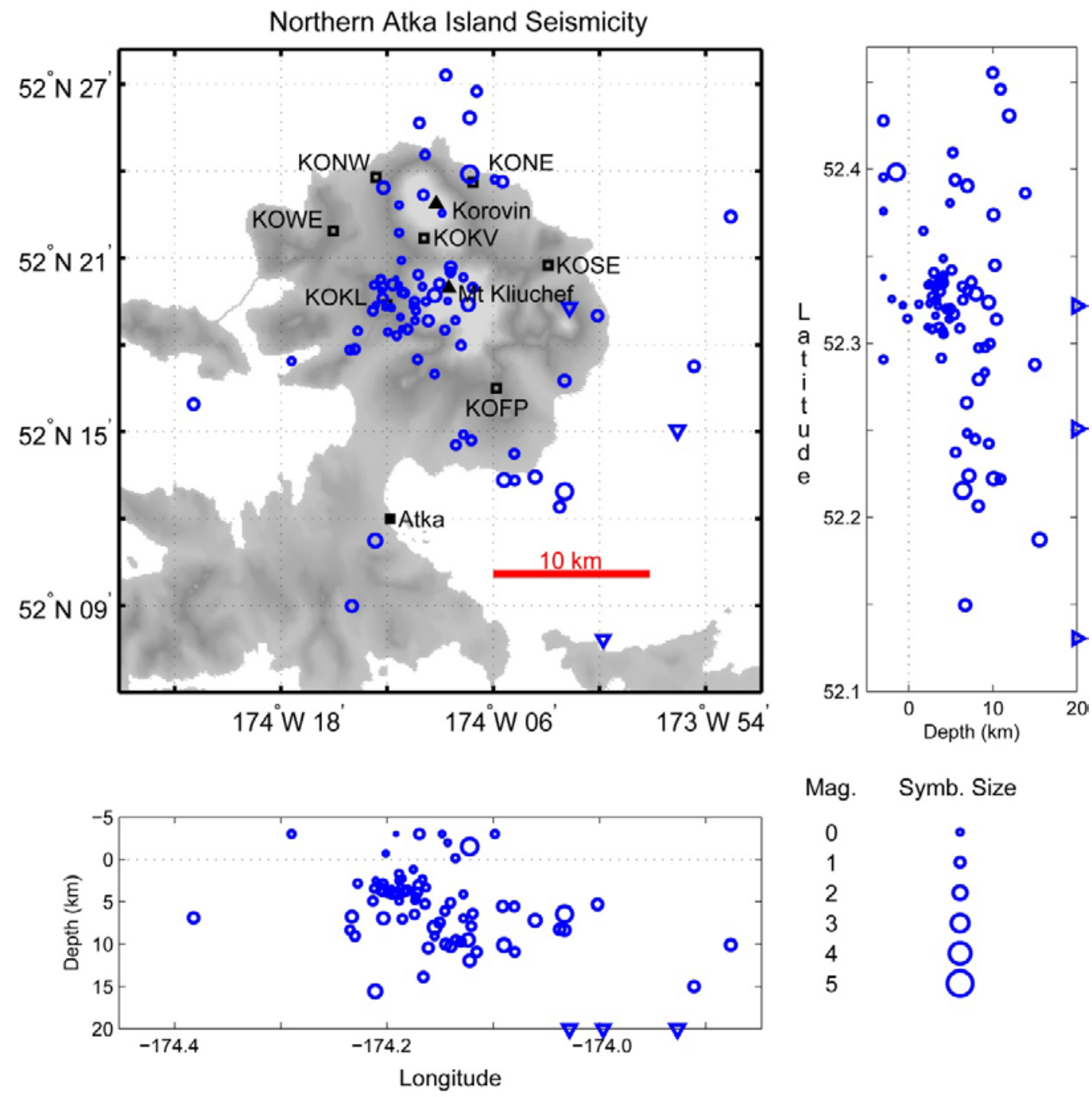

Mag. Symb. Size

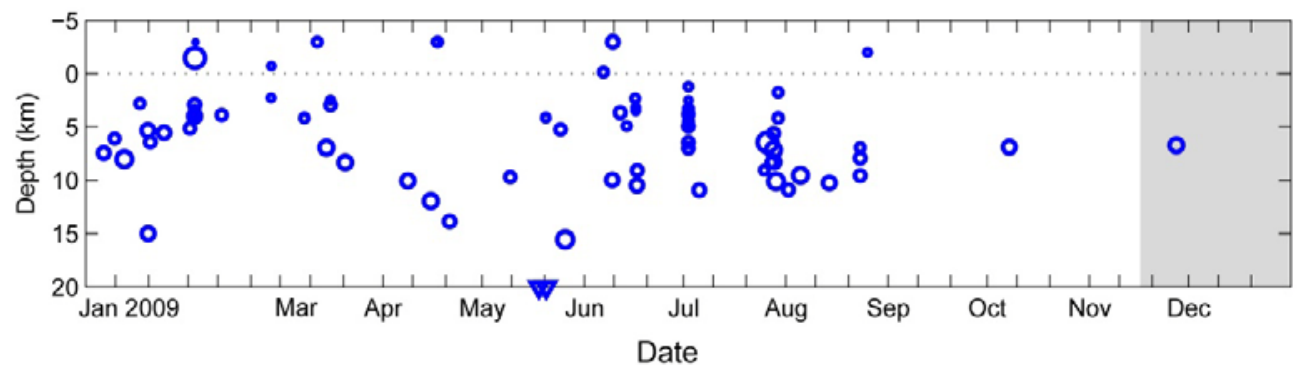

Figure A24. Summary plots of earthquakes located near Korovin Volcano and Mount Kliuchef in 2009. Open circles show hypocenter locations shallower than $20 \mathrm{~km}$ and open triangles indicate hypocenters with depths of $20 \mathrm{~km}$ and deeper. Hypocenter symbols are scaled with magnitude. Permanent seismograph stations are shown by open squares and labeled by station code. Solid triangles are used to show volcanic centers and solid squares are used to show other points of interest. The gray shaded area in time depth plot shows the time frame the subnetwork was not on the monitored volcano list. Vertical exaggeration is $x 055$. See appendix B for station information. 

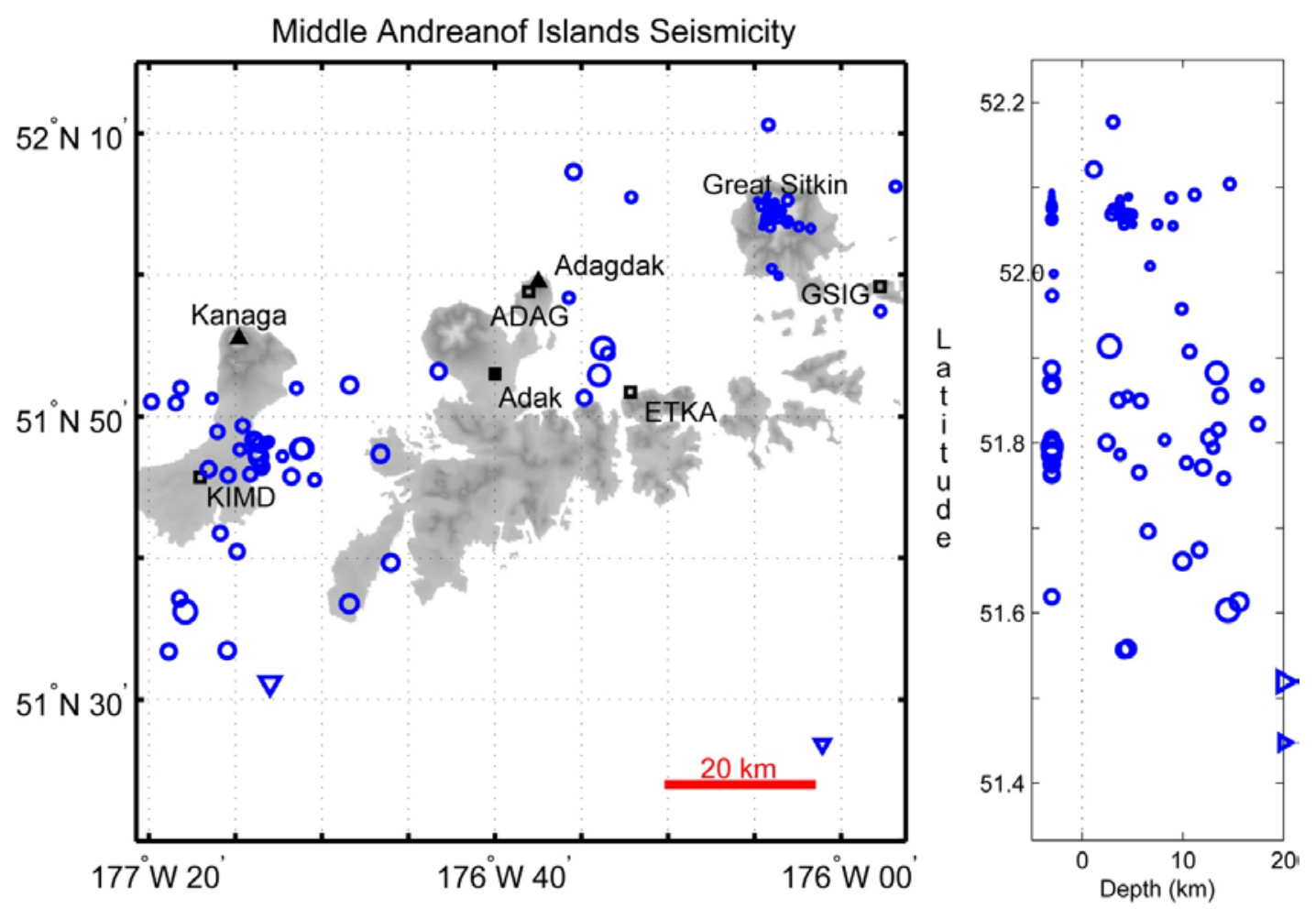

Mag. Symb. Size
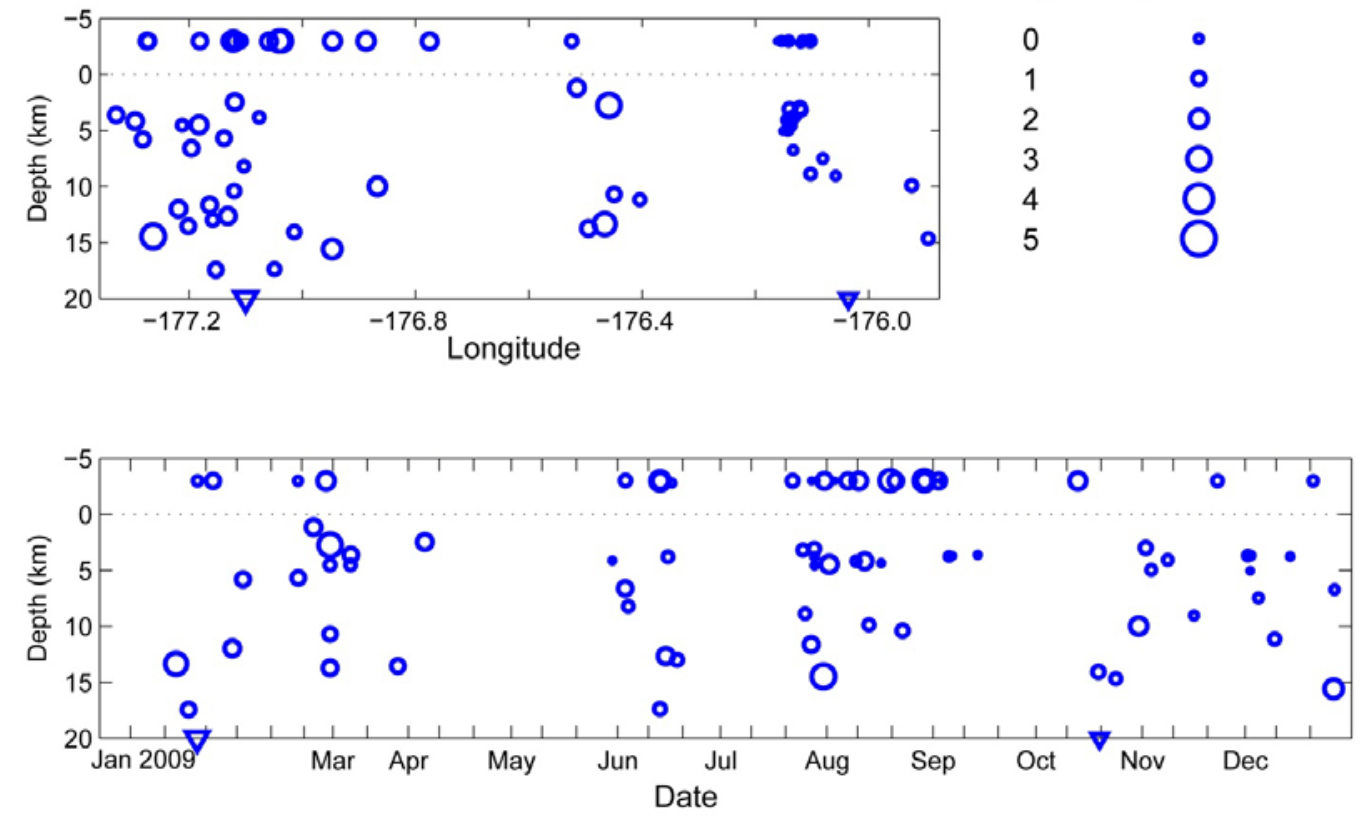

Figure A25. Summary plots of earthquakes located in the Middle Andreanof Islands in 2009. Open circles indicate hypocenters shallower than $20 \mathrm{~km}$ and open triangles indicate hypocenters with depths of $20 \mathrm{~km}$ and deeper. Hypocenter symbols are scaled with magnitude. Permanent seismograph stations are shown by open squares and labeled by station code. Solid triangles are used to show volcanic centers and solid squares are used to show other points of interest. Vertical exaggeration is $x 1.3$. See appendix B for station information. 

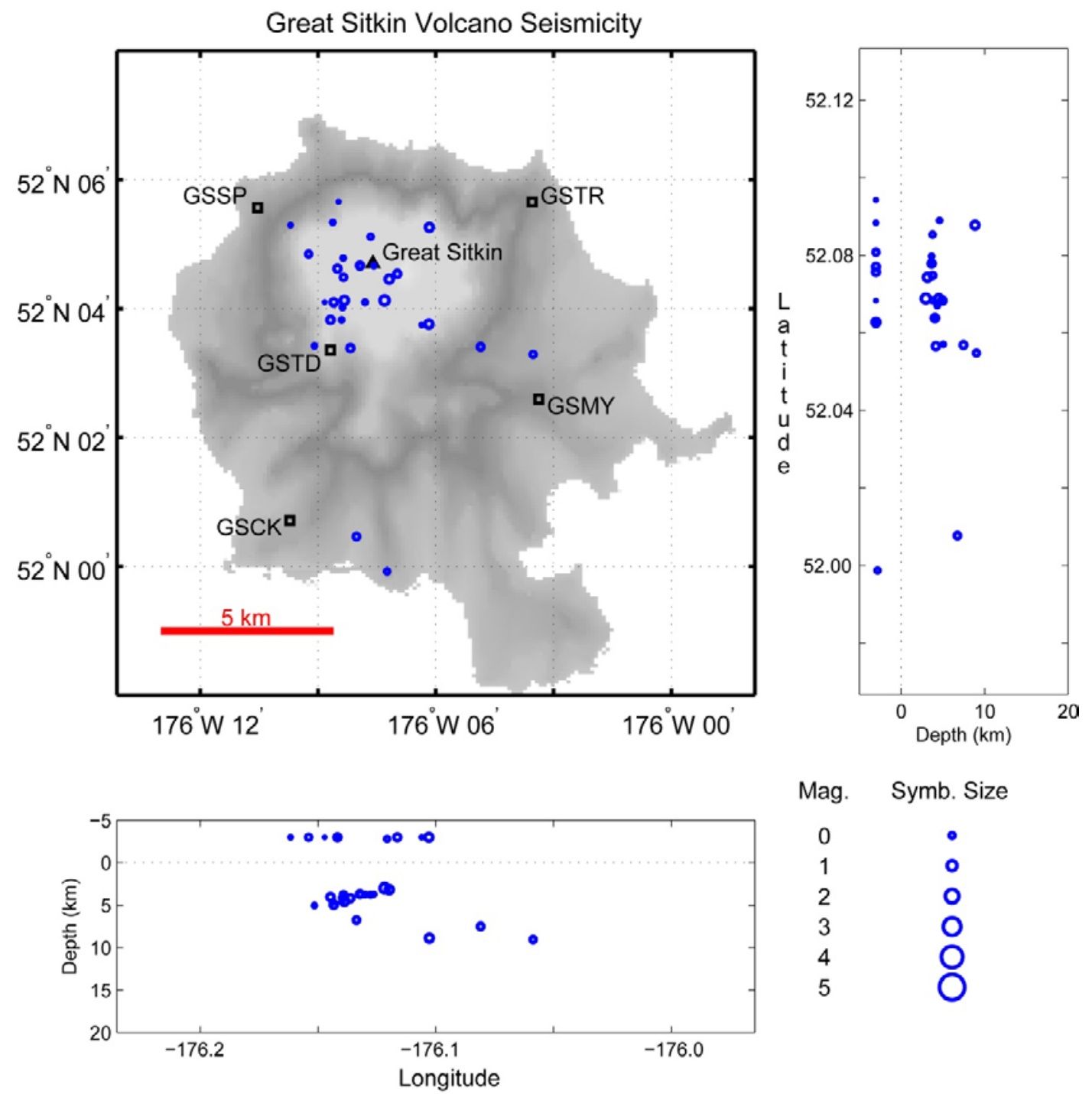

Mag. Symb. Size

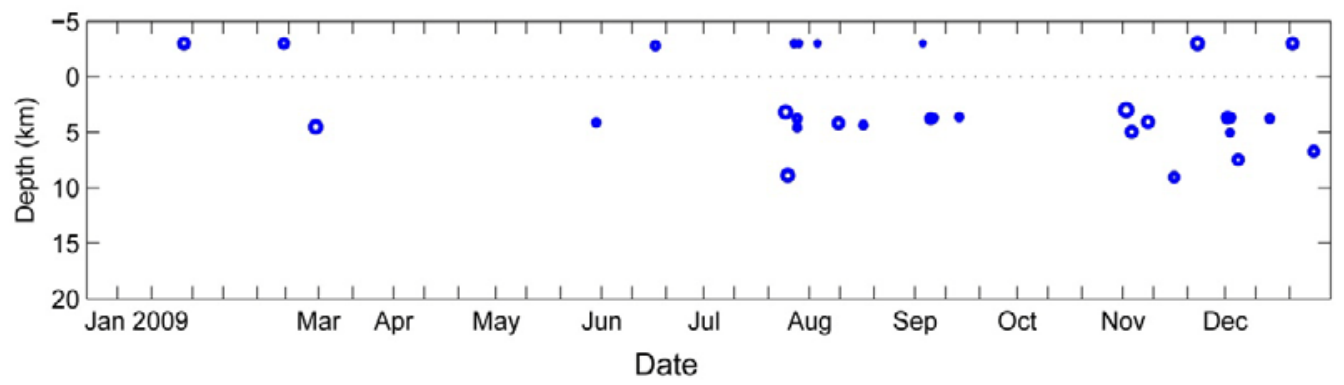

Figure A26. Summary plots of earthquakes located near Great Sitkin Volcano in 2009. Open circles indicate hypocenters shallower than $20 \mathrm{~km}$ and are scaled with magnitude. Permanent seismograph stations are shown by open squares and labeled by station code. Solid triangles are used to show volcanic centers. Vertical exaggeration is $x 0.25$. See appendix $B$ for station information. 

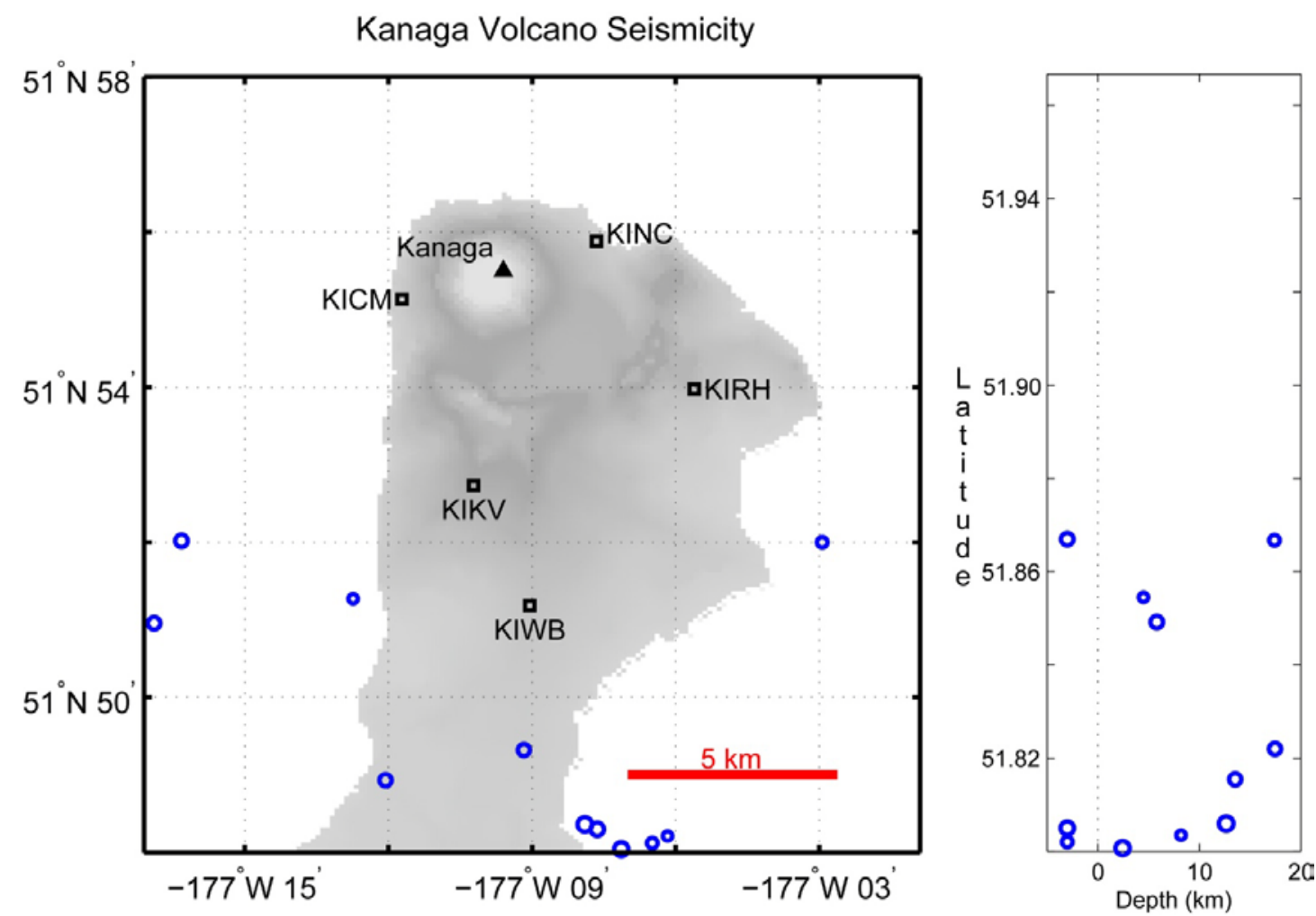

Mag. Symb. Size
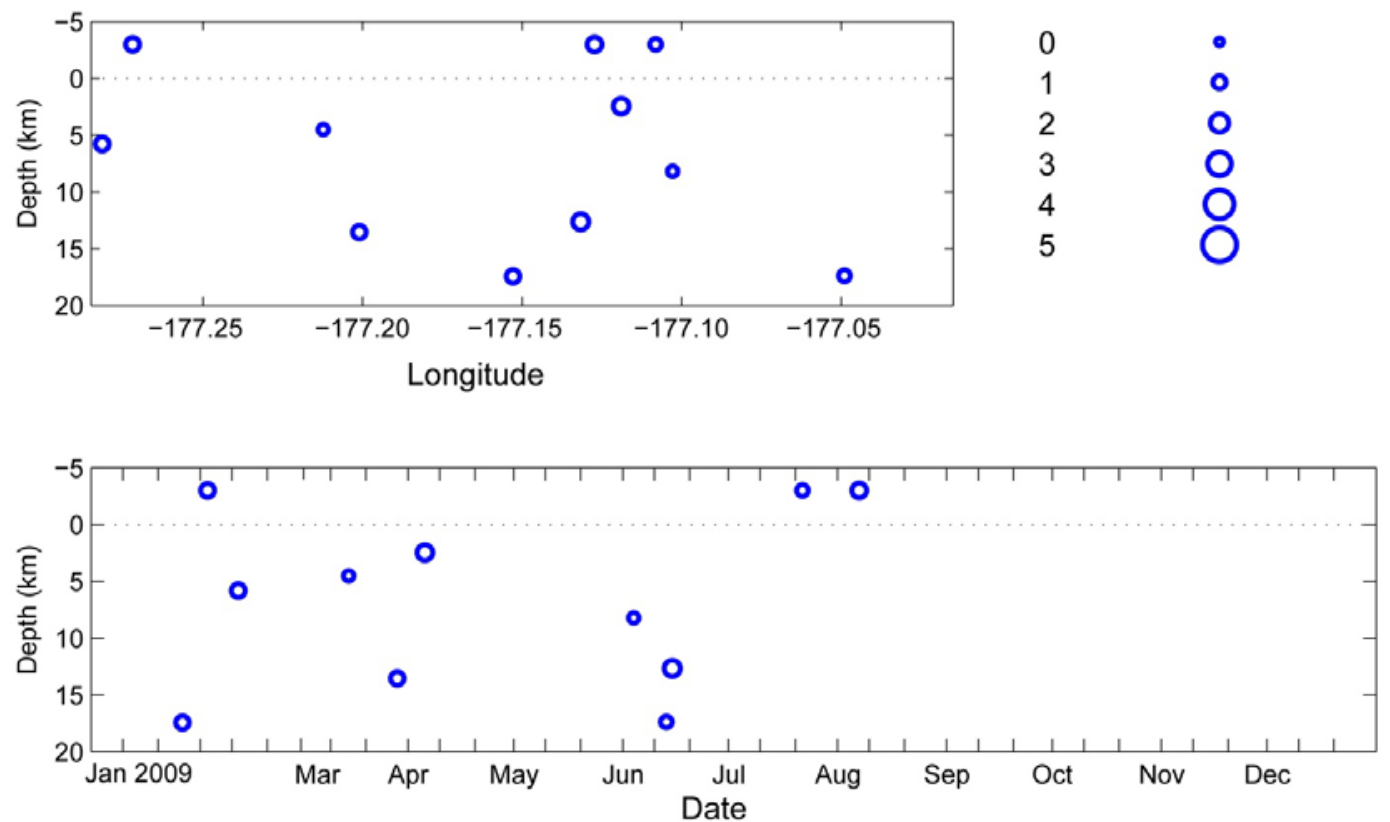

Figure A27. Summary plots of earthquakes located near Kanaga Volcano in 2009. Open circles indicate hypocenters shallower than $20 \mathrm{~km}$ and are scaled with magnitude. Permanent seismograph stations are shown by open squares and labeled by station code. Solid triangles are used to show volcanic centers. Vertical exaggeration is $x 0.25$. See appendix $B$ for station information. 

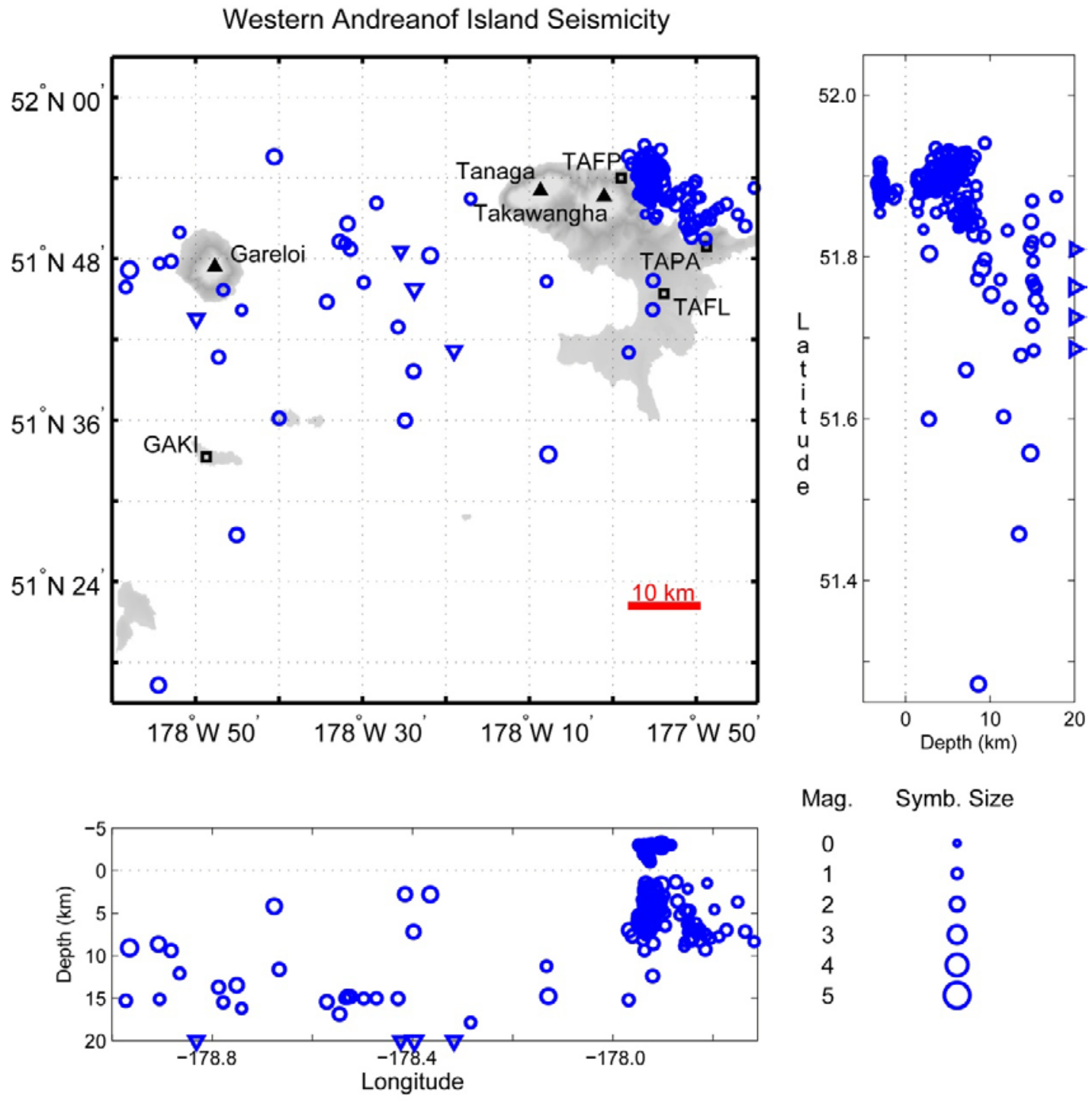

Mag. Symb. Size
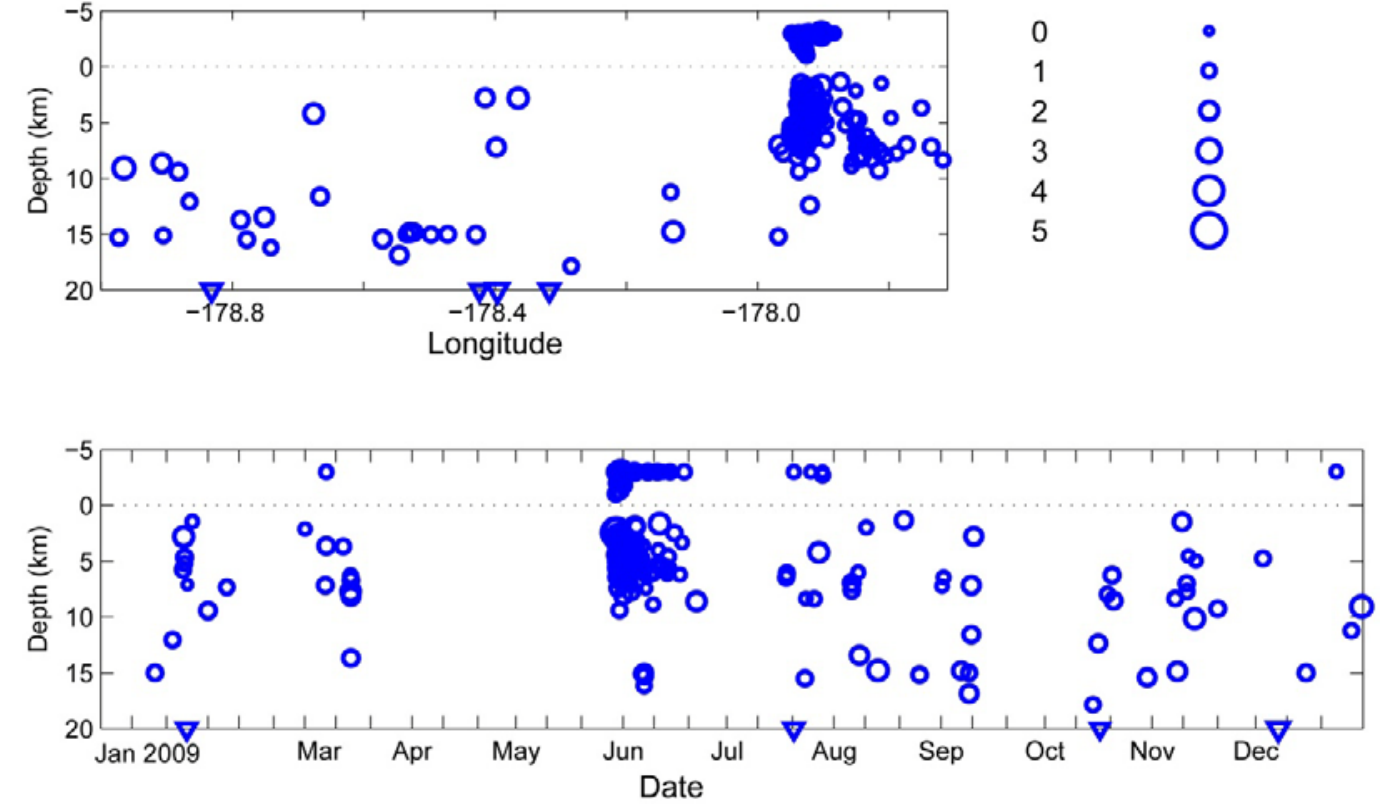

Figure A28. Summary plots of earthquakes located in the Western Andreanof Islands in 2009. Open circles indicates hypocenters shallower than $20 \mathrm{~km}$ and open triangles indicate hypocenters with depths of $20 \mathrm{~km}$ and deeper with symbols scaled by magnitude. Permanent seismograph stations are shown by open squares and labeled by station code. Solid triangles are used to show volcanic centers. Vertical exaggeration is $\mathrm{x} 0.4$. See appendix $B$ for station information. 

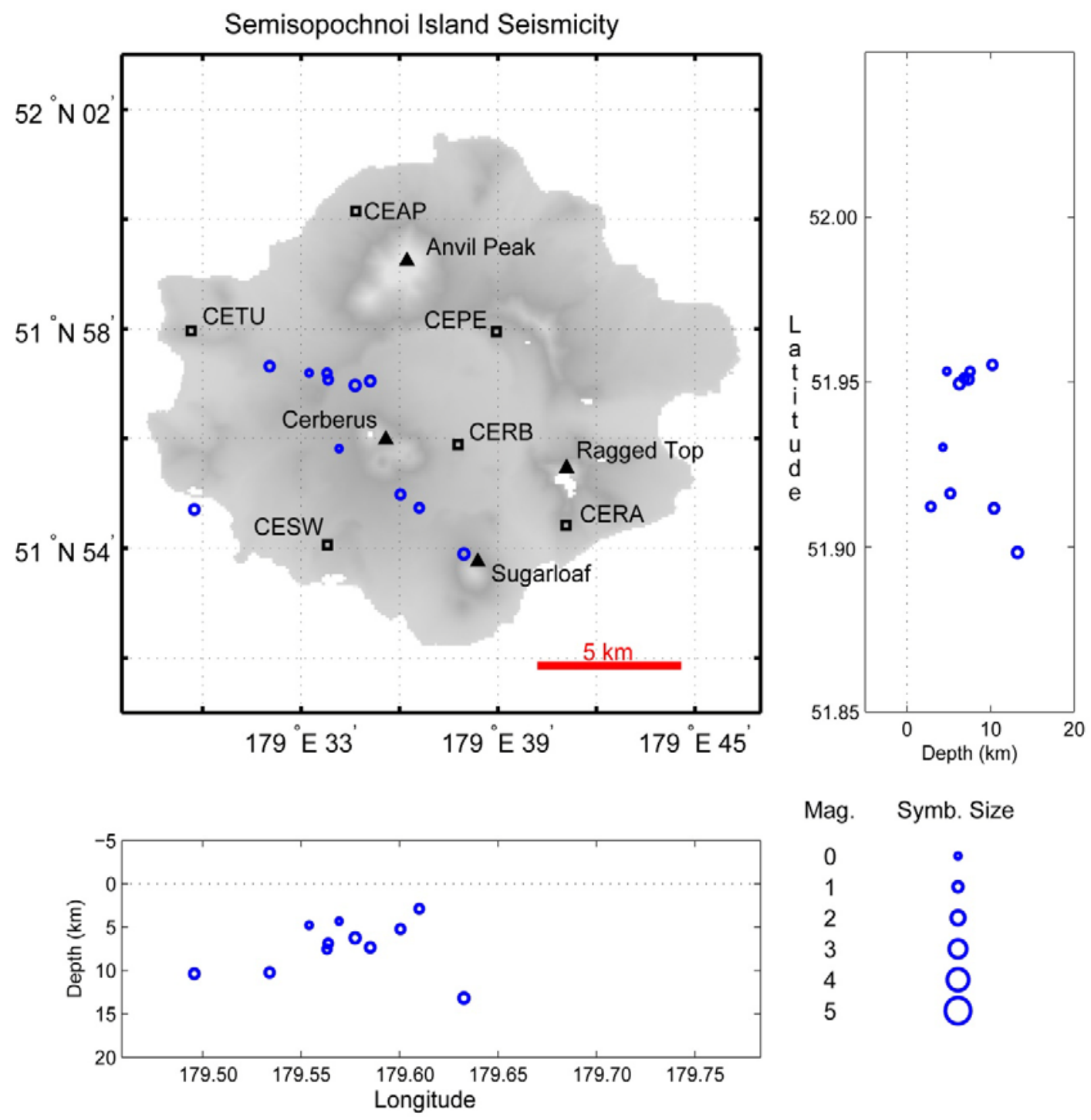

Mag. Symb. Size
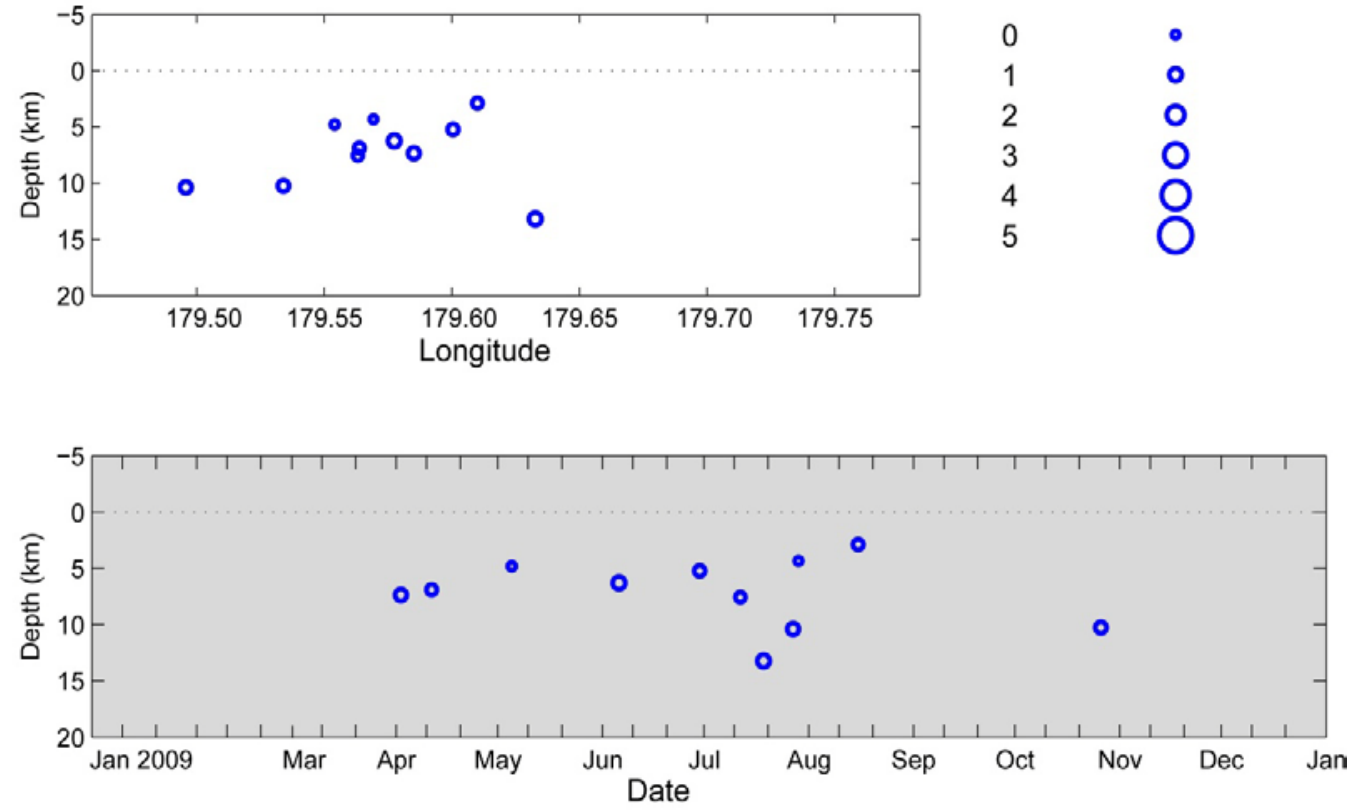

Figure A29. Summary plots of earthquakes located on Semisopochnoi Island in 2009. Open circles indicates hypocenters shallower than $20 \mathrm{~km}$ and are scaled with magnitude. Permanent seismograph stations are shown by open squares and labeled by station code. Solid triangles are used to show volcanic centers. The gray shaded area in time depth plot shows the time frame the subnetwork was not on the monitored volcano list. Vertical exaggeration is $\mathrm{x} 0.3$. See appendix $B$ for station information. 

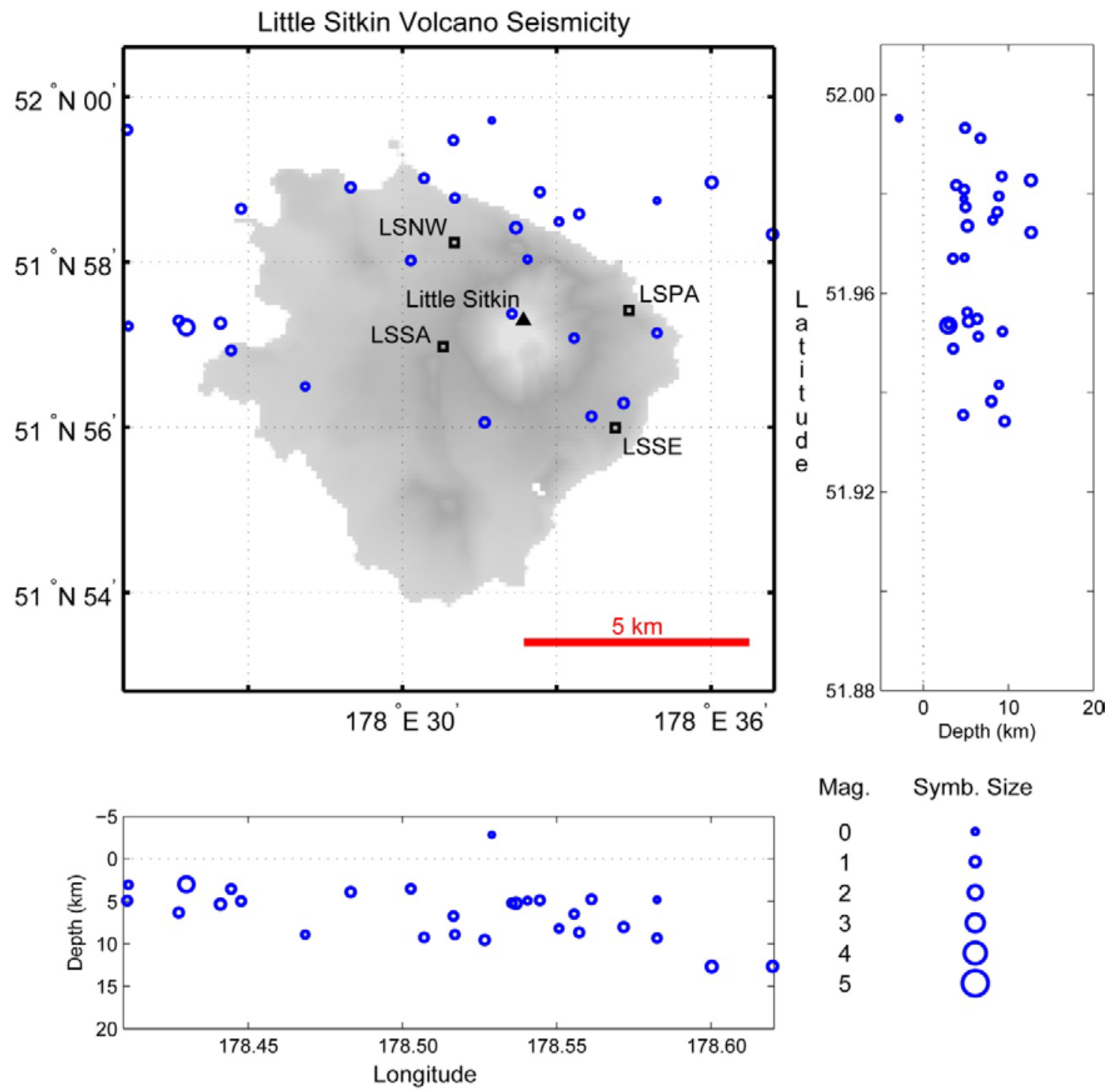

Mag. Symb. Size

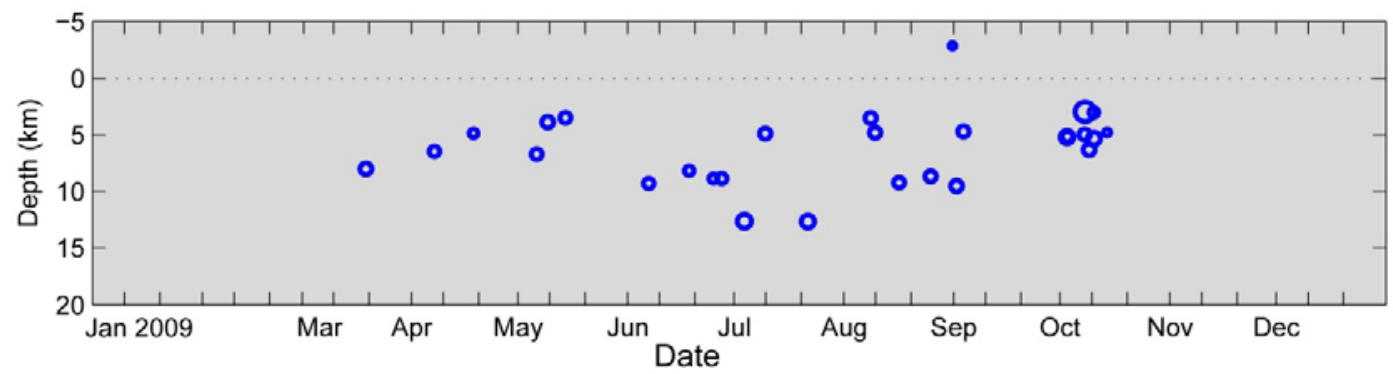

Figure A30. Summary plots of earthquakes located near Little Sitkin Volcano in 2009. Open circles indic ate hypocenters shallower than $20 \mathrm{~km}$ and are scaled with magnitude. Permanent seismograph stations are shown by open squares and labeled by station code. Solid triangles are used to show volcanic centers. The gray shaded area in time depth plot shows the time frame the subnetwork was not on the monitored volcano list. Vertical exaggeration is $\mathbf{x} 0.2$. See appendix B for station information. 


\section{Appendix B. Parameters for Alaska Volcano Observation Seismograph Stations (datum NAD27) in 2009.}

This list includes station parameters for seismograph stations operated by the Alaska Volcano Observatory (AVO), Alaska Earthquake Information Center (AEIC) and the West Coast-Alaska Tsunami Warning Center (WC-ATWC) that were used to locate earthquakes in the AVO catalog. The open date is the date that data were first recorded and the close date is the date that recording was stopped. Discounting temporary data outages, date is available for each listed station between the open and close date. Stations still in operation are indicated by a dash in the close date column.

\section{$\underline{\text { Station Latitude }(\mathrm{N})}$ Longitude $(\mathrm{E})$ Elevation $(\mathrm{m})$ Seismometer Open date $\underline{\text { Close date }}$}

\begin{tabular}{|c|c|c|c|c|c|c|}
\hline Akutan & Peak subn & (12 station & $6 \mathrm{co}$ & & & \\
\hline AHB & 5406.916 & -16548.943 & 447 & L4 & $1996 / 07 / 24$ & - \\
\hline $\mathrm{AKBB}^{3}$ & 5405.905 & -16555.907 & 310 & CMG-6TD & $2005 / 07 / 05$ & - \\
\hline $\mathrm{AKGG}^{3}$ & 5411.930 & -16559.495 & 326 & CMG-6TD & $2003 / 06 / 27$ & . \\
\hline $\mathrm{AKLV}^{3}$ & 5409.762 & -16557.336 & 551 & CMG-6TD & $2003 / 07 / 02$ & . \\
\hline $\mathrm{AKMO}^{3}$ & 5405.471 & -16600.634 & 277 & CMG-6TD & $2003 / 06 / 25$ & - \\
\hline $\mathrm{AKRB}^{3}$ & 5407.803 & -16604.125 & 334 & CMG-6TD & $2003 / 06 / 29$ & . \\
\hline $\mathrm{AKS}^{3}$ & 5406.624 & -16541.803 & 213 & L22 & $1996 / 07 / 24$ & . \\
\hline $\mathrm{AKT}^{3}$ & 5408.15 & -16546.2 & 12 & CMG-40T & $1996 / 03 / 18$ & . \\
\hline AKV & 5407.571 & -16557.763 & 863 & L4 & $1996 / 07 / 24$ & . \\
\hline HSB & 5411.205 & -16554.743 & 497 & L4 & $1996 / 07 / 24$ & . \\
\hline LVA & 5409.654 & -16602.025 & 457 & L4 & $1996 / 07 / 24$ & . \\
\hline ZRO & 5405.494 & -16558.678 & 446 & L4 & $1996 / 07 / 24$ & \\
\hline
\end{tabular}

Aniakchak Crater subnet ( 6 stations - 8 components)

\begin{tabular}{|c|c|c|c|c|}
\hline ANNE & 5654.763 & -158 03.534 & 705 & L4 \\
\hline ANNW & 5657.986 & -15812.895 & 816 & L4 \\
\hline ANON $^{3}$ & 5655.188 & -15810.293 & 445 & L22 \\
\hline ANPB & 5648.141 & -158 16.847 & 658 & L4 \\
\hline ANPK & 5650.499 & -158 07.572 & 972 & L4 \\
\hline AZAC & 5653.727 & -15813.841 & 1,057 & L4 \\
\hline
\end{tabular}

$1997 / 07 / 18$

$1997 / 07 / 18$

$2000 / 07 / 10$

$1997 / 07 / 18$

$1997 / 07 / 18$

$2003 / 07 / 12$

Augustine Volcano subnet (9 stations - 18 components)

$\begin{array}{lllll}\text { AU22 }^{3} & 5922.247 & -15321.301 & 105 & \text { SM } \\ \text { AUE*P }^{*} & 5922.308 & -15322.504 & 168 & \text { S13 } \\ \text { AUH } & 5921.833 & -15326.591 & 890 & \text { S13 } \\ \text { AUI }^{3} & 5920.11 & -15325.66 & 293 & \text { S13 } \\ \text { AUL }^{3} & 5922.937 & -15326.142 & 360 & \text { S13 } \\ \text { AUL }^{3} & 5922.937 & -15326.142 & 360 & \text { CMG-6TD } \\ \text { AUNW }^{*} & 5922.694 & -15328.609 & 160 & \text { L4 } \\ \text { AUP } & 5921.805 & -15325.210 & 1,033 & \text { S13 } \\ \text { AUSE } & 5920.481 & -15323.850 & 152 & \text { L4 } \\ \text { AUW } & 5922.205 & -15328.249 & 276 & \text { S13 }\end{array}$

$2007 / 09 / 01$

$1980 / 10 / 29$

$1978 / 12 / 01$

$1978 / 04 / 06$

$1980 / 10 / 29$

$1997 / 08 / 27$

$2007 / 03 / 15$

$1977 / 09 / 22$

$2006 / 02 / 03$

$1976 / 10 / 17$

Mount Cerberus Subnet (6 stations - 8 components)

$\begin{array}{lllll}\text { CEAP } & 5200.146 & 17934.667 & 244 & \text { L4 } \\ \text { CEPE } & 5157.949 & 17938.950 & 335 & \text { L4 } \\ \text { CERA } & 5154.419 & 17941.074 & 305 & \text { L4 } \\ \text { CERB }^{3} & 5155.886 & 17937.783 & 305 & \text { L4-3D } \\ \text { CESW } & 5154.060 & 17933.800 & 238 & \text { L4 } \\ \text { CETU } & 5157.965 & 17929.651 & 335 & \text { L4 }\end{array}$

$2005 / 09 / 17$

$2005 / 09 / 17$

$2005 / 09 / 26$

$2005 / 09 / 18$

$2005 / 09 / 18$

$2005 / 09 / 22$ 
44 Catalog of Earthquake Hypocenters at Alaskan Volcanoes: January 1 through December 31, 2009

Station Latitude (N) Longitude (E) Elevation $(\mathrm{m})$ Seismometer Open date $\underline{\text { Close date }}$

Mount Dutton subnet (5 stations - 5 components)

$\begin{array}{lllllll}\text { BLDY } & 5511.670 & -16247.018 & 259 & \text { L4 } & 1996 / 07 / 11 & - \\ \text { DOL } & 5508.976 & -16151.702 & 439 & \text { L4 } & 1996 / 07 / 11 & - \\ \text { DRR3 } & 5458.014 & -16215.665 & 457 & \text { L4 } & 1996 / 07 / 11 & - \\ \text { DT1 } & 5506.427 & -16216.859 & 198 & \text { L4 } & 1991 / 06 / 21 & - \\ \text { DTN } & 5508.744 & -16215.419 & 396 & \text { S13 } & 1988 / 07 / 16 & -\end{array}$

Fourpeaked subnet (4 stations - 7 components)

$\begin{array}{lllllll}\text { CDD } & 5855.771 & -15338.558 & 622 & \text { S13 } & 1981 / 08 / 17 & - \\ \text { FONW }^{* P} & 5850.086 & -15355.102 & 905 & \text { L-4 } & 2006 / 10 / 19 & - \\ \text { FOPK }^{*} & 5845.480 & -15328.433 & 546 & \text { L4 } & 2006 / 09 / 25 & \text { - } \\ \text { FOSS }^{* P} & 5847.965 & -15341.699 & 1268 & \text { L-4 } & 2006 / 10 / 10\end{array}$

Gareloi Volcano subnet ( 6 stations - 8 components)

GAEA $5146.980-17844.810 \quad 326 \quad$ L

GAKI $5133.267-17848.725 \quad 99 \quad$ L4

GALA $5145.704 \quad-17846.292 \quad 315 \quad$ L4

$4 \quad 2003 / 08 / 30$

$2003 / 09 / 01$

$2003 / 08 / 30$

$2003 / 09 / 02$

GANE $\quad 5149.135-17846.603 \quad 322$

L4

GANO $5149.220-17848.230 \quad 451$

L4

$\begin{array}{lllll}\text { GASW }^{3} & 5146.731 & -17851.276 & 248 & \text { L22 }\end{array}$

$2003 / 09 / 02$

$2003 / 08 / 30$

Great Sitkin Volcano subnet (6 stations - 8 components)

$\begin{array}{llllll}\text { GSCK } & 5200.712 & -17609.718 & 384 & \text { L4 } & 1999 / 09 / 15 \\ \text { GSIG } & 5159.181 & -17555.502 & 407 & \text { L4 } & 1999 / 09 / 03 \\ \text { GSMY } & 5202.594 & -17603.376 & 418 & \text { L4 } & 1999 / 09 / 03 \\ \text { GSSP } & 5205.566 & -17610.541 & 295 & \text { L4 } & 1999 / 09 / 15 \\ \text { GSTD }^{3} & 5203.356 & -17608.685 & 873 & \text { L22 } & 1999 / 09 / 03 \\ \text { GSTR } & 5205.655 & -17603.546 & 536 & \text { L4 } & 1999 / 09 / 03\end{array}$

\begin{tabular}{|c|c|c|c|c|c|c|}
\hline \multicolumn{7}{|c|}{ Iliamna Volcano subnet (6 stations - 8 components) } \\
\hline ILI & 6004.877 & -15257.502 & 771 & L4 & $1987 / 09 / 15$ & - \\
\hline ILS & 5957.454 & -15304.083 & 1,125 & $\mathrm{~S} 13$ & $1996 / 08 / 28$ & - \\
\hline ILW & 6003.585 & -15308.222 & 1,646 & $\mathrm{~S} 13$ & $1994 / 09 / 09$ & - \\
\hline INE & 6003.630 & -15303.732 & 1,634 & $\mathrm{~S} 13$ & $1990 / 08 / 29$ & - \\
\hline $\mathrm{IVE}^{3}$ & 6001.014 & -15300.981 & 1,173 & S13,L22 & $1996 / 09 / 19$ & - \\
\hline IVS & 6000.55 & -15304.85 & 2,332 & S13 & $1990 / 08 / 29$ & - \\
\hline
\end{tabular}

Kanaga Volcano subnet ( 6 stations - 6 components)

$\begin{array}{lllllll}\text { KICM } & 5155.136 & -17711.718 & 183 & \text { L4 } & 1999 / 09 / 15 & - \\ \text { KIKV } & 5152.730 & -17710.223 & 411 & \text { L4 } & 1999 / 09 / 15 & - \\ \text { KIMD } & 5145.697 & -17714.093 & 183 & \text { L4 } & 1999 / 09 / 15 & - \\ \text { KINC } & 5155.884 & -17707.657 & 198 & \text { L4 } & 1999 / 09 / 15 & - \\ \text { KIRH } & 5153.976 & -17705.611 & 309 & \text { L4 } & 1999 / 09 / 03 & - \\ \text { KIWB } & 5151.183 & -17709.049 & 244 & \text { L4 } & 1999 / 09 / 03\end{array}$


$\underline{\text { Station Latitude }(\mathrm{N})}$ Longitude $(\mathrm{E})$ Elevation $(\mathrm{m})$ Seismometer $\underline{\text { Open date }}$ Close date

\begin{tabular}{|c|c|c|c|c|c|c|}
\hline \multicolumn{7}{|c|}{ Katmai Volcanic Cluster subnet (20 stations - 30 components) } \\
\hline $\mathrm{ACH}^{3}$ & 5812.64 & -15519.56 & 960 & L22 & $1996 / 07 / 25$ & - \\
\hline ANCK & 5811.93 & -15529.64 & 869 & L4 & $1996 / 07 / 25$ & - \\
\hline CAHL & 5803.15 & -15518.09 & 807 & L4 & $1996 / 07 / 25$ & - \\
\hline CNTC & 5815.87 & -15553.02 & 1,158 & L4 & $1996 / 07 / 25$ & - \\
\hline $\mathrm{KA} 01^{\#}$ & 5818.858 & -15505.870 & 810 & CMT-6TD & $2008 / 07 / 20$ & - \\
\hline $\mathrm{KAO2}^{\#}$ & 5815.116 & -15509.119 & 999 & CMT3-ESP & $2008 / 07 / 20$ & - \\
\hline $\mathrm{KAO3}^{\#}$ & 5815.611 & -15507.881 & 1,015 & CMT-6TD & $2008 / 07 / 20$ & - \\
\hline $\mathrm{KAO4}^{\#}$ & 5813.354 & -15508.650 & 994 & CMT-6TD & $2008 / 07 / 20$ & - \\
\hline KA05 & 5812.942 & -15505.083 & 935 & CMT-6TD & $2008 / 07 / 20$ & - \\
\hline KA06 & 5812.660 & -15501.144 & 1, 003 & CMT-6TD & $2008 / 07 / 20$ & - \\
\hline $\mathrm{KA} 11^{\#}$ & 5817.006 & -15508.357 & 1,098 & CMT-6TD & $2008 / 07 / 20$ & - \\
\hline $\mathrm{KA} 12^{\#}$ & 5813.904 & -15516.001 & 884 & CMT-6TD & $2008 / 07 / 20$ & - \\
\hline $\mathrm{KA} 13^{\#}$ & 5813.262 & -15511.507 & 899 & CMT3-ESP & $2008 / 07 / 20$ & - \\
\hline $\mathrm{KA} 15^{\#}$ & 5811.573 & -15511.143 & 926 & CMT-6TD & $2008 / 07 / 20$ & - \\
\hline $\mathrm{KA} 16^{\#}$ & 5810.800 & -15505.999 & 714 & CMT-6TD & $2008 / 07 / 20$ & - \\
\hline KABR & 5807.87 & -15458.15 & 884 & L4 & $1998 / 08 / 12$ & - \\
\hline$K A B U^{3}$ & 5816.225 & -15516.934 & 1,065 & CMT-6TD & 2004/08/01 & - \\
\hline KAHC & 5838.94 & -15500.36 & 1,250 & L4 & $1998 / 10 / 12$ & - \\
\hline KAHG & 5829.64 & -15432.78 & 923 & L4 & 1998/10/12 & - \\
\hline KAIC & 5829.10 & -15502.75 & 734 & L4 & $1998 / 10 / 12$ & - \\
\hline $\mathrm{KAKN}^{3}$ & 5817.819 & -15503.668 & 1,049 & CMG-6TD & $2004 / 08 / 01$ & - \\
\hline $\mathrm{KAPH}^{3}$ & 5835.81 & -15420.81 & 907 & L22 & $1998 / 10 / 12$ & - \\
\hline KARR & 5829.87 & -15442.20 & 610 & L4 & $1998 / 10 / 12$ & - \\
\hline KAWH & 5823.02 & -15447.95 & 777 & L4 & $1998 / 10 / 12$ & - \\
\hline KBM & 5816.50 & -15512.10 & 732 & L4 & $1991 / 07 / 22$ & - \\
\hline $\mathrm{KCE}$ & 5814.60 & -15511.00 & 777 & L4 & $1991 / 07 / 22$ & - \\
\hline $\mathrm{KCG}^{3}$ & 5818.457 & -15506.684 & 762 & L22 & $1988 / 08 / 01$ & - \\
\hline KEL & 5826.401 & -15544.442 & 975 & L4 & $1988 / 08 / 01$ & - \\
\hline KJL & 5803.24 & -15534.39 & 792 & L4 & $1996 / 07 / 25$ & - \\
\hline KVT & 5822.90 & -15517.70 & 457 & L4 & 1988/08/01 & - \\
\hline MGLS & 5808.06 & -15509.65 & 472 & L4 & $1996 / 07 / 25$ & - \\
\hline \multicolumn{7}{|c|}{ Korovin Volcano subnet (7 stations - 9 components) } \\
\hline KOFP & 5216.508 & -17405.832 & 662 & L4 & $2004 / 07 / 02$ & - \\
\hline KOKL & 5219.393 & -17412.012 & 758 & L4 & 2004/07/05 & - \\
\hline $\mathrm{KOKV}^{3}$ & 5221.685 & -17409.915 & 776 & L22 & $2004 / 07 / 05$ & - \\
\hline KONE & 5223.611 & -17407.156 & 253 & L4 & $2004 / 07 / 10$ & - \\
\hline KONW & 5223.790 & -17412.629 & 334 & L4 & 2004/07/04 & - \\
\hline KOSE & 5220.749 & -17402.909 & 625 & L4 & 2004/07/07 & - \\
\hline KOWE & 5221.940 & -17415.040 & 527 & L4 & $2004 / 07 / 06$ & - \\
\hline \multicolumn{7}{|c|}{ Little Sitkin subnet (4 stations - 6 components) } \\
\hline LSNW & 5158.232 & 17831.011 & 290 & L4 & $2005 / 09 / 30$ & - \\
\hline $\operatorname{LSPA}^{3}$ & 5157.413 & 17834.405 & 335 & L4-3D & $2005 / 09 / 30$ & - \\
\hline LSSA & 5156.973 & 17830.793 & 549 & L4 & $2005 / 09 / 28$ & - \\
\hline LSSE & 5155.993 & 17834.139 & 335 & L4 & $2005 / 09 / 27$ & - \\
\hline
\end{tabular}


Station Latitude (N) Longitude (E) Elevation (m) Seismometer

Open date Close date

\begin{tabular}{lrrrr}
\multicolumn{5}{c}{ Makushin Volcano subnet (7 stations - 9 components) } \\
MCIR & 5357.086 & -16653.529 & 800 & L4 \\
MGOD & 5347.683 & -16652.561 & 650 & L4 \\
MNAT & 5353.028 & -16641.016 & 397 & L4 \\
MREP & 5348.629 & -16644.736 & 785 & L4 \\
MSOM & 5348.978 & -16656.187 & 146 & L4 \\
MSW $^{3}$ & 5354.929 & -16647.186 & 418 & L2 \\
MTBL $^{5} 5358.136$ & -16640.760 & 810 & L4
\end{tabular}

L4 1996/07/25

$4 \quad 1996 / 07 / 25$

$1996 / 07 / 25$

$2002 / 01 / 01$

$1996 / 07 / 25$

$1996 / 07 / 25$

$1996 / 07 / 25$

Okmok Caldera subnet (12 stations - 18 components)

OKAK $5324.740 \quad-16821.465 \quad 165$

OKCE $^{3} 5325.622-16809.858 \quad 515$

OKCF $\quad 5323.749 \quad-16808.175 \quad 685$

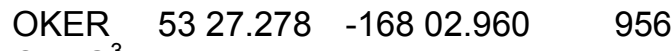

L4

$\begin{array}{llll}\mathrm{OKFG}^{3} & 5324.702 & -16754.568 & 201\end{array}$

OKID $\quad 5328.645 \quad-16748.972 \quad 437$

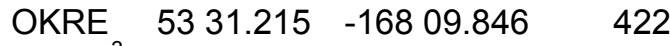

$\begin{array}{lllll}\text { OKSO }^{3} & 5321.447 & -168 & 09.591 & 460\end{array}$

OKSP $\quad 5315.156 \quad-168 \begin{array}{lll}17.431 & 608\end{array}$

OKTU $5323.035 \quad-16802.466 \quad 646$

OKWE $5328.328 \quad-16814.388 \quad 445$

OKWR $5326.084 \quad-16812.333$

1,017

L4 2005/07/11

CMG-6TD 2003/01/09

L4 2003/01/09

L4 2003/01/09

CMG-6TD 2003/01/09

L4 2003/01/09

L4 2003/01/09

CMG-6TD 2004/09/01

L4

$2003 / 01 / 09$

$2003 / 01 / 09$

$2003 / 01 / 09$

$2003 / 01 / 09$

Pavlof Volcano subnet (7 stations - 9 components)

BLHA $\quad 5542.276 \quad-16203.540 \quad 411$

HAG $\quad 5519.068-16154.144 \quad 516$

L4

L4

PN7A $^{P} \quad 5526.020-16159.713$

PS1A $5525.254-16144.496 \quad 283$

PS4A $5520.808 \quad-16151.276 \quad 322$

$\begin{array}{llll}\text { PV6 }^{3} & 5527.217 & -16155.112 & 747\end{array}$

PVV $\quad 5522.440 \quad-16147.396 \quad 173$

L4

L4

L4

L4

L4

L22

L4

$1996 / 07 / 11$

$1996 / 07 / 11$

$1996 / 07 / 11$

$1996 / 07 / 11$

$1996 / 07 / 11$

$1996 / 07 / 11$

1996/07/11

Mount Peulik subnet (7 stations - 9 components)

$\begin{array}{lcccl}\text { PLBL } & 5741.990 & -15649.131 & 461 & \text { L4 } \\ \text { PLK1 } & 5748.114 & -15636.433 & 78 & \text { L4 } \\ \text { PLK2 } & 5745.852 & -15619.458 & 401 & \text { L4 } \\ \text { PLK3 }^{3} & 5741.320 & -15616.044 & 494 & \text { L22 } \\ \text { PLK4 } & 5737.928 & -15621.464 & 1,031 & \text { L4 } \\ \text { PLK5 } & 5759.864 & -15652.662 & 49 & \text { L4 } \\ \text { PLWL } & 5802.696 & -15620.479 & 585 & \text { L4 }\end{array}$

$2004 / 08 / 01$

2004/08/01

$2004 / 08 / 01$

$2004 / 08 / 01$

$2004 / 08 / 01$

$2004 / 08 / 01$

$2004 / 08 / 01$ 
Station Latitude (N) Longitude (E) Elevation (m) Seismometer

$\begin{array}{lllcl}\text { Redoubt Volcano subnet (10 stations - 19 components) } \\ \text { DFR } & 6035.514 & -15241.160 & 1,090 & \text { L4 } \\ \text { NCT } & 6033.789 & -15255.568 & 1,079 & \text { L4 } \\ \text { RDDR } & 6035.093 & -15235.181 & 905 & \text { L4 } \\ \text { RDE }^{R} & 6035.252 & -15235.418 & 371 & \text { L4 } \\ \text { RDJH }^{3} & 6035.461 & -15248.213 & 1,414 & \text { CMG-6TD } \\ \text { RDN } & 6031.377 & -15244.273 & 1,400 & \text { L4 } \\ \text { RDT } & 6034.394 & -15224.315 & 930 & \text { L4 } \\ \text { RDWB }^{3} & 6029.284 & -15250.415 & 1,546 & \text { CMG-6TD } \\ \text { RED }^{3} & 6025.192 & -15246.308 & 1,064 & \text { L4 } \\ \text { REF }^{3 *} & 6029.362 & -15241.500 & 1,801 & \text { L22 } \\ \text { RSO }^{6} & 6027.73 & -15245.23 & 1,921 & \text { L4 }\end{array}$

Shishaldin Volcano subnet (7 stations - 11 components)

$\begin{array}{lllll}\text { BRPK } & 5438.730 & -16344.449 & 393 & \text { L4 } \\ \text { ISLZ } & 5443.559 & -16342.663 & 466 & \text { L4 } \\ \text { ISNN }^{3} & 5449.937 & -16346.706 & 466 & \text { L4 } \\ \text { SSBA }^{3} & 5446.363 & -16407.470 & 766 & \text { CMG-6TD } \\ \text { SSLN }^{P} & 5448.709 & -16359.756 & 637 & \text { L4 } \\ \text { SSLS }^{3} & 5442.718 & -16359.926 & 817 & \text { L22 } \\ \text { SSLW } & 5446.307 & -16407.282 & 636 & \text { L4 }\end{array}$

\section{Mount Spurr subnet (15 stations - 23 components)}

BGL $\quad 6116.012 \quad-15223.340 \quad 1,127$

$6104.21 \quad-15215.76 \quad 1,009$

$\begin{array}{llll}\text { CGL } & 6118.46 & -15200.40 & 1,082\end{array}$

CKL $\quad 6111.782-15220.268 \quad 1,281$

CKN $\quad 6113.44 \quad-15210.89 \quad 735$

CKT $\quad 6112.05 \quad-15212.37 \quad 975$

CP2 $\quad 6115.85 \quad-15214.51 \quad 1,981$

$\begin{array}{llll}\mathrm{CRP}^{3} & 6116.02 & -15209.33 & 1,622\end{array}$

NCG $\quad 6124.22 \quad-15209.40 \quad 1,244$

SPBG $^{3} \quad 6115.583-15222.194 \quad 1,087$

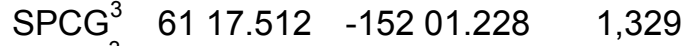

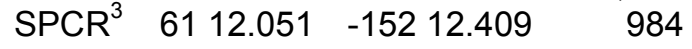

SPNW $\quad 6120.826 \quad-15236.236 \quad 1,040$

SPU $\quad 6110.90 \quad-15203.26 \quad 800$

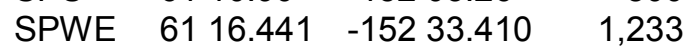

Open date Close date

$\begin{array}{cc}1988 / 08 / 15 & - \\ 1988 / 08 / 14 & - \\ 2009 / 07 / 01 & - \\ 2009 / 02 / 04 & 2009 / 07 / 01 \\ 2009 / 02 / 04 & - \\ 1988 / 08 / 13 & - \\ 1971 / 08 / 09 & - \\ 2009 / 02 / 04 & - \\ 1974 / 00 / 00 & - \\ 1992 / 07 / 27 & - \\ 1990 / 03 / 01 & -\end{array}$

$1997 / 07 / 27$

$2008 / 08 / 17$

$1997 / 07 / 27$

$2008 / 08 / 01$

$1997 / 07 / 27$

$1997 / 07 / 27$

$1997 / 07 / 27$

$1989 / 08 / 13$

$1991 / 07 / 01$

$1981 / 09 / 22$

$1989 / 08 / 05$

$1991 / 08 / 19$

$1992 / 09 / 16$

$1992 / 10 / 23$

$1981 / 08 / 26$

$1989 / 08 / 06$

$2004 / 09 / 09$

$2004 / 09 / 08$

$2004 / 09 / 08$

$2004 / 08 / 17$

$1971 / 08 / 10$

$2004 / 08 / 18$

$2003 / 08 / 28$

$2003 / 08 / 28$

$2003 / 08 / 27$

$2003 / 08 / 24$

$2003 / 08 / 27$

$2003 / 08 / 24$

Tanaga Volcano subnet ( 6 stations - 8 components)

$\begin{array}{llllll}\text { TACS } & 5151.792 & -17808.363 & 918 & \text { L4 } & 2003 / 08 / 28 \\ \text { TAFL } & 5145.396 & -17753.867 & 186 & \text { L4 } & 2003 / 08 / 28 \\ \text { TAFP } & 5154.003 & -17758.997 & 440 & \text { L22 } & 2003 / 08 / 27 \\ \text { TANO } & 5154.942 & -17807.249 & 269 & \text { L4 } & 2003 / 08 / 24 \\ \text { TAPA } & 5148.932 & -17748.770 & 640 & \text { L4 } & 2003 / 08 / 27 \\ \text { TASE } & 5150.099 & -17802.222 & 682 & \text { L4 } & 2003 / 08 / 24\end{array}$


Station Latitude (N) Longitude (E) Elevation (m) Seismometer

Mount Veniaminof subnet (9 stations - 9 components)

BPBC $5635.383 \quad-15827.153 \quad 584 \quad$ L

VNFG $5617.140 \quad-15933.066 \quad 1,068 \quad$ L

VNHG $5613.267-15909.853 \quad 966 \quad$ L

VNKR $5601.871-15922.068 \quad 620 \quad$ L4

VNNF $5617.022 \quad-15918.961 \quad 1,153 \quad$ L4

VNSG $5607.549-15905.121 \quad 761 \quad$ L

VNSS $5613.600-15927.290 \quad 1,733 \quad$ L4

VNSW $5604.317-15933.508 \quad 716 \quad$ L4

$\begin{array}{lllll}\text { VNWF } & 5609.104 & -15933.733 & 1,095 & \text { L4 }\end{array}$

Westdahl Peak subnet (6 stations - 8 components)

WEBT $5435.468-16445.183 \quad 467$

WECS $5431.853-16446.653 \quad 642$

WESE $5428.389-16435.038 \quad 953$

WESN $5434.620 \quad-16434.704 \quad 549$

WESP $^{3} \quad 5428.611 \quad-16443.277 \quad 937$

WTUG $5450.847 \quad-16423.117 \quad 636$

Mount Wrangell subnet (4 stations - 6 components)

WANC $6200.189 \quad-144 \quad 4.195$

WASW $6155.692 \quad-14410.346$

WAZA

$6204.506-1449.132$

4,190

2,196

2,531

$\mathrm{L} 4$

L4

L4

L4

L22

L4

4

AVO Regional stations (10 stations - 12 components)

$\begin{array}{lllll}\text { ADAG }^{3} & 5158.812 & -17636.104 & 286 & \text { L4 } \\ \text { AMKA }^{3} & 5122.70 & 17918.11 & 116 & \text { Tri-40 } \\ \text { BGM } & 5923.56 & -15513.76 & 625 & \text { L4 } \\ \text { BGR } & 6045.45 & -15225.06 & 985 & \text { L4 } \\ \text { ETKA } & 5151.712 & -17624.351 & 290 & \text { L4 } \\ \text { KC01 } & 5210.578 & -17529.493 & 32 & \text { CMG-6TD } \\ \text { MMN } & 5911.11 & -15420.20 & 442 & \text { S13 } \\ \text { OPT } & 5939.192 & -15313.796 & 602 & \text { S13 } \\ \text { PDB } & 5947.09 & -15411.37 & 360 & \text { L4 } \\ \text { STLK } & 6129.926 & -15149.963 & 945 & \text { L4 } \\ \text { SYI } & 5836.607 & -15223.485 & 149 & \text { L4 }\end{array}$

$1999 / 09 / 15$

$2005 / 10 / 14$

$1978 / 09 / 08$

$1991 / 07 / 01$

$1999 / 09 / 15$

$2009 / 06 / 12$

$1981 / 08 / 22$

$1974 / 00 / 00$

$1978 / 09 / 09$

1997/09/01

1997/09/01

$2002 / 10 / 03$

$2002 / 02 / 06$

$2002 / 02 / 06$

$2002 / 02 / 06$

$2002 / 06 / 20$

$2002 / 02 / 06$

$2002 / 02 / 06$

$2002 / 06 / 20$

2002/02/06

$2008 / 08 / 02$

2008/08/03

$1998 / 08 / 28$

$1998 / 10 / 17$

2008/07/31

$1998 / 10 / 17$

$\underline{\text { Close date }}$

$2000 / 07 / 31$

$2000 / / 07 / 31$

2001/08/03 
Station Latitude $(\mathrm{N})$ Longitude $(\mathrm{E})$ Elevation $(\mathrm{m})$ Seismometer

\begin{tabular}{|c|c|c|c|c|}
\hline \multicolumn{5}{|c|}{ AEIC, Global Seismograph Network, and WCATI } \\
\hline ADK & 5153.022 & -17641.064 & 116 & \\
\hline AKUT & 548.112 & -17411.730 & 55 & \\
\hline ATKA & 5212.162 & -17411.730 & 55 & \\
\hline BAL & 6102.172 & -14220.652 & 1,541 & \\
\hline BMR & 6058.092 & -14436.180 & 842 & \\
\hline $\mathrm{CHGN}$ & 5618.084 & -15924.852 & 16 & \\
\hline CUT & 6224.282 & -15016.164 & 168 & \\
\hline DIV & 6107.782 & -14546.368 & 939 & \\
\hline FALS & 5451.438 & -16324.930 & 46 & \\
\hline GLB & 6126.508 & -14348.630 & 853 & \\
\hline HOM & 5939.498 & -15138.592 & 198 & \\
\hline KDAK & 5746.968 & -15235.010 & 152 & \\
\hline KLU & 6129.580 & -14555.236 & 1,021 & \\
\hline MENT & 6256.280 & -14343.164 & 702 & \\
\hline NIKH & 5258.386 & -14358.032 & 507 & \\
\hline NIKO & 5256.328 & -16852.002 & 80 & \\
\hline NKA & 6044.580 & -15114.274 & 100 & \\
\hline PAX & 6258.224 & -14528.056 & 1,130 & \\
\hline PLR & 6135.532 & $-149 \quad 7.842$ & & 100 \\
\hline PMR & 6135.532 & -1497.848 & 100 & \\
\hline RC01 & 6105.376 & -14944.208 & 383 & \\
\hline SAW & 6148.456 & -14836.104 & 782 & \\
\hline SCM & 6150.004 & -14719.644 & 1,039 & \\
\hline SKN & 6158.836 & -15131.752 & 603 & \\
\hline SLK & 6030.738 & -15013.254 & 655 & \\
\hline SSN & 6127.840 & -15044.664 & 1,293 & \\
\hline SWD & 6006.294 & -149 27.042 & 68 & \\
\hline UNV & 5350.790 & -16630.120 & 67 & \\
\hline
\end{tabular}

\section{Open date Close date}

$\begin{array}{ll}1966 / 01 / 01 & - \\ 2002 / 10 / 03 & - \\ 2002 / 10 / 03 & - \\ 1973 / 08 / 24 & - \\ 1979 / 08 / 19 & - \\ 2004 / 10 / 20 & - \\ 1986 / 07 / 18 & - \\ 1999 / 01 / 07 & - \\ 2002 / 06 / 19 & - \\ 1973 / 08 / 25 & - \\ 1981 / 01 / 01 & - \\ 1997 / 06 / 09 & - \\ 1972 / 07 / 23 & - \\ 2004 / 10 / 20 & - \\ 2007 / 06 / 21 & - \\ 2002 / 11 / 22 & - \\ 1971 / 09 / 13 & - \\ 1969 / 07 / 01 & - \\ 1984 / 09 / 21 & - \\ 1999 / 08 / 11 & - \\ 1998 / 08 / 07 & - \\ 1973 / 08 / 31 & - \\ 1966 / 06 / 01 & - \\ 1972 / 08 / 09 & - \\ 1984 / 07 / 30 & - \\ 1972 / 08 / 16 & - \\ 2001 / 06 / 02 & - \\ 1999 / 02 / 19 & -\end{array}$
Station Codes: $\quad 3$ Three-component station
P Pressure sensor collocated with seismometer
R Station removed in 2009
* Seismic station has a both a high-gain and low-gain vertical component
\# Temporary three-component broadband station

$\begin{array}{lll}\begin{array}{l}\text { Seismometer Codes: } \\ \text { seismometer }\end{array} & \text { CMG-40T: } \quad \text { Guralp CMG-40T three-component broadband } \\ & \text { CMG-5T: } & \text { Guralp CMG-5T three-component broadband seismometer } \\ \text { CMG-6TD: } & \text { Guralp CMG-6TD three-component broadband seismometer } \\ \text { CMG-3ESP: } & \text { Guralp CMG-3ESP three-component broadband seismometer } \\ \text { KS-54000: } & \text { three-component broadband seismometer } \\ \text { L4, L4-3D: } & \text { Mark Products L4 or L4-3D single-component short-period seismometer } \\ \text { L22: } & \text { Mark Products L22 three-component short-period seismometer } \\ \text { S13: } & \text { Teledyne Geotech S13 single-component short-period seismometer } \\ \text { SM: } & \text { Ref Tek 130-ANSS/02 strong motion seismometer } \\ \text { STS-1: } & \text { Streckeisen STS-1H/VBB broadband seismometer } \\ \text { STS-2: } & \text { Streckeisen STS-2 broadband seismometer } \\ \text { Tri-40: } & \text { Nanometrics Trillium 40 three-component broadband seismometer }\end{array}$


50 Catalog of Earthquake Hypocenters at Alaskan Volcanoes: January 1 through December 31, 2009

This page left intentionally blank. 


\section{Appendix C. Locations (datum NAD27) of the AVO Seismograph Stations in 2009.}

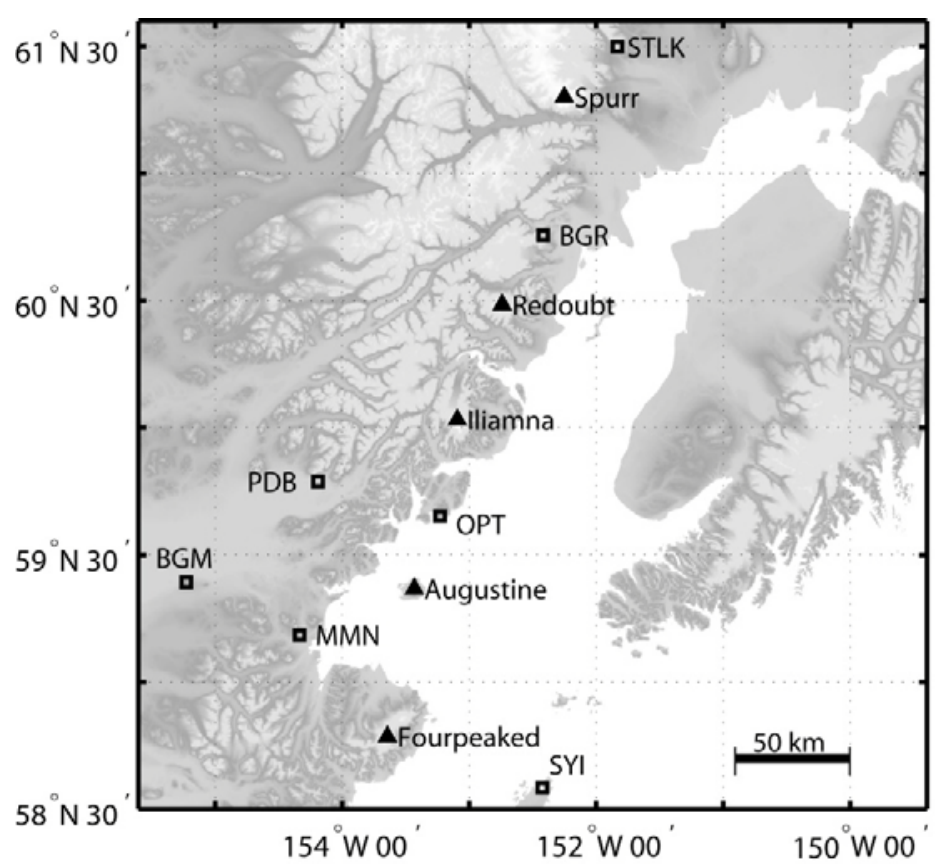

Figure C1. Regional AVO seismograph stations in Cook Inlet in 2009. Permanent stations are shown by open squares. Closed triangles show volcanic centers.

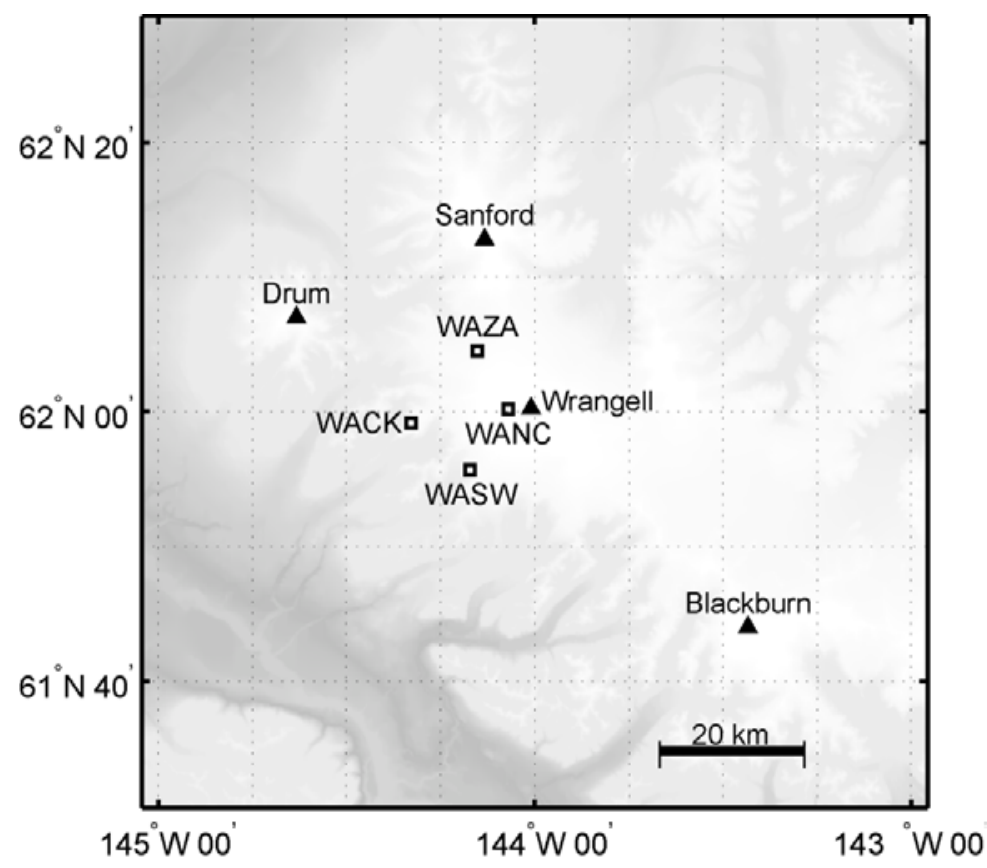

Figure C2. AV0 seismograph stations near Mount Wrangell in 2009. Permanent stations are shown by open squares. Closed triangles show volcanic centers. 


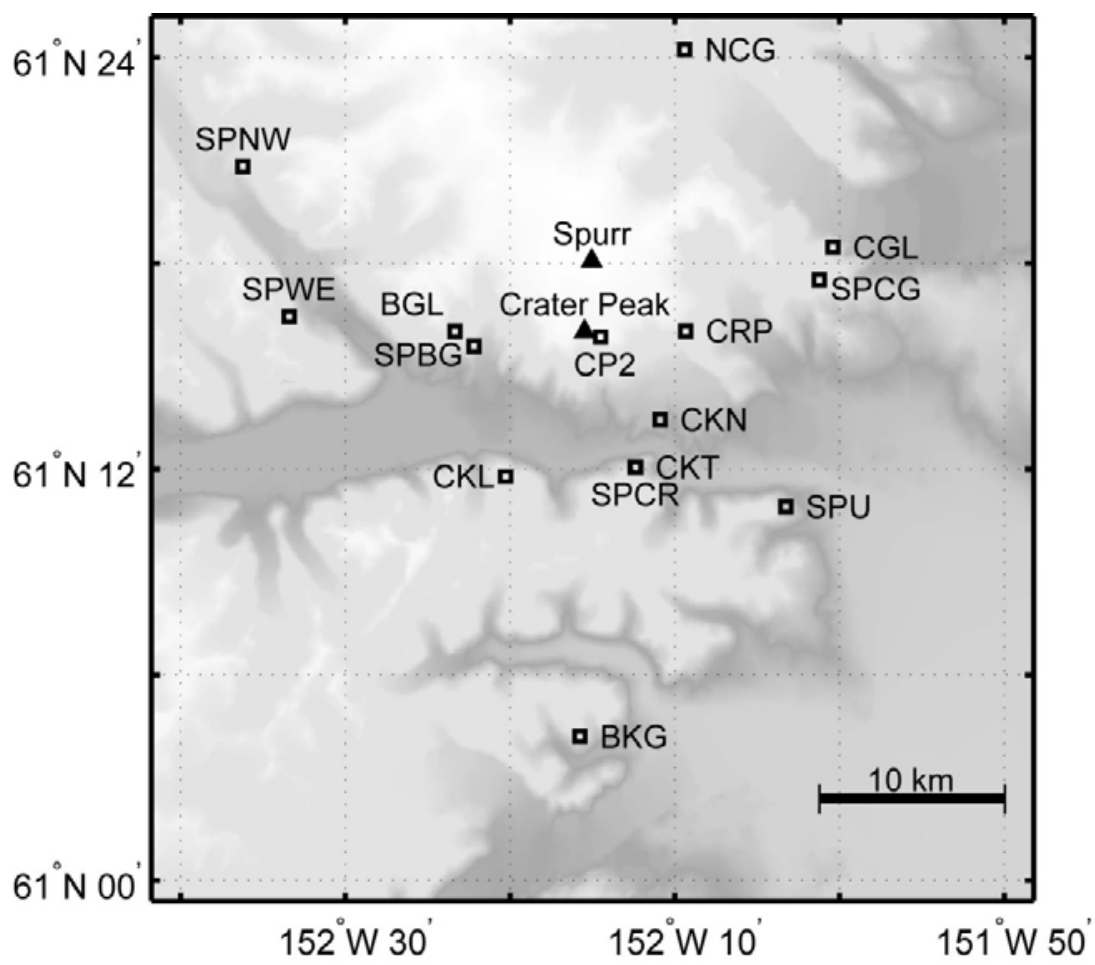

Figure C3. AV0 seismograph stations near Mount Spurr in 2009. Permanent stations are shown by open squares. Closed triangles show volcanic centers.

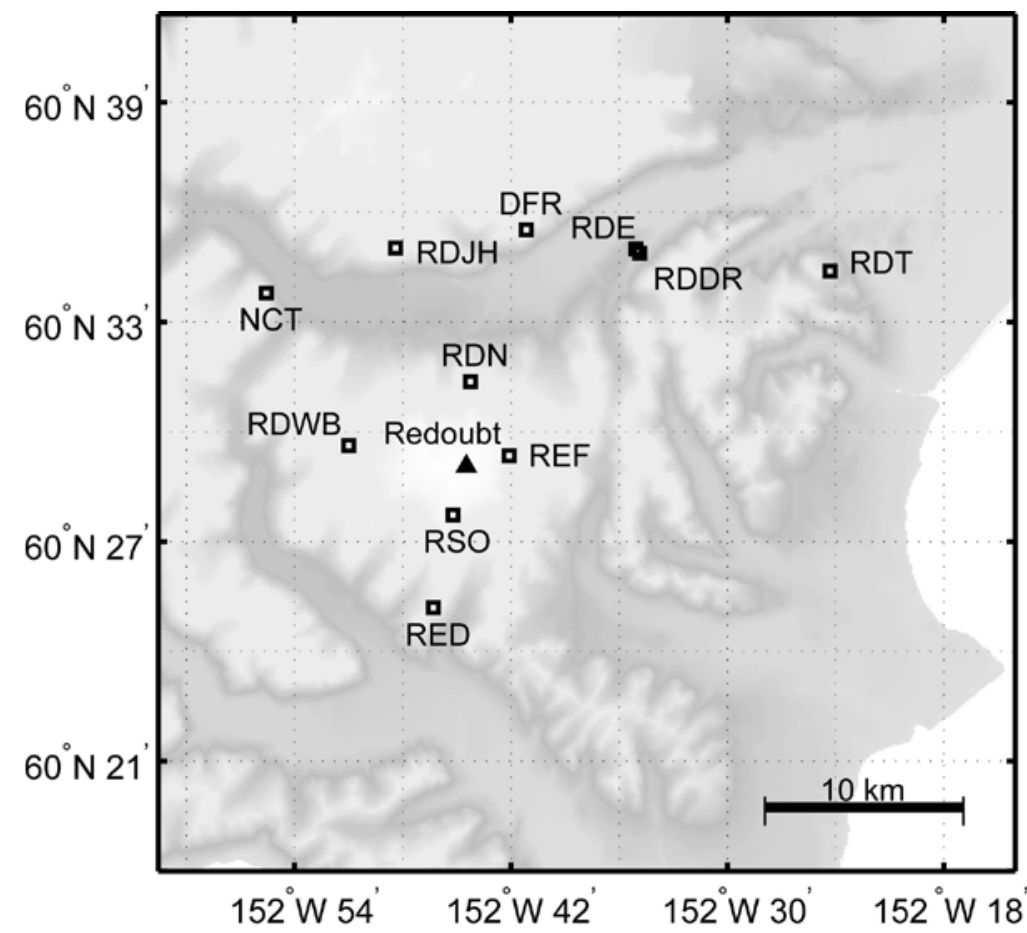

Figure C4. AVO seismograph stations near Redoubt Volcano in 2009. Permanent stations are shown by open squares. Closed triangles show volcanic centers. 


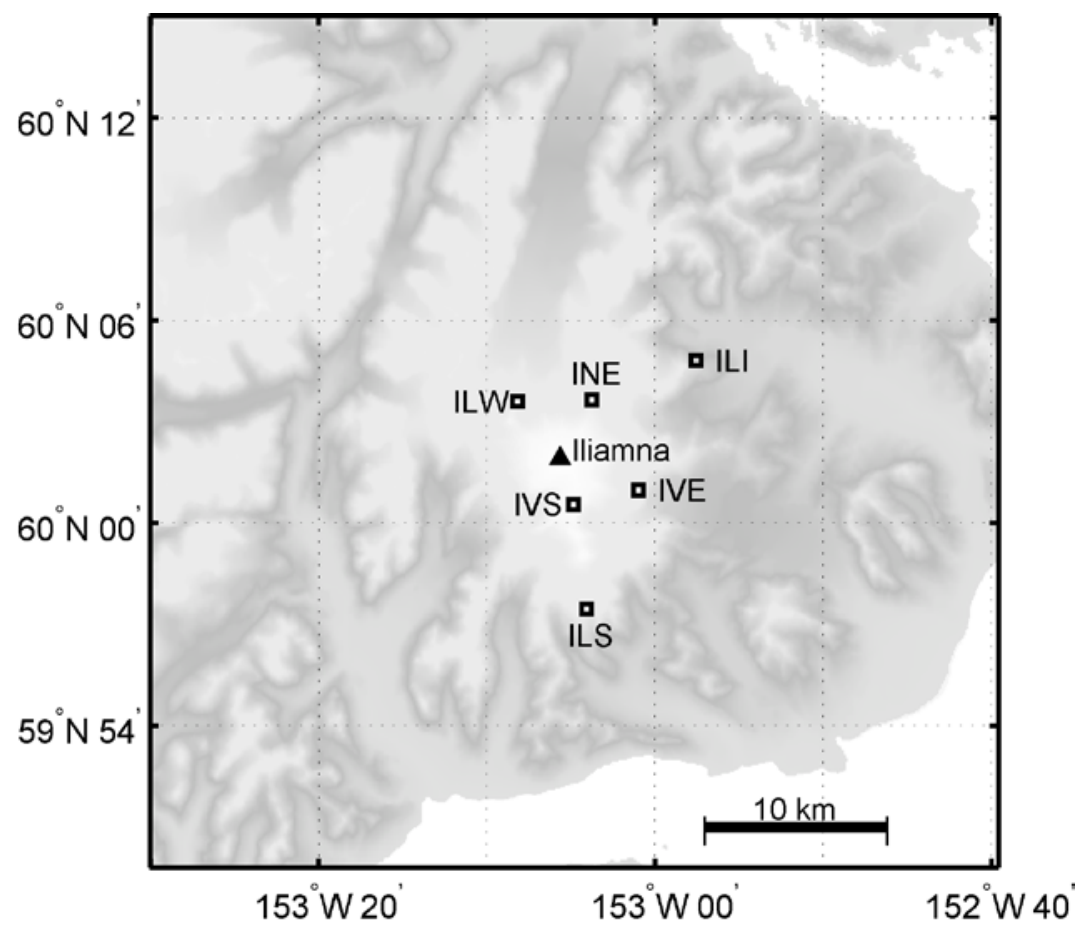

Figure C5. AV0 seismograph stations near lliamna Volcano in 2009. Permanent stations are shown by open squares. Closed triangles show volcanic centers.

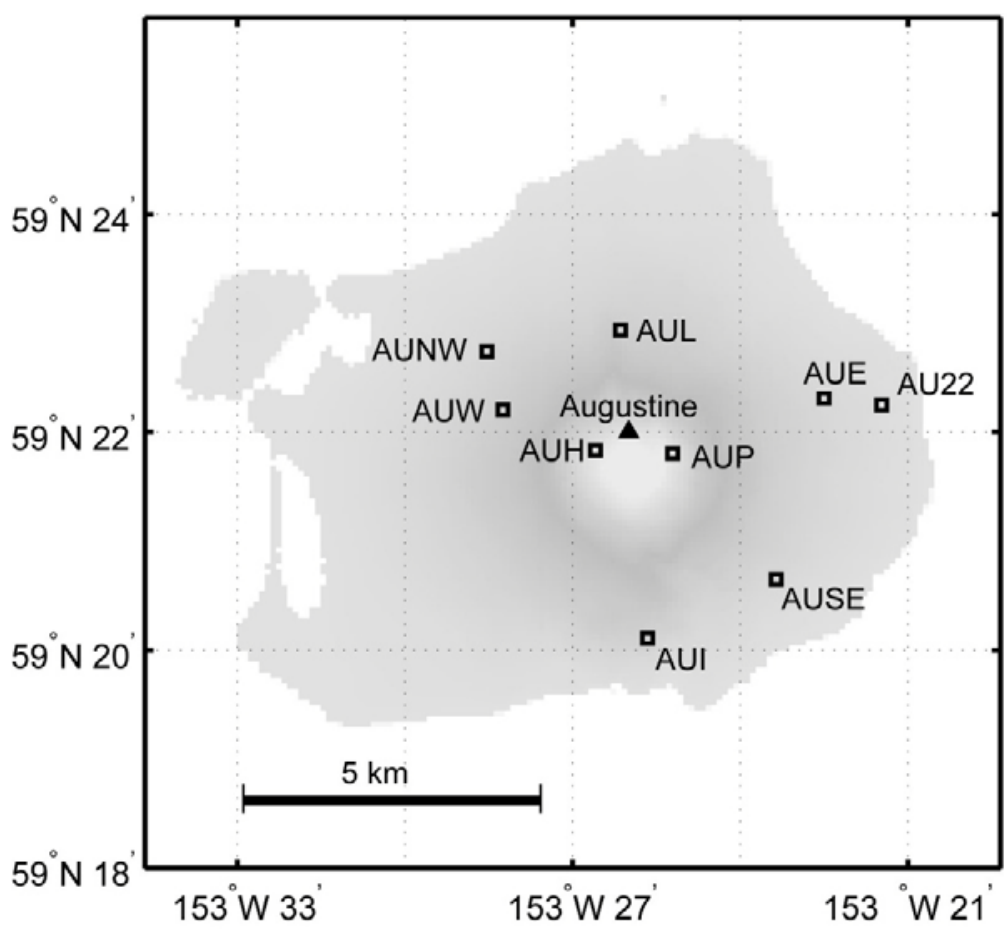

Figure C6. AVO seismograph stations near Augustine Volcano in 2009. Permanent stations are shown by open squares. Closed triangles show volcanic centers. 


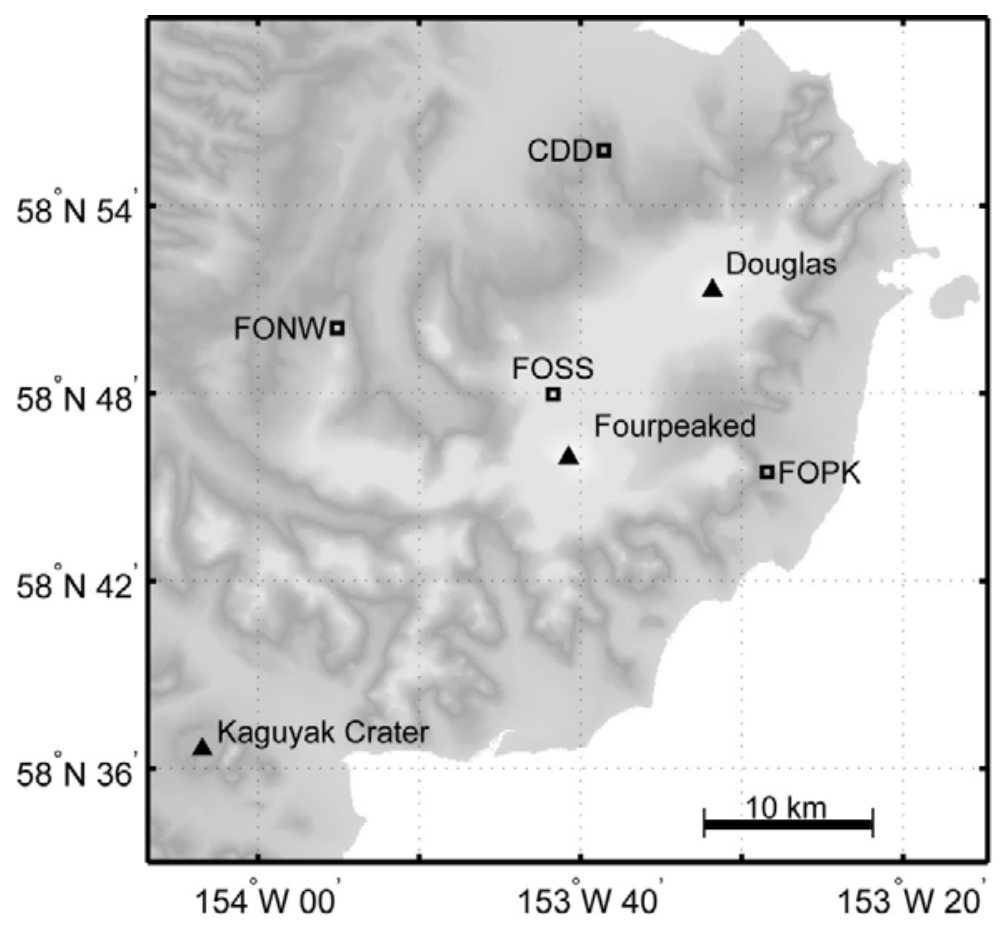

Figure C7. AVO seismograph stations near Fourpeaked Mountain in 2009. Permanent stations are shown by open squares. Closed triangles show volcanic centers.

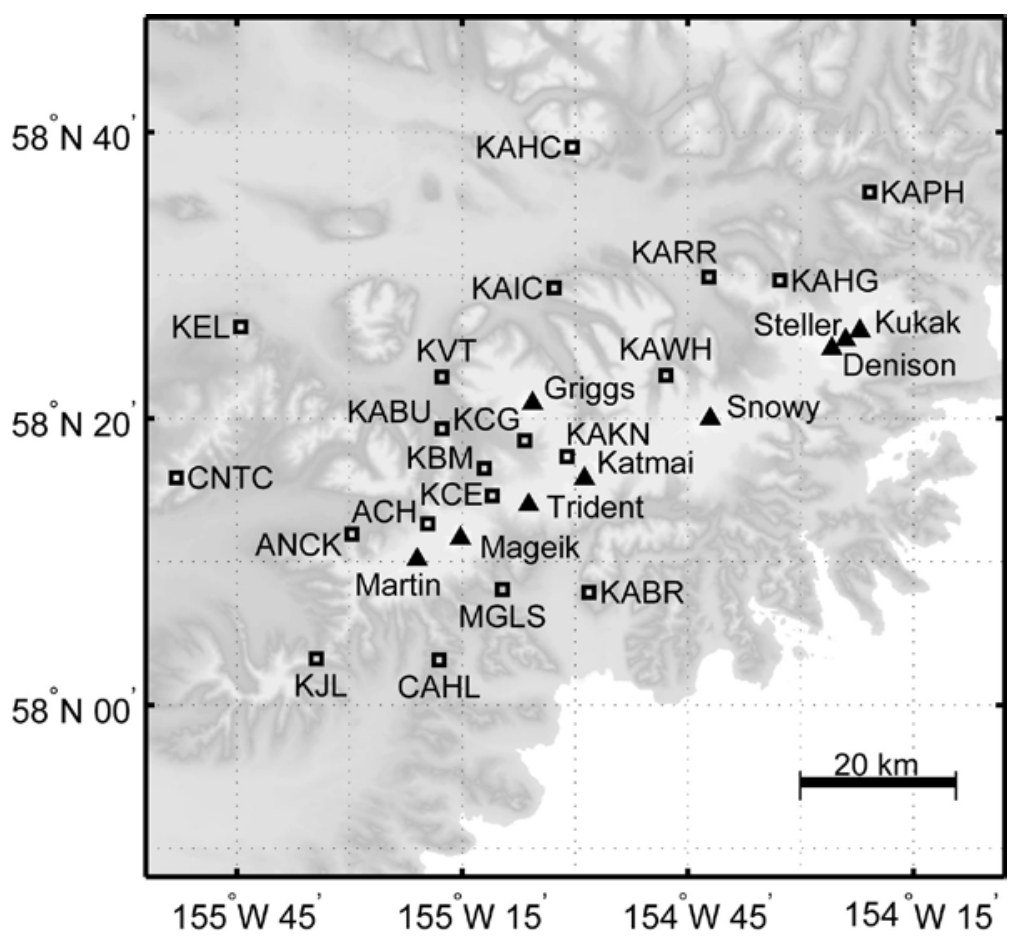

Figure C8. AVO seismograph stations near the Katmai volcanic cluster in 2009. Permanent stations are shown by open squares. Closed triangles show volcanic centers. 


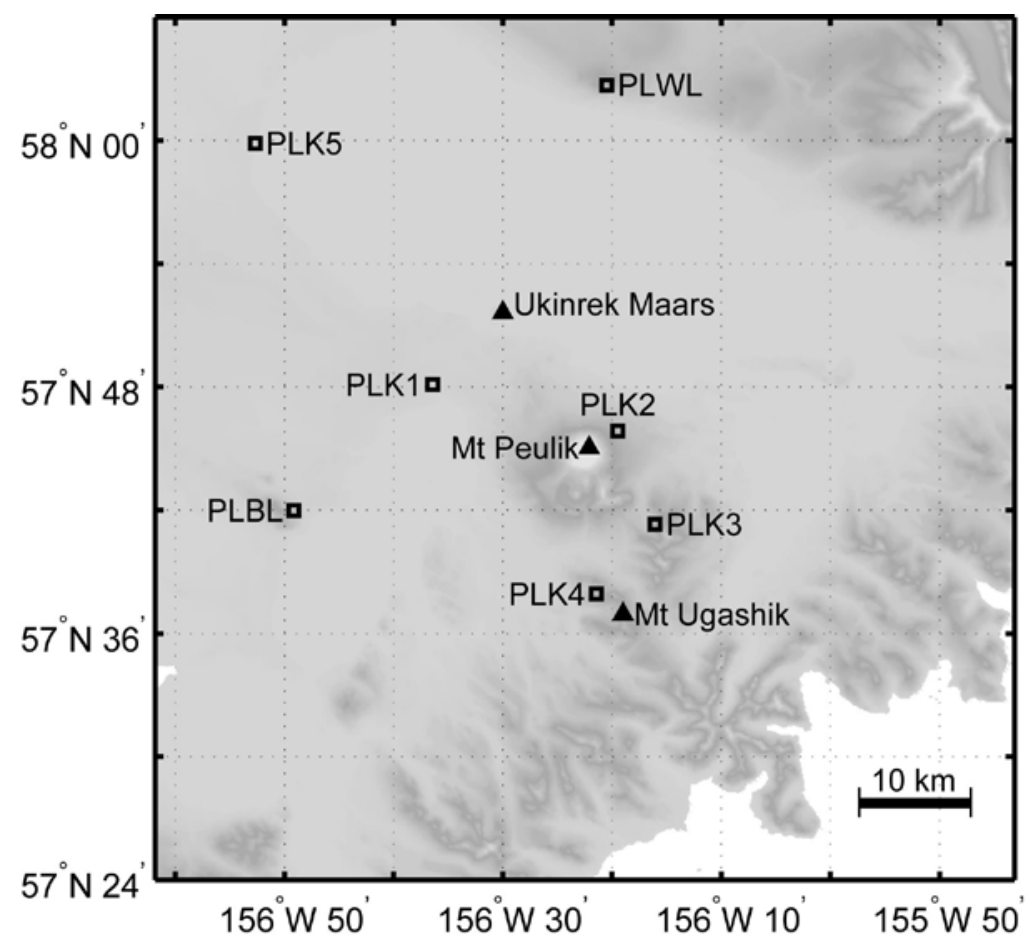

Figure C9. AVO seismograph stations near the Mount Peulik in 2009. Permanent stations are shown by open squares. Closed triangles show volcanic centers.

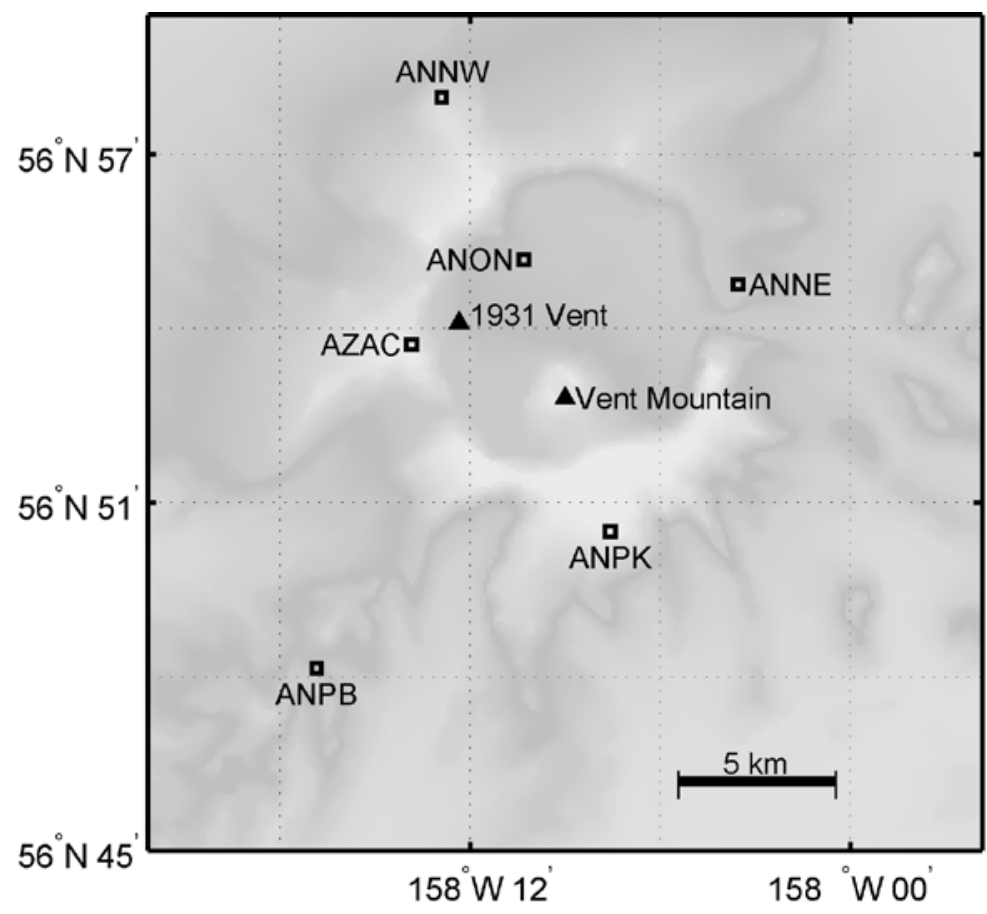

Figure C10. AVO seismograph stations near Aniakchak Crater in 2009. Permanent stations are shown by open squares. Closed triangles show volcanic centers. 


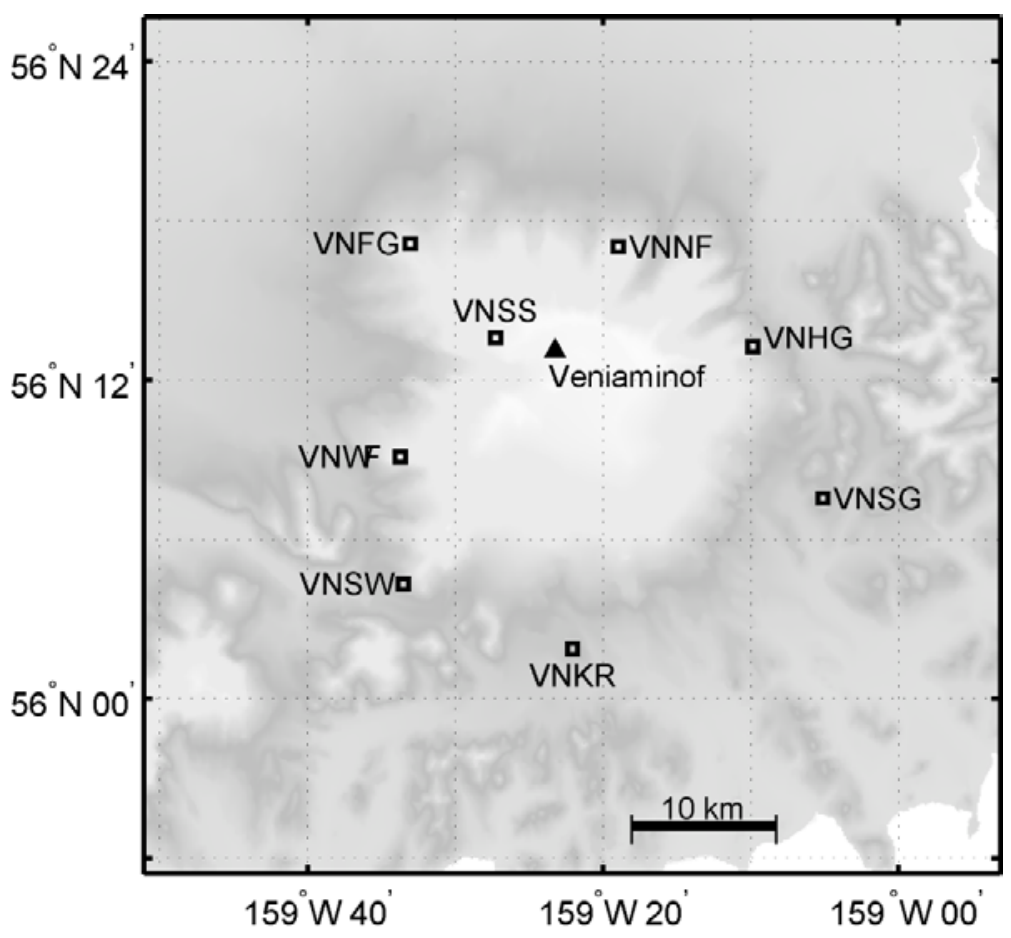

Figure C11. AVO seismograph stations near Mount Veniaminof in 2009. Seismograph station BPBC is not shown and is located $70 \mathrm{~km}$ northeast of Mount Veniaminof. Permanent stations are shown by open squares. Closed triangles show volcanic centers.

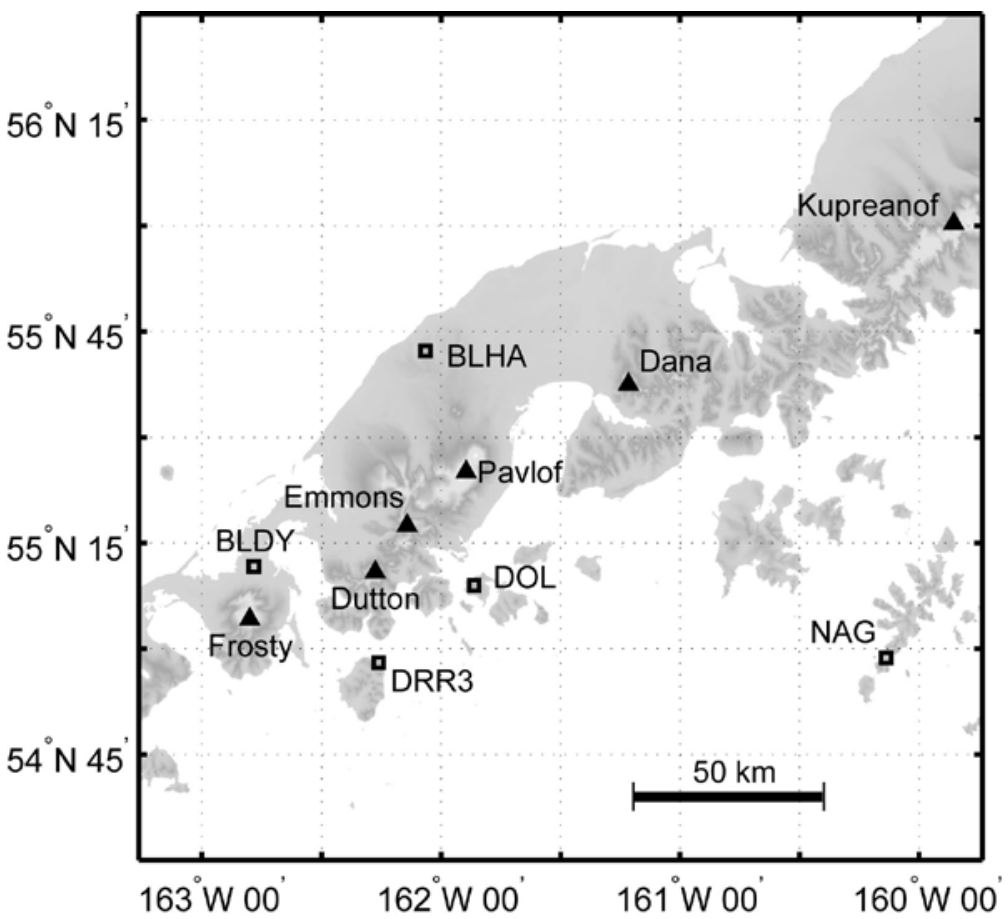

Figure C12. Regional AVO seismograph stations on the Alaska Peninsula in 2009. Permanent stations are shown by open squares. Closed triangles show volcanic centers. 


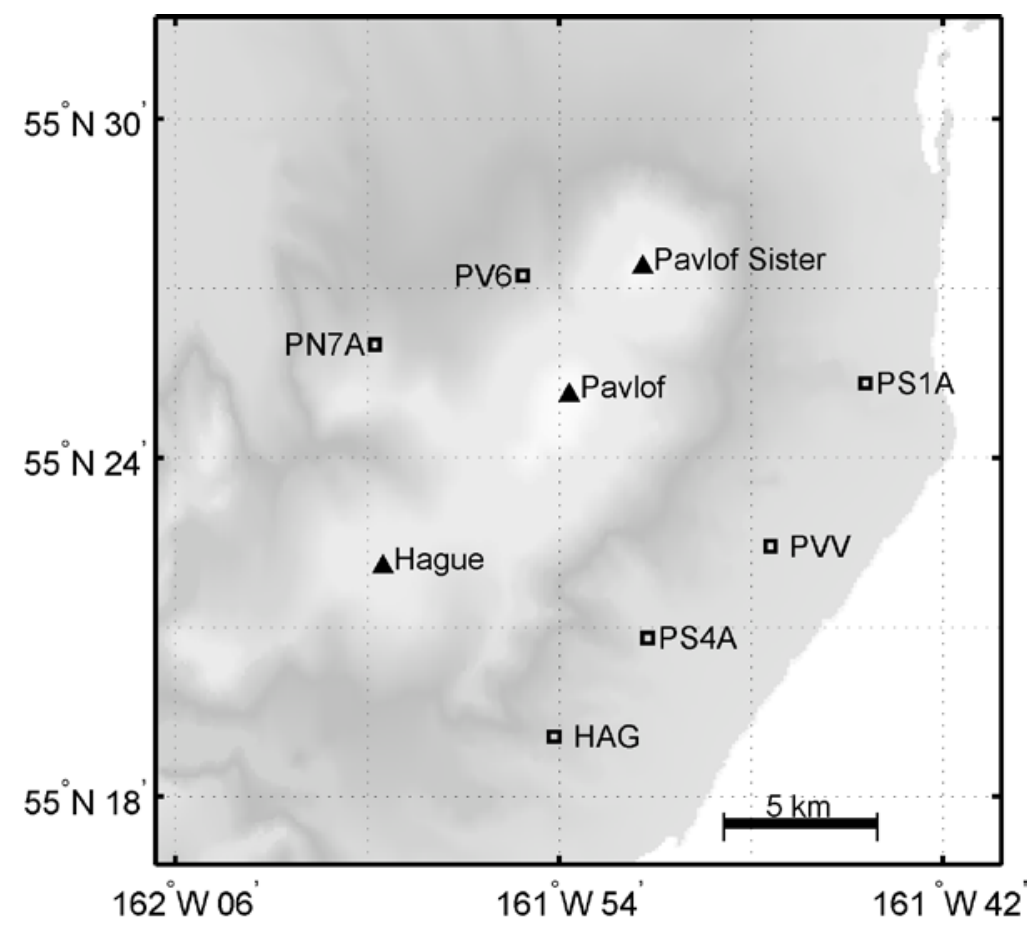

Figure C13. AVO seismograph stations near Pavlof Volcano in 2009. Permanent stations are shown by open squares. Closed triangles show volcanic centers.

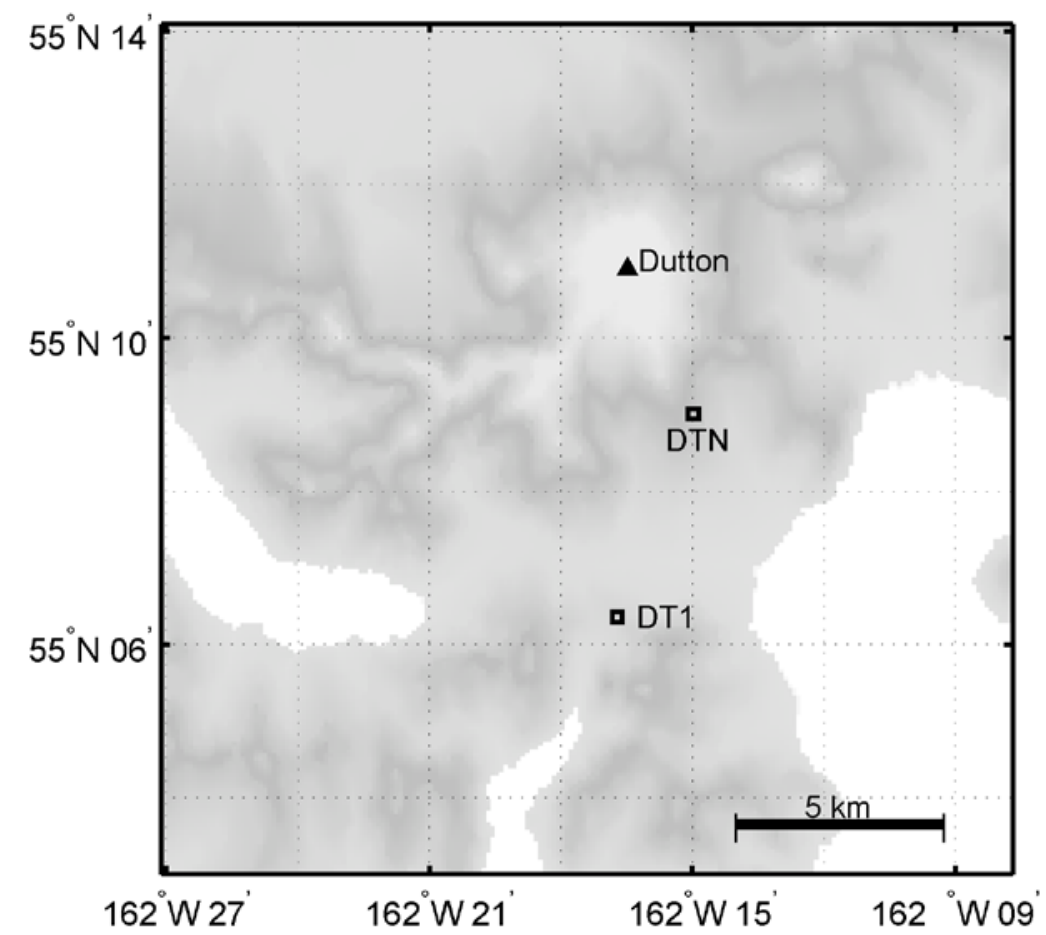

Figure C14. AVO seismograph stations near Mount Dutton in 2009. Permanent stations are shown by open squares. Closed triangles show volcanic centers. 


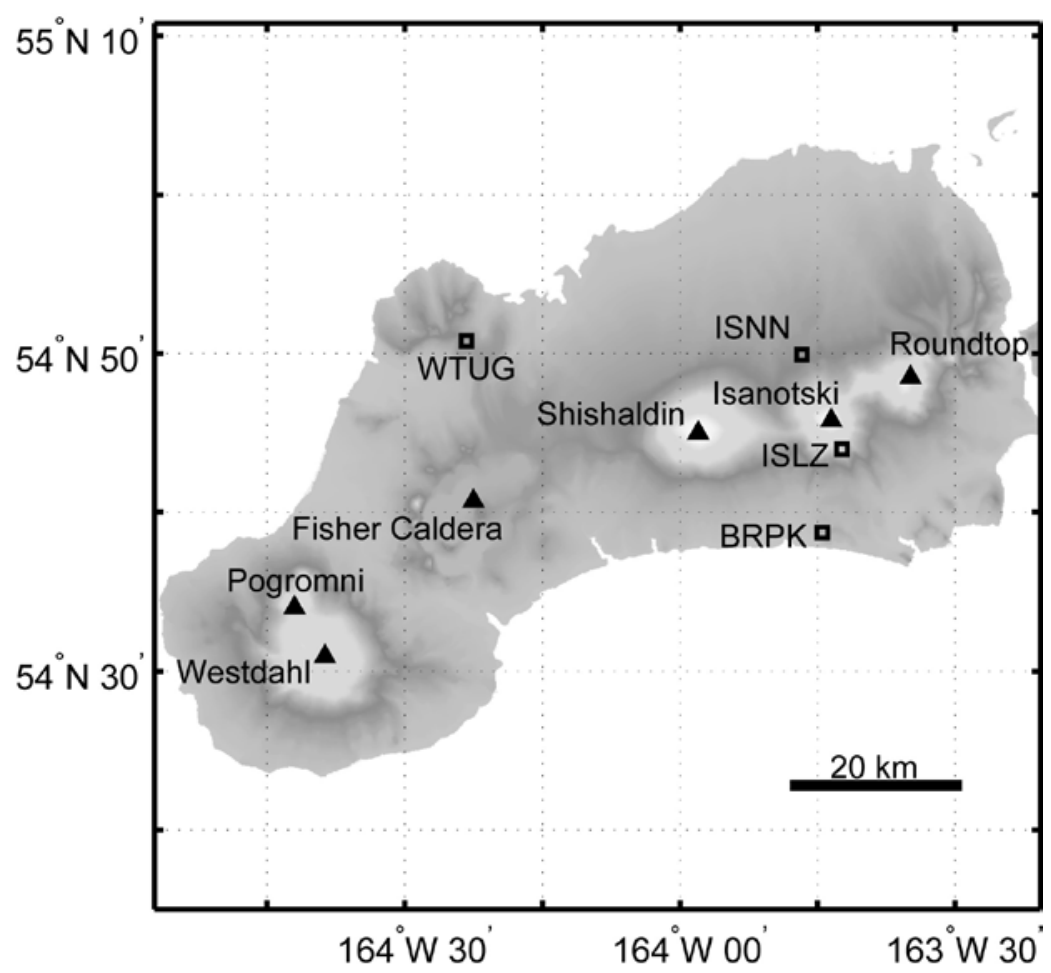

Figure C15. Regional AVO seismograph stations on Unimak Island in 2009. Permanent stations are shown by open squares. Closed triangles show volcanic centers.

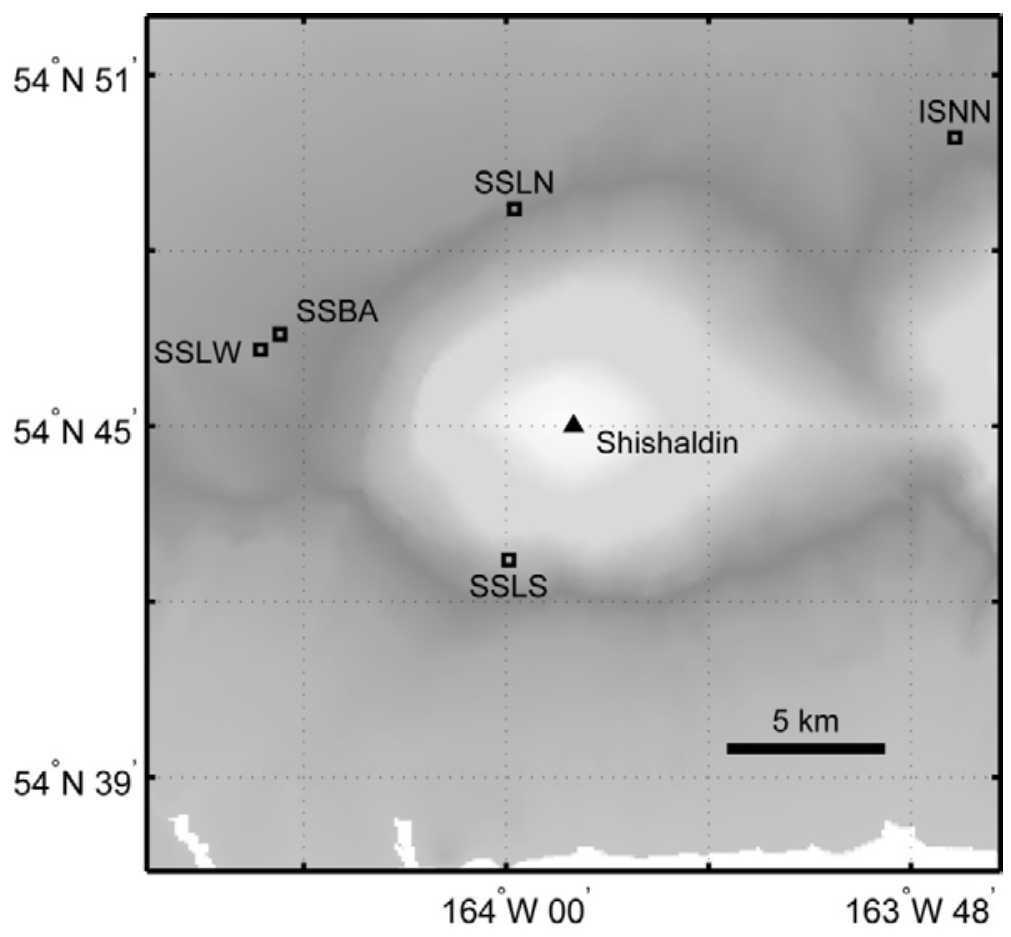

Figure C16. AVO seismograph stations near Shishaldin Volcano in 2009. Permanent stations are shown by open squares. Closed triangles show volcanic centers. 


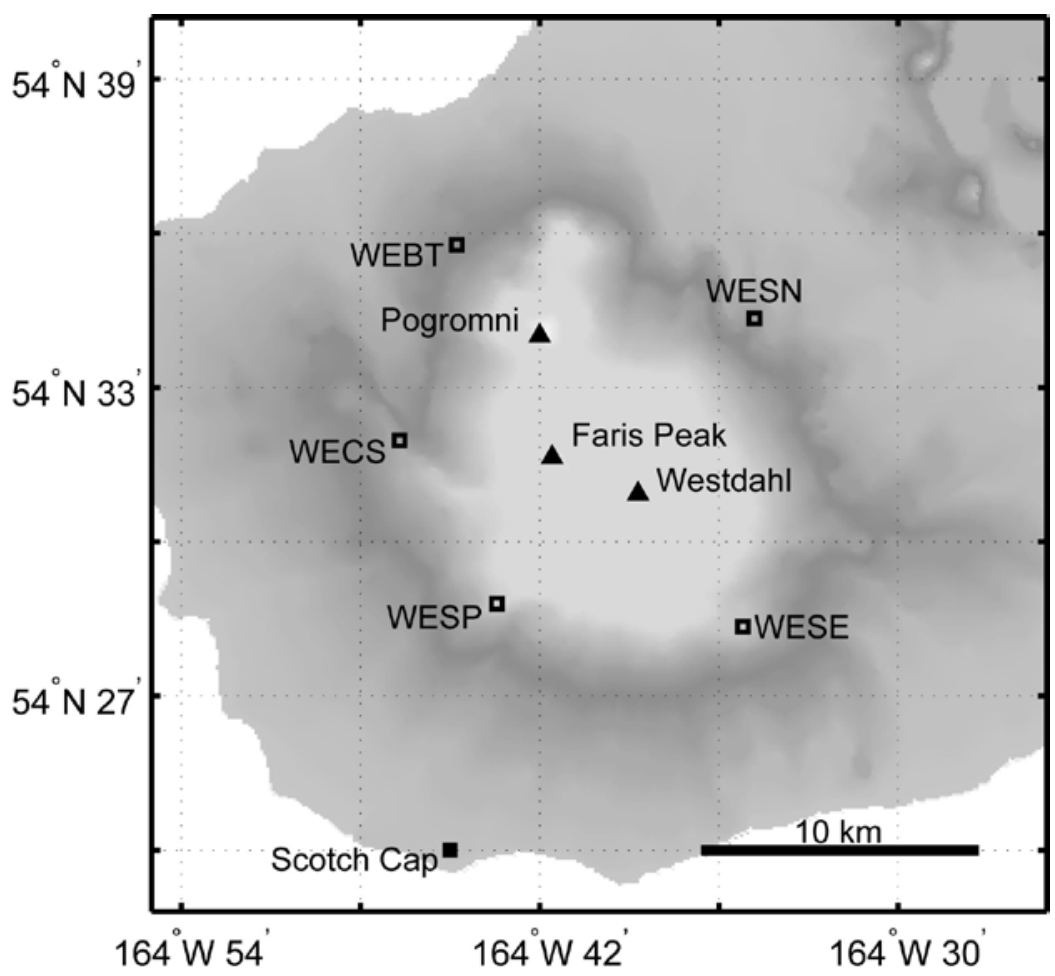

Figure C17. AVO seismograph stations near Westdahl Peak in 2009. Permanent stations are shown by open squares. Closed triangles show volcanic centers.

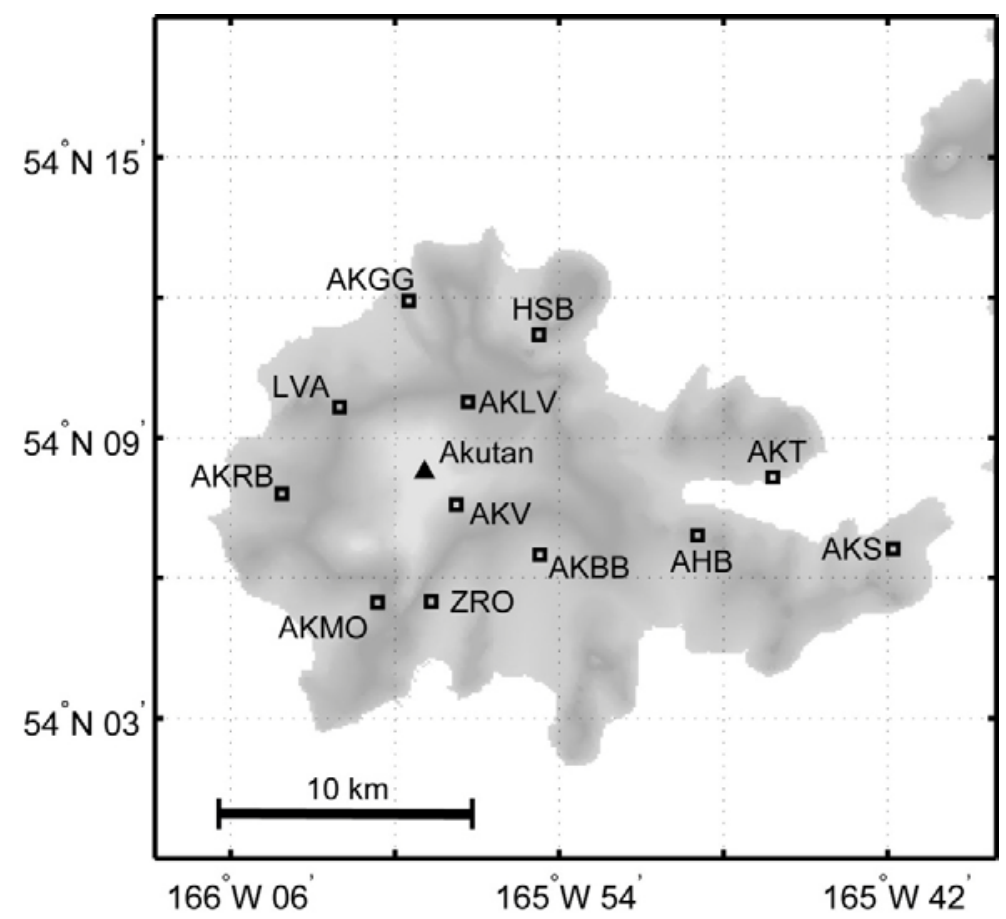

Figure C18. AV0 seismograph stations near Akutan Peak in 2009. Permanent stations are shown by open squares. Closed triangles show volcanic centers. 


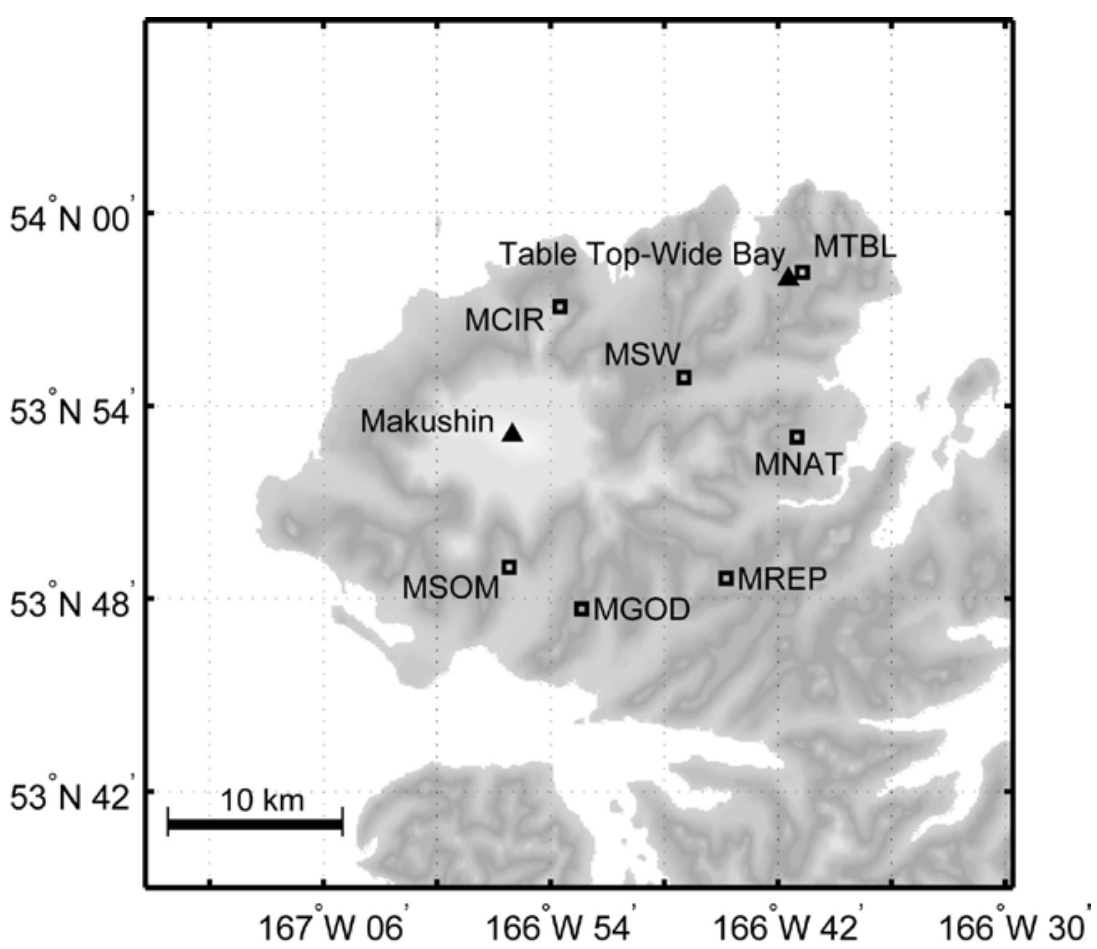

Figure C19. AVO seismograph stations near Makushin Volcano in 2009. Permanent stations are shown by open squares. Closed triangles show volcanic centers.

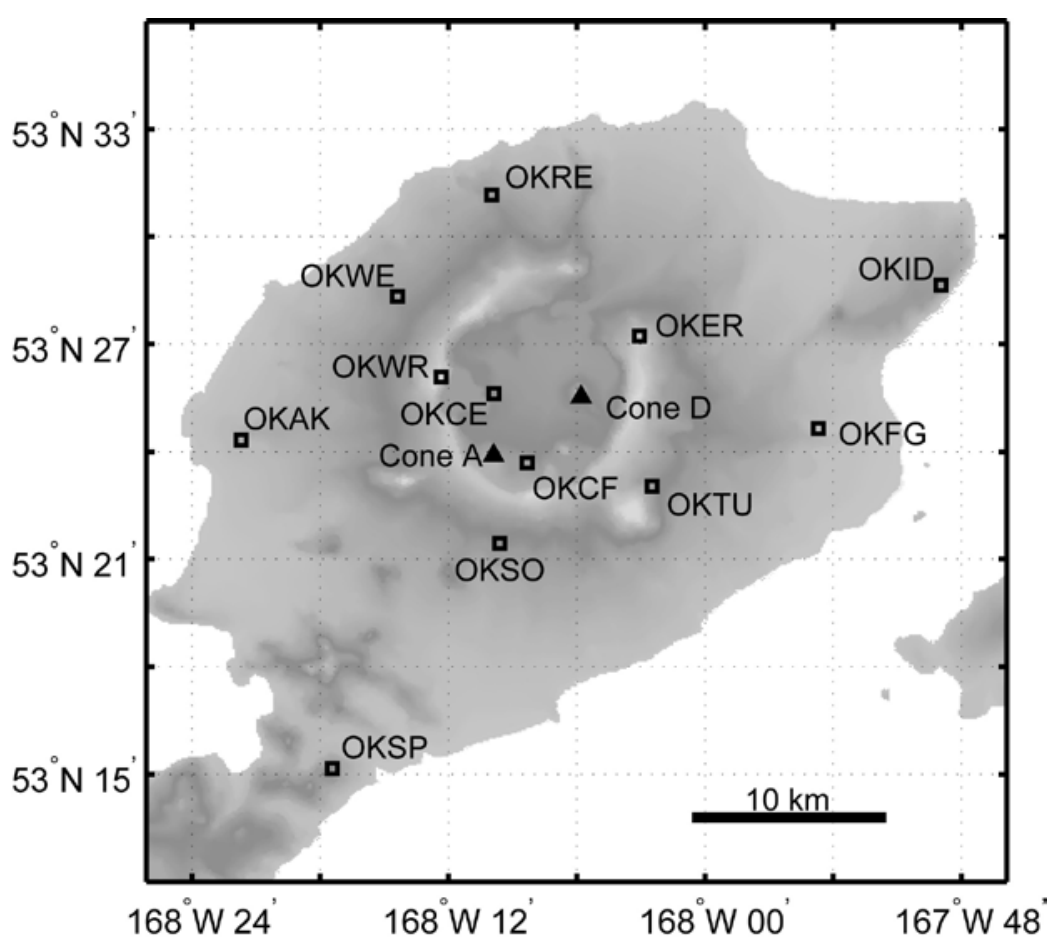

Figure C20. AV0 seismograph stations near Okmok Volcano in 2009. Permanent stations are shown by open squares. Closed triangles show volcanic centers. 


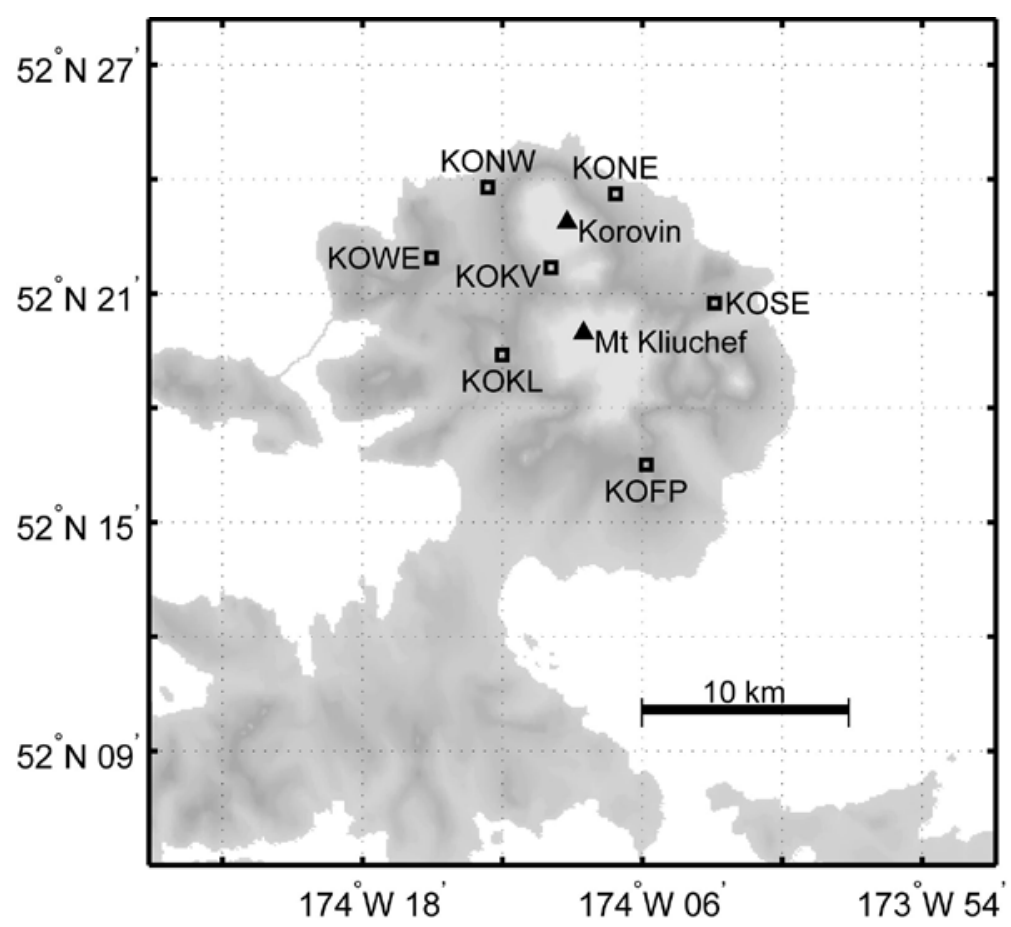

Figure C21. AVO seismograph stations on Atka Island in 2009. Permanent stations are shown by open squares. Closed triangles show volcanic centers.

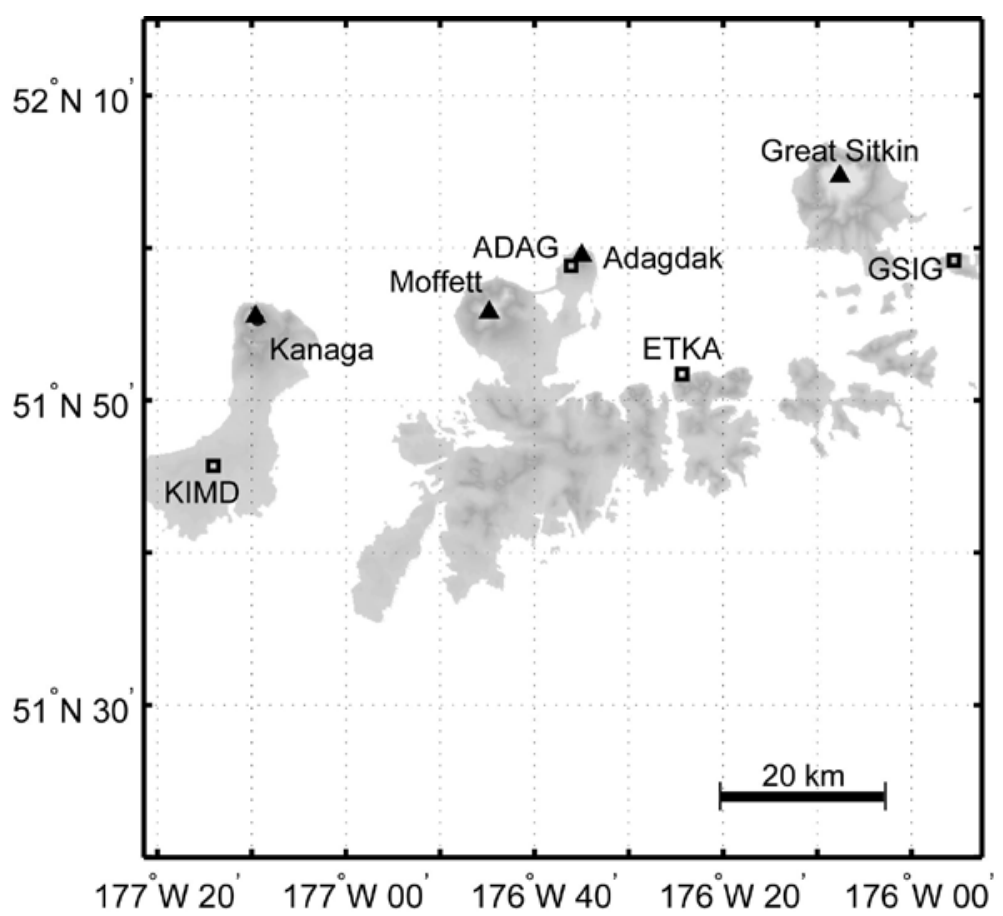

Figure C22. Regional AVO seismograph stations around Adak Island in 2009. Permanent stations are shown by open squares. Closed triangles show volcanic centers. 


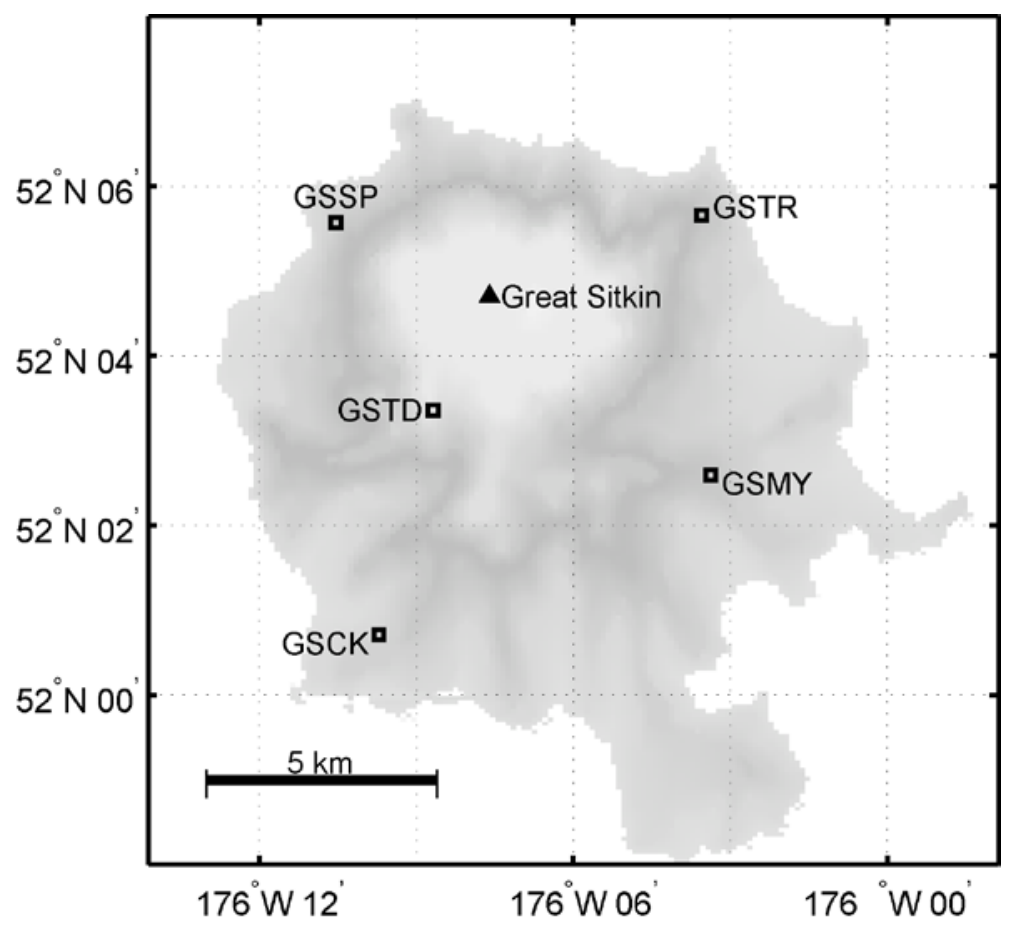

Figure C23. AVO seismograph stations near Great Sitkin Volcano in 2009. Permanent stations are shown by open squares. Closed triangles show volcanic centers.

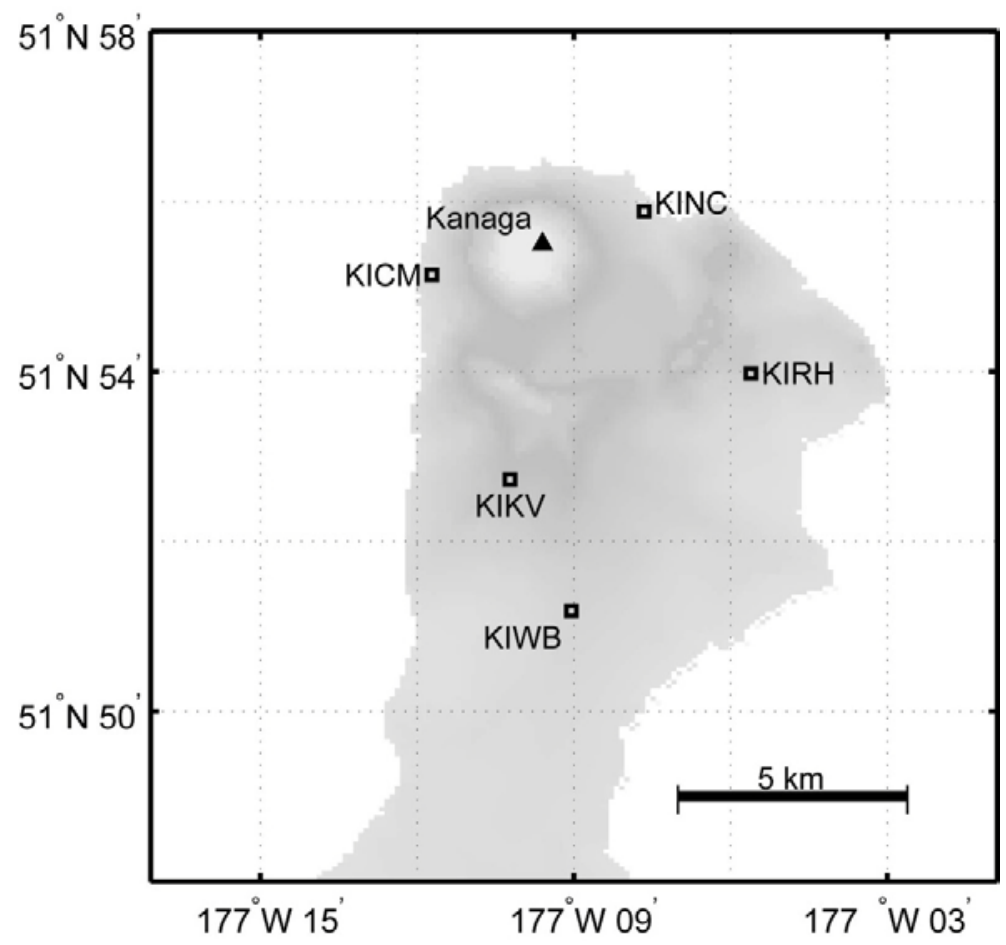

Figure C24. AVO seismograph stations near Kanaga Volcano in 2009. Permanent stations are shown by open squares. Closed triangles show volcanic centers. 


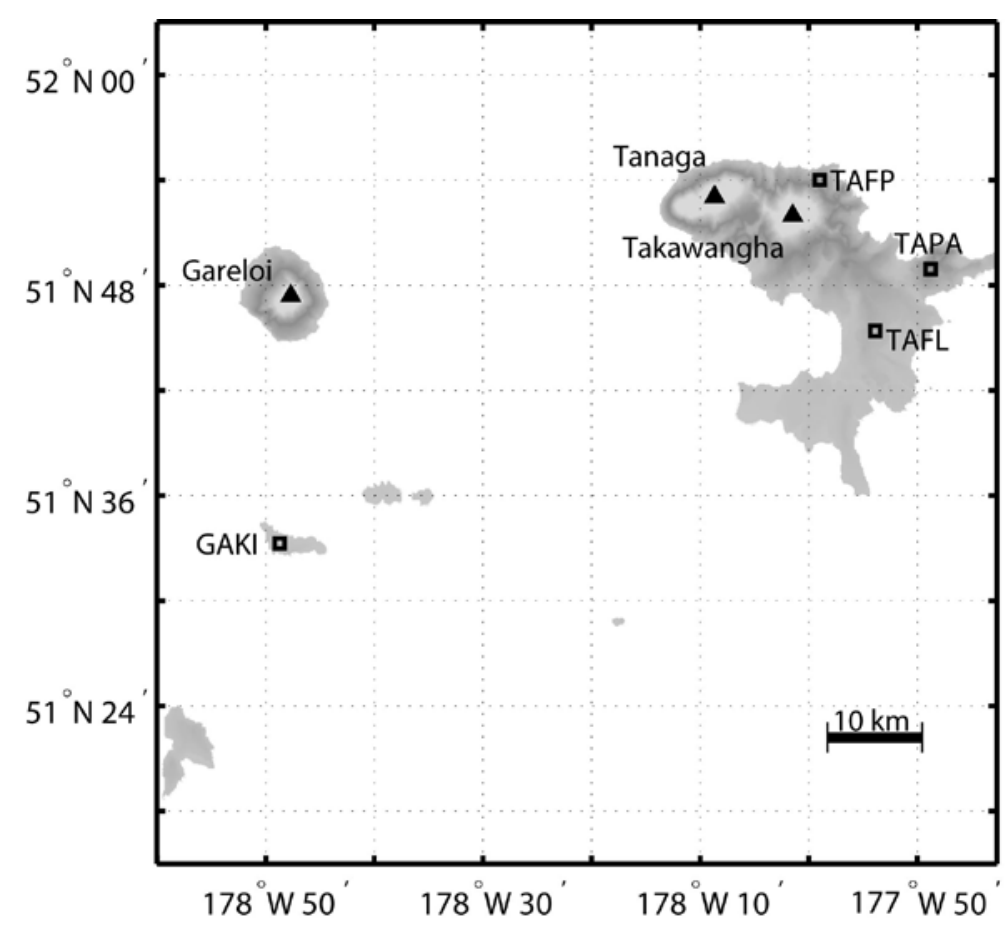

Figure C25. Regional AV0 seismograph stations around Tanaga Volcano and Mount Gareloi in 2009. Permanent stations are shown by open squares. Closed triangles show volcanic centers.

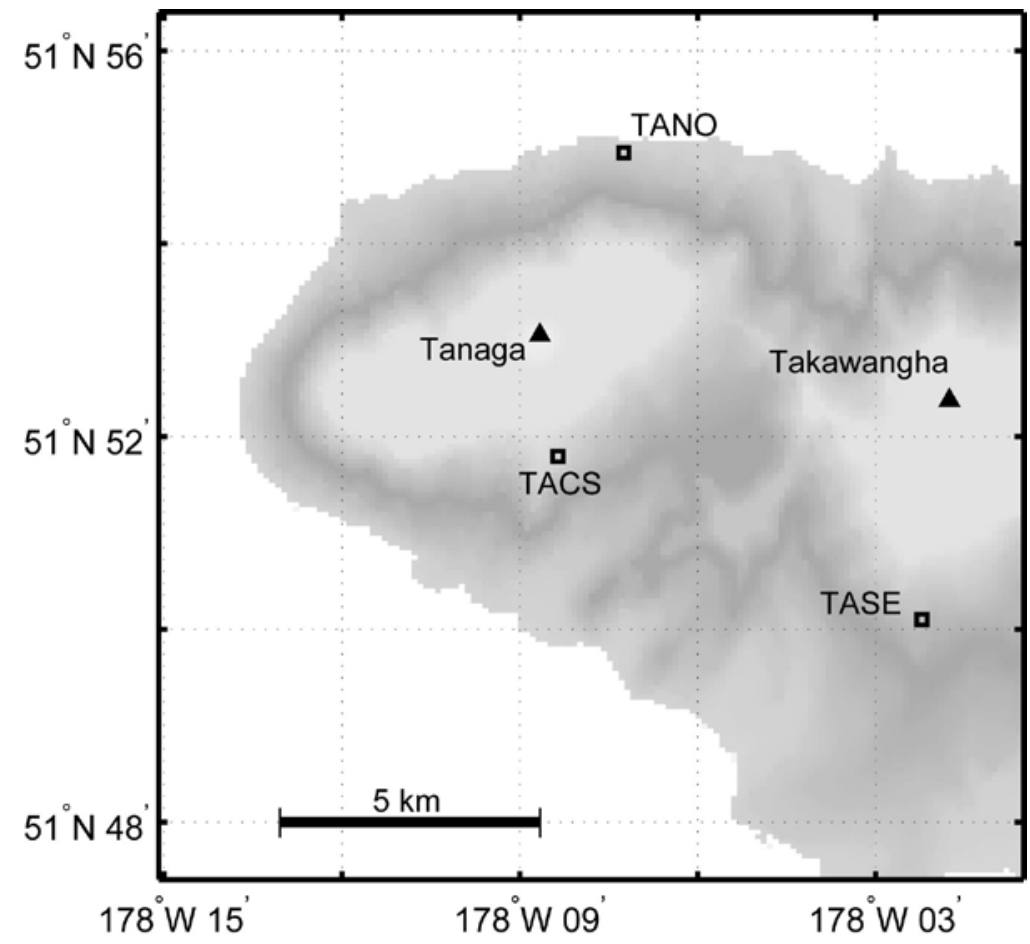

Figure C26. AVO seismograph stations near Tanaga Volcano in 2009. Permanent stations are shown by open squares. Closed triangles show volcanic centers. 


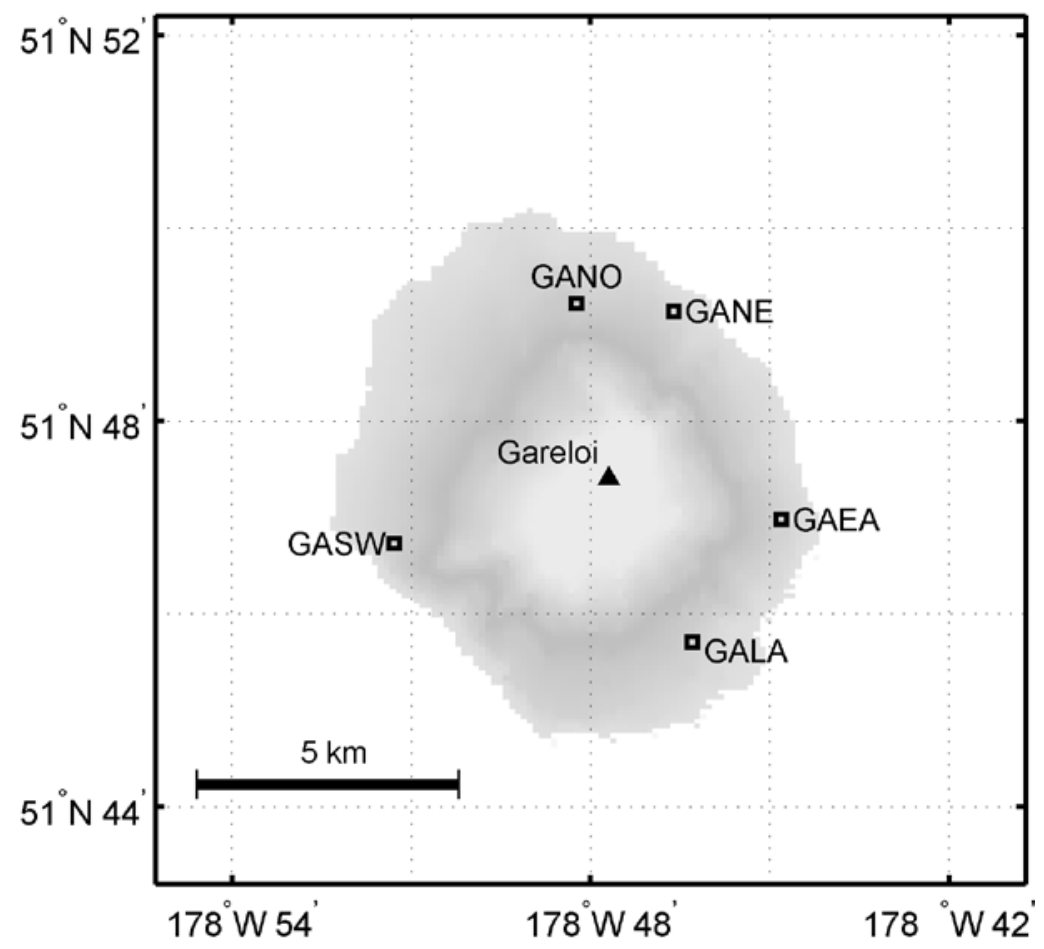

Figure C27. AVO seismograph stations near Mount Gareloi in 2009. Permanent stations are shown by open squares. Closed triangles show volcanic centers.

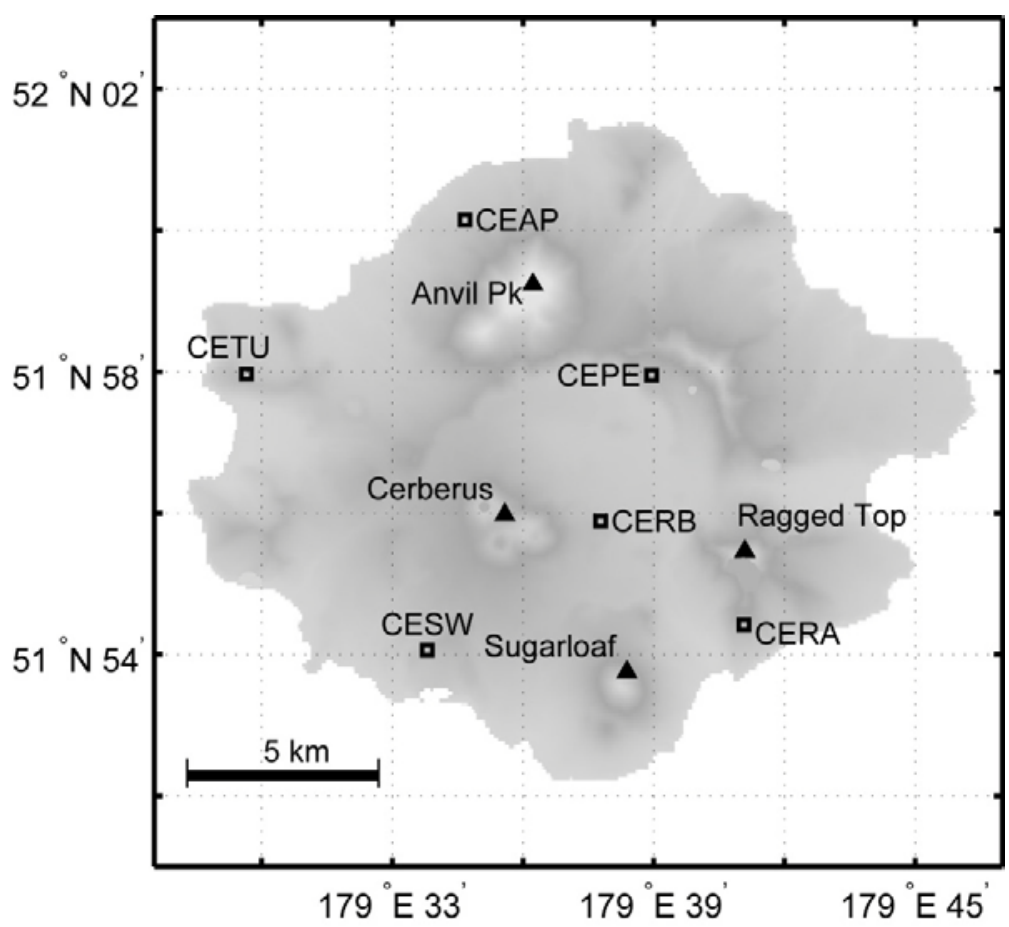

Figure C28. AVO seismograph stations on Semisopochnoi Island in 2009. Permanent stations are shown by open squares. Closed triangles show volcanic centers. 


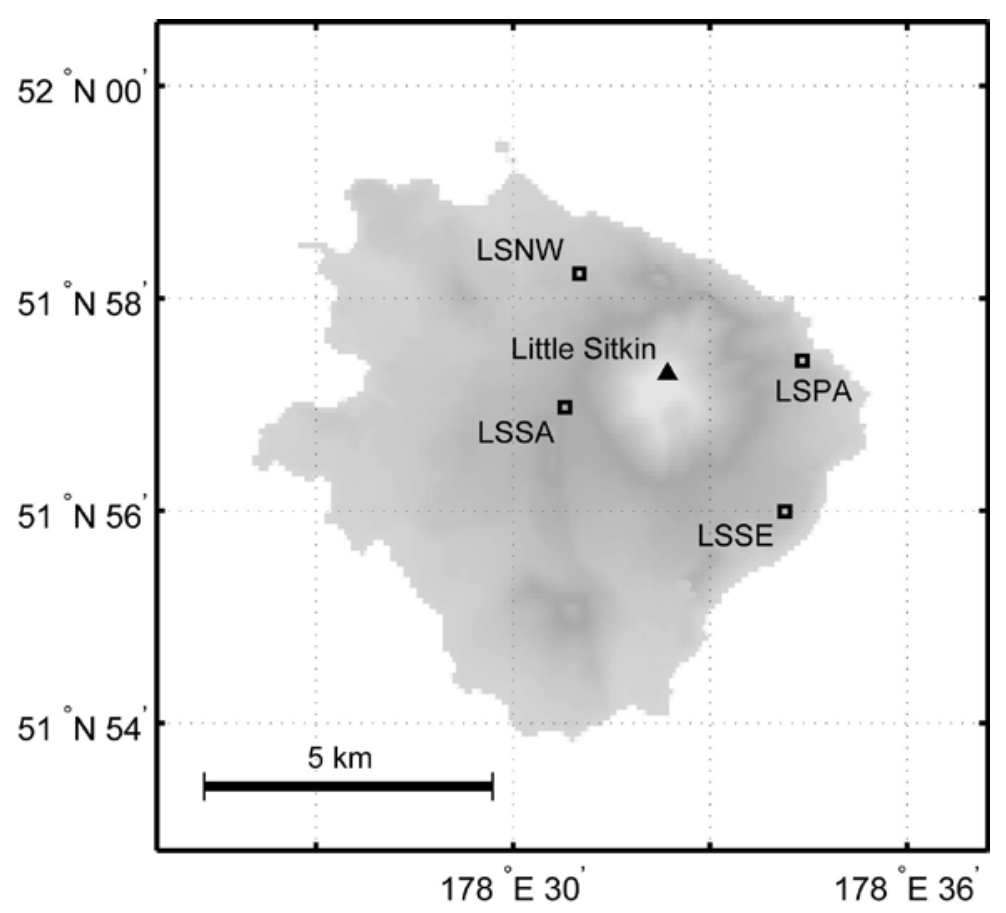

Figure C29. AVO seismograph stations on Little Sitkin Island in 2009. Seismograph station AMKA is not shown and is located $82 \mathrm{~km}$ south-southwest of Little Sitkin Volcano. Permanent stations are shown by open squares. Closed triangles show volcanic centers. 
66 Catalog of Earthquake Hypocenters at Alaskan Volcanoes: January 1 through December 31, 2009

This page left intentionally blank. 


\section{Appendix D. Operational Status for Alaska Volcano Observatory Stations in 2009.}

A solid bar indicates periods of time a station was operational based on station use plots and weekly checks. Dashed vertical lines show the beginning/end of each month.

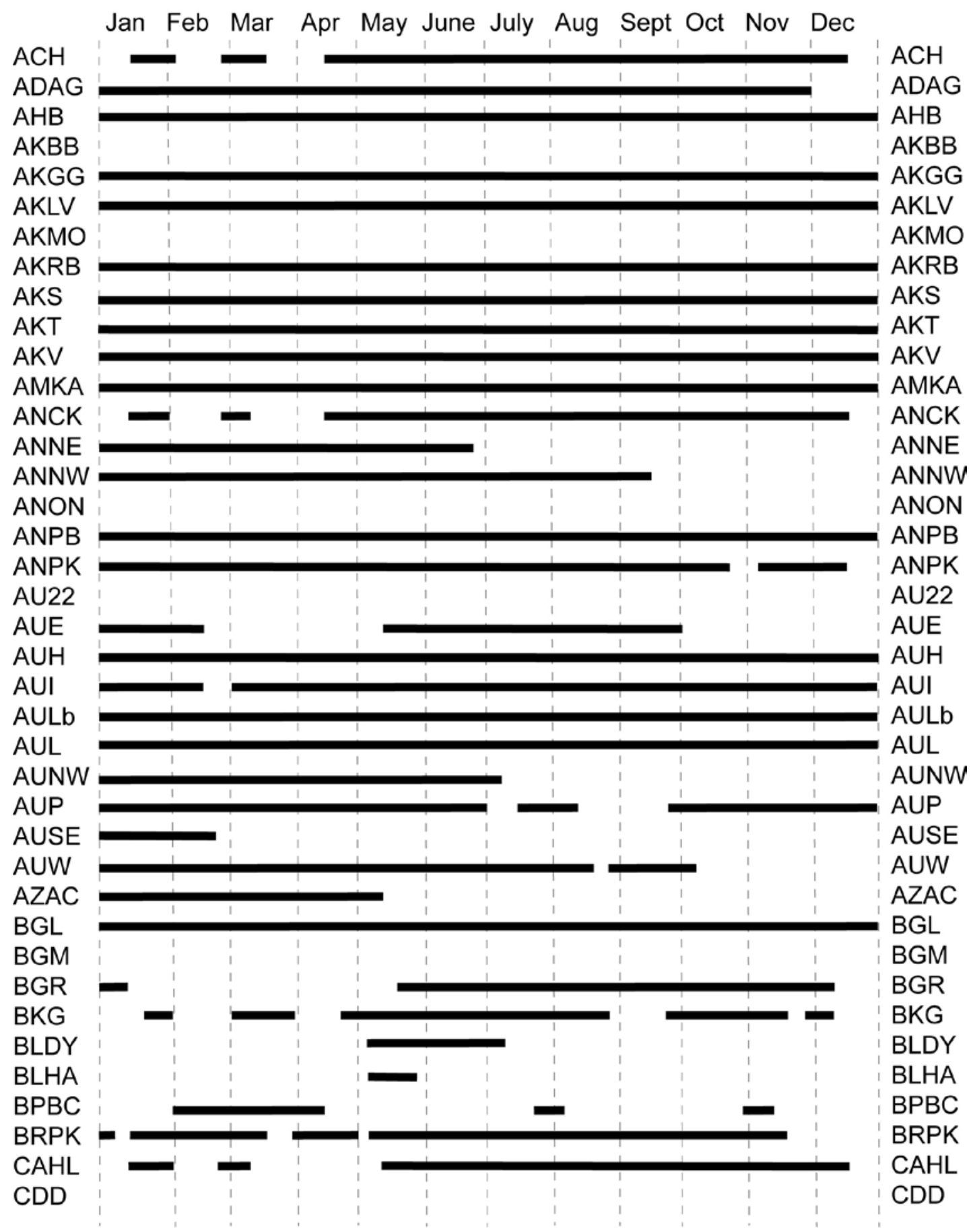




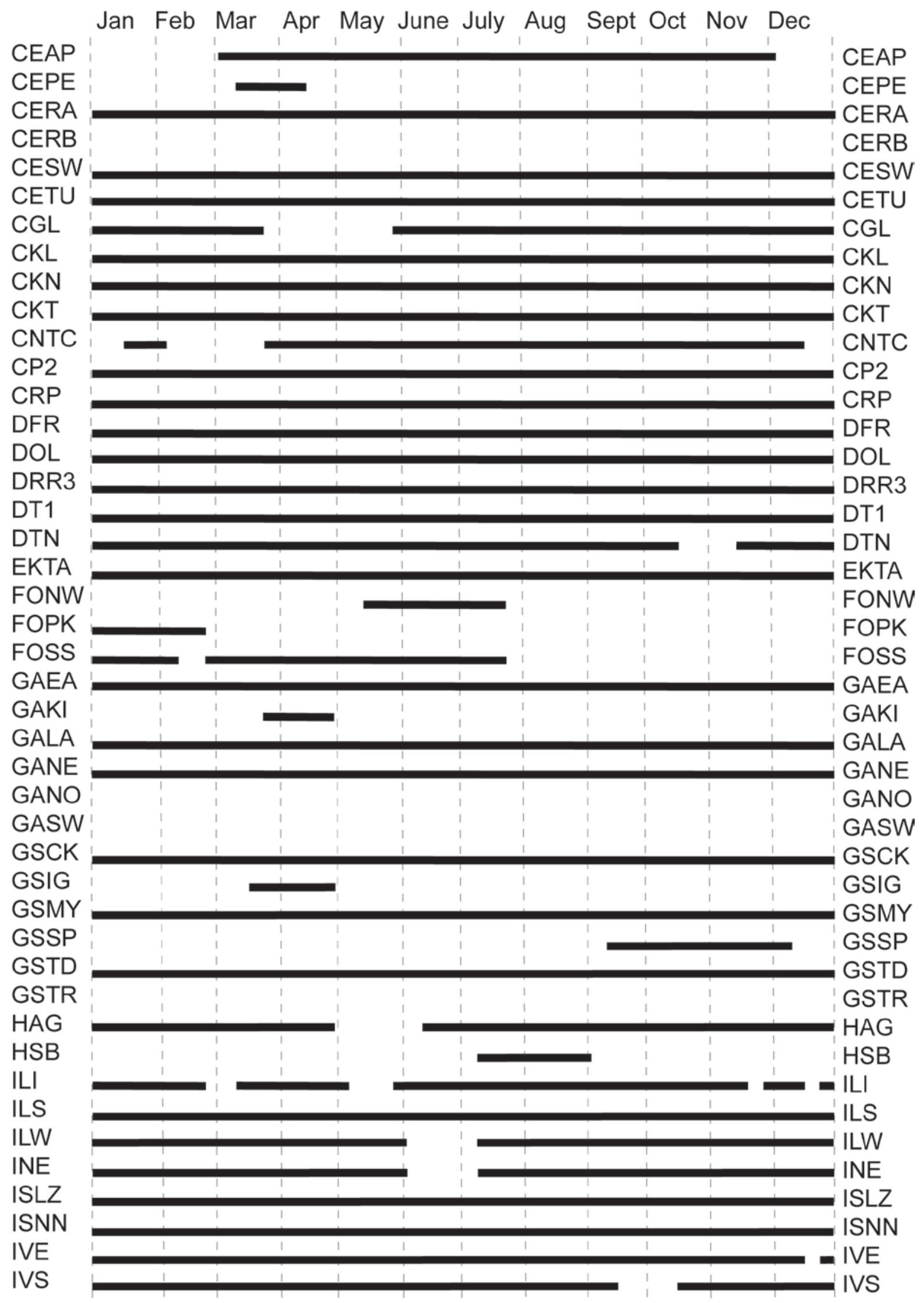




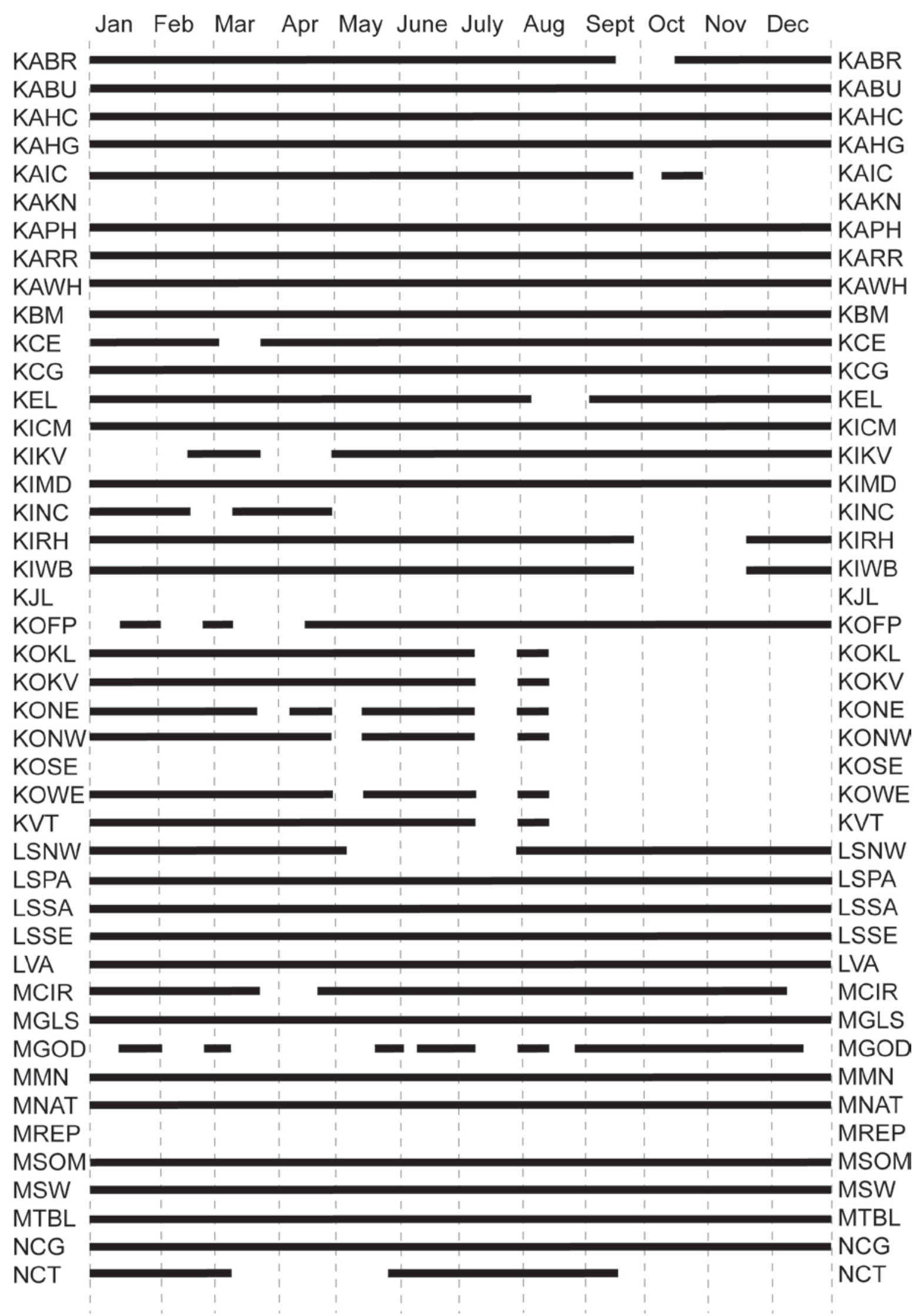




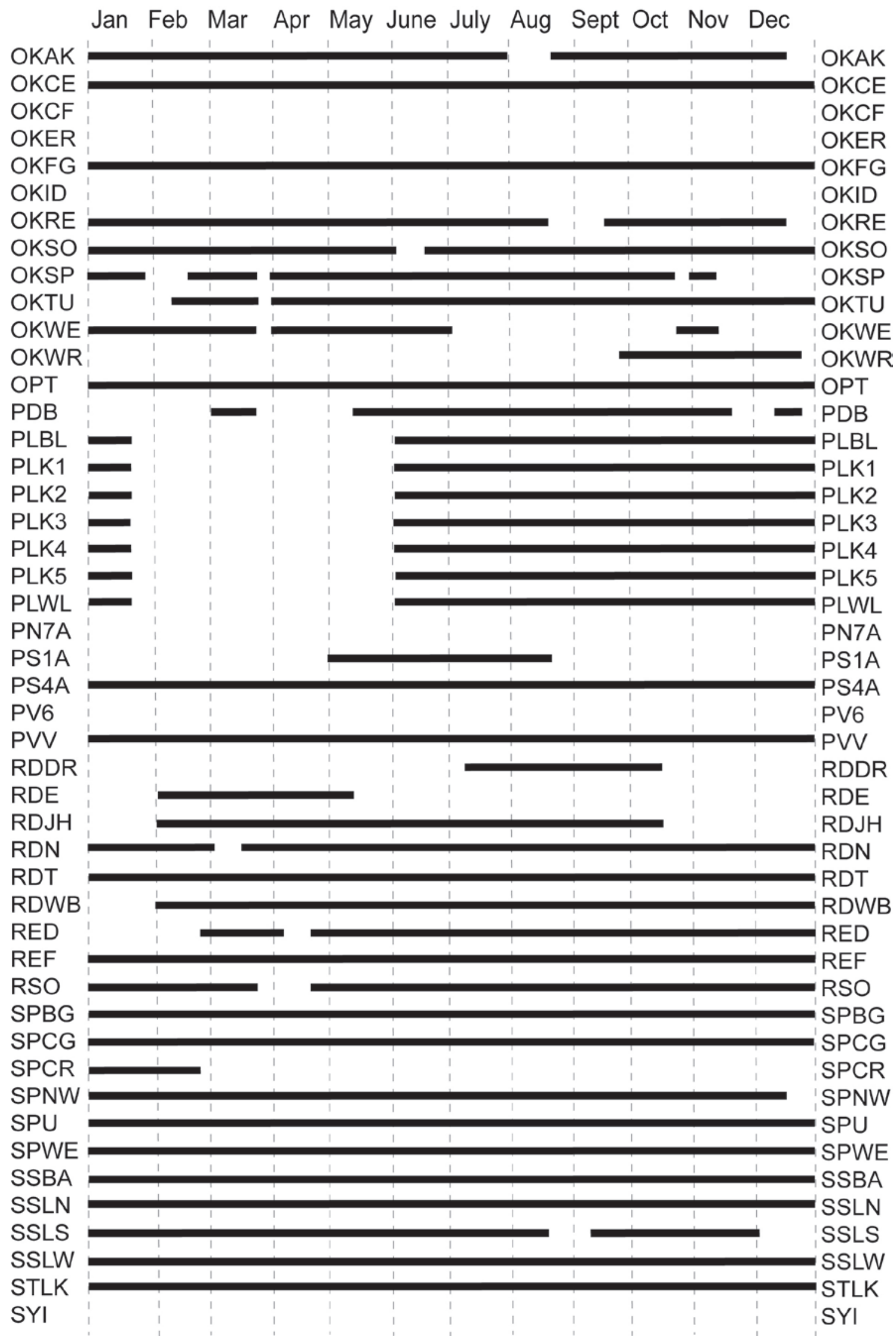




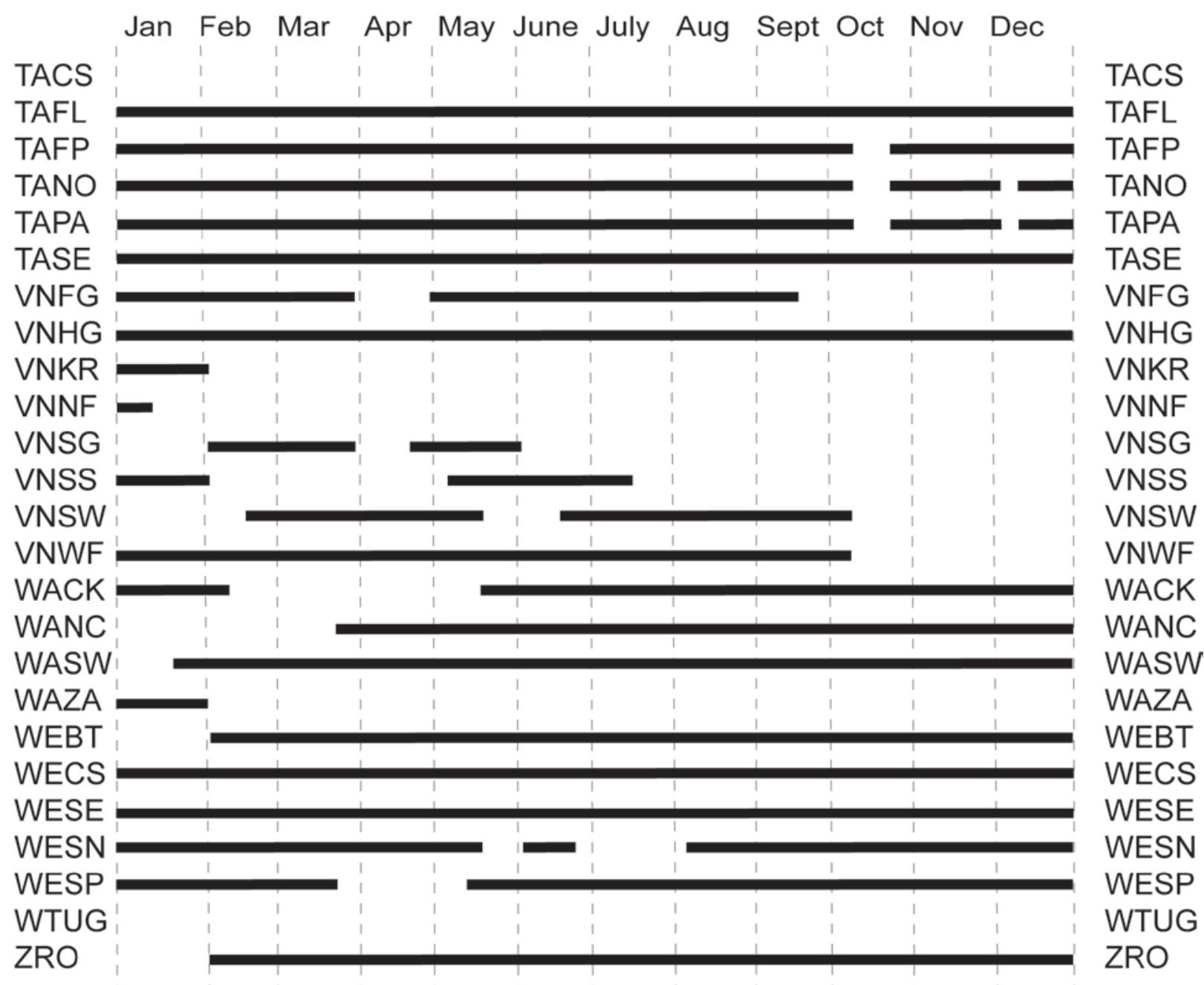


72 Catalog of Earthquake Hypocenters at Alaskan Volcanoes: January 1 through December 31, 2009

This page left intentionally blank. 


\section{Appendix E. Seismic Velocity Models Used in Locating the Earthquakes in 2009.}

Following the name of each velocity model is a list of volcano subnetworks for which the model is used. Depths are referenced to sea level, with negative values reflecting height above sea level.

Cylindrical Model Parameters (Latitude and Longitude are the center of the model).

$\begin{array}{lccccc}\text { Velocity Model } & \begin{array}{c}\text { Latitude } \\ \left({ }^{\circ} \mathbf{N}\right)\end{array} & \begin{array}{c}\text { Longitude } \\ \left({ }^{\circ} \mathbf{E}\right)\end{array} & \begin{array}{c}\text { Radius } \\ (\mathbf{k m})\end{array} & \begin{array}{c}\text { Top } \\ (\mathbf{k m})\end{array} & \begin{array}{c}\text { Bottom } \\ (\mathbf{k m})\end{array} \\ \text { Spurr } & 61.60 & -152.40 & 20 & -3 & 50 \\ \text { Spurr } & 61.47 & -152.33 & 20 & -3 & 50 \\ \text { Spurr } & 61.33 & -152.25 & 20 & -3 & 50 \\ \text { Spurr } & 61.17 & -152.35 & 20 & -3 & 50 \\ \text { Spurr } & 61.00 & -152.45 & 20 & -3 & 50 \\ \text { Redoubt } & 60.83 & -152.55 & 20 & -3 & 50 \\ \text { Redoubt } & 60.66 & -152.66 & 20 & -3 & 50 \\ \text { Redoubt } & 60.49 & -152.75 & 20 & -3 & 50 \\ \text { Redoubt } & 60.34 & -152.86 & 20 & -3 & 50 \\ \text { Iliamna } & 60.03 & -153.09 & 20 & -3 & 50 \\ \text { Augustine } & 59.36 & -153.42 & 20 & -3 & 50 \\ \text { Katmai } & 58.17 & -155.35 & 20 & -3 & 50 \\ \text { Katmai } & 58.29 & -154.86 & 20 & -3 & 50 \\ \text { Katmai } & 58.35 & -155.09 & 20 & -3 & 50 \\ \text { Katmai } & 58.43 & -154.38 & 20 & -3 & 50 \\ \text { Veniaminof } & 56.18 & -159.38 & 30 & -3 & 50 \\ \text { Cold Bay } & 55.42 & -161.89 & 20 & -3 & 50 \\ \text { Cold Bay } & 55.18 & -162.27 & 20 & -3 & 50 \\ \text { Cold Bay } & 54.76 & -163.97 & 30 & -3 & 50 \\ \text { Westdahl } & 54.52 & -164.65 & 20 & -3 & 50 \\ \text { Akutan } & 54.15 & -165.97 & 20 & -3 & 50 \\ \text { Okmok } & 53.40 & -176.13 & 20 & -3 & 50 \\ \text { Andreanof } & 52.08 & -176.13 & 20 & -3 & 50 \\ \text { Andreanof } & 51.93 & -176.75 & 20 & -3 & 50 \\ \text { Andreanof } & 51.92 & -177.17 & 20 & -3 & 50 \\ \text { Tanaga } & 51.89 & -178.15 & 20 & -3 & 50\end{array}$


74 Catalog of Earthquake Hypocenters at Alaskan Volcanoes: January 1 through December 31, 2008

Akutan Velocity Model (Power and others, 1996).

$\begin{array}{cccc}\text { Layer number } & \mathbf{V p}(\mathbf{k m} / \mathbf{s e c}) & \text { Top of layer }(\mathbf{k m}) & \mathbf{V p} / \mathbf{v s} \\ 1 & 2.30+0.37 \mathrm{~km} / \mathrm{sec} \text { for each km of depth } & -3.0 & 1.80 \\ 2 & 6.30 & 7.0 & 1.80\end{array}$

Andreanof Velocity Model (Toth and Kisslinger, 1984).

$\begin{array}{cccc}\text { Layer number } & \mathbf{V p}(\mathbf{k m} / \mathbf{s e c}) & \text { Top of layer } \mathbf{( k m )} & \mathbf{V p} / \mathbf{N s} \\ 1 & 3.50 & -3.0 & 1.73 \\ 2 & 3.88 & -2.8 & 1.73 \\ 3 & 4.25 & -2.6 & 1.73 \\ 4 & 4.62 & -2.4 & 1.73 \\ 5 & 5.00 & -2.2 & 1.73 \\ 6 & 5.50 & -2.0 & 1.73 \\ 7 & 5.62 & -1.0 & 1.73 \\ 8 & 5.74 & 0.0 & 1.73 \\ 9 & 5.86 & 1.0 & 1.73 \\ 10 & 5.98 & 2.0 & 1.73 \\ 11 & 6.10 & 3.0 & 1.73 \\ 12 & 6.60 & 4.0 & 1.73 \\ 13 & 6.68 & 5.0 & 1.73 \\ 14 & 6.80 & 8.0 & 1.73 \\ 15 & 6.92 & 11.0 & 1.73 \\ 16 & 7.04 & 14.0 & 1.73 \\ 17 & 7.16 & 17.0 & 1.73 \\ 18 & 7.28 & 20.0 & 1.73 \\ 19 & 7.85 & 23.0 & 1.73 \\ 20 & 8.05 & 37.0 & 1.73\end{array}$

Augustine Velocity Model (Power, 1988).

$\begin{array}{cccc}\text { Layer number } & \mathbf{V} \mathbf{p}(\mathbf{k m} / \mathbf{s e c}) & \text { Top of layer }(\mathbf{k m}) & \mathbf{V p} / \mathbf{V s} \\ 1 & 2.3 & -3.0 & 1.80 \\ 2 & 2.6 & -0.7 & 1.80 \\ 3 & 3.4 & 0.0 & 1.80 \\ 4 & 5.1 & 1.0 & 1.80 \\ 5 & 6.3 & 9.0 & 1.78 \\ 6 & 8.0 & 44.0 & 1.78\end{array}$


Cold Bay Velocity Model (McNutt and Jacob, 1986).

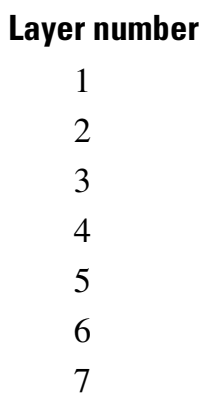

$\mathbf{V p}(\mathbf{k m} / \mathbf{s e c})$
3.05
3.44
5.56
6.06
6.72
7.61
7.90

Top of layer ( $k m)$

$-3.00$

0.00

1.79

3.65

10.18

22.63

38.51
$\mathbf{V p} / \mathbf{s}$

1.78

1.78

1.78

1.78

1.78

1.78

1.78

Iliamna Velocity Model (Roman and others, 2001).

Layer number
\[ \begin{array}{c}1 \\ 2 \\ 3 \\ 4 \\ 5 \\ 6\end{array} \]

$\mathbf{V p}(\mathbf{k m} / \mathbf{s e c})$
4.8
6.1
6.2
6.3
6.4
7.1

Top of layer $(\mathbf{k m})$

$\mathbf{V p} / \mathbf{N s}$

$-3.0$

1.78

1.78

$-1.6$

1.78

1.7

1.78

3.1

1.78

16.5

1.78

Katmai Velocity Model (Searcy, 2003).

$\begin{array}{cc}\text { Layer number } & \mathbf{V} \mathbf{p}(\mathbf{k m} / \mathbf{s e c}) \\ 1 & 5.05 \\ 2 & 5.10 \\ 3 & 5.41 \\ 4 & 5.49 \\ 5 & 5.65 \\ 6 & 5.67 \\ 7 & 5.69 \\ 8 & 5.76 \\ 9 & 5.80 \\ 10 & 6.00 \\ 11 & 6.04 \\ 12 & 6.08 \\ 13 & 6.30 \\ 14 & 6.73 \\ 15 & 7.54 \\ 16 & 7.78\end{array}$

Top of layer $(\mathbf{k m})$
-3.0
1.0
2.0
3.0
4.0
5.0
6.0
7.0
8.0
9.0
10.0
12.0
15.0
20.0
25.0
33.0

$\mathbf{V p} / \mathbf{V s}$

1.78

1.78

1.78

1.78

1.78

1.78

1.78

1.78

1.78

1.78

1.78

1.78

1.78

1.78

1.78

1.78 
76 Catalog of Earthquake Hypocenters at Alaskan Volcanoes: January 1 through December 31, 2008

Okmok Velocity Model (Masterlark and others, 2010).

$\begin{array}{cccc}\text { Layer number } & \mathbf{V} \mathbf{p}(\mathbf{k m} / \mathbf{s e c}) & \text { Top of layer }(\mathbf{k m}) & \mathbf{V p} / \mathbf{V s} \\ 1 & 3.830 & -3.0 & 1.78 \\ 2 & 3.891 & 0.0 & 1.78 \\ 3 & 5.084 & 1.0 & 1.78 \\ 4 & 5.187 & 2.0 & 1.78 \\ 5 & 5.470 & 3.0 & 1.78 \\ 6 & 6.185 & 4.0 & 1.78 \\ 7 & 6.191 & 10.0 & 1.78 \\ 8 & 6.454 & 12.0 & 1.78 \\ 9 & 6.896 & 16.0 & 1.78 \\ 10 & 7.414 & 20.0 & 1.78\end{array}$

Redoubt Velocity Model (Lahr and others, 1994).

$\begin{array}{cccc}\text { Layer number } & \mathbf{V} \mathbf{p}(\mathbf{k m} / \mathbf{s e c}) & \text { Top of layer }(\mathbf{k m}) & \mathbf{V p} / \mathbf{V s} \\ 1 & 2.90 & -3.0 & 1.80 \\ 2 & 5.10 & -1.7 & 1.80 \\ 3 & 6.40 & 1.5 & 1.72 \\ 4 & 7.00 & 17.0 & 1.78\end{array}$

Spurr Velocity Model (Jolly and others, 1994).

$\begin{array}{cccc}\text { Layer number } & \mathbf{V} \mathbf{p}(\mathbf{k m} / \mathbf{s e c}) & \text { Top of layer }(\mathbf{k m}) & \mathbf{V p} / \mathbf{N s} \\ 1 & 5.1 & -3.00 & 1.81 \\ 2 & 5.5 & -2.00 & 1.81 \\ 3 & 6.3 & 5.25 & 1.74 \\ 4 & 7.2 & 27.25 & 1.78\end{array}$

Tanaga Velocity Model (Power, written commun., 2005).

$\begin{array}{cccc}\text { Layer number } & \mathbf{V p}(\mathbf{k m} / \mathbf{s e c}) & \text { Top of layer }(\mathbf{k m}) & \mathbf{V p} / \mathbf{V s} \\ 1 & 4.0 & -3.0 & 1.78 \\ 2 & 4.5 & -1.2 & 1.78 \\ 3 & 5.0 & 0.0 & 1.78 \\ 4 & 5.6 & 4.0 & 1.78 \\ 5 & 6.9 & 10.0 & 1.78 \\ 6 & 7.2 & 15.0 & 1.78 \\ 7 & 7.8 & 20.0 & 1.78 \\ 8 & 8.1 & 33.0 & 1.78\end{array}$


Veniaminof Velocity Model (Sánchez, 2005).

$\begin{array}{cccc}\text { Layer number } & \mathbf{V p}(\mathbf{k m} / \mathbf{s e c}) & \text { Top of layer }(\mathbf{k m}) & \mathbf{V p} / \mathbf{N s} \\ 1 & 4.82 & -3.0 & 1.73 \\ 2 & 5.23 & 4.0 & 1.88 \\ 3 & 5.23 & 10.0 & 1.38 \\ 4 & 6.49 & 15.0 & 1.65 \\ 5 & 6.52 & 20.0 & 1.51 \\ 6 & 8.18 & 25.0 & 1.89 \\ 7 & 8.21 & 33.0 & 1.90 \\ 8 & 8.21 & 47.0 & 1.80 \\ 9 & 8.30 & 65.0 & 1.78\end{array}$

Westdahl Velocity Model (Dixon and others, 2005).

Layer number
\[ 1 \]
2
3
4
5
6
7
8

$\mathbf{V p}(\mathbf{k m} / \mathbf{s e c})$
3.03
3.18
5.03
5.70
6.30
6.82
7.17
8.16

Top of layer $(\mathbf{k m})$

$\mathbf{V p} / \mathbf{s}$

$-3.0$

1.71

1.71

1.71

1.71

1.71

1.71

1.71

1.71

Regional Velocity Model (Fogleman and others, 1993).

Layer number
1
2
3
4
5
6
7
8
9

$\mathbf{V p}(\mathbf{k m} / \mathbf{s e c})$
5.3
5.6
6.2
6.9
7.4
7.7
7.9
8.1
8.3

Top of layer $(\mathbf{k m})$

$\mathbf{V p} / \mathbf{N s}$

$-3.0$

1.78

1.78

10.0

1.78

15.0

1.78

20.0

1.78

35.0

1.78

33.0

1.78

47.0

1.78

1.78 
78 Catalog of Earthquake Hypocenters at Alaskan Volcanoes: January 1 through December 31, 2008

This page left intentionally blank. 


\section{Appendix F. Location of Volcanic Zones Modeled Using Multiple Cylinders.}

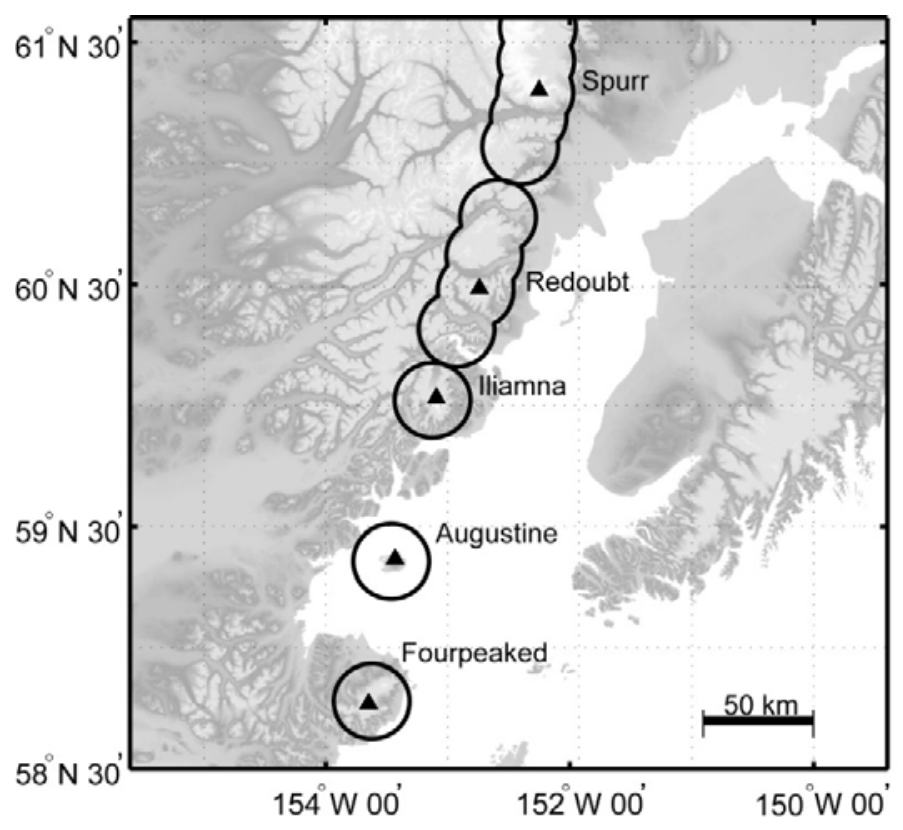

Figure F1. Volcanic zones for the Cook Inlet Volcanoes. Five overlapping cylinders model the Spurr volcanic zone. Four overlapping cylinders model the Redoubt volcanic zone. Single cylinders model the lliamna, Augustine, and Fourpeaked volcanic zones.

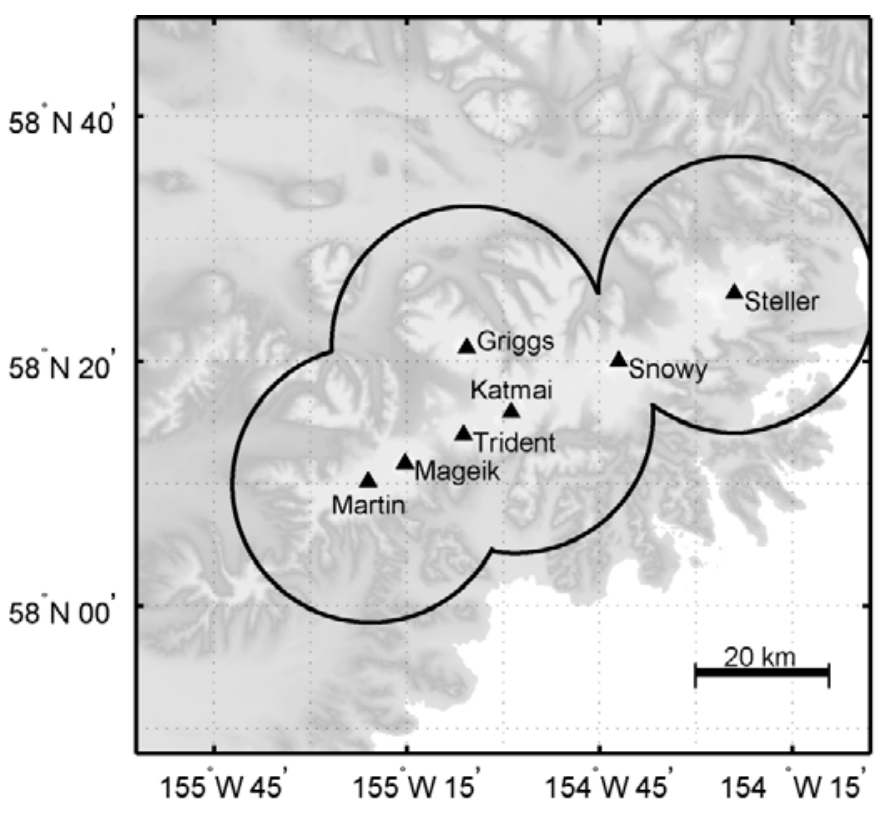

Figure F2. Volcanic zone for the Katmai volcanic cluster. The volcanic zone is modeled using four overlapping cylinders centered on Mount Martin, Mount Katmai, Mount Griggs, and Mount Steller. 


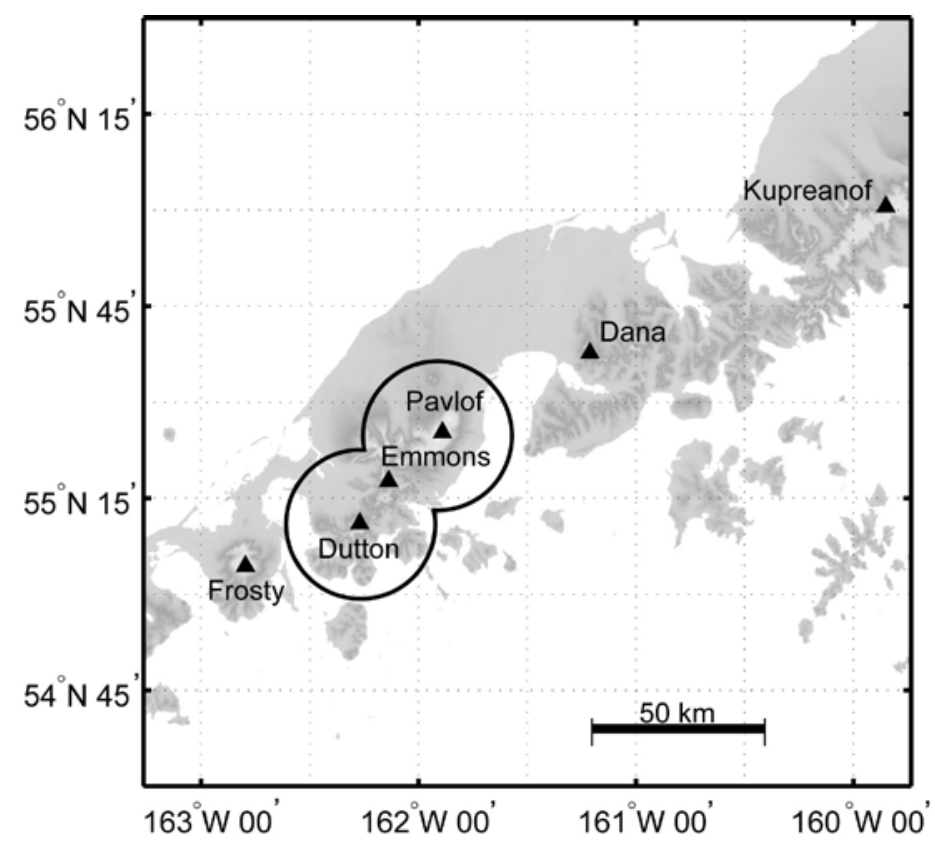

Figure F3. Volcanic zones for Pavlof Volcano and Mount Dutton. The volcanic zone is modeled using two overlapping cylinders centered on Mount Dutton and Pavlof Volcano.

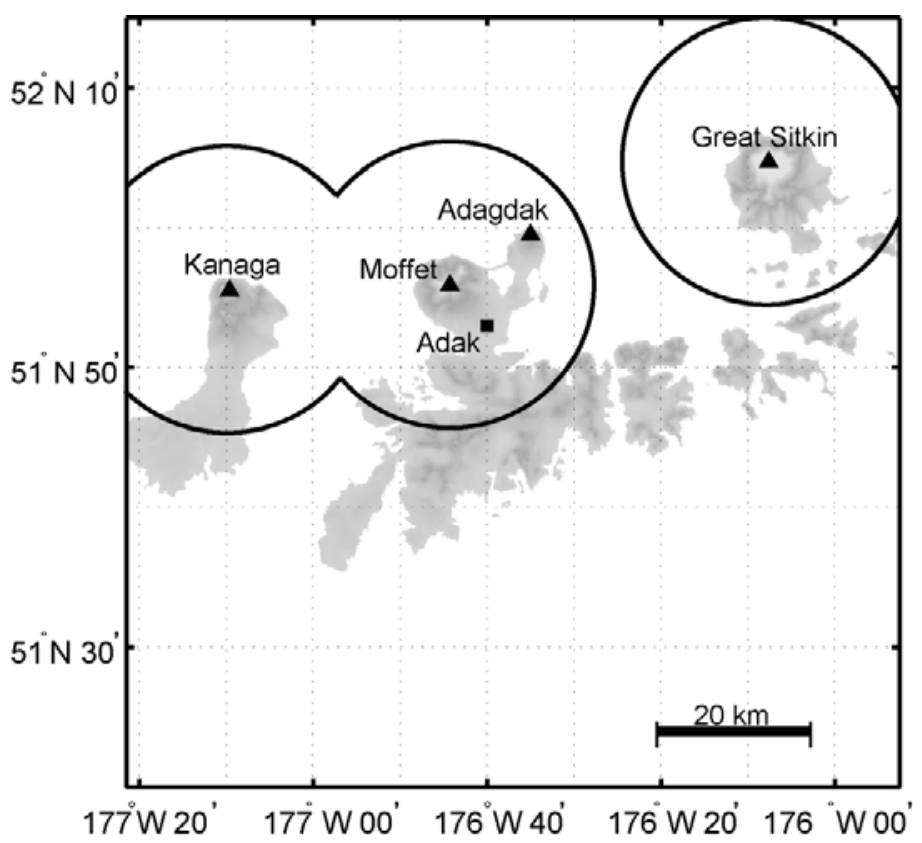

Figure F4. Volcanic zones in the Adak region. The volcanic zones are modeled using cylinders centered on Kanaga Volcano, Mount Moffett, and Great Sitkin Volcano. 


\section{Appendix G. Previous Alaska Volcano Observatory Earthquake Catalogs.}

Earthquake catalogs for 1989-present available from the U.S. Geological Survey.

1989-90: Power, J.A., March, G.D., Lahr, J.C., Jolly, A.D., and Cruse, G.R., 1993, Catalog of earthquake hypocenters at Redoubt Volcano and Mount Spurr, Alaska: October 12, 1989 - December 31, 1990: U.S. Geological Survey Open-File Report 93-685-A, 57 p.

1991-93: Jolly, A.D., Power, J.A., Stihler, S.D., Rao, L.N., Davidson, G., Paskievitch, J., Estes, S., and Lahr, J.C., 1996, Catalog of earthquake hypocenters for Augustine, Redoubt, Iliamna, and Mount Spurr Volcanoes, Alaska: January 1, 1991 - December 31, 1993: U.S. Geological Survey OpenFile Report 96-70, 90 p.

1994-99: Jolly, A.D., Stihler, S.D., Power, J.A., Lahr, J.C., Paskievitch, J., Tytgat, G., Estes, S., Lockhart, A.B., Moran, S.C., McNutt, S.R., and Hammond, W.R., 2001, Catalog of earthquake hypocenters at Alaskan Volcanoes: January 1, 1994 - December 31, 1999: U.S. Geological Survey Open-File Report 01-189, 202 p. (Also available at http://geopubs.wr.usgs.gov/open-file/of01-189/.)

2000-01: Dixon, J.P, Stihler, S.D., Power, J.A., Tytgat, G., Estes, S., Moran, S.C., Paskievitch, J., and McNutt, S.R., 2002, Catalog of Earthquake Hypocenters at Alaska Volcanoes: January 1, 2000 December 31, 2001: U.S. Geological Survey Open-File Report 02-342, 56 p.

(Also available at http://geopubs.wr.usgs.gov/open-file/of02-342/.)

2002: Dixon, J.P., Stihler, S.D., Power, J.A., Tytgat, G., Moran, S.C., Sánchez, J.J., Estes, S., McNutt, S.R., and Paskievitch, J., 2003, Catalog of Earthquake Hypocenters at Alaska Volcanoes: January 1 - December 31, 2002: U.S. Geological Survey Open-File Report 03-267, 58 p.

(Also available at http://geopubs.wr.usgs.gov/open-file/of03-267/.)

2003: Dixon, J.P., Stihler, S.D., Power, J.A., Tytgat, G., Moran, S.C., Sánchez, J.J., Estes, S., McNutt, S.R., and Paskievitch, J., 2004, Catalog of Earthquake Hypocenters at Alaska Volcanoes: January 1 - December 31, 2003: U.S. Geological Survey Open-File Report 2004-1234, 59 p.

(Also available at http://pubs.usgs.gov/of/2004/1234/.)

2004: Dixon, J.P., Stihler, S.D., Power, J.A., Tytgat, G., Estes, S., Prejean, S., Sánchez, J.J., Sanches, R., McNutt, S.R., and Paskievitch, J., 2005, Catalog of Earthquake Hypocenters at Alaskan Volcanoes: January 1 through December 31, 2004: U.S. Geological Survey Open-File Report 2005-1312, 74 p. (Also available at http://pubs.usgs.gov/of/2005/1312/.)

2005: Dixon, J.P., Stihler, S.D., Power, J.A., Tytgat, G., Estes, S., and McNutt, S.R., 2007, Catalog of Earthquake Hypocenters at Alaskan Volcanoes: January 1 through December 31, 2005: U.S. Geological Survey Open-File Report 2007-1264, 78 p. (Also available at http://pubs.usgs.gov/of/2006/1264/.)

2006: Dixon, J.P., Stihler, S.D., Power, J.A., and Searcy, Cheryl, 2008, Catalog of earthquake hypocenters at Alaskan Volcanoes: January 1 through December 31, 2006: U.S. Geological Survey Data Series 326, 78 p. (Also available at http://pubs.usgs.gov/ds/326/pdf/ds326.pdf.)

2007: Dixon, J.P., Stihler, S.D., and Power, J.A., and Searcy, Cheryl, 2008, Catalog of earthquake hypocenters at Alaskan Volcanoes: January 1 through December 31, 2007: U.S. Geological Survey Data Series 367, 82 p. (Also available at http://pubs.usgs.gov/ds/367/pdf/ds367.pdf.) 
82 Catalog of Earthquake Hypocenters at Alaskan Volcanoes: January 1 through December 31, 2009

2008: Dixon, J.P., and Stihler, S.D, 2009, Catalog of earthquake hypocenters at Alaskan Volcanoes: January 1 through December 31, 2008: U.S. Geological Survey Data Series 467, 88 p. (Also available at http://pubs.usgs.gov/ds/467/pdf/ds467.pdf.) 


\section{Appendix H. Selected Papers Published in 2009 Using Data Provided by Alaska Volcano Observatory.}

Caplan-Auerbach, J., Bellesiles, A., and Fernandes, J.K., 2009, Estimates of eruption velocity and plume height from infrasonic recordings of the 2006 eruption of Augustine Volcano, Alaska: Journal of Volcanology and Geothermal Research, v. 189, p. 12-18, doi:10.1016/j.jvolgeores.2009.10.002, http://www.sciencedirect.com/science/article/B6VCS-4XJ17NF1/2/d6da07097cdde73f705d91c330d016e2.

Dixon, J.P., and Power, J.A., 2009, The January 2006 volcanic-tectonic earthquake swarm at Mount Martin, Alaska, in Haeussler, P.J., and Galloway, J.P., eds., Studies by the U.S. Geological Survey in Alaska, 2007: U.S. Geological Survey Professional Paper 1760-D, 17 p. (Also available at http://pubs.usgs.gov/pp/1760/d/.)

Larsen, J., Neal, C., Webley, P., Freymueller, J., Haney, M., McNutt, S., Schneider, D., Prejean, S., Schaefer, J., and Wessels, R., 2009, Eruption of Alaska volcano breaks historic pattern: Eos, Transactions, American Geophysical Union, v. 90, n. 20, p. 173-174, doi:10.1029/2009EO200001, accessed August 13, 2010, at http://www.agu.org/pubs/crossref/2009/2009EO200001.shtml.

Statz-Boyer, P., Thurber, C., Pesicek, J., Prejean, S., 2009, High-precision relocation of earthquakes at Iliamna Volcano, Alaska: Journal of Volcanology and Geothermal Research, v. 184, p. 323-332, doi: 10.1016/j.jvolgeores.2009.04.016, accessed August 13, 2010, at http://dx.doi.org/10.1016/j.jvolgeores.2009.04.016. 
84 Catalog of Earthquake Hypocenters at Alaskan Volcanoes: January 1 through December 31, 2008

This page left intentionally blank. 
Publishing support provided by the U.S. Geological Survey Publishing Network, Tacoma Publishing Service Center

For more information concerning the research in this report, contact the Director, Alaska Science Center

U.S. Geological Survey

4210 University Dr.

Anchorage, Alaska 99508-4650

http://alaska.usgs.gov 


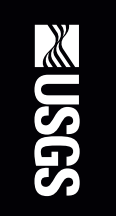

뭉.

음

웅

胥

1

O

$\frac{20}{8}$

음

西

흘

흐ำ

종

?

寄

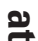

2

읏

$\delta$

음

옹

c

ํㅡㄹ

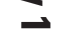

릉

뭉

릉

목

$\omega$

응

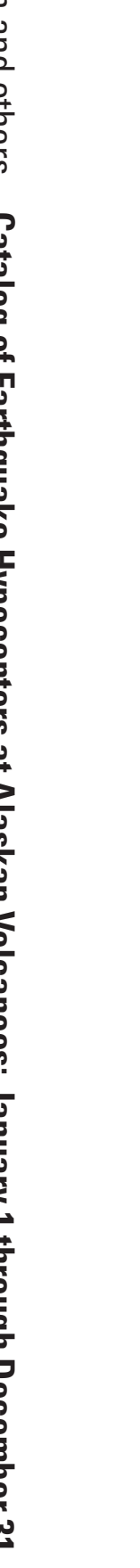

I

密

w

蛋.

ज్త 